ORP-56290

Revision 0

\title{
Final Report - Glass Formulation Development and Testing for DWPF High Al2O3 HLW Sludges, VSL-10R1670-1, Rev. 0, dated 12/20/10
}

Prepared for the U.S. Department of Energy

Assistant Secretary for Environmental Management

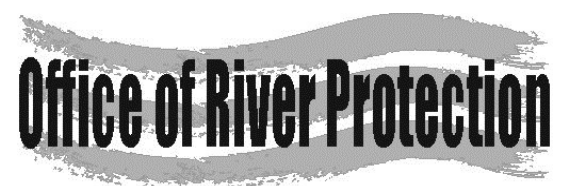

P.O. Box 450

Richland, Washington 99352 
ORP-56290

Revision 0

\section{Final Report - Glass Formulation Development and Testing for DWPF High Al2O3 HLW Sludges, VSL-10R1670-1, Rev. 0, dated $12 / 20 / 10$}

A. A. Kruger

Department of Energy - Office of River Protection

I. L. Pegg

The Catholic University of America

W. K. Kot

The Catholic University of America
H. Gan

The Catholic University of America

K. S. Matlack

The Catholic University of America

Date Published

June 2013

Prepared for the U.S. Department of Energy

Assistant Secretary for Environmental Management

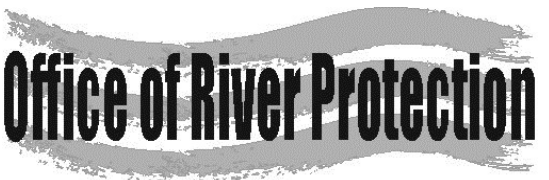

P.O. Box 450

Richland, Washington 99352

\section{APPROVED}

By Shauna Adams at 9:31 am, Nov 13, 2013

Release Approval

Date 
ORP-56290

Revision 0

TRADEMARK DISCLAIMER

Reference herein to any specific commercial product, process, or service by tradename, trademark, manufacturer, or otherwise, does not necessarily constitute or imply its endorsement, recommendation, or favoring by the United States Government or any agency thereof or its contractors or subcontractors.

This report has been reproduced from the best available copy.

Printed in the United States of America 
VSL-10R1670-1

\title{
Final Report
}

\section{Glass Formulation Development and Testing for DWPF High- $\mathrm{Al}_{2} \mathrm{O}_{3} \mathrm{HLW}$ Sludges}

\author{
prepared by
}

Keith S. Matlack, Wing K. Kot, Hao Gan, and Ian L. Pegg

Vitreous State Laboratory

The Catholic University of America

Washington, DC 20064

for

EnergySolutions, Federal EPC, Inc.

Columbia, MD

and

Department of Energy

Office of River Protection

Richland, WA 99352

and

Savannah River Remediation, LLC

Aiken, SC 29808

September 30, 2010

Rev. 0, 12/20/10 
The Catholic University of America Vitreous State Laboratory
Document Tirle:

Document Number and Revision:

Issue Date:

Performing Organization: Vitreous State Laboratory, The Catholic University of America

Test Plan:
Glass Formulation Development and Testing for DWPF High$\mathrm{Al}_{2} \mathrm{O}_{3} \mathrm{HLW}$ Sludges

VSL-10R1670-1, Rev. 0

$12 / 20 / 10$

Glass Formulation Development and Testing for DWPF High$\mathrm{Al}_{2} \mathrm{O}_{3}$ HLW Sludges, VSL-10T1670-1, Rev. 0

This report describes the results of testing specified by the above Test Plan. The work was performed in compliance with the quality assurance requirements specified in the Test Plan. Results required by the Test Plan are reported. The test results and this report have been reviewed for correctness, technical adequacy, completeness, and accuracy.

I.L. Pegg: $\quad($ Len

VSL Program Director/Primcppal Investigator

Date: $12 / 20 / 10$

I. Joseph: fronoccnt foschb Date: $12 / 20 / 10$ 


\section{TABLE OF CONTENTS}

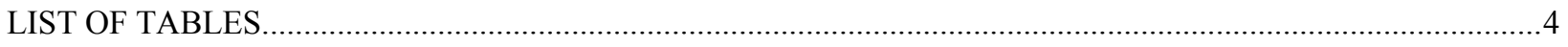

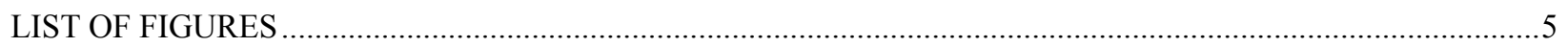

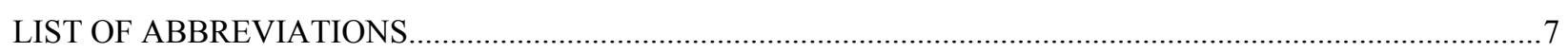

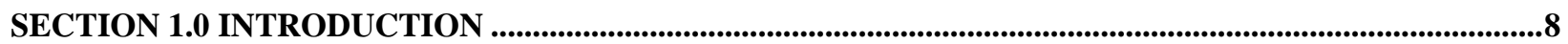

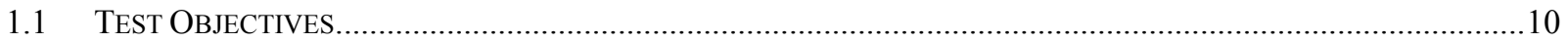

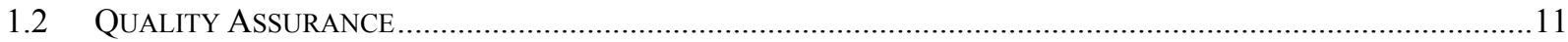

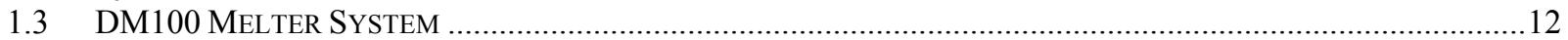

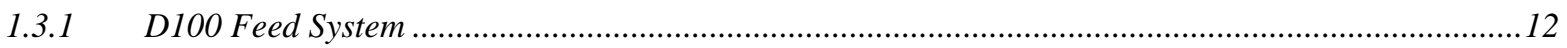

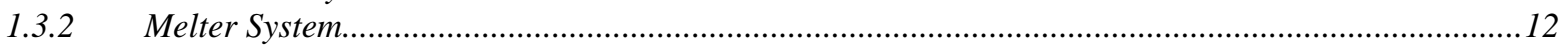

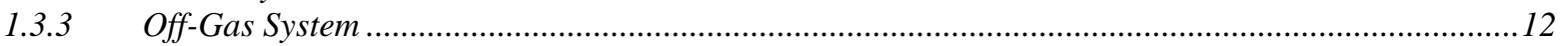

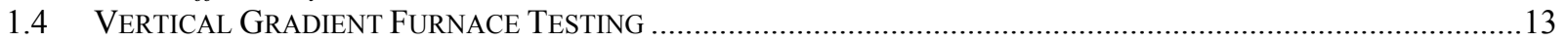

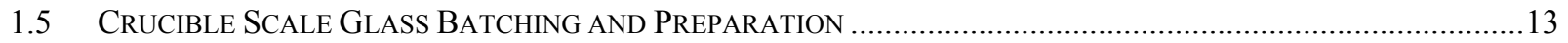

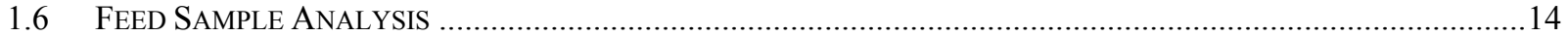

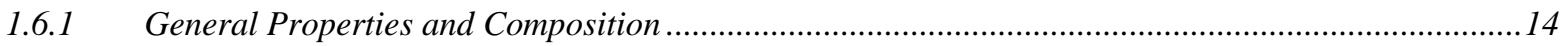

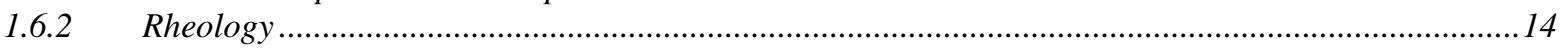

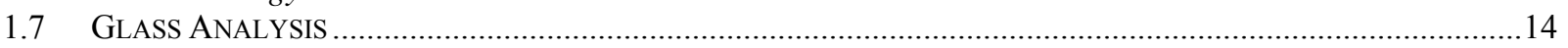

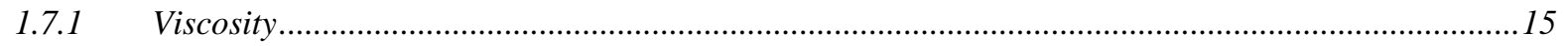

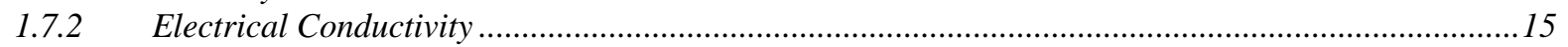

1.7.3 Product Consistency Test (PCT) ……………..............................................................................15

1.7.4 Heat Treatment and Characterization of Heat-Treated Glass.............................................................16

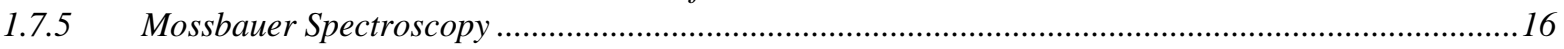

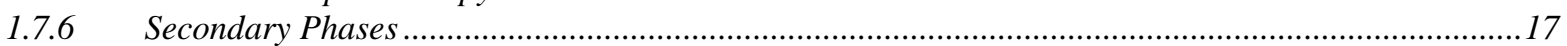

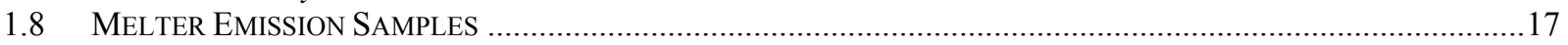

SECTION 2.0 WASTE COMPOSITION AND GLASS FORMULATION FOR SLUDGE BATCH 19...........18

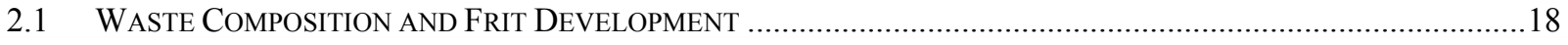

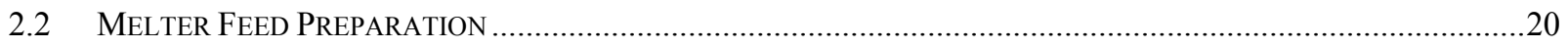

SECTION 3.0 VERTICAL GRADIENT FURNANCE MELT RATE TESTING ..............................................22

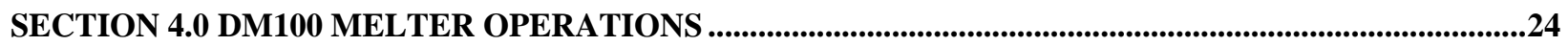

SECTION 5.0 FEED SAMPLE AND GLASS PRODUCT ANALYSIS...............................................................27

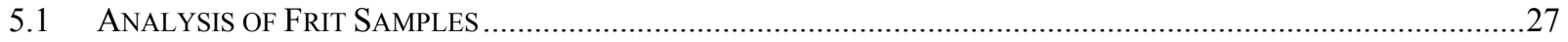

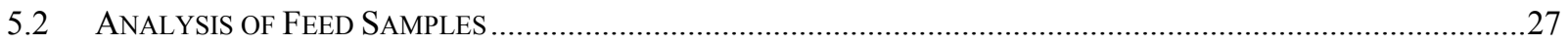

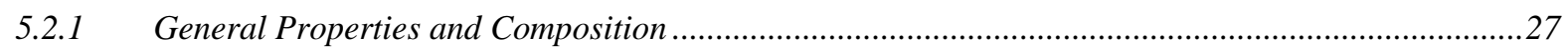

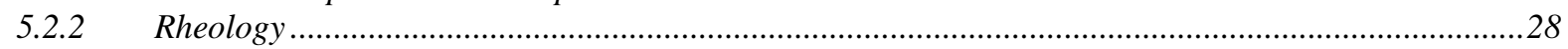

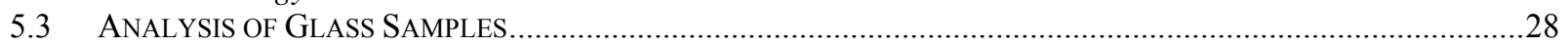

5.3.1 Compositional Analysis of Discharge Glasses ..............................................................................28

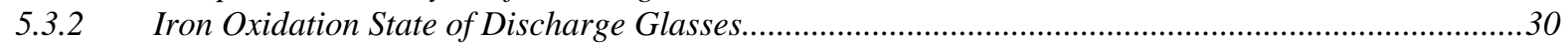

5.3.3 Chemical Durability of Discharge Glasses ............................................................................................31

5.3.4 Secondary Phase and Porosity Determination of Discharge Glasses ..................................................31

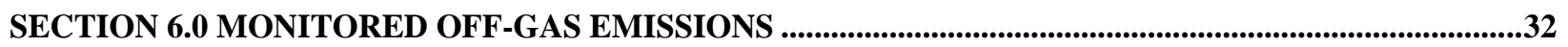

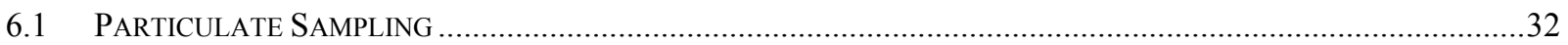

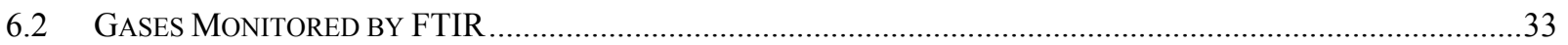

SECTION 7.0 SUMMARY AND CONCLUSIONS ............................................................................................35

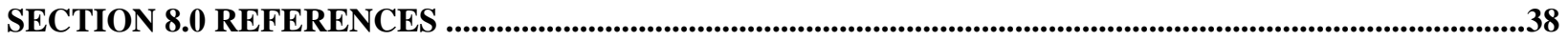




\section{List of Tables}

Table 2.1 Projected Compositions (wt $\%$ ) of the SRS High Aluminum-Based Sludge and the $\quad$ T-1 HLW Simulant.

Table 2.2 Compositions (wt \%) of the Glass Frits Formulated for the HLW Simulant. $\quad$ T-2

Table 2.3 Composition (wt\%) of the HLW Glasses Prepared with Glass Frit VS1. T-3

Table 2.4 Composition (wt\%) of the HLW Glasses Prepared with Glass Frit VS2. T-4

Table 2.5 Composition (wt\%) of the HLW Glasses Prepared with Glass Frits VS3 and VS4. T-5

Table 2.6 Combinations of Glass Frits and Waste Loadings Tested. $\quad$ T-6

Table 2.7 Compositional Analysis of HLW Glass by XRF (wt\%). $\quad$ T-7

Table 2.8 Canister Centerline Cooling (CCC) Heat Treatment Schedule. $\quad$ T-10

Table 2.9 Characterization Data for the HLW Glasses Prepared with Glass Frit VS1. T-11

Table 2.10 Characterization Data for the HLW Glasses Prepared with Glass Frit VS2. T-12

Table 2.11 Characterization Data for the HLW Glasses Prepared with Glass Frits VS3 and VS4. T-13

Table 2.12 Recipe for Co-Precipitated SB19 Sludge Simulant [20]. $\quad$ T-14

Table 2.13 Analyses of the Co-Precipitated SB19 Sludge Simulant. $\quad$ T-15

Table 2.14 Analytical Data for SRAT Product. $\quad$ T-15

Table 2.15 Composition of the Direct-Hydroxide Simulant (Oxide Content = 136.52 g). T-16

$\begin{array}{llr}\text { Table 4.1 Summary of Results from DM100 Tests with SRS SB19 Simulant } & \text { T-17 }\end{array}$

Prepared by Harrell Industries.

Table 4.2 Summary of Results from DM100 Tests with SRS SB19 Simulant $\quad$ T-18

Table 4.3 Steady-State Production Rates Achieved on the DM100 Melter with Various $\quad$ T-19

Table 4.4 Summary of Measured DM100 Parameters for SRS SB19 Tests. $\quad$ T-20

Table 5.1 XRF and DCP Analyzed Compositions of Glass Frit Used for SRS DM100 Tests (wt\%). T-21

Table 5.2 Characteristics of Feed Samples Taken During DM100 Tests. T-22

Table 5.3 XRF Analyzed Compositions of Vitrified Melter Feed Samples Produced from $\quad$ T-22

Table 5.4 XRF Analyzed Compositions for Vitrified Melter Feed Samples Produced from $\quad$ T-23

Waste Simulant from NOAH (wt\%).

Table 5.5 Rheological Properties of Melter Feed Produced from Waste Simulated by T-24

Different Methods.

Table 5.6 List of Glass Discharged, Masses, and Analysis Performed During DM100 Tests $\quad$ T-25 with SRS SB19.

Table 5.7 XRF-Analyzed Compositions of Discharged Glass Samples from the DM100 Tests (wt\%). T-27

Table 5.8 XRF and DCP Analyzed Compositions of Glass Samples Collected During T-31 DM100 Tests (wt\%).

Table 5.9 Divalent Iron Measured by Mossbauer Spectroscopy on Glasses Discharged T-33 During DM100 Tests.

Table 5.10 PCT Results (ASTM C1285, 7-days at $90^{\circ} \mathrm{C}$, Stainless Steel Vessel; S/V=2000 m ${ }^{-1}$ ) T-34 for Melter Glasses.

Table 6.1 DM100 Melter Off-Gas Emission Results from Tests with SRS SB19 T-35 Simulant Prepared by Harrell Industries.

Table 6.2 DM100 Melter Off-Gas Emission Results from Tests with SRS SB19 $\quad$ T-37

Simulant Prepared by NOAH.

Table 6.3 Comparison of Particulate Carryover During Tests With and Without Bubbling. T-38

Table 6.4 Average Concentrations [ppmv] of Selected Species in Off-Gas Measured by FTIR $\quad$ T-39 Spectroscopy for SRS SB19 Tests. 


\section{List of Figures}

Figure 1.1 Schematic diagram of DuraMelter 100-BL vitrification system.

Figure 1.2.a Schematic diagram showing cross-section through the DM100-BL melter.

F-1

Figure 1.2.b Schematic diagram showing cross-section through the DM100-BL melter.

F-2

F-3

Figure 1.2.c Schematic diagram showing cross-section through the DM100-BL melter.

F-4

Figure 1.3 Schematic diagram of vertical gradient furnace (VGF) for feed conversion test.

Figure 1.4 Temperature gradient inside the loaded ceramic crucible of the Vertical Gradient Furnace (VGF).

Figure 3.1 Top views of the melter feed blends after VGF experiments (30 and 60 minutes) with VS3 frit and SB19 simulant.

Figure 3.2 Cross section views of the melter feed blends after VGF experiments (30 and 60 minutes) with VS3 frit and SB19 simulant.

Figure 4.1.a Glass production rates (hourly moving averages) for SRS SB19 Test 1.

Figure 4.1.b Glass production rates (hourly moving averages) for SRS SB19 Test 2.

Figure 4.1.c Glass production rates (hourly moving averages) for SRS SB19 Tests 3.

Figure 4.1.d Glass production rates (hourly moving averages) for SRS SB19 Tests 4 and 5.

Figure 4.2.a Glass pool bubbling rate for SRS Batch 19 Test 1.

Figure 4.2.b Glass pool bubbling rates for SRS Batch 19 Test 3.

Figure 4.2.c Glass pool bubbling rates for SRS Batch 19 Test 4.

Figure 4.3.a Glass temperatures (hourly averages) during SRS SB19 Test 1.

Figure 4.3.b Glass temperatures (hourly averages) during SRS SB19 Test 2.

Figure 4.3.c Glass temperatures (hourly averages) during SRS SB19 Test 3.

Figure 4.3.d Glass temperatures (hourly averages) during SRS SB19 Tests 4 and 5.

Figure 4.4.a Plenum temperatures (hourly averages) during SRS SB19 Test 1.

Figure 4.4.b Plenum temperatures (hourly averages) during SRS SB19 Test 2.

Figure 4.4.c Plenum temperatures (hourly averages) during SRS SB19 Test 3.

Figure 4.4.d Plenum temperatures (hourly averages) during SRS SB19 Tests 4 and 5.

Figure 4.5.a Electrode temperatures and power (hourly averages) during SRS SB19 Test 1.

Figure 4.5.b Electrode temperatures and power (hourly averages) during SRS SB19 Test 2.

Figure 4.5.c Electrode temperatures and power (hourly averages) during SRS SB19 Test 3.

Figure 4.5.d Electrode temperatures and power (hourly averages) during SRS SB19

Tests 4 and 5.

Figure 4.6.a Melt pool resistance and total electrode power during SRS SB19 Test 1.

Figure 4.6.b Melt pool resistance and total electrode power during SRS SB19 Test 2.

Figure 4.6.c Melt pool resistance and total electrode power during SRS SB19 Test 3.

Figure 4.6.d Melt pool resistance and total electrode power during SRS SB19 Tests 4 and 5.

Figure 5.1 Viscosity vs. shear rate of melter feed samples containing waste simulated by different methods.

Figure 5.2.a Silicon and aluminum oxide concentrations determined by XRF from glass produced during DM100 SRS SB19 Tests.

Figure 5.2.b Iron and sodium oxide concentrations determined by XRF from glass produced during DM100 SRS SB19 Tests.

Figure 5.2.c Calcium and titanium oxide concentrations determined by XRF from glass produced $\quad$ F-35 during DM100 SRS SB19 Tests.

Figure 5.2.d Chromium and manganese oxide concentrations determined by XRF from glass produced during DM100 SRS SB19 Tests.

Figure 5.2.e Nickel and zirconium oxide concentrations determined by XRF from glass produced during DM100 SRS SB19 Tests.

Figure 5.2.f Potassium and magnesium oxide concentrations determined by XRF from glass produced during DM100 SRS SB19 Tests.

Figure 5.2.g Cerium and sulfur oxide concentrations determined by XRF from glass produced during DM100 SRS SB19 Tests. 
The Catholic University of America Vitreous State Laboratory

Figure 5.2.h Bismuth and phosphorus oxide concentrations determined by XRF from glass produced $\quad$ F-40 during DM100 SRS SB19 Tests.

Figure 5.3 Measured glass divalent iron concentrations during DM100 tests with SRS SB19 waste simulant produced by Harrell Industries. Test conducted with argon bubbling.

Figure 5.4 Measured glass divalent iron concentrations during DM100 tests with SRS SB19 waste simulant produced by NOAH. Test conducted without bubbling. 


\section{List of Abbreviations}

$\begin{array}{ll}\text { ADS } & \text { Air Displacement Slurry } \\ \text { ANL-LRM Argonne National Laboratory - Low Activity Reference Material } \\ \text { AOD } & \text { Air Operated Diaphragm } \\ \text { CCC } & \text { Canister Center Line Cooling } \\ \text { DCP-AES } & \text { Direct Current Plasma Atomic Emission Spectroscopy } \\ \text { DF } & \text { Decontamination Factor } \\ \text { DM } & \text { DuraMelter } \\ \text { DOE } & \text { Department of Energy } \\ \text { DRE } & \text { Destruction \& Removal Efficiency } \\ \text { DWPF } & \text { Defense Waste Processing Facility } \\ \text { EA } & \text { Environmental Assessment } \\ \text { EPA } & \text { Environmental Protection Agency } \\ \text { EDS } & \text { Energy Dispersive X-Ray Spectroscopy } \\ \text { FTIR } & \text { Fourier Transform Infrared Spectroscopy } \\ \text { GC } & \text { Gas Chromatography } \\ \text { HEPA } & \text { High-Efficiency Particulate Air Filter } \\ \text { HLW } & \text { High Level Waste } \\ \text { IC } & \text { Ion Chromatography } \\ \text { LAW } & \text { Low Activity Waste } \\ \text { M } & \text { Molarity } \\ \text { N } & \text { Normality } \\ \text { NIST } & \text { National Institute of Standards and Technology } \\ \text { NQA } & \text { Nuclear Quality Assurance } \\ \text { ORP } & \text { Office of River Protection } \\ \text { PCCS } & \text { Product Composition Control System } \\ \text { PCT } & \text { Product Consistency Test } \\ \text { QA } & \text { Quality Assurance } \\ \text { QAPP } & \text { Quality Assurance Project Plan } \\ \text { QC } & \text { Quality Control } \\ \text { SB } & \text { Sludge Batch } \\ \text { SEM } & \text { Scanning Electron Microscopy } \\ \text { SIPP } & \text { Semi Integrated Pilot Plant } \\ \text { SME } & \text { Slurry Mix Evaporator } \\ \text { SRAT } & \text { Sludge Receipt and Adjustment Tank } \\ \text { SRM } & \text { Standard Reference Material } \\ \text { SRNL } & \text { Savannah River National Laboratory } \\ \text { SRR } & \text { Savannah River Remediation } \\ \text { SRS } & \text { Savannah River Site } \\ \text { TCLP } & \text { Toxicity Characteristic Leaching Procedure } \\ \text { VGF } & \text { Vertical Gradient Furnace } \\ \text { VSL } & \text { Vitreous State Laboratory } \\ \text { WTP } & \text { Hanford Tank Waste Treatment and Immobilization Plant } \\ \text { WVDP } & \text { West Valley Demonstration Project } \\ \text { XRD } & \text { X-ray Diffraction } \\ \text { XRF } & \text { X-Ray Fluorescence } \\ & \end{array}$




\section{SECTION 1.0 INTRODUCTION}

Implementation of aluminum (Al)-dissolution for future processing of selected sludge batches is being considered at the Savannah River Site (SRS). In this process, some of the aluminum is dissolved from the high-level waste (HLW) solids. The resulting reduction in HLW sludge mass after Al-dissolution is expected to decrease the number of canisters of HLW glass to be produced at the Defense Waste Processing Facility (DWPF). The obvious benefits of reduced sludge mass, however, need to be weighed against various technical issues associated with implementation of the process. These issues include the impacts of Al-dissolution on glass formulations and on glass production rates, both of which determine waste throughput at the DWPF. Al-dissolution was performed on Sludge Batch 5 (SB5) and Sludge Batch 6 (SB6) at SRS. For subsequent sludge batches, preliminary studies have been performed to evaluate the downstream impacts of Al-dissolution (see, for example, references [1-2]), with the results pointing to the need for a thorough cost-benefit analysis before a technically sound decision can be made concerning implementation of the process for all sludge batches.

Regardless of whether Al-dissolution will be implemented at SRS, the possibility of increasing waste loading through development of high $\mathrm{Al}_{2} \mathrm{O}_{3}$-based glass formulations warrants investigation. Increasing waste loading in HLW glass offers the potential for decreasing the amount of glass to be sent to the geologic repository. Frit development and optimization efforts at Savannah River National Laboratory (SRNL) have led to improvements in both waste loadings and waste throughput, while more recent efforts in glass formulation development have centered on waste streams with high aluminum concentrations [3]. Independent from the SRNL efforts, earlier technology development activities at the Vitreous State Laboratory (VSL) for the Office of River Protection (ORP) sought to maximize waste loadings and to determine the waste loading-limiting factors for several Hanford waste streams that were variously high in bismuth, chromium, aluminum, and aluminum plus sodium [4]. Glass formulations that meet all processing and product quality requirements for the Hanford Tank Waste Treatment and Immobilization Plant (WTP) were successfully developed for each of the waste streams, while achieving very high waste loadings. Processing of the glass formulations that were developed was also demonstrated in melter tests of various scales. The test results showed that, with the exception of the chromium-limited glass, for which the waste loading ( $40 \mathrm{wt} \%$ ) was decreased to $32.5 \mathrm{wt} \%$ in order to mitigate sulfate/chromate salt formation during processing, all of the highwaste-loading glasses could be processed without any significant operational problems. However, issues with slow melt rates were identified for some of the formulations. Subsequent work addressed enhancement of melt rates while maintaining high waste loadings for the high aluminum stream [5]. The results from small-scale melt rate screening tests and small-scale melter tests were confirmed in large-scale pilot melter tests on the DM1200 system at the VSL. The Hanford high-aluminum wastes have considerably higher aluminum contents than is the case for SRS HLW streams. Consequently, the experience and success at VSL in developing highwaste-loading glasses provide a valuable basis to improve waste loadings in HLW glass formulations for DWPF. 
The work described in this Final Report involves the development of HLW glass formulations for a DWPF waste sludge that is high in $\mathrm{Al}_{2} \mathrm{O}_{3}$ to achieve high waste loadings while meeting all measured relevant process and product performance criteria at DWPF. Since the cost and schedule for HLW processing are also dependent on glass production rate, it is important to ensure that the new glass formulations do not negatively affect the melt rate and waste throughput. Therefore, after a target glass composition with high waste loading was identified from the formulation work, melter tests were used to assess melt rate, cold cap behavior, and glass production rate for the target composition. Additionally, testing with a vertical gradient furnace (VGF) was used to evaluate the dependence of melt rate on waste loading for a selected glass-forming system (i.e., sludge waste coupled with glass frit). The information obtained from this work should provide useful input for cost-benefit analyses regarding the implementation of Al-dissolution at SRS.

In previous work performed to support the WTP, VSL has developed and tested glass formulations for WTP HLW waste compositions to provide data to meet the WTP contract requirements and to support system design activities [6, 7]. That work was based upon smallscale batch melts ("crucible melts") using waste simulants. Selected formulations have also been tested in small-scale, continuously fed, joule-heated melters (DM100) [8-10] and, ultimately, in the HLW DM1200 Pilot Melter [10-18]. Such melter tests provide information on key process factors such as feed processing behavior, dynamic effects during processing, secondary phase formation, processing rates, off-gas amounts and compositions, foaming control, etc., that cannot be reliably obtained from crucible melts. This sequential scale-up approach in the vitrification testing program ensures that maximum benefit is obtained from the more costly melter tests and that the most effective use is made of those resources. The present work employs a similar approach and strategy as was used in the vitrification development program to support the WTP. The melter tests in the present work were performed on the DM100 melter, which has been used in a large number of tests to support the WTP and a set of tests with SRS SB3 and SB4 simulants, and therefore allows comparison of the data from the current tests to those from previous tests. In addition, the DM100 melter provides a good compromise between scale of testing and cost.

This Final Report provides data and analyses for five DM100 melter tests with a SRS waste stream and optimized glass composition. The original scope of work gave direction for two of these tests [19]. The resulting Test Plan outlined the two tests processing a simulated SRS waste with and without bubbling [20]. Subsequently, funding was provided by Savannah River Remediation (SRR) to repeat the bubbling test using argon in place of air as the bubbling gas, as described in a second Test Plan [21]. This test was added to investigate any differences in processing and glass product characteristics in response to changing the bubbling gas from air, which has been used in previous melter tests to support WTP and tests with SRS SB3 and SB4 simulants, to argon, which is currently planned as the bubbling gas at DWPF. In addition, ORP elected to add two more tests with and without bubbling in order to evaluate the effect of different simulant preparation methods on feed processing characteristics [22]. Most of the melter test support work for WTP was conducted using simulants prepared by mixing a corresponding set of chemicals, referred to as the direct-hydroxide method. In contrast, simulants employed at SRS have used a co-precipitation process followed by simulation of the Sludge 
Receipt and Adjustment Tank (SRAT) and Slurry Mix Evaporator (SME) chemical processing cycles used for melter feed preparation at DWPF, which make their preparation much more time consuming and costly. Although the two processes generate simulants that have the same elemental compositions and produce the same glass composition when combined with the appropriate glass frit targeting the same waste loading, the resulting melter feeds may differ in other properties (such as $\mathrm{pH}$, particle size distribution, rheology, etc.) that have the potential to affect processing characteristics. Conducting these tests with the more fully simulated feed along with the chemical simulant using the direct hydroxide method permits the comparison of the production rate and feed processing characteristics of feeds based on the two simulants.

Previous tests for the WTP with simulants prepared using different methods showed feed processing rates that are comparable, with the direct hydroxide simulant processing at a rate slightly lower than that of the precipitated simulant [9]. The precipitated simulant processed at a glass production rate of $1183 \mathrm{~kg} /\left(\mathrm{m}^{2}\right.$.day $)$, the direct hydroxide simulant at a rate of 1117 $\mathrm{kg} /\left(\mathrm{m}^{2}\right.$.day), and a simulant with rheology adjusted to match that of the precipitated simulant at a rate of $1148 \mathrm{~kg} /\left(\mathrm{m}^{2}\right.$.day $)$,

\section{$1.1 \quad$ Test Objectives}

The principal objective of the work described in this Final Report is to develop and identify glass frit compositions for a specified DWPF high-aluminum based sludge waste stream that maximizes waste loading while maintaining high production rate for the waste composition provided by ORP/SRS. This was accomplished through a combination of crucible-scale, vertical gradient furnace, and confirmation tests on the DM100 melter system. The DM100-BL unit was selected for these tests. The DM100-BL was used for previous tests on HLW glass compositions [8-10] that were used to support subsequent tests on the HLW Pilot Melter [10-18]. It was also used to process compositions with waste loadings limited by aluminum, bismuth, and chromium $[4,5]$, to investigate the volatility of cesium and technetium during the vitrification of an HLW AZ-102 composition [23], to process glass formulations at compositional and property extremes $[24,25]$, and to investigate crystal settling on a composition that exhibited one percent crystals at $963^{\circ} \mathrm{C}$ (i.e., close to the WTP limit) [26]. The same melter was selected for the present tests in order to maintain comparisons between the previously collected data. The tests provide information on melter processing characteristics and off-gas data, including formation of secondary phases and partitioning.

Specific objectives for the melter tests are as follows:

- Determine maximum glass production rates without bubbling for a simulated SRS Sludge Batch 19 (SB19).

- Demonstrate a feed rate equivalent to $1125 \mathrm{~kg} / \mathrm{m}^{2} /$ day glass production using melt pool bubbling.

- Process a high waste loading glass composition with the simulated SRS SB19 waste and measure the quality of the glass product. 
- Determine the effect of argon as a bubbling gas on waste processing and the glass product including feed processing rate, glass redox, melter emissions, etc..

- Determine differences in feed processing and glass characteristics for SRS SB19 waste simulated by the co-precipitated and direct-hydroxide methods.

The above tests were proposed based on previous tests for WTP [9] in which there were few differences in the melter processing characteristics, such as processing rate and melter emissions, between precipitated and direct hydroxide simulants, even though there were differences in rheological properties. To the extent this similarity is found also for simulants for SRS HLW, the direct hydroxide methods may offer the potential for faster, simpler, and cheaper simulant production. There was no plan to match the yield stress and particle size of the direct hydroxide simulant to that of the precipitated simulant because that would have increased the preparation cost and complexity and defeated the purpose of the tests.

These objectives were addressed by first developing a series of glass frits and then conducting a crucible scale study to determine the waste loading achievable for the waste composition and to select the preferred frit. Waste loadings were increased until the limits of a glass property were exceeded experimentally. Glass properties for evaluation included: viscosity, electrical conductivity, crystallinity (including liquidus temperature and nepheline formation after canister centerline cooling (CCC) heat-treatment), gross glass phase separation, and the 7day Product Consistency Test (PCT, ASTM-1285) response. Glass property limits were based upon the constraints used for DWPF process control.

\subsection{Quality Assurance}

This work was conducted under a Nuclear Quality Assurance (NQA)-1 (2000 and 2004) and NQA-2a (1990) Part 2.7 based quality assurance program that is in place at the VSL. This program is supplemented by a Quality Assurance Project Plan for ORP work [27] that is conducted at VSL. Test and procedure requirements by which the testing activities are planned and controlled are also defined in this plan. The program is supported by VSL standard operating procedures that were used for this work [28]. In addition, the requirements of DOE/RW-0333P, Rev. 20 were applied to the following specific aspects of this work:

- Crucible melt preparation

- Analysis of crucible melt glasses

- PCT. 


\subsection{DM100 Melter System}

\subsubsection{D100 Feed System}

A schematic diagram of the DM100 vitrification system is shown in Figure 1.1. The melter feed is introduced in batches into a feed container that is mounted on a load cell for weight monitoring. The feed is stirred with a variable speed mixer and constantly recirculated except for periodic, momentary interruptions during which the weight is recorded. Feed is normally introduced into the melter via a system designed to mimic the pulsed operation of an Air Displacement Slurry (ADS) pump, which is the present WTP baseline; however, since an ADS pump is not employed at the DWPF, a peristaltic pump was used in these tests, which also facilitates observations of any differences in processing rates and feed behavior. In this system, a recirculation loop extends to the top of the melter where feed is diverted from the recirculation loop to the peristaltic pump and subsequently into the melter through a Teflon-lined feed line and water-cooled, vertical feed tube.

\subsubsection{Melter System}

Cross-sectional diagrams of the DM100-BL melter are shown in Figures 1.2.a-c. The DM100-BL unit is a ceramic refractory-lined melter fitted with five electrodes: two pairs of opposing Inconel 690 plate electrodes and a bottom electrode. Power can be supplied in either three-phase or single-phase configurations. All of the tests in the present work were performed with the upper and lower electrodes on each side connected and powered by a single-phase supply; the bottom electrode was not powered. Melt pool agitation is achieved by either a removable lance entering from the top of the melter or a permanent bubbler installed through the bottom electrode. In these tests the lance bubbler was used. The glass product is removed from the melter by means of an airlift discharge system. The melter has a melt surface area of $0.108 \mathrm{~m}^{2}$ and a variable glass inventory of between $110 \mathrm{~kg}$, when only the bottom pair of electrodes is used, and about $180 \mathrm{~kg}$ when both pairs of electrodes are used, which was the case in the present tests.

\subsubsection{Off-Gas System}

For operational simplicity, the DM100-BL is equipped with a dry off-gas treatment system involving gas filtration operations only. Exhaust gases leave the melter plenum through a film cooler device that minimizes the formation of solid deposits. The film-cooler air has constant flow rate and its temperature is thermostatically controlled. Consequently, under steady-state operating conditions, the exhaust gases passing through the transition line (between the melter and the first filtration device) can be sampled at constant temperature and airflow rate. The geometry of the transition line conforms to the requirements of the 40-CFR-60 air sampling techniques. Immediately downstream of the transition line are cyclonic filters followed by conventional pre-filters and HEPA filters. The temperature of the cyclonic filters is maintained above $150^{\circ} \mathrm{C}$ while the temperatures in the HEPAs are kept sufficiently high to prevent moisture 
condensation. The entire train of gas filtration operations is duplicated and each train is used alternately. An induced draft fan completes the system.

\subsection{Vertical Gradient Furnace Testing}

Figure 1.3 is a schematic diagram of the vertical gradient furnace (VGF) setup. This system has proved useful for melt rate screening of feed composition variations in previous work [5]. The temperature gradient inside the VGF is maintained by two separate sets of heating elements, both of which are arranged in cylindrical form and aligned along their axes. The inner heater is set at $1150^{\circ} \mathrm{C}$, which is the nominal temperature of the glass pool, and the ambient heater is set at $600^{\circ} \mathrm{C}$, which is similar to the plenum temperature. A ceramic crucible (about 4 inches tall) is used to hold the reacting melter feed. The temperature gradient in the loaded furnace is shown in Figure 1.4.

Feed samples (equivalent to about $20 \mathrm{~g}$ of glass) that have been dried at $150^{\circ} \mathrm{C}$ are placed inside the ceramic crucible, which already contains about $10 \mathrm{~g}$ of pre-melted glass of the same composition. Feed reactions under the controlled temperature gradient are allowed to continue for the designated test duration and then quenched by rapid cooling in air. The top surface and cross sections (by sectioning of the crucible) of the reacted feed are then inspected and photographed. Samples of the partially reacted feed are taken for further characterization by scanning electron microscopy (SEM)/energy dispersive x-ray spectroscopy (EDS), x-ray diffraction (XRD), and x-ray fluorescence spectroscopy (XRF). The composition of the feed is confirmed by XRF analysis of samples that are fused at $1150^{\circ} \mathrm{C}$. Results from these feed formulations are compared to results obtained from feed samples with known DM100 processing rates. These data provide a "calibration curve" that relates the VGF test results to processing rates obtained from melter tests on the DM100 [5].

\subsection{Crucible Scale Glass Batching and Preparation}

The glasses were prepared from reagent grade chemicals to produce a batch size of approximately $400 \mathrm{~g}$ according to VSL standard operating procedures. Crucible melts were prepared by melting the appropriate combination of well-mixed chemicals at $1150^{\circ} \mathrm{C}$ for 120 minutes in a platinum-gold crucible open to the air atmosphere in the furnace. Mixing of the melt was accomplished with a mechanical platinum/rhodium stirrer beginning 20 minutes after the start of melting and continuing for the next 90 minutes. During the last ten minutes of melting, stirring was stopped and the stirrer was raised above the melt so that glass from the stirrer could drain back into the crucible. The molten glass was poured at the end of 120 minutes of melting onto a graphite plate to cool, with the resulting glass collected and distributed for analyses.

Glass samples for redox measurements were prepared by melting slurry feeds in a closed crucible using the same procedure used by SRNL. For these tests, the ceramic crucibles were sealed with a nepheline gel (S Prime Mod from ZYP Coatings, Inc.) per that procedure. 


\subsection{Feed Sample Analysis}

\subsubsection{General Properties and Composition}

Feed samples were taken directly from the feed recirculation line during each melter test. Feed samples were characterized for density, $\mathrm{pH}$, water content, and glass yield. Feed sample composition was determined by first pouring the feed into a platinum/gold crucible and heating in a programmed furnace for drying and fusion to form a glass. The glass produced from this fusion was ground to less than 200 mesh and sealed in $20-\mathrm{ml}$ vials for subsequent analysis by $\mathrm{XRF}$, or by acid digestion followed by direct current plasma - atomic emission spectroscopy (DCP-AES) on the resulting solution.

\subsubsection{Rheology}

Samples of the melter feeds that were used for these tests were also subjected to rheological characterization. The results from rheological characterization of a variety of other melter feeds and waste simulants, as well as the effects of a range of test variables, are described in detail in a separate report [29]. Melter feeds were characterized using a Haake RS75 rheometer, which was equipped with either a Z40DIN or a FL22-SZ40 sensor. A typical set of measurements consists of identifying the flow characteristics of the slurry by measuring the shear stress on the slurry at controlled shear rates and temperatures. In these measurements, the shear rate values are preset and are increased stepwise from $0.01 \mathrm{~s}^{-1}$ to $200 \mathrm{~s}^{-1}\left(70 \mathrm{~s}^{-1}\right.$ for FL22-SZ40) with a sufficient delay (typically 15 to 30 seconds) between steps to ensure that the shear stress is allowed to fully relax and therefore is measured at equilibrium. This approach is somewhat different from the "flow curve" approach in which the shear rate is ramped up to some maximum value and then ramped back down to produce a hysteresis curve that is dependent on the selected ramp rate. The viscosity of the sample as a function of the shear rate is then calculated as the ratio of the shear stress to the shear rate. The yield stress data for the melter feeds were measured using a controlled-stress mode in which the torque on the rotor was slowly increased while the resulting deformation of the fluid was monitored. The discontinuity in the measured deformation-torque curve was identified as the yield stress. It should be noted that this direct measurement of the yield stress can be quite different from the value that is often reported as the yield stress, which is obtained by extrapolation of the shear stress-shear rate curve to zero shear rate [29]. From previous work [29], the differences in the relationship between shear stress and shear rate from the "flow curve" and steady state measurements are generally smaller at the higher shear rates. All of the measurements in this work were made at $25^{\circ} \mathrm{C}$; previous work [29], which examined a range of temperatures, showed a relatively weak effect of temperature.

\subsection{Glass Analysis}

The glass product is discharged from the melter into 5-gallon steel pails periodically using an air-lift system. The discharged product glass was sampled at the end of each test by removing sufficient glass from the top of the cans for compositional analysis and secondary phase determinations. In addition, the Product Consistency Test ( 7 days at $90^{\circ} \mathrm{C}$ ) was performed 
on samples of the glass product from the DM100 melter tests. Prior to those tests, the PCT was also performed on the crucible melt compositions that were selected for the melter tests to ensure their compliance with DWPF requirements. The formulated glasses were fabricated at VSL on a crucible scale (about 400 grams), with the resulting glass products divided into portions that were used for the various tests, including PCT (quenched and CCC), measurements of melt viscosity and electrical conductivity, and determination of crystallization upon heat treatment (both isothermal and CCC). All of these procedures are routinely conducted at VSL and, therefore, standard operating procedures (SOPs) are in place.

Sample preparation for chemical analysis typically involves size reduction and sieving. All samples were subjected to XRF to determine the concentration of all elements except boron and lithium. A series of National Institute of Standards and Technology (NIST) reference materials were used for confirmation of the XRF data. Boron and lithium were determined by total acid dissolution of ground glass samples in $\mathrm{HF} / \mathrm{HNO}_{3}$ and subjecting the resulting solutions to DCP-AES analysis.

\subsubsection{Viscosity}

The melt viscosity, $\eta$, is measured using a Brookfield viscometer. Measurements are performed in the temperature range of $950-1250^{\circ} \mathrm{C}$ and the data are interpolated to standard temperatures using the Vogel-Fulcher equation: $\ln \eta=\left[\mathrm{A} /\left(\mathrm{T}-\mathrm{T}_{\mathrm{o}}\right)\right]+\mathrm{B}$, where $\mathrm{A}, \mathrm{B}$, and $\mathrm{T}_{\mathrm{o}}$ are fitting parameters. The equipment is calibrated at room temperature using standard oils of known viscosity and then checked at $950-1250^{\circ} \mathrm{C}$ using a NIST standard reference glass (Standard Reference Material (SRM) 711). Both precision and accuracy of the viscosity measurements are estimated to be within \pm 15 relative $\%$.

\subsubsection{Electrical Conductivity}

The electrical conductivity, $\sigma$, of each glass melt is determined by measuring the resistance of the glass melts as a function of frequency using a calibrated platinum/rhodium electrode probe attached to a Hewlett-Packard model 4194A impedance analyzer. Measurements are performed over similar temperature ranges to those employed for the melt viscosity measurements. The results are analyzed to obtain the DC electrical conductivity. The electrical conductivity data are then interpolated to standard temperatures using the Vogel-Fulcher equation: $\ln \sigma=\left[\mathrm{A} /\left(\mathrm{T}-\mathrm{T}_{\mathrm{o}}\right)\right]+\mathrm{B}$, where $\mathrm{A}, \mathrm{B}$ and $\mathrm{T}_{\mathrm{o}}$ are fitting parameters. Estimated uncertainties in the electrical conductivity measurements are \pm 20 relative $\%$.

\subsubsection{Product Consistency Test (PCT)}

The product consistency test (PCT; ASTM C 1285) is used to evaluate the relative chemical durability of glasses by measuring the concentrations of the chemical species released from 100-200 mesh crushed glass $(75-149 \mu \mathrm{m})$ to the test solution (de-ionized water in this case). PCT tests were performed at $90^{\circ} \mathrm{C}$. The ratio of the glass surface area to the solution volume for 
this test is about $2000 \mathrm{~m}^{-1}$ (typically, $10 \mathrm{~g}$ of 100-200 mesh glass is immersed in $100 \mathrm{ml}$ deionized water). All tests are conducted in triplicate, in $304 \mathrm{~L}$ stainless steel vessels, and in parallel with a standard glass included in each test set. The internal standard is the Argonne National Laboratory - Low Activity Reference Material (ANL-LRM) reference glass [30] and/or the DWPF-Environmental Assessment (EA) glass [31], both of which have undergone roundrobin testing. The leachates are sampled at predetermined times, the first of which is seven days. One milliliter of sampled leachate is mixed with $20 \mathrm{ml}$ of $1 \mathrm{M} \mathrm{HNO}_{3}$ and the resulting solution is analyzed by DCP-AES; another $3 \mathrm{ml}$ of sampled leachate is used for $\mathrm{pH}$ measurement.

\subsubsection{Heat Treatment and Characterization of Heat-Treated Glass}

Glass samples (about 5 grams each) were heated in platinum, platinum-gold, or platinumrhodium crucibles $(5 \mathrm{ml})$ at a temperature of $1200^{\circ} \mathrm{C}$ for 1 hour in order to destroy pre-existing nuclei. This was followed by heat treatment under the prescribed conditions (i.e., time and temperature). Glasses were heat treated for these tests at $950^{\circ} \mathrm{C}$ and $1050^{\circ} \mathrm{C}$ for 70 hours. Glasses were also heat treated according to the DWPF CCC profile. Temperature readings were recorded electronically during heat treatment at time intervals of one minute. At the end of the heattreatment period, the glass samples were quenched by contacting the crucible with cold water. This quenching freezes in the phase assemblage in equilibrium with the melt at the heat-treatment temperature. The samples were then prepared for SEM/EDS examination by grinding and sieving $(-18 \mathrm{mesh},<1 \mathrm{~mm})$. The crystalline phases found in the heat-treated (or asmelted) glasses were characterized by SEM/EDS and the volume percents were obtained generally as the average of four viewing area counts from the powdered glass samples.

\subsubsection{Mossbauer Spectroscopy}

Mössbauer spectroscopy is an analytical technique that utilizes the recoil-free emission and resonant absorption of gamma rays by nuclei bound in solids. The energies of the gamma ray emitter (source) and absorber (sample) have to be closely matched and, therefore, the number of elements that can be studied using this technique is limited. One of the elements that has been studied extensively using Mössbauer spectroscopy is iron. In this work, Mössbauer spectroscopy was used to measure the fraction of iron in the $\mathrm{Fe}^{2+}$ and $\mathrm{Fe}^{3+}$ states, which can be used as a measure of the redox state of the glass sample.

Mössbauer spectra were collected using an American Magnetic/Ranger Scientific MS-1200 system equipped with a ${ }^{57} \mathrm{Co}$ source in a rhodium matrix with glass powder as the sample. Both divalent and trivalent iron show doublet peaks in the Mössbauer spectra, and the peak areas are proportional to the concentrations of the respective species in the glass. Even though the peaks overlap partially, software can be used to deconvolute the peaks and calculate the peak areas. The ratio of the areas of the $\mathrm{Fe}^{2+}$ and $\mathrm{Fe}^{3+}$ peaks is equal to the ratio of their concentrations in the glass. The redox measurements are calibrated using a set of six standard glass samples ranging in $\mathrm{Fe}^{2+}$ to $\mathrm{Fe}_{\text {total }}$ values from 7 to $90 \%$. The standards include a NIST traceable Obsidian Rock (SRM 278), five standard glasses analyzed by Corning, Inc. for their redox state, and the DWPF-EA glass. The NIST Standard iron foil (SRM 1541) was used to 
calibrate the instrument and determine the zero velocity channel. Since Doppler shifts in energy are measured in Mössbauer spectroscopy, the velocity is a measure of the shift in energy; knowing the zero velocity channel therefore helps in identifying the $\mathrm{Fe}^{2+}$ and $\mathrm{Fe}^{3+}$ peaks.

\subsubsection{Secondary Phases}

Secondary phases and inclusion of bubbles in the glass samples were determined by optical microscopy and/or SEM coupled with EDS. Secondary phases due to crystallization and phase separation can be identified using these methods. Secondary phases in the glasses studied in this work were mostly crystalline. Quantitative determination of the amount of crystals in glass samples were made by SEM in conjunction with image analysis.

\subsection{Melter Emission Samples}

Melter emission fluxes were measured to complete the mass balance for each DM100 test. Isokinetic melter exhaust samples (exhaust gas flow velocity equal to the velocity through the gas sample probe tip) was combined with the Fourier transform infra red (FTIR) spectroscopy continuous monitoring data for gaseous species to characterize fluxes from the melter. The off-gas sampling port used for isokinetic sampling is located prior to filtration in the transition line between the two temperature monitors, whereas the sample for FTIR analysis is pulled after high efficiency particulate air (HEPA) filtration prior to any dilution. Standard Environmental Protection Agency (EPA) isokinetic off-gas sampling trains and methods (EPA Methods 1A, 2, 4, 5, 26, 29), composed of particulate filters and liquid impingers, were used to collect materials that were subjected to chemical and physical analyses using the techniques described in Section 1.6. 


\section{SECTION 2.0 \\ WASTE COMPOSITION AND GLASS FORMULATION FOR SLUDGE BATCH 19}

\subsection{Waste Composition and Frit Development}

In order to assess the impacts of glass formulations with high $\mathrm{Al}_{2} \mathrm{O}_{3}$ concentrations on waste loading, melt rate, and waste throughput, this work utilized the highest $\mathrm{Al}_{2} \mathrm{O}_{3}$-containing sludge currently projected for DWPF processing. Table 2.1 lists the target waste composition specified by ORP/SRS, which is based on the projected composition of SB19 without high temperature Al-dissolution. This waste has the highest concentration of $\mathrm{Al}_{2} \mathrm{O}_{3}(34.308 \mathrm{wt} \%)$ among the DWPF sludge batches, with substantial quantities of $\mathrm{Na}_{2} \mathrm{O}(27.853 \mathrm{wt} \%)$ and $\mathrm{Fe}_{2} \mathrm{O}_{3}$ $(18.705 \mathrm{wt} \%)$ also present. The simulant composition resulted from the omission of the radioactive components (i.e., $\mathrm{ThO}_{2}$ and $\mathrm{U}_{3} \mathrm{O}_{8}$ ), which were not included in the current testing, followed by renormalization and conversion of $\mathrm{SO}_{4}$ to $\mathrm{SO}_{3}$. The conversion of $\mathrm{SO}_{4}$ to $\mathrm{SO}_{3}$ was performed because sulfur in glass is typically analyzed and reported as $\mathrm{SO}_{3}$. However, for evaluations using the DWPF Product Composition Control System (PCCS), sulfur was tracked as $\mathrm{SO}_{4}$. A total of four glass frits were formulated for the DWPF high- $\mathrm{Al}_{2} \mathrm{O}_{3} \mathrm{HLW}$ sludge. Table 2.2 summarizes the compositions of the formulated glass frits VS1 through VS4. All glass frits contain the components $\mathrm{B}_{2} \mathrm{O}_{3}, \mathrm{Li}_{2} \mathrm{O}$, and $\mathrm{SiO}_{2}$; a fourth component $(\mathrm{CaO})$ is present in VS2.

Tables 2.3 through 2.5 give the target compositions of the HLW glasses fabricated and tested at VSL using the HLW simulant and glass frits formulated at various waste loadings. Four HLW glasses were fabricated for each of VS1 (Table 2.3) and VS2 (Table 2.4). As seen in Tables 2.3 and 2.4, the waste loadings tested range from $45 \mathrm{wt} \%$ to $52 \mathrm{wt} \%$ (VS1) and $47 \mathrm{wt} \%$ to $54 \mathrm{wt} \%$ (VS2), significantly higher than the target minimum of $35 \mathrm{wt} \%$ to $40 \mathrm{wt} \%$. Table 2.5 lists the compositions of the HLW glasses fabricated and tested using VS3 (3 glasses, waste loading of $48 \mathrm{wt} \%$ to $52 \mathrm{wt} \%$ ) and VS4 (2 glasses, waste loadings of $48 \mathrm{wt} \%$ and $50 \mathrm{wt} \%$ ). Table 2.6 summarizes the combinations of glass frits and waste loadings tested.

The fabricated HLW glasses were analyzed for their compositions by XRF before property measurements were performed. Table 2.7 presents the XRF analyzed compositions of the HLW glasses. Glass samples were typically characterized first with respect to crystallinity after heat treatment because that is generally the most constraining property in attempts to increase waste loading. Isothermal heat treatment was performed at two different temperatures$950^{\circ} \mathrm{C}$ and $1050^{\circ} \mathrm{C}$ - for a time duration of 70 hours for most glasses. These two temperatures were chosen because (i) there is a large database at VSL of heat treatment data for HLW glasses at $950^{\circ} \mathrm{C}$ available for comparison and (ii) the DWPF processing conditions require that the liquids temperature $\left(\mathrm{T}_{\mathrm{L}}\right)$ of the $\mathrm{HLW}$ glass be $\leq 1050^{\circ} \mathrm{C}$ (not including measurement uncertainty). In addition to isothermal heat treatment, crucible glasses also underwent CCC heat treatment. The CCC temperature profile used for the DWPF canister cooling was provided by SRNL. Table 2.8 shows the CCC heat treatment schedule. Selected glass samples were also characterized with respect to viscosity, electrical conductivity, and 7-day PCT response (of both quenched and CCC glasses). 
Tables 2.9 through 2.11 present the characterization data for the HLW glasses formulated with VS1 (4 glasses), VS2 (4 glasses), and VS3 and VS4 (5 glasses total). For the VS1- and VS2-based glass formulations, it can be seen in Tables 2.9 and 2.10 that the progressive increases of waste loading reached $52 \mathrm{wt} \%$ and $54 \mathrm{wt} \%$, respectively, when spinel crystals were observed after heat treatment at $1050^{\circ} \mathrm{C}$. Crystallization of spinel increased considerably after $\mathrm{CCC}$ heat treatment for all HLW glasses so tested, while varying amounts (up to $6 \mathrm{vol} \%$ ) of nepheline also formed upon CCC heat treatment in the VS2-based glasses. The higher vol\% of crystals on CCC as compared to the isothermal heat treatments are probably due to the step changes in temperature along with hold points at different temperatures in the CCC profile; especially the hold points at $779^{\circ} \mathrm{C}, 715^{\circ} \mathrm{C}$ and $598^{\circ} \mathrm{C}$ (see Table 3). The PCT releases of the HLW glasses tested are invariably better than that of the benchmark DWPF-EA glass. The CCCversion of HWI-ALS-09, despite performing more poorly than the quenched glass because of nepheline formation, also outperformed the DWPF-EA glass.

The results for the VS3- and VS4- glass formulations are shown in Table 2.11. The viscosity of HWI-ALS-06 (based on VS4) was measured to be slightly outside of the DWPF processing requirement of $20 \mathrm{P} \leq$ melt viscosity $\leq 110 \mathrm{P}$ at $1150^{\circ} \mathrm{C}$ (not including measurement uncertainty). Also, all of these glasses showed spinel formation after $\mathrm{CCC}$ heat treatment, while nepheline was observed in VS3- formulations with waste loading $>50 \mathrm{wt} \%$.

It is interesting to note that these results show that the DWPF liquidus temperature limit can be met by glasses with up to $52 \mathrm{wt} \%$ waste loading and over $17 \mathrm{wt} \% \mathrm{Al}_{2} \mathrm{O}_{3}$.

The principal objective of the crucible-scale tests was to recommend the frit and glass formulation that should be employed for the subsequent DM100 melter tests. In view of the limited number of crucible melts allocated for this work, it is necessarily exploratory in nature; full optimization and associated composition envelope development would require a more extensive test matrix. However, the results obtained from this work demonstrate that compliant glasses can be formulated with high aluminum contents and waste loadings that are significantly higher than the levels targeted for this work [20]. In fact, there are several possible choices for compliant glasses with waste loadings in the $\sim 48 \mathrm{wt} \%$ range. Overall, however, the data led to the recommendation of Frit VS3 at $48 \mathrm{wt} \%$ loading, which yields the product glass composition HWI-ALS-05. The rationale for this selection can be summarized as follows:

- Glasses based on Frit VS4 showed low viscosity or high spinel content on CCC heat treatment

- Glasses based on Frit VS2 exhibited undesirable nepheline formation on CCC heat treatment (but did not fail PCT)

- Glasses based on Frit VS1 showed significantly higher spinel formation on CCC heat treatment than did the glass based on VS3 and comparable waste loading.

It is recognized that factors such as the presence of nepheline or high spinel content in the glass product (if the PCT is still passed) do not per se exclude such compositions from 
consideration. However, the test results indicate that comparable waste loading can be achieved with Frit VS3 while avoiding these issues, hence the recommendation of that frit for subsequent DM100 melter testing.

It is worth noting that the recommended glass system at $48 \mathrm{wt} \%$ waste loading does not pass the nepheline acceptability criterion of the DWPF PCCS and would be screened out as unacceptable by the present PCCS models. However, as can be seen from the measured data, nepheline formation is not observed in heat treated samples of this glass, although significant nepheline formation was observed at higher waste loadings. The PCCS predicts nepheline formation in this glass system at waste loadings above $41 \mathrm{wt} \%$. However, since the recommended glass composition is outside of the composition space covered by the DWPF PCCS database, its predictions with respect to the properties of the recommended glass can have large errors. Consequently, the data set on which the PCCS is built will have to be augmented and the PCCS revised in order to provide accurate predictions of glass properties in this composition space before this type of higher waste loading glass composition can be used for waste processing at the DWPF.

\subsection{Melter Feed Preparation}

As discussed in the Test Plan [20], most of the melter test support work for WTP was conducted using simulants prepared by mixing a set of chemicals to target the chemical composition of the projected waste in a process referred to as the direct-hydroxide method. In contrast to the WTP, at the DWPF the waste undergoes rather extensive chemical processing in the SRAT/SME cycle that is used to produce the melter feed. For the current melter tests, the simulated waste was prepared by the direct-hydroxide method and a co-precipitation/SRAT method such that a comparison could be made based on the processing rates and other data. The same target chemical composition was used for both simulants and did not include any radioactive components (see Table 2.1).

The formulation and procedure for preparing the co-precipitated simulant was specified and provided by SRS (Appendix I in [20]). The procedure sought to simulate the SRAT process at the DWPF. Table 2.12 summarizes the composition and the procedure to prepare the coprecipitated simulant. The preparation started with the precipitation of manganese dioxide and then iron and nickel hydroxides, followed by sludge washing and settling. The remaining components were then added and mixed, and the resulting sludge then undergoes the simulated SRAT process. The simulated SRAT process included addition of nitric acid $(50 \%)$ and formic acid $(90 \%)$ and dewatering. The amounts of nitric acid and formic acid added were calculated by SRR based on analytical results of the co-precipitated sludge, which are given in Table 2.13. The SRAT product was used in preparation of the melter feed at VSL by blending in the appropriate amount of glass frit. Instead of addition in a slurry of dilute formic solution followed by dewatering, however, the glass frit was added directly (i.e., the SME process was not simulated). The co-precipitated simulant was prepared by Harrell Industries and the glass additive was manufactured by Specialty Glass, Inc. The frit was received as glass cullet, crushed and sized at VSL targeting DWPF frit procurement specifications, most notably the 80 to 200 mesh grain size [32]. 
The chemical composition of the simulant prepared with the direct-hydroxide method is identical to that of the co-precipitated simulant not only in terms of the component oxides, but also in terms of the anions, including nitrate, nitrite, and formate. However, because of the different preparation methods, other anions such as hydroxide may be different in the two feeds. One purpose of the melter tests was to determine whether such differences would have any effect on the processing characteristics of the feed. Table 2.14 lists the analyzed compositions of selected anions for the SRAT product as received from Harrell Industries. In addition, to the extent possible, the same starting materials were used in the direct-hydroxide method as in the co-precipitated simulant (e.g., sodium aluminate and aluminum hydroxide were used, in the same proportion, to provide the target aluminum concentration). The primary differences are found in iron, manganese, and nickel, where iron hydroxide slurry, manganese oxide, and nickel oxide were, respectively, used instead of precipitation of the hydroxides during preparation. Note that, on a mass basis, both manganese and nickel are minor components. Another notable difference is the considerably lower amount of sodium nitrite, which resulted from the destruction of most of the nitrite in the SB19 sludge during the SRAT process. Table 2.15 lists the recipe for production of the direct-hydroxide simulant, which was prepared by NOAH Technologies, Inc. 


\section{SECTION 3.0 VERTICAL GRADIENT FURNANCE MELT RATE TESTING}

The waste throughput at DWPF, defined as the amount of sludge processed per unit time, is dependent on both waste loading and melt rate. While high waste loadings in HLW glasses reduce the canister count at DWPF, they have also been associated with decreased melt rates. A review of the DWPF operations has shown that as waste loading increases, the melt rate gradually decreases such that the maximum waste throughput at DWPF occurs at an intermediate waste loading for a particular glass frit/sludge waste combination [1]. Information about melt rates for a specific combination of glass frit/sludge waste as a function of waste loading is, therefore, important in determining the waste throughput at DWPF for the current melter configuration and processing parameters. While scale melter tests provide the most reliable melt rate information, small-scale screening tests of various types can also provide an efficient screening tool for glass formulation optimization. The vertical gradient furnace (VGF) is one such method that has proved effective in previous work [5].

The VGF provides melt rate data in a necessarily simplified fashion compared to that obtained from actual melter tests. However, as previous test results show [5], the VFG provides an economic and reliable method to determine the relative melt rates and to capture many of the essential features of the feed-to-glass conversion process. The cold cap in a continuously fed melter is subject to a large temperature gradient in the vertical direction. This temperature gradient can drive heat and mass flows and leads to variations of reaction rates at different heights in the cold cap, suggesting that the gradient can be a potentially significant factor in determining melt rate. In the VGF tests, dried feed is placed on top of pre-melted glass in a crucible and subjected to a vertical temperature gradient for predetermine times. The crucible is then quenched, sectioned, and examined to determine the nature and extent of the feed conversion process. The feed conversion from the VGF is rated on a relative scale (1 to 6) based on the visual evaluation of melter feed materials for a given temperature gradient and reaction time. The intent is not to compare the VGF sample directly to the melter cold cap. However, during conversion, the feed pile displays features that resemble the cold cap structure found inside a melter. Based on previous work with Hanford high aluminum HLW [5], an empirical correlation was developed between the (DM100) melter processing rate and the relative ranking by VGF, which is the primary basis for its utility in melt rate improvement work. Even though this correlation is based on data from a bubbled DM100, relative processing rate ranking by the VGF should be applicable to both bubbled and unbubbled melters. A description of the experimental method is provided in Section 1.4.

As part of the formulation development work, the DWPF high Al sludge simulant and the new glass frit (VS3) were blended at four different ratios and tested in a VGF for assessment of the relative melt rate. As shown in Figure 3.1 and Figure 3.2, the melter feed blends of $32 \mathrm{wt} \%$, $35 \mathrm{wt} \%$, and $38 \mathrm{wt} \%$ waste loadings reacted and fused rapidly in the VGF test environment. At the targeted $48 \mathrm{wt} \%$ waste loading, the conversion process of the high $\mathrm{Al}$ feed blend is still considered fast although some remnant of partially reacted feed blend materials are visible after a 
60 minute VGF run. Overall, the high Al feed blend converted rapidly in the VGF test environment and is ranked between 1 and 2 on a relative scale of 1 to 6 , with 1 the fastest and 6 the slowest [5].

Based on the results of the VGF screening tests, there are no obvious indications of sluggish melting or poor cold cap behavior and, based on the extent of conversion, the new high waste loading formulation would be predicted to exhibit a relatively high melt rate. As discussed below, this expectation was confirmed by the results of the DM100 melter runs. 


\section{SECTION 4.0 DM100 MELTER OPERATIONS}

Melter tests were conducted on the DM100-BL between 6/2/10 and 7/16/10. These tests produced almost one metric ton of glass from more than two metric tons of simulated waste (SB19) and over half a metric ton of glass frit. Prior to feeding the first test, the glass pool composition was adjusted by the of addition of select bulk chemicals in order to decrease the feeding time required to achieve the target composition in the glass pool. All tests were conducted at an $1150^{\circ} \mathrm{C}$ glass temperature and with plenum heaters on. The series of five fifty-hour tests was composed of the following:

- Co-precipitated waste simulant (Harrell Industries) - $612 \mathrm{~kg}$ of Glass Produced

o Test 1: air bubbling to achieve a glass production rate of $1125 \mathrm{~kg} / \mathrm{m}^{2} /$ day.

o Test 2: no bubbling.

o Test 3: argon bubbling to achieve a glass production rate of $1125 \mathrm{~kg} / \mathrm{m}^{2} /$ day.

- Direct-hydroxide simulant (NOAH Corporation) - $366 \mathrm{~kg}$ of Glass Produced

o Test 4: air bubbling to achieve a glass production rate of $1125 \mathrm{~kg} / \mathrm{m}^{2} /$ day.

o Test 5: no bubbling.

Summaries of the tests are provided in Tables 4.1 and 4.2. Overall, there were no significant difficulties in processing these feed and glass compositions during these tests once the solids content was reduced to 45 weight percent. The first nineteen hours of testing processed feed targeting 50 weight percent solids. A consistent feed rate could not be obtained with this feed due in part to intermittent clogging of feed lines. The feed was subsequently diluted with water to 45 weight percent solids, which greatly reduced the feed delivery issues. This feed solids content was used in all tests and only minor feeding interruptions due to feed line clogging occurred. Cold cap conditions were similar to the range of conditions observed in previous tests with HLW feeds [4, 5, 7-11, 23-26, 33]. The feed was relatively fluid spreading out relatively evenly across the melt pool surface; however, feed also adhered to melter walls to form "shelves" and "bridges" consistent with previous tests with other HLW simulants. Minor interruptions of 20 minutes or less occurred during testing in order to transfer feed to the feed tank, clear minor feed blockages from the feed tube, and, in one instance, to respond to a building fire alarm drill. A longer interruption of 187 minutes occurred during the last test due to Air Operated Diaphragm (AOD) pump failure and repair. Additional processing time was added to this test to compensate for the outage time. Spikes in feed rate often occurred immediately after feed transfers due to adjustments in tank mixer speeds and pump settings. During steadystate feeding periods, production rates typically vary by about ten percent from the mean rate. No foamy glass was observed in the glass discharge and no foam was observed on the melt pool surface or cold cap during any of the tests. This is in agreement with previous HLW melter tests for the WTP when foaming was rarely observed, even in cases where the measured iron redox ratios were zero or close to zero. 
Attempts were made to replicate the melter configuration and operating conditions used for previous tests with HLW simulants [4, 5, 7-11, 23-26, 33]. These conditions include a near-complete cold cap, which is between $80-95 \%$ melt surface coverage for the DM100 since a $100 \%$ cold cap tends to lead to "bridging" in smaller melters. However, bubblers were used in most previous tests, with either the bubbler flow held constant at $9 \mathrm{lpm}$ and the feed rate adjusted to achieve a cold cap limited production rate or the bubbler flow optimized to achieve the maximum production rate. In the current tests, either the bubbling was adjusted to achieve a feed rate equivalent to $1125 \mathrm{~kg} / \mathrm{m}^{2} /$ day glass production, or no bubbling was used and the melter was fed to cold-cap-limited conditions. The bubbler was not installed during Tests 2 and 5 ensuring that the bubbling was rigorously zero during these tests. The approach used in these tests was intended to determine the maximum production rate without bubbling and to determine the amount of bubbling required to produce glass at $1125 \mathrm{~kg} / \mathrm{m}^{2} /$ day. This permits the evaluation of the effects of waste simulation method and bubbling gas composition on production rate, product quality, and feed processing characteristics.

Figures 4.1.a - 4.1.d illustrate the glass production rates as moving hourly averages throughout the tests. Steady-state production rates for current and previous tests $[4,8,18,33]$ are tabulated in Table 4.3. As expected, the use of bubblers had a profound effect on production rate. Without bubblers, steady state production rates of about $400 \mathrm{~kg} / \mathrm{m}^{2} /$ day were achieved for feed containing waste simulated by two different processes, whereas with bubbling, the target production rate of $1125 \mathrm{~kg} / \mathrm{m}^{2} /$ day was easily attained using the same two feeds and using two different bubbling gas compositions. The rate achieved without bubbling in the current tests, matches the rate without bubbling achieved with SRS SB3 and is well within the range of $350-$ $650 \mathrm{~kg} / \mathrm{m}^{2} /$ day obtained with other HLW waste while not using bubblers. Given the relatively low level of bubbling required to achieve the target production rate, it is reasonable to expect that higher production rates could be achieved with SRS SB19 through bubbling rate optimization. In all but one of the feeds previously tested, production rates higher than the current target were achieved. The method of waste simulant preparation had no effect on the rate attained without bubbling, whereas a little less bubbling $(8.5 \mathrm{vs} .11 .8 \mathrm{lpm})$ was required to achieve the target rate for the waste simulated by the direct hydroxide method suggesting that that simulant may be slightly easier to process. The same bubbler gas flow was required to achieve the target production rate in tests with air and argon indicating that the use of argon as the bubbling gas does not affect the glass production rate.

The results of various operational measurements that were made during these tests are given in Table 4.4. Glass bubbling rates are shown in Figures 4.2.a - 4.2.c, glass temperatures are shown in Figures 4.3.a - 4.3.d, plenum temperatures in Figures 4.4.a - 4.4.d, electrode temperatures in Figures 4.5.a - 4.5.d, and glass resistance in Figures 4.6.a - 4.6.d; electrode power is included in the figures with electrode temperatures and glass resistance. The variability, and to a lesser degree, amount of bubbling required to achieve the target production rate of $1125 \mathrm{~kg} / \mathrm{m}^{2} /$ day was higher during Tests 1 and 3 than Test 5 , suggesting that the waste simulated by the direct hydroxide method forms a more uniform cold cap. Bulk glass temperatures (measured at 5 and 10 inches from the bottom of the melt pool) collectively averaged between 1149 and $1155^{\circ} \mathrm{C}$ and ranged largely within $10^{\circ} \mathrm{C}$ of the target glass temperature of $1150^{\circ} \mathrm{C}$ throughout the vast majority of the tests. Glass temperatures closer to the top of the melt pool (measured at 16 and 27 inches from the bottom) are not as reliable indicators of bulk glass 
temperatures as a result of their sensitivity to variations in the level of glass in the melter and gradients near the melt surface. Glass temperatures near the melt surface were lower and more variable during the tests without bubbling as a result of less efficient heat transfer to the melt surface. The airlift and discharge chamber temperatures were maintained above $950^{\circ} \mathrm{C}$ to facilitate glass discharge after the initial heating at the beginning of the test. Plenum temperatures were maintained above $600^{\circ} \mathrm{C}$ using plenum heaters. Test average plenum temperatures ranged from 632 to $688^{\circ} \mathrm{C}$ with temperatures measured in the thermowell being from 10 to $20^{\circ} \mathrm{C}$ lower than those from the exposed thermocouple. Higher plenum temperatures were measured at the beginning of each test until complete cold was formed and during feeding interruptions. The temperatures of the two electrode pairs were typically within 20 degrees of each other and were about 70 degrees lower than the glass pool during tests employing bubbling. The upper electrode temperatures are 50 to 100 degrees cooler without bubbling. The temperature trend for the bottom electrode was the reverse as a result of powering the bottom electrode during tests without bubbling - lower during tests with bubbling, at about $700^{\circ} \mathrm{C}$, and higher without bubbling, at about $900^{\circ} \mathrm{C}$. These electrode temperature trends with bubbling were also observed in previous tests processing SRS Sludge Batch 3 and 4 simulants [33]. Power supplied to the electrodes was typically around $11 \mathrm{~kW}$ without bubbling and around $23 \mathrm{~kW}$ with bubbling. As expected, more power was required as the bubbling rate and, therefore, production rate increased. The opposite trend is observed when power usage is normalized to glass production due to the amount of energy required to maintain the glass pool at the target melting temperature. The amount of power supplied to the plenum heaters was $2.5 \mathrm{~kW}$ throughout all the tests. The calculated glass pool resistance was relatively constant during steady state processing and higher during tests employing bubblers ( $0.06 \mathrm{vs.} 0.04 \mathrm{ohms}$ ), as would be expected.

The gas temperature at the film cooler averaged between $283-311^{\circ} \mathrm{C}$ and depended on the plenum temperature, the amount of added film cooler air, and the temperature of the added film cooler air. Drops of less than fifteen degrees in gas temperature were observed across the (insulated) transition line; the high temperature is maintained in order to prevent condensation in the downstream filtration units. 


\section{SECTION 5.0 \\ FEED SAMPLE AND GLASS PRODUCT ANALYSIS}

\subsection{Analysis of Frit Samples}

Frit samples from each composition were analyzed to confirm the chemical composition and the concentration of impurities in the frit. The methods used for analysis of feed sample chemical compositions are described in Section 1.7. The analyses of both frit types are compared to target compositions in Table 5.1. Data from both analytical methods indicate that the frit approximated the target composition; however, there are several oxides present as minor contaminants. Less than about a twentieth of a weight percent of oxides of barium, calcium, sulfur, and titanium, as well as chlorine, were measured by XRF. Similarly low concentrations of iron, potassium, magnesium, sodium, nickel, phosphorous, lead and zirconium were detected only by the DCP method. Slightly higher oxide concentrations of aluminum $(0.14$ and $0.18 \mathrm{wt} \%)$ were measured by both methods. These contaminants are not expected to have an effect on glass production rates or product glass durability; however, the target constituents are diluted slightly by their presence.

\subsection{Analysis of Feed Samples}

\subsubsection{General Properties and Composition}

Feed samples produced from each frit type were analyzed to determine physical properties and chemical composition. Samples were taken from an inline sampling port. Measured feed properties (density, water content, $\mathrm{pH}$, and glass yield) and compositions are given in Tables 5.2 - 5.4. The measured glass conversion ratios for feed samples were within nine percent of the target values, validating the use of the target conversion ratio for calculating glass production rates. Relatively little variation between the sample analyses for each property was observed, indicating consistent composition throughout the tests. Exceptions include the first feed sample, which was taken prior to the dilution of the feed from 50 to 45 weight percent solids. Also of note is the difference in $\mathrm{pH}$ from a value of about 9 in samples with waste simulated by the co-precipitation method and a $\mathrm{pH}$ of 4.5 for samples with waste simulated by the direct hydroxide addition method. Although the majority of the ingredients were the same in the two stimulant recipes (Tables 2.12 and 2.15), evidently, the co-precipitation process yields a significantly higher free hydroxide content in the final product than does the direct hydroxide method. The XRF method used for analysis of feed sample chemical compositions is described in Section 1.7. The boron and lithium oxide target values were used for normalizing the XRF data since their concentrations were not determined by XRF. These results generally corroborate the consistency of the feed with the two simulated SRS SB19 wastes, showing good agreement with the target compositions for the majority of the elements. The only element targeted at one percent oxide or greater that deviates more than ten percent from the target value is aluminum in the feed containing wastes produced by the co-precipitation method. The average aluminum concentration in the feed samples is $18.04 \mathrm{vs} 16.35 \mathrm{wt} \%$ oxide target. This 10.34 percent surplus 
in aluminum should not have a large effect on test results and any effect with respect to production rates is conservative given that aluminum incorporation into glass is slower than most other elements. Feed containing waste simulated by Harrell Industries had higher concentrations of $\mathrm{Cl}, \mathrm{Cr}, \mathrm{Cu}$, and $\mathrm{K}$ than the respective low target values; similar surpluses were observed for feed containing waste simulated by $\mathrm{NOAH}$ for $\mathrm{Mg}, \mathrm{Cr}$, and $\mathrm{S}$. These surpluses presumably reflect the low level contamination of different chemicals used to simulate the wastes. Positive deviations of this nature are often observed in melter feeds due to their ubiquity in the raw materials used to make up the simulants and in the glass forming additives.

\subsubsection{Rheology}

Melter feed samples containing waste simulated by both methods were analyzed to determine the effect of waste simulation method on rheological properties. Archived feed samples containing waste simulated by co-precipitation showed significant thickening over time. Therefore, a new sample was made up with the co-precipitated waste simulatnt and frit and then analyzed within 24 hours to determine the effect of feed aging on this feed. Rheograms showing feed viscosity versus shear rate are given in Figure 5.1; measured values for viscosity at selected shear rates and the yield stress values are shown in Table 5.5. The yield stress for feed containing waste simulated by the direct hydroxide method is 25 to 64 times less than that for the feed with waste simulated by the other method depending on the length of time the feed aged. The increase in feed viscosity with aging decreases as the shear rate increases to about $151 /$ secs when the viscosities become indistinguishable. The measured rheological properties for the samples corroborate the visual observations: feed containing waste simulated by the co-precipitation method is considerably more viscous than feed containing waste simulated by the direct hydroxide method and thickens over time. Measured rheological properties for the feed containing waste simulated by the direct hydroxide method are similar to many simulated Hanford HLW feeds processed in the DM1200 [10, 15, 16, 18] while the measured rheological properties for the feed containing waste simulated by co-precipitation are considerably more viscous than the simulated Hanford HLW feeds adjusted to the WTP upper rheological limit [18].

\subsection{Analysis of Glass Samples}

Almost a metric ton of glass was produced in these tests. The glass was discharged from the melter periodically into 5-gallon carbon steel pails using an airlift system. The discharged product glass was sampled at the end of each test by removing sufficient glass from the top of the cans for total inorganic analysis. Product glass masses, discharge date, and analysis performed are given in Table 5.6.

\subsubsection{Compositional Analysis of Discharge Glasses}

All discharge glass samples were crushed and analyzed directly by XRF. The target values for boron and lithium oxides, which are not determined by XRF, were used for 
normalizing the XRF data to $100 \mathrm{wt} \%$. The XRF analyzed compositions of discharged glass samples are provided in Table 5.7. The majority of the XRF analysis results compared very favorably to their corresponding target values and feed sample analyses (see Section 5.2.1). All oxides with a target concentration greater than 1 weight percent showed less than $10 \%$ deviation from the target values at the end of testing. At the end of processing the feed containing waste simulated by Harrell Industries, surpluses of calcium and aluminum were observed as a result of the higher than target concentrations in the glass pool at the start of the test and an above target concentration of aluminum in the feed. Minor constituents present in the melt pool at the start of testing at higher than target concentrations were nickel, lead, phosphorus, zinc and zirconium; all decrease to near target concentrations during testing. Bismuth was present in the melt pool at the beginning of testing at 0.7 weight percent oxide and decreased in concentration over the course of testing as a result of its absence in the feed. The low level contaminations of chlorine, chromium, cooper, potassium, magnesium and sulfur observed in feed samples were also observed in the product glass.

Corroborative analysis using DCP on solutions of acid-dissolved glass was performed on select glasses; the results are compared to the XRF analysis in Table 5.8. Values for all the major oxides compare favorably with the XRF analyses and target compositions except for sodium, which often exhibits a low bias using this procedure [34]. Lower values for aluminum and chromium were also measured by DCP, which in all but one analysis gives values closer to the target concentrations. The lower values probably represent a low bias for the DCP method as opposed to a high bias for the XRF method. The closeness of the DCP boron and lithium analyses to the target (deviations of less than 10\%) validates the use of the target boron and lithium concentrations for normalizing the XRF data.

Compositional trends for selected oxides shown in Figures 5.2.a- 5.2.h illustrate the closeness to targets at the end of tests with each composition and corroborate biases shown in the tabular data. Changes in the overall glass composition are not great in magnitude for the majority of elements as a result of adjustments made to the glass pool prior to testing. At the beginning of testing, alumina is above and silica below the respective target concentrations; this trend is reversed by the end of the test. Soda also starts out below the target concentration and increases to the target by the end of the first test. Iron and manganese track the target concentrations with a variability of about ten percent throughout the tests. Silicon, titanium, and cerium increase in concentration during testing at the expense of calcium, aluminum, bismuth, phosphorus, nickel, zinc (not shown), and boron (not shown), as the composition transitions from the starting glass pool composition at the beginning of the tests to the target composition over the course of the tests. The low level contamination of the two waste simulants with potassium, magnesium, or sulfur is also observed in comparison between the trends for Tests 1-3 and Test 4-5. Chromium is above the target throughout the tests due to a higher concentration in the glass pool at the onset of testing, low level contamination of the feed, and possible contributions from the corrosion of melter components. This higher than target chromium concentration in the glass due to corrosion of melter components is common during joule heated ceramic melter tests and no excessive corrosion of melter components was observed during the current tests. 


\subsubsection{Iron Oxidation State of Discharge Glasses}

Glass samples from the end of each test as well as all samples from Tests 3 and 5 were analyzed to determine the iron oxidation state. The results are given in Table 5.9 and depicted in Figures 5.3 and 5.4. DM100 melter samples from tests using SB19 Harrell simulant, without bubbling and with air bubbling, were fully oxidized. Glass samples from the Harrell simulant processed in the DM100 melter with argon bubbling showed redox state $\left(\mathrm{Fe}^{+2} / \mathrm{Fe}_{\text {tot }}\right)$ values as high as 0.18. Glass samples from the NOAH simulant processed in the DM100 melter without bubbling showed $\mathrm{Fe}^{+2} / \mathrm{Fe}_{\text {tot }}$ ratios of up to about 0.05 , whereas the samples from the test with air bubbling were fully oxidized. In both tests with samples containing measurable reduced iron, it is unclear if the iron oxidation state reached steady state over the course of the test; the concentration of divalent iron could potentially have further increased if the test duration had been longer.

In parallel with these tests, a number of closed crucible tests were conducted at the VSL using SB19 HLW feed simulant. Acid addition calculation for SB19 feed simulant was targeted to provide a redox ratio of 0.2 in terms of $\mathrm{Fe}^{+2} / \mathrm{Fe}_{\text {tot }}$. Prediction of the redox ratio per the SRNL calculation [35] yielded a value of 0.24. However, closed crucible tests with SB19 feed simulant produced glasses that were fully oxidized $\left(\mathrm{Fe}^{+2} / \mathrm{Fe}_{\text {tot }}\right.$ of 0.0 or 0.01$)$, in agreement with results obtained in melter tests with the same simulated waste using either no bubbling or air bubbling. These results are in contrast to the reported agreement in predicted and measured redox state for earlier sludge batches, which suggest a $\mathrm{Fe}^{+2} / \mathrm{Fe}_{\text {tot }}$ of 0.2 for melter feed containing SRS sludges [35-38]. Thus, the results from the SB19 glass samples, especially the closed crucible test samples, did not agree with the redox prediction. Contrary to the intention to partially reduce the glass melt, the SB19 simulant did not yield measurable amounts of divalent iron in the closed crucible tests. The SB19 feed simulant used in the current tests did not contain mercury or noble metals, both of which affect chemical reactions in the SRAT, whereas most of the feeds used in the DWPF redox prediction calculation [35] contained these components. Even though this difference can potentially be a source of error in the calculation of the amount of acid to be added to target a specific redox ratio, it should not affect the calculation of redox ratio based on the final feed analysis. The presence of free formic acid in the SB19 SRAT simulant as the reason for the difference is very unlikely given the high $\mathrm{pH}$ of the feed $(\sim 9)$. At this time, the reason for the inability of the model to predict the measured redox ratios for the SB19 SRAT simulant used in these tests is not known. Since multiple glass samples were analyzed and they all showed redox ratios of zero or close to zero for the samples from the closed crucible tests and melter tests without bubbling, it is safe to conclude that the true redox ratio of these samples is close to zero.

For the SB19 simulant, the closed crucible tests, melter tests with air bubbling, and melter tests without bubbling all gave almost fully oxidized glasses with the exception of the un-bubbled melter test with the NOAH simulant, which showed less than $5 \%$ of the iron as divalent. On the contrary, the melter test with argon bubbling yielded glass samples with up to $18 \%$ divalent iron. Furthermore, it appears that the divalent iron content of the melt had not reached steady-state by the end of the test and was still increasing. In the case of feed containing SB19 simulated by Harrell Industries, the closed crucible samples and samples from melter tests without bubbling and with air bubbling show similar redox ratios that are zero or close to zero. 
Therefore, it is reasonable to conclude that bubbling with argon makes the glass melt more reducing as compared to melt processing without bubbling, and with air bubbling.

\subsubsection{Chemical Durability of Discharge Glasses}

Glass discharge samples from the end of Tests 1 and 3 were evaluated for chemical durability using the PCT method. These glasses were selected to assess any effects of bubbling with air and argon on glass durability for glass produced from waste simulated by the co-precipitation method. The samples were collected from the discharge cans and were not subjected to CCC heat treatment prior to the test. The PCT results are compared to those for the benchmark DWPF-EA glass in Table 5.10. By this measure, the chemical durability of the melter glasses is excellent. All measured PCT concentrations and normalized leach rates on discharge glass samples are at least an order of magnitude lower than the corresponding values for the DWPF-EA glass. The normalized concentrations for both glasses are very similar, indicating that bubbling with either air or argon at the rates used in these melter tests does not have any affect on product durability. The results also agree well with the PCT results for crucible glass samples presented in Table 2.11.

\subsubsection{Secondary Phase and Porosity Determination of Discharge Glasses}

Glass discharge samples from the end of Tests 1 and 3 were analyzed for secondary phases by microscopy using methods described in Section 1.7.6. These glasses were selected to show the relative effect of bubbling with air and argon on the tendency to form secondary phases and to create voids in glass produced from waste simulated by the co-precipitation method. Secondary phases constituted only 0.8 to 0.9 volume percent of the two glasses. The crystals were iron and chromium rich spinels with lesser amounts of nickel and aluminum. The as-melted crucible glass sample did not show any crystals, whereas the crucible glass sample subjected to CCC showed about $0.6 \mathrm{vol} \%$ of spinel crystals (see Table 2.11). One difference between the crucible and melter glass samples is that the crucible glass samples are fully oxidized, the melter glass sample with air bubbling has no measurable amount of $\mathrm{Fe}^{2+}$, and the melter glass sample with argon bubbling has about $18 \%$ of the iron in the $\mathrm{Fe}^{2+}$ state. The cooling of the glass in the melter discharge cans will be slower than the cooling of the as-melted glass, but faster than the CCC profile. Both the redox state of the glass and the thermal history will affect the amount of crystals in the glass sample. No porosity was detected in either glass sample except for one 23 micron vesicle. This observation corroborates macroscopic observations during the test that the glass did not contain air pockets or foam when discharged from tests using the bubbler. There were no discernable differences between the glasses from tests using air or argon as the bubbling gas. 


\section{SECTION 6.0 \\ MONITORED OFF-GAS EMISSIONS}

\subsection{Particulate Sampling}

The melter exhaust was sampled for metals/particles according to 40-CFR-60 Methods 3, 5, and 29 at steady-state operating conditions during each test. The concentrations of off-gas species that are present as particulates and gaseous species that are collected in impinger solutions were derived from laboratory data on solutions extracted from air samples (filters and various solutions) together with measurements of the volume of air sampled. Particulate collection required isokinetic sampling, which entails removing gas from the exhaust at the same velocity that the air is flowing in the duct (40-CFR-60, Methods 1-5). Typically, a sample size of 30 dscf was taken at a rate of between 0.5 and $0.75 \mathrm{dscfm}$. Total particulate loading was determined by combining gravimetric analysis of the standard particle filter and chemical analysis of probe rinse solutions. An additional impinger containing $2 \mathrm{~N} \mathrm{NaOH}$ was added to the sampling train to ensure complete scrubbing of all acid gases and, particularly, iodine. The collected materials were analyzed using direct current plasma atomic emission spectroscopy for the majority of the constituents and ion chromatography (IC) for anions. Melter emission fluxes are compared to feed fluxes in Tables 6.1 and 6.2. Notice the distinction that is made between constituents sampled as particles and as "gas". The "gaseous" constituents are operationally defined as those species that are scrubbed in the impinger solutions after the air stream has passed through a $0.3 \mu \mathrm{m}$ heated filter. All samples are well within the $90-110 \%$ limits for isokinetic sampling.

Particulate emissions from the melter constituted 0.04 to 1.36 percent of feed solids, depending on the method used to fabricate the waste simulant and, secondarily, the use of bubblers used to agitate the melt pool. Interestingly, the measured carryover was seventeen to eighteen times higher in tests processing waste simulated by the direct hydroxide method than comparable tests processing waste simulated using the co-precipitation method. This difference suggests that characteristics of co-precipitated simulated waste, perhaps the high viscosity, high yield stress, and $\mathrm{pH}$ create cold cap conditions that inhibit particulate carryover. To the extent that the co-precipitation process more closely models the actual DWPF waste the results also suggests that carryover from the actual waste at DWPF will be low. The increase in solids carryover with bubbling in the current tests is compared to tests conducted on the melters at VSL (DM100 and DM1200) with and without bubbling, as shown in Table 6.3. Overall, the increase in solids carryover was from 1.77 to 8.19 times greater in tests with bubbling, depending greatly on the intensity of bubbling used (as well as the bubbler configuration). In one pair of tests, the carryover without bubbling was actually about half that for the bubbled test based on triplicate measurements for both conditions. In test pairs evaluating carryover increase while processing SRS SB19 targeting a production rate of $1125 \mathrm{~kg} / \mathrm{m}^{2} /$ day (400 canisters a year) the carryover increase with bubbling is about a factor of two. This condition is closest to being representative of expectations for bubbler deployment at the DWPF; many of the other tests target considerably greater increases in glass production rate and showed correspondingly larger increases in 
carryover. Tests maximizing the glass throughput with higher relative bubbling rates show the greatest increase in solids carryover, as was observed in the tests with SRS Sludge Batch 4, another high aluminum waste composition [33]. No significant difference in particulate carryover was measured while bubbling with argon in place of air.

The feed contains very low or no concentrations of volatile species, such as halides, and therefore many elemental volatility trends commonly observed in melter exhaust data are not as obvious in the data from these tests. As expected, the feed element emitted at the lowest melter decontamination factor (DF) was clearly sulfur, with six to eighty percent of the feed sulfur reporting to melter emissions. Chlorine, fluorine, phosphorus and, to a lesser degree, sulfur are in such low concentrations in the feed and are commonly present in chemicals as impurities that accurate carryover of these elements is difficult to determine. Similarly, calcium and magnesium are over represented in the melter exhaust due to their ubiquity as trace contaminants in feed additives and laboratory chemicals. In data from Tests 1 and 3, emissions appear to be influenced more by elemental volatility: sulfur has the highest carryover, followed by $\mathrm{Pb}, \mathrm{B}, \mathrm{K}$, and $\mathrm{Cr}$, followed by $\mathrm{Na}$, followed by non-volatile elements such as $\mathrm{Si}, \mathrm{Al}, \mathrm{Fe}$, and $\mathrm{Zr}$. Although some elements follow this trend in Tests 4 and 5, the relatively high concentration of most elements in the melter exhaust suggests physical entrainment of feed constituents in the exhaust. Boron, sulfur, and chlorine were the only elements detected in the impinger solutions collected downstream of the heated particle filter in the sampling train, which constitutes the "gas" fraction of the melter emissions.

\subsection{Gases Monitored by FTIR}

Melter emissions were monitored in each test for a variety of gaseous components, most notably $\mathrm{CO}$ and nitrogen species, by Fourier Transform Infra-Red Spectroscopy (FTIR). Monitoring for hydrogen was performed using Gas Chromatography (GC). The GC was equipped with a $3^{\prime} \mathrm{X} 1 / 8^{\prime \prime}$ stainless-steel column packed with molecular sieve 5A and a thermal conductivity detector operated with an argon carrier gas at 4 psi and a column temperature of $40^{\circ} \mathrm{C}$. The unit was calibrated against certified standard gases of nominally 10,100 , and 1000 ppmv hydrogen in air. The limit of detection of this system was below the 10-ppmv lower calibration point but was not further quantified. The off-gas system temperature is maintained well above $100^{\circ} \mathrm{C}$ beyond the sampling port downstream of the HEPA filter to prevent analyte loss due to condensation prior to monitoring. A summary of average concentrations monitored during each test is provided in Table 6.4. Also included are the calculated concentrations of the monitored gasses in the melter plenum taking into account dilution in the off-gas system including the film cooler.

The analytes listed in Table 6.4 are those that were thought likely to be observed during the test based on previous work; no other species were detected in the off-gas stream by FTIR. The most abundant nitrogen species monitored was NO, which is in keeping with previous melter tests with both Hanford HLW and LAW feeds. The relative concentrations of nitrogen oxides, carbon oxides, and water decrease with decreasing production rate in Tests 2 and 5 , as expected. Measured carbon concentrations in tests processing feed containing waste simulated by the direct hydroxide method were higher than in comparable tests with feed containing waste 
simulated by co-precipitation method, suggesting that the feed produced by NOAH contains higher concentrations of carbon. Conversely, higher concentrations of hydrogen were measured during tests with feed containing waste simulated by the co-precipitation method, indicating that carbon concentration alone is not the only factor contributing to hydrogen emissions. No clear emissions trend was observed with the use of argon as a bubbling gas in place of air. Hydrogen fluoride was observed only during tests with feed containing waste simulated by the co-precipitation method, suggesting that this feed contains more fluorine, perhaps due to trace level contamination of the feed. No hydrogen cyanide, nitric acid, nitrous acid, sulfur dioxide, or hydrogen chloride, were detected in emissions by the FTIR. 


\section{SECTION 7.0 SUMMARY AND CONCLUSIONS}

A series of tests was conducted on the DM100-BL vitrification system installed at VSL to evaluate enhanced HLW glass formulations for the SRS SB19 waste. The melter tests evaluated the effects of glass pool bubbling, using argon as a bubbling gas in place of air, and the procedure used to simulate the waste. A new glass formulation was developed with the objectives of achieving a high waste loading for this high aluminum waste stream; a waste loading on oxide basis of 48 percent was obtained. The formulation used for melter testing was selected based on the test results from a series of crucible melt glasses that were prepared and characterized and vertical gradient furnace melt rate tests. The selected formulation meets all of the measured product quality, processability, and waste loading requirements. The product quality as measured by the PCT protocol was verified on glasses produced during melter testing.

Properties of the crucible and melter glasses were measured to demonstrate that they meet the DWPF processing and product quality requirements. However, assessment of the glass compositions with the DWPF PCCS showed a number of glass compositions at higher waste loadings as failing the acceptance criteria for nepheline formation and viscosity, even though measurements of these properties for the higher waste loading glasses showed that they do meet the acceptance criteria. This is likely due to the fact that the compositions of these glasses are outside of the composition range of glasses used to develop the PCCS. Historically, higher waste loading glass formulations for high-Al HLW were not used at the DWPF in part because of their low processing rates. Recent deployment of a bubbler system into the DWPF melter has alleviated concerns about low processing rate of HLW feeds. However, even with bubblers, revision of the PCCS will be necessary to use any high waste loading (more than about $41 \mathrm{wt} \%$ ) glass formulation at the DWPF for treating high-Al HLW because the current PCCS will incorrectly flag good glass compositions as not meeting the acceptance criterion, especially with respect to nepheline formation.

Melter testing on the DM100 was performed in five, nominally fifty-hour test segments. These test segments employed a glass pool temperature of $1150^{\circ} \mathrm{C}$, plenum heaters, and feed containing waste simulated by two different methods (co-precipitation and direct hydroxide). Tests were conducted without bubbling and with bubbling sufficient to produce glass at a rate of $1125 \mathrm{~kg} / \mathrm{m}^{2} /$ day (400 canisters per year) and using air or argon as the bubbler gas. Almost a metric ton of glass was produced from more than two metric tons of simulated waste (SRS SB19) and over half a metric ton of glass frit. Analysis was performed on discharge and glass pool samples collected throughout the tests for total composition and secondary phases. All of the melter tests were successfully completed with no evidence of processing issues at a feed solids content of 45 weight percent. The target glass production rate of $1125 \mathrm{~kg} / \mathrm{m}^{2} /$ day was achieved with modest amount of glass pool bubbling using waste simulants produced by both methods, as well as with air and argon as the bubbling gas. The same amount of bubbling was used while bubbling with either air or argon indicating the different gas types used do not affect the rate of production. Approximately a third less bubbling was used while processing the feed 
containing waste simulated by the direct hydroxide addition method, suggesting that it is somewhat easier to process. A production rates of $400 \mathrm{~kg} / \mathrm{m}^{2} /$ day was achieved without bubbling for feed containing waste simulated by both methods.

Based on the test results we would recommend the direct hydroxide simulant if the objective is to determine the processing rate of the feed because the observed difference in processing rate with the two feeds is not significant. If the objective is to determine melter emissions, we would recommend the SRAT simulant because the observed difference in emissions is significant contrary to previous tests for WTP [9] that showed little difference in the melter emissions for direct hydroxide and precipitated simulants. For either simulant, the omission of $\mathrm{Hg}$ and noble metals could affect the reliability of redox predictions because of their potential effect on formic acid reactions in the SRAT.

During each test, melter exhaust was sampled for particulate and gaseous species to determine the effect of the variations in feed chemistry, bubbling rate, and glass temperature on emissions. Total particulate carryover from the melter into the off-gas stream was 0.04 to 1.36 percent. Interestingly, the most significant factor affecting solids carryover was the process used to simulate the waste: carryover was seventeen to eighteen times higher in tests processing feed containing waste simulated using the direct hydroxide method as compared to the coprecipitation method. The differences between the feeds include higher $\mathrm{pH}$, higher viscosity, and higher yield stress for the co-precipitated feed. Due to the different preparation methods, the particle size of the feed and speciation of the chemical components also will be different. Evidently, these property changes result in a cold cap that better limits carryover. The use of bubbling to obtain the DWPF target glass production rate equivalent to 400 canisters per year increased particulate carryover by a factor of a little more than two. Melter DFs were determined for most elements in the feed for each test. The most volatile species was sulfur. Gaseous emissions of nitrogen oxides and byproducts of incomplete combustion, such as carbon monoxide, were mostly proportional to feed processing rate. Carbon emissions were higher for comparable tests with the feed containing the waste generated by the direct hydroxide method, whereas hydrogen emissions were higher in comparable tests with the feed containing the waste generated by the co-precipitation method. No discernable difference in emissions was noted as a result of using argon as a bubbling gas in place of air.

The only evident consequence of using argon in place of air as a bubbling gas was the reduction of iron in the product glass to $18 \%$ percent divalent iron in contrast to no measurable divalent iron in tests with air as the bubbling gas. Although argon is often considered "inert", it necessarily introduces a local low-oxygen environment. When a glass melt is equilibrated with a gas phase (e.g., by gas sparging), it will absorb or take up oxygen as dictated by the underlying redox equilibria. If the gas phase is rich in oxygen, the melt will tend to take up oxygen from the gas and multivalent redox species will tend to move towards their higher oxidation states. Conversely, if the gas phase is poor in oxygen, the melt will tend to give up oxygen to the gas phase and multivalent redox species will tend to move towards their lower oxidation states (i.e., they will be reduced, as is summarized in Le Chatelier's Principle). The equilibrium positions of the redox couples in the glass melt are thus fixed by the oxygen fugacity in the equilibrium gas phase. Consequently, in terms of the position of these redox couples in general, and that of the $\mathrm{Fe}^{2+} / \mathrm{Fe}^{3+}$ couple in particular, equilibrating the melt with air will necessarily tend to create a 
lower $\mathrm{Fe}^{2+} / \mathrm{Fe}_{\text {tot }}$ ratio, and equilibration of the melt with argon will tend to create a higher $\mathrm{Fe}^{2+} / \mathrm{Fe}_{\text {tot }}$ ratio. However, in terms of degree of this effect, it is important to note that the redox ratio depends logarithmically on the oxygen fugacity. Consequently, the reducing power of an "oxygen-free" "inert" gas such as argon depends crucially on the trace concentration of oxygen in that gas. These effects have been investigated systematically in borosilicate glasses and extensively documented [39]. Based on Schreiber's data [40], a residual concentration of oxygen of $\sim 5$ ppm would give an equilibrium $\mathrm{Fe}^{2+} / \mathrm{Fe}_{\text {tot }}$ ratio of about $20 \%$, whereas $\sim 0.1$ ppm would give an equilibrium $\mathrm{Fe}^{2+} / \mathrm{Fe}_{\text {tot }}$ ratio of nearly $40 \%$. It should be noted, however, that these equilibrium conditions will be approached but may or may not be achieved in practice due to the dynamic nature of the actual glass melting process.

DWPF plans to install bubblers in the melter and use argon as the bubbling gas to improve feed processing rate. Since the DM100 melter tests indicate that bubbling with argon is likely to yield a more reducing glass as compared to no bubbling, the DWPF feed preparation strategy should consider this effect. At this time, there are not sufficient data available to predict the exact magnitude of the increase in the redox state of the glass melt with argon bubbling. In the current tests with $\mathrm{SB} 19$, even though a $\mathrm{Fe}^{2+} / \mathrm{Fe}_{\text {tot }}$ ratio of 0.2 was targeted, analysis of multiple glass samples from closed crucible tests and melter tests without bubbling showed redox ratios of zero or close to zero. Bubbling with argon shifted the redox state to about 0.18. Given that argon bubbling shifted the redox state of an essentially fully oxidized glass $\left(\mathrm{Fe}^{2+} / \mathrm{Fe}_{\text {tot }}\right.$ $\sim 0.0$ ) to a redox state of about 0.18 , it is likely that if the feed without argon bubbling had yielded the targeted redox state of 0.2 , bubbling with argon would have made the glass yet more reducing. If, for example, these effects were additive, the redox state would be above the DWPF upper redox limit and into the range where formation of deleterious metal and sulfide phases becomes an issue.

In view of the observed differences between targeted and measured redox ratios, limited understanding of the magnitude of the effect of argon bubbling on redox state, and deleterious impacts of over reducing conditions on melter life, it is recommended that during feed preparation, the redox state be targeted towards the oxidizing end of the current operating range to allow for additional reducing impact from argon bubbling.

For future operations at DWPF with argon bubbling, it would be useful to better understand the effect of argon bubbling on glass redox state. This can be accomplished through a combination of crucible-scale tests to determine the magnitude and kinetics of the change in redox state with argon bubbling, a limited number of melter tests to confirm the results from crucible-scale tests in the presence of a cold cap and under the dynamic conditions prevailing in an actual melter of reasonable scale, and analysis of additional samples from the DWPF melter to better understand the actual redox history. 


\section{SECTION 8.0 REFERENCES}

[1] "Initial MAR Assessments to Assess the Impact of Al-dissolution on DWPF Operating Windows," J.D. Newell, T.B. Edwards, and D.K. Peeler, WSRC-STI-2007-00688, Rev. 0, Savannah River National Laboratory, Aiken, SC, December 2007.

[2] "Downstream Impacts of Sludge Mass Reduction via Aluminum Dissolution on DWPF Processing of Savannah River Site High Level Waste," J.M. Pareizs, C.J. Bannochie, M.S. Hay, and D.J. McCabe, WM2009 Waste Management for the Nuclear Renaissance, Phoenix, AZ, March 2009.

[3] "International Study of Aluminum Impacts on Crystallization in U.S. High Level Waste Glass," K.M. Fox, D.K. Peeler, T.B. Edwards, D.R. Best, I.A. Reamer, R.J. Workman, J.C. Marra, B.J. Riley, J.D. Vienna, J.V. Crum, J. Matyas, A.B. Edmondson, J.B. Lang, N.M. Ibarra, A. Fluegel, A. Aloy, A.V. Trofimenko, and R. Soshnikov, SRNS-STI-200800057, Rev. 0, Savannah River National Laboratory, Aiken, SC, September 2008.

[4] "High Level Waste Vitrification System Improvements," K.S. Matlack, H. Gan, W. Gong, I.L. Pegg, C.C. Chapman, and I. Joseph, VSL-07R1010-1, Rev. 0, Vitreous State Laboratory, The Catholic University of America, Washington, DC, 04/16/07.

[5] "Melt Rate Enhancement for High Aluminum HLW Glass Formulations," K.S. Matlack, H. Gan, M. Chaudhuri, W. Kot, W. Gong, T. Bardakci, I.L. Pegg, and I. Joseph, VSL08R1360-1, Rev. 0, Vitreous State Laboratory, The Catholic University of America, Washington, DC, 12/19/08.

[6] "Glass Formulation to Support Melter Runs with HLW Simulants," Final Report, W.K. Kot, K. Klatt, and I.L. Pegg, VSL-03R3760-2, Rev. 0, Vitreous State Laboratory, The Catholic University of America, Washington, DC, 8/8/03.

[7] "HLW Glass Formulation to Support C-106/AY-102 Actual Waste Testing," W.K. Kot and I.L. Pegg, VSL-04R4770-1, Rev. 0, Vitreous State Laboratory, The Catholic University of America, Washington, DC, 8/12/04.

[8] "Melter Tests with AZ-101 HLW Simulant Using a DuraMelter 100 Vitrification System," K.S. Matlack, W.K. Kot, and I.L. Pegg, VSL-01R10N0-1, Rev. 1, Vitreous State Laboratory, The Catholic University of America, Washington, DC, 2/25/01.

[9] "DuraMelter 100 HLW Simulant Validation Tests with C-106/AY-102 Feeds," K.S. Matlack, W. Gong, and I.L. Pegg, VSL-05R5710-1, Rev. 0, Vitreous State Laboratory, The Catholic University of America, Washington, DC, 6/2/05. 
[10] "Integrated DM1200 Melter Testing of HLW C-106/AY-102 Composition Using Bubblers," K.S. Matlack, W. Gong, T. Bardakci, N. D’Angelo, W. Kot, and I.L. Pegg, VSL-03R3800-1, Rev. 0, Vitreous State Laboratory, The Catholic University of America, Washington, DC, 9/15/03.

[11] "Integrated DM1200 Melter Testing of HLW C-104/AY-101 Compositions Using Bubblers," K.S. Matlack, W. Gong, T. Bardakci, N. D’Angelo, W. Kot, and I.L. Pegg, VSL-03R3800-3, Rev. 0, Vitreous State Laboratory, The Catholic University of America, Washington, DC, 11/24/03.

[12] "DM1200 Tests with AZ-101 HLW Simulants," K.S. Matlack, W. Gong, T. Bardakci, N. D'Angelo, W.K. Kot, and I.L. Pegg, VSL-03R3800-4, Rev. 0, Vitreous State Laboratory, The Catholic University of America, Washington, DC, 2/17/04.

[13] "Start-Up and Commissioning Tests on the DM1200 HLW Pilot Melter System Using AZ-101 Waste Simulants," K.S. Matlack, M. Brandys, and I.L. Pegg, VSL-01R0100-2, Rev. 1, Vitreous State Laboratory, The Catholic University of America, Washington, DC, 10/31/01.

[14] "Tests on the DuraMelter 1200 HLW Pilot Melter System Using AZ-101 HLW Simulants," K.S. Matlack, W.K. Kot, T. Bardakci, T.R. Schatz, W. Gong, and I.L. Pegg, VSL-02R0100-2, Rev. 0, Vitreous State Laboratory, The Catholic University of America, Washington, DC, 6/11/02.

[15] "Integrated DM1200 Melter Testing of HLW AZ-102 Compositions Using Bubblers," K.S. Matlack, W. Gong, T. Bardakci, N. D’Angelo, W. Kot, and I.L. Pegg, VSL03R3800-2, Rev. 0, Vitreous State Laboratory, The Catholic University of America, Washington, DC, 9/24/03.

[16] "Integrated DM1200 Melter Testing of Redox Effects Using HLW AZ-101 and C-106/AY-102 Simulants," K.S. Matlack, W. Gong, T. Bardakci, N. D’Angelo, W. Lutze, P. M. Bizot, R. A. Callow, M. Brandys, W.K. Kot, and I.L. Pegg, VSL04R4800-1, Rev. 0, Vitreous State Laboratory, The Catholic University of America, Washington, DC, 5/6/04.

[17] "Integrated DM1200 Melter Testing of Bubbler Configurations Using HLW AZ-101 Simulants," K.S. Matlack, W. Gong, T. Bardakci, N. D’Angelo, W. Lutze, R. A. Callow, M. Brandys, W.K. Kot, and I.L. Pegg, VSL-04R4800-4, Rev. 0, Vitreous State Laboratory, The Catholic University of America, Washington, DC, 10/5/04.

[18] "Integrated DM1200 Melter Testing Using AZ-102 and C-106/AY-102 HLW Simulants: HLW Simulant Verification," K.S. Matlack, W. Gong, T. Bardakci, N. D’Angelo, M. Brandys, W.K. Kot, and I.L. Pegg, VSL-05R5800-1, Rev. 0, Vitreous State Laboratory, The Catholic University of America, Washington, DC, 6/27/05. 
[19] ORP Contract No. DE-AC27-07RV14884, A003, "Savannah River Site (SRS) Workscope" Department of Energy, Office of River Protection, Richland, WA, 2/4/09.

[20] "Glass Formulation Development and Testing for DWPF High- $\mathrm{Al}_{2} \mathrm{O}_{3}$ HLW Sludges," K.S. Matlack, W.K. Kot, and I.L. Pegg, VSL-09T1670-1, Rev. 0, Vitreous State Laboratory, The Catholic University of America, Washington, DC, 06/04/09.

[21] "Testing to Assess the Impact of Argon vs. Air as a Bubbler Gas for the DWPF," K.S. Matlack, W.K. Kot, and I.L. Pegg, VSL-10T2030-1, Rev. 0, Vitreous State Laboratory, The Catholic University of America, Washington, DC, 03/15/10

[22] ORP Contract No. DE-AC27-07RV14884, A008, "Additional Test with SRS HLW SRAT/SME Simulant," Department of Energy, Office of River Protection, Richland, WA, 12/27/09.

[23] "Technetium/Cesium Volatility in DM100 Tests Using HLW AZ-102 and LAW SubEnvelope A1 Simulants," K.S. Matlack, W.K. Kot, and I.L. Pegg, VSL-04R4710-1, Rev. 0, Vitreous State Laboratory, The Catholic University of America, Washington, DC, 9/28/04.

[24] "Small Scale Melter Testing of HLW Algorithm Glasses: Matrix 1 Tests," K.S. Matlack, W.K. Kot, W. Gong, and I.L. Pegg, VSL-07R1220-1, Rev. 0, Vitreous State Laboratory, The Catholic University of America, Washington, DC, 11/12/07.

[25] “Small Scale Melter Testing of HLW Algorithm Glasses: Matrix 2 Tests," K.S. Matlack, W.K. Kot, W. Gong, and I.L. Pegg, VSL-08R1220-1, Rev. 0, Vitreous State Laboratory, The Catholic University of America, Washington, DC, 6/27/08.

[26] "Effects of High Spinel and Chromium Oxide Crystal Contents on Simulated HLW Vitrification in DM100 Melter Tests," K.S. Matlack, W.K. Kot, W. Gong, W. Lutze,, I Joseph, and I.L. Pegg, VSL-09R1520-1, Rev. 0, Vitreous State Laboratory, The Catholic University of America, Washington, DC, 6/19/09.

[27] "Quality Assurance Project Plan for ORP RPP-WTP Support Activities Conducted by VSL," Vitreous State Laboratory, VSL-QAPP-ORP, Rev. 2, Vitreous State Laboratory, The Catholic University of America, Washington, DC, 2/2/10.

[28] "Master List of Controlled VSL Manuals and Standard Operating Procedures in Use," QA-MLCP, Rev. 54, Vitreous State Laboratory, The Catholic University of America, Washington, DC, 9/20/10.

[29] "Physical and Rheological Properties of Waste Simulants and Melter Feeds for RPPWTP HLW Vitrification," W.K. Kot, H. Gan, and I.L. Pegg, VSL-00R2520-1, Rev. 0, Vitreous State Laboratory, The Catholic University of America, Washington, DC, 10/31/01. 
[30] "Round Robin Testing of a Reference Glass for Low-Activity Waste Forms," W.L. Ebert and S.F. Wolf, Department of Energy report ANL-99/22, Argonne National Laboratory, Argonne, IL, 1999.

[31] Jantzen, C. M., Bibler, N. E., Beam, D. C., Crawford, C. L., and Pickett, M. A., "Characterization of the Defense Waste Processing Facility (DWPF) Environmental Assessment (EA) Glass Standard Reference Material," WSRC-TR-92-346, Westinghouse Savannah River Company, Aiken, SC, June, 1993.

[32] "Specification for Procurement of DWPF Frit," Rev. 8, Specification No. X-SPP-S00018 , June 2008.

[33] "SRS Vitrification System Improvements," K.S. Matlack, W. Kot, W. Gong and I.L. Pegg, VSL-07R1270-1, Rev. 0, Vitreous State Laboratory, The Catholic University of America, Washington, DC, 6/30/07.

[34] "Review of Properties of Simulated Feeds Used for Melter Testing," K.S. Matlack, W. Gong, and I.L. Pegg, Final Report, VSL-06R6410-1, Rev. 0, Vitreous State Laboratory, The Catholic University of America, Washington, DC, Washington, D.C., 8/16/06.

[35] "Defense Waste Processing Facility (DWPF) Sludge Batch 6 (SB6) Redox Evaluation," J.D. Newell, SRNL-L3100-2010-00073, Savannah River National Laboratory, Aiken, SC, June, 2010.

[36] "Role of Manganese Reduction/Oxidation (Redox) on Foaming and Melt Rate in High Level Waste (HLW) Melters (U)", C.M Jantzen, and M.E. Stone, WSRC-STI-200600066, Rev 0, Savannah River National Laboratory, Aiken, SC, March 2007.

[37] "Sludge Batch 4 Baseline Melt Rate Furnace and Slurry-Fed Melt Rate Furnace Tests with Frits 418 and 510," M.E. Smith, T.M. Jones, and D.H. Miller, WSRC-STI-200700450, Savannah River National Laboratory, Aiken, SC, September, 2007.

[38] "Characterization of Defense Waste Processing Facility (DWPF) Glass and Deposit Samples from Melter \#2 (U)", C.M. Jantzen, A.D. Cozzi, and N.E. Bibler, WSRC-TR2003-00502, Rev. 0, Savannah River Technology Center, Aiken, SC, 3/1/04.

[39] "Improving Technetium Retention in Hanford LAW Glass - Phase 1," K.S. Matlack, I.S. Muller, I. Joseph, and I.L. Pegg, Final Report, VSL-10R1920-1, Rev. 0, Vitreous State Laboratory, The Catholic University of America, Washington, DC, 3/19/10.

[40] "An Electrochemical Series of Redox Couples in Silicate Melts: A Review and Application s of Geochemistry,” H. D. Schreiber, J. Geophys. Res., 92, 9225 (1987). 
Table 2.1. Projected Compositions (wt\%) of the SRS High Aluminum-Based Sludge and the HLW Simulant.

\begin{tabular}{|c|c|c|}
\hline Waste Oxide & $\begin{array}{l}\text { DWPF High-Al } \\
\text { Sludge }\end{array}$ & HLW Simulant \\
\hline $\mathrm{Al}_{2} \mathrm{O}_{3}$ & $34.308 \%$ & $34.505 \%$ \\
\hline $\mathrm{BaO}$ & $0.183 \%$ & $0.184 \%$ \\
\hline $\mathrm{CaO}$ & $2.837 \%$ & $2.853 \%$ \\
\hline $\mathrm{Ce}_{2} \mathrm{O}_{3}$ & $0.196 \%$ & $0.197 \%$ \\
\hline $\mathrm{Cr}_{2} \mathrm{O}_{3}$ & $0.323 \%$ & $0.325 \%$ \\
\hline $\mathrm{CuO}$ & $0.085 \%$ & $0.085 \%$ \\
\hline $\mathrm{Fe}_{2} \mathrm{O}_{3}$ & $18.705 \%$ & $18.812 \%$ \\
\hline $\mathrm{K}_{2} \mathrm{O}$ & $0.213 \%$ & $0.214 \%$ \\
\hline $\mathrm{La}_{2} \mathrm{O}_{3}$ & $0.105 \%$ & $0.106 \%$ \\
\hline $\mathrm{MgO}$ & $0.375 \%$ & $0.377 \%$ \\
\hline $\mathrm{MnO}$ & $1.786 \%$ & $1.796 \%$ \\
\hline $\mathrm{Na}_{2} \mathrm{O}$ & $27.853 \%$ & $28.013 \%$ \\
\hline $\mathrm{NiO}$ & $0.319 \%$ & $0.321 \%$ \\
\hline $\mathrm{PbO}$ & $0.070 \%$ & $0.070 \%$ \\
\hline $\mathrm{SO}_{4}$ & $0.168 \%$ & $0.141 \%^{*}$ \\
\hline $\mathrm{SiO}_{2}$ & $8.271 \%$ & $8.318 \%$ \\
\hline $\mathrm{ThO}_{2}$ & $0.001 \%$ & - \\
\hline $\mathrm{TiO}_{2}$ & $3.096 \%$ & $3.114 \%$ \\
\hline $\mathrm{U}_{3} \mathrm{O}_{8}$ & $0.542 \%$ & - \\
\hline $\mathrm{ZnO}$ & $0.092 \%$ & $0.093 \%$ \\
\hline $\mathrm{ZrO}_{2}$ & $0.473 \%$ & $0.476 \%$ \\
\hline TOTAL & $100.00 \%{ }^{(\mathrm{a})}$ & $100.00 \%$ \\
\hline
\end{tabular}


The Catholic University of America Vitreous State Laboratory
Glass Formulation Development and Testing for DWPFHigh- $\mathrm{Al}_{2} \mathrm{O}_{3} \mathrm{HLW}$ Sludges Final Report, VSL-10R1670-1, Rev. 0

Table 2.2. Compositions (wt\%) of the Glass Frits Formulated for the HLW Simulant.

\begin{tabular}{|c||c|c|c|c|}
\hline Oxide & VS1 & VS2 & VS3 & VS4 \\
\hline \hline $\mathrm{B}_{2} \mathrm{O}_{3}$ & $32.00 \%$ & $28.00 \%$ & $20.00 \%$ & $31.00 \%$ \\
\hline $\mathrm{CaO}$ & - & $5.00 \%$ & - & - \\
\hline $\mathrm{Li}_{2} \mathrm{O}$ & $7.00 \%$ & $6.00 \%$ & $10.00 \%$ & $9.00 \%$ \\
\hline $\mathrm{SiO}_{2}$ & $61.00 \%$ & $61.00 \%$ & $70.00 \%$ & $60.00 \%$ \\
\hline
\end{tabular}

— Empty data field 
Table 2.3. Composition (wt \%) of the HLW Glasses Prepared with Glass Frit VS1.

\begin{tabular}{|c|c|c|c|c|}
\hline Glass ID & HWI-ALS-01 & HWI-ALS-03 & HWI-ALS-07 & HWI-ALS-08 \\
\hline Waste Loading & $45 \mathrm{wt} \%$ & $48 \mathrm{wt} \%$ & $50 \mathrm{wt} \%$ & $52 \mathrm{wt} \%$ \\
\hline $\mathrm{Al}_{2} \mathrm{O}_{3}$ & $15.53 \%$ & $16.56 \%$ & $17.25 \%$ & $17.94 \%$ \\
\hline $\mathrm{B}_{2} \mathrm{O}_{3}$ & $17.60 \%$ & $16.64 \%$ & $16.00 \%$ & $15.36 \%$ \\
\hline $\mathrm{BaO}$ & $0.08 \%$ & $0.09 \%$ & $0.09 \%$ & $0.10 \%$ \\
\hline $\mathrm{CaO}$ & $1.28 \%$ & $1.37 \%$ & $1.43 \%$ & $1.48 \%$ \\
\hline $\mathrm{Ce}_{2} \mathrm{O}_{3}$ & $0.09 \%$ & $0.09 \%$ & $0.10 \%$ & $0.10 \%$ \\
\hline $\mathrm{Cr}_{2} \mathrm{O}_{3}$ & $0.15 \%$ & $0.16 \%$ & $0.16 \%$ & $0.17 \%$ \\
\hline $\mathrm{CuO}$ & $0.04 \%$ & $0.04 \%$ & $0.04 \%$ & $0.04 \%$ \\
\hline $\mathrm{Fe}_{2} \mathrm{O}_{3}$ & $8.47 \%$ & $9.03 \%$ & $9.41 \%$ & $9.78 \%$ \\
\hline $\mathrm{K}_{2} \mathrm{O}$ & $0.10 \%$ & $0.10 \%$ & $0.11 \%$ & $0.11 \%$ \\
\hline $\mathrm{La}_{2} \mathrm{O}_{3}$ & $0.05 \%$ & $0.05 \%$ & $0.05 \%$ & $0.05 \%$ \\
\hline $\mathrm{Li}_{2} \mathrm{O}$ & $3.85 \%$ & $3.64 \%$ & $3.50 \%$ & $3.36 \%$ \\
\hline $\mathrm{MgO}$ & $0.17 \%$ & $0.18 \%$ & $0.19 \%$ & $0.20 \%$ \\
\hline $\mathrm{MnO}$ & $0.81 \%$ & $0.86 \%$ & $0.90 \%$ & $0.93 \%$ \\
\hline $\mathrm{Na}_{2} \mathrm{O}$ & $12.61 \%$ & $13.45 \%$ & $14.01 \%$ & $14.57 \%$ \\
\hline $\mathrm{NiO}$ & $0.14 \%$ & $0.15 \%$ & $0.16 \%$ & $0.17 \%$ \\
\hline $\mathrm{PbO}$ & $0.03 \%$ & $0.03 \%$ & $0.04 \%$ & $0.04 \%$ \\
\hline $\mathrm{SO}_{3}$ & $0.06 \%$ & $0.07 \%$ & $0.07 \%$ & $0.07 \%$ \\
\hline $\mathrm{SiO}_{2}$ & $37.29 \%$ & $35.71 \%$ & $34.66 \%$ & $33.61 \%$ \\
\hline $\mathrm{TiO}_{2}$ & $1.40 \%$ & $1.49 \%$ & $1.56 \%$ & $1.62 \%$ \\
\hline $\mathrm{ZnO}$ & $0.04 \%$ & $0.04 \%$ & $0.05 \%$ & $0.05 \%$ \\
\hline $\mathrm{ZrO}_{2}$ & $0.21 \%$ & $0.23 \%$ & $0.24 \%$ & $0.25 \%$ \\
\hline TOTAL & $100.0 \%$ & $100.0 \%$ & $100.0 \%$ & $100.0 \%$ \\
\hline
\end{tabular}


Table 2.4. Composition (wt \%) of the HLW Glasses Prepared with Glass Frit VS2.

\begin{tabular}{|c|c|c|c|c|}
\hline Glass ID & HWI-ALS-02 & HWI-ALS-04 & HWI-ALS-09 & HWI-ALS-10 \\
\hline Waste Loading & $47 \mathrm{wt} \%$ & $50 \mathrm{wt} \%$ & $52 \mathrm{wt} \%$ & $54 \mathrm{wt} \%$ \\
\hline $\mathrm{Al}_{2} \mathrm{O}_{3}$ & $16.22 \%$ & $17.25 \%$ & $17.94 \%$ & $18.63 \%$ \\
\hline $\mathrm{B}_{2} \mathrm{O}_{3}$ & $14.84 \%$ & $14.00 \%$ & $13.44 \%$ & $12.88 \%$ \\
\hline $\mathrm{BaO}$ & $0.09 \%$ & $0.09 \%$ & $0.10 \%$ & $0.10 \%$ \\
\hline $\mathrm{CaO}$ & $3.99 \%$ & $3.93 \%$ & $3.88 \%$ & $3.84 \%$ \\
\hline $\mathrm{Ce}_{2} \mathrm{O}_{3}$ & $0.09 \%$ & $0.10 \%$ & $0.10 \%$ & $0.11 \%$ \\
\hline $\mathrm{Cr}_{2} \mathrm{O}_{3}$ & $0.15 \%$ & $0.16 \%$ & $0.17 \%$ & $0.18 \%$ \\
\hline $\mathrm{CuO}$ & $0.04 \%$ & $0.04 \%$ & $0.04 \%$ & $0.05 \%$ \\
\hline $\mathrm{Fe}_{2} \mathrm{O}_{3}$ & $8.84 \%$ & $9.41 \%$ & $9.78 \%$ & $10.16 \%$ \\
\hline $\mathrm{K}_{2} \mathrm{O}$ & $0.10 \%$ & $0.11 \%$ & $0.11 \%$ & $0.12 \%$ \\
\hline $\mathrm{La}_{2} \mathrm{O}_{3}$ & $0.05 \%$ & $0.05 \%$ & $0.05 \%$ & $0.06 \%$ \\
\hline $\mathrm{Li}_{2} \mathrm{O}$ & $3.18 \%$ & $3.00 \%$ & $2.88 \%$ & $2.76 \%$ \\
\hline $\mathrm{MgO}$ & $0.18 \%$ & $0.19 \%$ & $0.20 \%$ & $0.20 \%$ \\
\hline $\mathrm{MnO}$ & $0.84 \%$ & $0.90 \%$ & $0.93 \%$ & $0.97 \%$ \\
\hline $\mathrm{Na}_{2} \mathrm{O}$ & $13.17 \%$ & $14.01 \%$ & $14.57 \%$ & $15.13 \%$ \\
\hline $\mathrm{NiO}$ & $0.15 \%$ & $0.16 \%$ & $0.17 \%$ & $0.17 \%$ \\
\hline $\mathrm{PbO}$ & $0.03 \%$ & $0.04 \%$ & $0.04 \%$ & $0.04 \%$ \\
\hline $\mathrm{SO}_{3}$ & $0.07 \%$ & $0.07 \%$ & $0.07 \%$ & $0.08 \%$ \\
\hline $\mathrm{SiO}_{2}$ & $36.24 \%$ & $34.66 \%$ & $33.61 \%$ & $32.55 \%$ \\
\hline $\mathrm{TiO}_{2}$ & $1.46 \%$ & $1.56 \%$ & $1.62 \%$ & $1.68 \%$ \\
\hline $\mathrm{ZnO}$ & $0.04 \%$ & $0.05 \%$ & $0.05 \%$ & $0.05 \%$ \\
\hline $\mathrm{ZrO}_{2}$ & $0.22 \%$ & $0.24 \%$ & $0.25 \%$ & $0.26 \%$ \\
\hline TOTAL & $100.0 \%$ & $100.0 \%$ & $100.0 \%$ & $100.0 \%$ \\
\hline
\end{tabular}


Table 2.5. Composition (wt\%) of the HLW Glasses Prepared with Glass Frits VS3 and VS4.

\begin{tabular}{|c|c|c|c|c|c|}
\hline Glass ID & HWI-ALS-05 & HWI-ALS-06 & HWI-ALS-11 & HWI-ALS-12 & HWI-ALS-13 \\
\hline $\begin{array}{c}\text { Waste } \\
\text { Loading }\end{array}$ & $48 \mathrm{wt} \%$ (VS3) & $48 w t \%(V S 4)$ & $50 \mathrm{wt} \%$ (VS4) & $50 \mathrm{wt} \%$ (VS3) & $52 \mathrm{wt} \%(\mathrm{VS} 3)$ \\
\hline $\mathrm{Al}_{2} \mathrm{O}_{3}$ & $16.56 \%$ & $16.56 \%$ & $17.25 \%$ & $17.25 \%$ & $17.94 \%$ \\
\hline $\mathrm{B}_{2} \mathrm{O}_{3}$ & $10.40 \%$ & $16.12 \%$ & $15.50 \%$ & $10.00 \%$ & $9.60 \%$ \\
\hline $\mathrm{BaO}$ & $0.09 \%$ & $0.09 \%$ & $0.09 \%$ & $0.09 \%$ & $0.10 \%$ \\
\hline $\mathrm{CaO}$ & $1.37 \%$ & $1.37 \%$ & $1.43 \%$ & $1.43 \%$ & $1.48 \%$ \\
\hline $\mathrm{Ce}_{2} \mathrm{O}_{3}$ & $0.09 \%$ & $0.09 \%$ & $0.10 \%$ & $0.10 \%$ & $0.10 \%$ \\
\hline $\mathrm{Cr}_{2} \mathrm{O}_{3}$ & $0.16 \%$ & $0.16 \%$ & $0.16 \%$ & $0.16 \%$ & $0.17 \%$ \\
\hline $\mathrm{CuO}$ & $0.04 \%$ & $0.04 \%$ & $0.04 \%$ & $0.04 \%$ & $0.04 \%$ \\
\hline $\mathrm{Fe}_{2} \mathrm{O}_{3}$ & $9.03 \%$ & $9.03 \%$ & $9.41 \%$ & $9.41 \%$ & $9.78 \%$ \\
\hline $\mathrm{K}_{2} \mathrm{O}$ & $0.10 \%$ & $0.10 \%$ & $0.11 \%$ & $0.11 \%$ & $0.11 \%$ \\
\hline $\mathrm{La}_{2} \mathrm{O}_{3}$ & $0.05 \%$ & $0.05 \%$ & $0.05 \%$ & $0.05 \%$ & $0.05 \%$ \\
\hline $\mathrm{Li}_{2} \mathrm{O}$ & $5.20 \%$ & $4.68 \%$ & $4.50 \%$ & $5.00 \%$ & $4.80 \%$ \\
\hline $\mathrm{MgO}$ & $0.18 \%$ & $0.18 \%$ & $0.19 \%$ & $0.19 \%$ & $0.20 \%$ \\
\hline $\mathrm{MnO}$ & $0.86 \%$ & $0.86 \%$ & $0.90 \%$ & $0.90 \%$ & $0.93 \%$ \\
\hline $\mathrm{Na}_{2} \mathrm{O}$ & $13.45 \%$ & $13.45 \%$ & $14.01 \%$ & $14.01 \%$ & $14.57 \%$ \\
\hline $\mathrm{NiO}$ & $0.15 \%$ & $0.15 \%$ & $0.16 \%$ & $0.16 \%$ & $0.17 \%$ \\
\hline $\mathrm{PbO}$ & $0.03 \%$ & $0.03 \%$ & $0.04 \%$ & $0.04 \%$ & $0.04 \%$ \\
\hline $\mathrm{SO}_{3}$ & $0.07 \%$ & $0.07 \%$ & $0.07 \%$ & $0.07 \%$ & $0.07 \%$ \\
\hline $\mathrm{SiO}_{2}$ & $40.39 \%$ & $35.19 \%$ & $34.16 \%$ & $39.16 \%$ & $37.93 \%$ \\
\hline $\mathrm{TiO}_{2}$ & $1.49 \%$ & $1.49 \%$ & $1.56 \%$ & $1.56 \%$ & $1.62 \%$ \\
\hline $\mathrm{ZnO}$ & $0.04 \%$ & $0.04 \%$ & $0.05 \%$ & $0.05 \%$ & $0.05 \%$ \\
\hline $\mathrm{ZrO}_{2}$ & $0.23 \%$ & $0.23 \%$ & $0.24 \%$ & $0.24 \%$ & $0.25 \%$ \\
\hline TOTAL & $100.0 \%$ & $100.0 \%$ & $100.0 \%$ & $100.0 \%$ & $100.0 \%$ \\
\hline
\end{tabular}


Table 2.6. Combinations of Glass Frits and Waste Loadings Tested.

\begin{tabular}{|c|c|c|c|c|}
\hline $\begin{array}{r}\text { Glass Frit } \\
\text { Waste Loading }\end{array}$ & VS1 & VS2 & VS3 & VS4 \\
\hline $\mathbf{4 5} \mathbf{w t} \%$ & HWI-ALS-01 & & & \\
\hline $\mathbf{4 6} \mathbf{w t} \%$ & & & & \\
\hline $\mathbf{4 7} \mathbf{w t} \%$ & & HWI-ALS-02 & & HWI-ALS-06 \\
\hline $\mathbf{4 8} \mathbf{w t} \%$ & HWI-ALS-03 & & & \\
\hline $\mathbf{4 9} \mathbf{w t} \%$ & & & HWI-ALS-05 & HWI-ALS-11 \\
\hline $\mathbf{5 0} \mathbf{w t} \%$ & HWI-ALS-07 & HWI-ALS-04 & & \\
\hline $\mathbf{5 1} \mathbf{w t} \%$ & & & HWI-ALS-13 & \\
\hline $\mathbf{5 2} \mathbf{w t} \%$ & HWI-ALS-08 & HWI-ALS-09 & & \\
\hline $\mathbf{5 3} \mathbf{w t} \%$ & & & & \\
\hline $\mathbf{5 4} \mathbf{w t} \%$ & & HWI-ALS-10 & & \\
\hline
\end{tabular}


Table 2.7. Compositional Analysis of HLW Glass by XRF (wt\%).

\begin{tabular}{|c|c|c|c|c|}
\hline & HWI-ALS-01 & HWI-ALS-02 & HWI-ALS-03 & HWI-ALS-04 \\
\hline $\mathrm{Al}_{2} \mathrm{O}_{3}$ & $15.27 \%$ & $15.59 \%$ & $16.06 \%$ & $16.47 \%$ \\
\hline $\mathrm{As}_{2} \mathrm{O}_{5}$ & - & - & - & - \\
\hline $\mathrm{B}_{2} \mathrm{O}_{3}{ }^{*}$ & $17.60 \%$ & $14.84 \%$ & $16.64 \%$ & $14.00 \%$ \\
\hline $\mathrm{BaO}$ & $0.12 \%$ & $0.10 \%$ & $0.11 \%$ & $0.11 \%$ \\
\hline $\mathrm{CaO}$ & $1.31 \%$ & $4.34 \%$ & $1.49 \%$ & $4.26 \%$ \\
\hline $\mathrm{Ce}_{2} \mathrm{O}_{3}$ & $0.12 \%$ & $0.11 \%$ & $0.12 \%$ & $0.14 \%$ \\
\hline $\mathrm{Cl}$ & - & - & $0.01 \%$ & $0.01 \%$ \\
\hline $\mathrm{CoO}$ & $0.01 \%$ & $0.01 \%$ & $0.01 \%$ & $0.01 \%$ \\
\hline $\mathrm{Cr}_{2} \mathrm{O}_{3}$ & $0.19 \%$ & $0.21 \%$ & $0.21 \%$ & $0.22 \%$ \\
\hline $\mathrm{CuO}$ & $0.05 \%$ & $0.06 \%$ & $0.06 \%$ & $0.07 \%$ \\
\hline $\mathrm{Er}_{2} \mathrm{O}_{3}$ & $0.02 \%$ & $0.01 \%$ & $0.02 \%$ & $0.01 \%$ \\
\hline $\mathrm{Fe}_{2} \mathrm{O}_{3}$ & $8.88 \%$ & $9.84 \%$ & $9.58 \%$ & $10.48 \%$ \\
\hline $\mathrm{Ga}_{2} \mathrm{O}_{3}$ & - & $0.00 \%$ & - & - \\
\hline $\mathrm{HfO}_{2}$ & - & - & - & $0.01 \%$ \\
\hline $\mathrm{Ho}_{2} \mathrm{O}_{3}$ & - & - & - & - \\
\hline $\mathrm{K}_{2} \mathrm{O}$ & $0.12 \%$ & $0.14 \%$ & $0.13 \%$ & $0.14 \%$ \\
\hline $\mathrm{Li}_{2} \mathrm{O}^{*}$ & $3.85 \%$ & $3.18 \%$ & $3.64 \%$ & $3.00 \%$ \\
\hline $\mathrm{MgO}$ & $0.15 \%$ & $0.15 \%$ & $0.18 \%$ & $0.16 \%$ \\
\hline $\mathrm{MnO}$ & $0.92 \%$ & $0.97 \%$ & $0.96 \%$ & $1.04 \%$ \\
\hline $\mathrm{Na}_{2} \mathrm{O}$ & $12.90 \%$ & $12.89 \%$ & $13.57 \%$ & $13.83 \%$ \\
\hline $\mathrm{NiO}$ & $0.15 \%$ & $0.17 \%$ & $0.17 \%$ & $0.18 \%$ \\
\hline $\mathrm{P}_{2} \mathrm{O}_{5}$ & $0.03 \%$ & $0.03 \%$ & $0.02 \%$ & $0.02 \%$ \\
\hline $\mathrm{PbO}$ & $0.04 \%$ & $0.04 \%$ & $0.03 \%$ & $0.04 \%$ \\
\hline $\mathrm{SO}_{3}$ & $0.09 \%$ & $0.08 \%$ & $0.09 \%$ & $0.09 \%$ \\
\hline $\mathrm{SiO}_{2}$ & $36.53 \%$ & $35.34 \%$ & $35.03 \%$ & $33.67 \%$ \\
\hline $\mathrm{Sm}_{2} \mathrm{O}_{5}$ & - & - & - & - \\
\hline $\mathrm{SnO}_{2}$ & $0.00 \%$ & $0.01 \%$ & $0.00 \%$ & - \\
\hline $\mathrm{SrO}$ & $0.01 \%$ & $0.01 \%$ & $0.01 \%$ & $0.01 \%$ \\
\hline $\mathrm{Tb}_{4} \mathrm{O}_{7}$ & $0.01 \%$ & & $0.01 \%$ & - \\
\hline $\mathrm{TiO}_{2}$ & $1.36 \%$ & $1.58 \%$ & $1.58 \%$ & $1.70 \%$ \\
\hline $\mathrm{V}_{2} \mathrm{O}_{5}$ & - & - & - & - \\
\hline $\mathrm{Y}_{2} \mathrm{O}_{3}$ & - & - & $0.00 \%$ & - \\
\hline $\mathrm{ZnO}$ & $0.05 \%$ & $0.05 \%$ & $0.05 \%$ & $0.06 \%$ \\
\hline $\mathrm{ZrO}_{2}$ & $0.22 \%$ & $0.24 \%$ & $0.24 \%$ & $0.26 \%$ \\
\hline TOTAL & $100.0 \%$ & $100.0 \%$ & $100.0 \%$ & $100.0 \%$ \\
\hline
\end{tabular}

${ }^{*} \mathrm{~B}_{2} \mathrm{O}_{3}$ and $\mathrm{Li}_{2} \mathrm{O}$ are not measured by XRF; target values are used.

- Empty data field. 
Table 2.7. Compositional Analysis of HLW Glass by XRF (wt\%) (continued).

\begin{tabular}{|c|c|c|c|c|}
\hline & HWI-ALS-05 & HWI-ALS-06 & HWI-ALS-07 & HWI-ALS-08 \\
\hline $\mathrm{Al}_{2} \mathrm{O}_{3}$ & $16.15 \%$ & $15.95 \%$ & $16.75 \%$ & $17.08 \%$ \\
\hline $\mathrm{As}_{2} \mathrm{O}_{5}$ & - & - & - & $0.00 \%$ \\
\hline $\mathrm{B}_{2} \mathrm{O}_{3}{ }^{*}$ & $10.40 \%$ & $16.12 \%$ & $16.00 \%$ & $15.36 \%$ \\
\hline $\mathrm{BaO}$ & $0.11 \%$ & $0.13 \%$ & $0.13 \%$ & $0.09 \%$ \\
\hline $\mathrm{CaO}$ & $1.48 \%$ & $1.50 \%$ & $1.57 \%$ & $1.62 \%$ \\
\hline $\mathrm{Ce}_{2} \mathrm{O}_{3}$ & $0.12 \%$ & $0.12 \%$ & $0.14 \%$ & $0.13 \%$ \\
\hline $\mathrm{Cl}$ & $0.01 \%$ & $0.01 \%$ & $0.01 \%$ & $0.01 \%$ \\
\hline $\mathrm{CoO}$ & $0.01 \%$ & $0.01 \%$ & $0.01 \%$ & $0.01 \%$ \\
\hline $\mathrm{Cr}_{2} \mathrm{O}_{3}$ & $0.21 \%$ & $0.22 \%$ & $0.22 \%$ & $0.24 \%$ \\
\hline $\mathrm{CuO}$ & $0.06 \%$ & $0.06 \%$ & $0.06 \%$ & $0.07 \%$ \\
\hline $\mathrm{Er}_{2} \mathrm{O}_{3}$ & $0.01 \%$ & $0.02 \%$ & $0.02 \%$ & $0.01 \%$ \\
\hline $\mathrm{Fe}_{2} \mathrm{O}_{3}$ & $9.80 \%$ & $10.20 \%$ & $10.52 \%$ & $11.03 \%$ \\
\hline $\mathrm{Ga}_{2} \mathrm{O}_{3}$ & - & $0.00 \%$ & - & $0.00 \%$ \\
\hline $\mathrm{HfO}_{2}$ & $0.01 \%$ & $0.01 \%$ & - & $0.01 \%$ \\
\hline $\mathrm{Ho}_{2} \mathrm{O}_{3}$ & - & - & - & - \\
\hline $\mathrm{K}_{2} \mathrm{O}$ & $0.16 \%$ & $0.15 \%$ & $0.15 \%$ & $0.15 \%$ \\
\hline $\mathrm{Li}_{2} \mathrm{O}^{*}$ & $5.20 \%$ & $4.68 \%$ & $3.50 \%$ & $3.36 \%$ \\
\hline $\mathrm{MgO}$ & $0.17 \%$ & $0.18 \%$ & $0.14 \%$ & $0.18 \%$ \\
\hline $\mathrm{MnO}$ & $0.99 \%$ & $1.02 \%$ & $1.06 \%$ & $1.11 \%$ \\
\hline $\mathrm{Na}_{2} \mathrm{O}$ & $13.29 \%$ & $13.13 \%$ & $13.59 \%$ & $14.96 \%$ \\
\hline $\mathrm{NiO}$ & $0.17 \%$ & $0.17 \%$ & $0.18 \%$ & $0.19 \%$ \\
\hline $\mathrm{P}_{2} \mathrm{O}_{5}$ & $0.03 \%$ & $0.03 \%$ & $0.03 \%$ & $0.01 \%$ \\
\hline $\mathrm{PbO}$ & $0.04 \%$ & $0.04 \%$ & $0.04 \%$ & $0.04 \%$ \\
\hline $\mathrm{SO}_{3}$ & $0.08 \%$ & $0.09 \%$ & $0.08 \%$ & $0.09 \%$ \\
\hline $\mathrm{SiO}_{2}$ & $39.58 \%$ & $34.20 \%$ & $33.75 \%$ & $32.10 \%$ \\
\hline $\mathrm{Sm}_{2} \mathrm{O}_{5}$ & $0.10 \%$ & - & - & - \\
\hline $\mathrm{SnO}_{2}$ & $0.00 \%$ & $0.00 \%$ & $0.00 \%$ & - \\
\hline $\mathrm{SrO}$ & $0.01 \%$ & $0.01 \%$ & $0.01 \%$ & $0.01 \%$ \\
\hline $\mathrm{Tb}_{4} \mathrm{O}_{7}$ & $0.01 \%$ & $0.01 \%$ & $0.01 \%$ & - \\
\hline $\mathrm{TiO}_{2}$ & $1.60 \%$ & $1.64 \%$ & $1.70 \%$ & $1.78 \%$ \\
\hline $\mathrm{V}_{2} \mathrm{O}_{5}$ & - & - & $0.00 \%$ & $0.00 \%$ \\
\hline $\mathrm{Y}_{2} \mathrm{O}_{3}$ & $0.00 \%$ & - & $0.00 \%$ & $0.00 \%$ \\
\hline $\mathrm{ZnO}$ & $0.05 \%$ & $0.06 \%$ & $0.06 \%$ & $0.06 \%$ \\
\hline $\mathrm{ZrO}_{2}$ & $0.25 \%$ & $0.26 \%$ & $0.27 \%$ & $0.26 \%$ \\
\hline TOTAL & $100.1 \%$ & $100.0 \%$ & $100.0 \%$ & $100.0 \%$ \\
\hline
\end{tabular}

${ }^{*} \mathrm{~B}_{2} \mathrm{O}_{3}$ and $\mathrm{Li}_{2} \mathrm{O}$ are not measured by XRF; target values are used.

- Empty data field. 
Table 2.7. Compositional Analysis of HLW Glass by XRF (wt\%) (continued).

\begin{tabular}{|c|c|c|c|c|c|}
\hline & HWI-ALS-09 & HWI-ALS-10 & HWI-ALS-11 & HWI-ALS-12 & HWI-ALS-13 \\
\hline $\mathrm{Al}_{2} \mathrm{O}_{3}$ & $17.26 \%$ & $17.67 \%$ & $16.49 \%$ & $16.53 \%$ & $17.18 \%$ \\
\hline $\mathrm{As}_{2} \mathrm{O}_{5}$ & - & - & - & - & - \\
\hline $\mathrm{B}_{2} \mathrm{O}_{3}{ }^{*}$ & $13.44 \%$ & $12.88 \%$ & $15.50 \%$ & $10.00 \%$ & $9.60 \%$ \\
\hline $\mathrm{BaO}$ & $0.10 \%$ & $0.11 \%$ & $0.07 \%$ & $0.10 \%$ & $0.13 \%$ \\
\hline $\mathrm{CaO}$ & $4.25 \%$ & $4.25 \%$ & $1.47 \%$ & $1.60 \%$ & $1.62 \%$ \\
\hline $\mathrm{Ce}_{2} \mathrm{O}_{3}$ & $0.14 \%$ & $0.14 \%$ & $0.12 \%$ & $0.12 \%$ & $0.12 \%$ \\
\hline $\mathrm{Cl}$ & $0.01 \%$ & $0.01 \%$ & $0.01 \%$ & $0.01 \%$ & - \\
\hline $\mathrm{CoO}$ & $0.01 \%$ & $0.01 \%$ & $0.01 \%$ & $0.01 \%$ & $0.01 \%$ \\
\hline $\mathrm{Cr}_{2} \mathrm{O}_{3}$ & $0.24 \%$ & $0.25 \%$ & $0.21 \%$ & $0.21 \%$ & $0.22 \%$ \\
\hline $\mathrm{CuO}$ & $0.07 \%$ & $0.07 \%$ & $0.06 \%$ & $0.06 \%$ & $0.06 \%$ \\
\hline $\mathrm{Er}_{2} \mathrm{O}_{3}$ & $0.02 \%$ & $0.02 \%$ & $0.02 \%$ & $0.02 \%$ & $0.01 \%$ \\
\hline $\mathrm{Fe}_{2} \mathrm{O}_{3}$ & $10.89 \%$ & $11.58 \%$ & $9.83 \%$ & $10.10 \%$ & $10.20 \%$ \\
\hline $\mathrm{Ga}_{2} \mathrm{O}_{3}$ & $0.00 \%$ & $0.00 \%$ & - & $0.00 \%$ & $0.00 \%$ \\
\hline $\mathrm{HfO}_{2}$ & $0.01 \%$ & $0.01 \%$ & $0.01 \%$ & $0.01 \%$ & - \\
\hline $\mathrm{Ho}_{2} \mathrm{O}_{3}$ & - & - & $0.01 \%$ & - & - \\
\hline $\mathrm{K}_{2} \mathrm{O}$ & $0.14 \%$ & $0.14 \%$ & $0.14 \%$ & $0.15 \%$ & $0.15 \%$ \\
\hline $\mathrm{Li}_{2} \mathrm{O}^{*}$ & $2.88 \%$ & $2.76 \%$ & $4.50 \%$ & $5.00 \%$ & $4.80 \%$ \\
\hline $\mathrm{MgO}$ & $0.13 \%$ & $0.17 \%$ & $0.19 \%$ & $0.18 \%$ & $0.13 \%$ \\
\hline $\mathrm{MnO}$ & $1.09 \%$ & $1.15 \%$ & $1.00 \%$ & $1.00 \%$ & $1.02 \%$ \\
\hline $\mathrm{Na}_{2} \mathrm{O}$ & $14.03 \%$ & $14.48 \%$ & $14.68 \%$ & $14.50 \%$ & $15.69 \%$ \\
\hline $\mathrm{NiO}$ & $0.18 \%$ & $0.20 \%$ & $0.17 \%$ & $0.17 \%$ & $0.17 \%$ \\
\hline $\mathrm{P}_{2} \mathrm{O}_{5}$ & $0.03 \%$ & $0.02 \%$ & $0.03 \%$ & $0.03 \%$ & $0.03 \%$ \\
\hline $\mathrm{PbO}$ & $0.04 \%$ & $0.05 \%$ & $0.03 \%$ & $0.04 \%$ & $0.04 \%$ \\
\hline $\mathrm{SO}_{3}$ & $0.09 \%$ & $0.10 \%$ & $0.09 \%$ & $0.08 \%$ & $0.09 \%$ \\
\hline $\mathrm{SiO}_{2}$ & $32.82 \%$ & $31.69 \%$ & $33.43 \%$ & $38.00 \%$ & $36.66 \%$ \\
\hline $\mathrm{Sm}_{2} \mathrm{O}_{5}$ & - & - & - & - & - \\
\hline $\mathrm{SnO}_{2}$ & $0.01 \%$ & $0.01 \%$ & $0.00 \%$ & - & - \\
\hline $\mathrm{SrO}$ & $0.01 \%$ & $0.01 \%$ & $0.00 \%$ & $0.01 \%$ & $0.01 \%$ \\
\hline $\mathrm{Tb}_{4} \mathrm{O}_{7}$ & - & - & $0.01 \%$ & - & $0.01 \%$ \\
\hline $\mathrm{TiO}_{2}$ & $1.78 \%$ & $1.87 \%$ & $1.66 \%$ & $1.73 \%$ & $1.75 \%$ \\
\hline $\mathrm{V}_{2} \mathrm{O}_{5}$ & - & - & - & $0.00 \%$ & - \\
\hline $\mathrm{Y}_{2} \mathrm{O}_{3}$ & - & - & $0.00 \%$ & $0.01 \%$ & $0.00 \%$ \\
\hline $\mathrm{ZnO}$ & $0.06 \%$ & $0.06 \%$ & $0.06 \%$ & $0.05 \%$ & $0.05 \%$ \\
\hline $\mathrm{ZrO}_{2}$ & $0.26 \%$ & $0.28 \%$ & $0.20 \%$ & $0.26 \%$ & $0.26 \%$ \\
\hline TOTAL & $100.0 \%$ & $100.0 \%$ & $100.0 \%$ & $100.0 \%$ & $100.0 \%$ \\
\hline
\end{tabular}

${ }^{*} \mathrm{~B}_{2} \mathrm{O}_{3}$ and $\mathrm{Li}_{2} \mathrm{O}$ are not measured by XRF; target values are used.

- Empty data field. 
Table 2.8. Canister Centerline Cooling (CCC) Heat Treatment Schedule.

\begin{tabular}{|c|c|}
\hline Step Number & Event \\
\hline \hline 1 & Increase temperature from $25^{\circ} \mathrm{C}$ at $10^{\circ} \mathrm{C} /$ minute to $1150^{\circ} \mathrm{C}$ \\
\hline 2 & Hold at $1150^{\circ} \mathrm{C}$ for 240 minutes \\
\hline 3 & Decrease temperature at $-8^{\circ} \mathrm{C} /$ minute to $926^{\circ} \mathrm{C}$ \\
\hline 4 & Hold at $926^{\circ} \mathrm{C}$ for 6 minutes \\
\hline 5 & Decrease temperature at $-1{ }^{\circ} \mathrm{C} /$ minute to $779^{\circ} \mathrm{C}$ \\
\hline 6 & Hold at $779^{\circ} \mathrm{C}$ for 168 minutes \\
\hline 7 & Decrease temperature at $-1{ }^{\circ} \mathrm{C} /$ minute to $715^{\circ} \mathrm{C}$ \\
\hline 8 & Hold at $715^{\circ} \mathrm{C}$ for 204 minutes \\
\hline 9 & Decrease temperature at $-1{ }^{\circ} \mathrm{C} /$ minute to $598^{\circ} \mathrm{C}$ \\
\hline 10 & Hold at $598^{\circ} \mathrm{C}$ for 252 minutes \\
\hline 11 & Decrease temperature at $-1{ }^{\circ} \mathrm{C} /$ minute to $490^{\circ} \mathrm{C}$ \\
\hline 12 & Hold at $490^{\circ} \mathrm{C}$ for 258 minutes \\
\hline 13 & Decrease temperature at $-1{ }^{\circ} \mathrm{C} /$ minute to $382^{\circ} \mathrm{C}$ \\
\hline 14 & Hold at $382^{\circ} \mathrm{C}$ for 444 minutes \\
\hline 15 & Decrease temperature at $-1{ }^{\circ} \mathrm{C} /$ minute to less than $70^{\circ} \mathrm{C}$ \\
\hline
\end{tabular}


Table 2.9. Characterization Data for the HLW Glasses Prepared with Glass Frit VS1.

\begin{tabular}{|c|c|c|c|c|c|}
\hline & Glass ID & HWI-ALS-01 & HWI-ALS-03 & HWI-ALS-07 & HWI-ALS-08 \\
\hline & Waste Loading & $45 \mathrm{wt} \%$ & $48 w t \%$ & $50 \mathrm{wt} \%$ & $52 \mathrm{wt} \%$ \\
\hline & As-Melted & None & None & None & $\mathrm{NA}^{(\mathrm{a})}$ \\
\hline 色 & Heat Treated $\left(950^{\circ} \mathrm{C}\right)$ & 0.3 (Spinel) & 0.6 (Spinel) & 0.3 (Spinel) & 0.6 (Spinel) \\
\hline$e^{0}$ & Heat Treated $\left(1050^{\circ} \mathrm{C}\right)$ & None & None & None & 0.1 (Spinel) \\
\hline & $\mathrm{CCC}$ & NA & 10.0 (Spinel) & 9.8 (Spinel) & 7.9 (Spinel) \\
\hline & $950^{\circ} \mathrm{C}$ & 195.3 & 184.4 & 187.6 & 191.2 \\
\hline & $1000^{\circ} \mathrm{C}$ & 110.2 & 104.5 & 105.9 & 108.2 \\
\hline$\stackrel{3}{=}$ & $1050^{\circ} \mathrm{C}$ & 66.8 & 63.2 & 63.6 & 65.0 \\
\hline $\int_{0}^{0}$ & $1100^{\circ} \mathrm{C}$ & 43.0 & 40.3 & 40.3 & 41.1 \\
\hline & $1150^{\circ} \mathrm{C}$ & 29.0 & 26.9 & 26.7 & 27.2 \\
\hline & $1200^{\circ} \mathrm{C}$ & 20.4 & 18.6 & 18.4 & 18.6 \\
\hline & $950^{\circ} \mathrm{C}$ & 0.170 & 0.177 & 0.179 & 0.182 \\
\hline & $1000^{\circ} \mathrm{C}$ & 0.216 & 0.227 & 0.228 & 0.234 \\
\hline छิ & $1050^{\circ} \mathrm{C}$ & 0.269 & 0.285 & 0.285 & 0.292 \\
\hline$\pi$ & $1100^{\circ} \mathrm{C}$ & 0.329 & 0.352 & 0.350 & 0.357 \\
\hline E⿱乛龰 & $1150^{\circ} \mathrm{C}$ & 0.396 & 0.428 & 0.425 & 0.428 \\
\hline & $1200^{\circ} \mathrm{C}$ & 0.468 & 0.514 & 0.508 & 0.503 \\
\hline$\Xi$ & B & NA & 1.018 & 0.856 & NA \\
\hline 农 & $\mathrm{Li}$ & NA & 0.966 & 0.709 & NA \\
\hline $\begin{array}{ll}E & 0 \\
0 & 0 \\
0 & 0\end{array}$ & $\mathrm{Na}$ & NA & 0.679 & 0.640 & NA \\
\hline & $\mathrm{Si}$ & NA & 0.310 & 0.309 & NA \\
\hline & B & NA & 1.921 & 1.704 & NA \\
\hline 证 & $\mathrm{Li}$ & NA & 1.625 & 1.290 & NA \\
\hline $\mid \begin{array}{l}E \\
0 \\
0\end{array}$ & $\mathrm{Na}$ & NA & 1.066 & 0.999 & NA \\
\hline & $\mathrm{Si}$ & NA & 0.317 & 0.331 & NA \\
\hline
\end{tabular}

NA - Not Analyzed. 
Table 2.10. Characterization Data for the HLW Glasses Prepared with Glass Frit VS2.

\begin{tabular}{|c|c|c|c|c|c|}
\hline & Glass ID & HWI-ALS-02 & HWI-ALS-04 & HWI-ALS-09 & HWI-ALS-10 \\
\hline & Waste Loading & $47 \mathrm{wt} \%$ & $50 \mathrm{wt} \%$ & $52 \mathrm{wt} \%$ & $54 \mathrm{wt} \%$ \\
\hline & As-Melted & NA & None & None & NA \\
\hline & Heat Treated $\left(950^{\circ} \mathrm{C}\right)$ & 0.2 (Spinel) & 0.3 (Spinel) & 1.0 (Spinel) & 0.8 (Spinel) \\
\hline 竎 웅 & Heat Treated $\left(1050^{\circ} \mathrm{C}\right)$ & None & None & None & 0.8 (Spinel) \\
\hline S & $\mathrm{CCC}$ & NA & $\begin{array}{c}9.5 \text { (Spinel) } \\
\text { Trace (Nepheline) }\end{array}$ & $\begin{array}{c}5.8 \text { (Spinel) } \\
2.4 \text { (Nepheline) }\end{array}$ & $\begin{aligned} & 6.2 \text { (Spinel) } \\
\approx & 6 \text { (Nepheline) }\end{aligned}$ \\
\hline & $950^{\circ} \mathrm{C}$ & NA & 230.2 & 245.4 & NA \\
\hline & $1000^{\circ} \mathrm{C}$ & NA & 124.9 & 132.6 & NA \\
\hline$\stackrel{2}{=}$ & $1050^{\circ} \mathrm{C}$ & NA & 72.6 & 77.1 & NA \\
\hline$\overbrace{0}^{0}$ & $1100^{\circ} \mathrm{C}$ & NA & 44.7 & 47.6 & NA \\
\hline & $1150^{\circ} \mathrm{C}$ & NA & 28.9 & 30.9 & NA \\
\hline & $1200^{\circ} \mathrm{C}$ & NA & 19.5 & 20.9 & NA \\
\hline & $950^{\circ} \mathrm{C}$ & NA & 0.165 & 0.158 & NA \\
\hline & $1000^{\circ} \mathrm{C}$ & NA & 0.215 & 0.206 & NA \\
\hline$\widehat{\bar{z}} \widehat{\Xi}$ & $1050^{\circ} \mathrm{C}$ & NA & 0.272 & 0.262 & NA \\
\hline$\pi$ & $1100^{\circ} \mathrm{C}$ & NA & 0.335 & 0.325 & NA \\
\hline 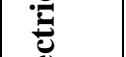 & $1150^{\circ} \mathrm{C}$ & NA & 0.404 & 0.396 & NA \\
\hline & $1200^{\circ} \mathrm{C}$ & NA & 0.479 & 0.473 & NA \\
\hline 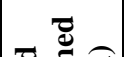 & B & NA & 0.616 & 0.722 & NA \\
\hline 苋 & $\mathrm{Li}$ & NA & 0.597 & 0.691 & NA \\
\hline E 0 & $\mathrm{Na}$ & NA & 0.630 & 0.735 & NA \\
\hline & $\mathrm{Si}$ & NA & 0.252 & 0.262 & NA \\
\hline & B & NA & 0.625 & 6.533 & NA \\
\hline U & $\mathrm{Li}$ & NA & 0.571 & 5.215 & NA \\
\hline $\mid \begin{array}{l}E \\
\vdots \\
0\end{array}$ & $\mathrm{Na}$ & NA & 0.520 & 2.362 & NA \\
\hline & $\mathrm{Si}$ & NA & 0.193 & 0.209 & NA \\
\hline
\end{tabular}

NA - Not Analyzed. 
Table 2.11. Characterization Data for the HLW Glasses Prepared with Glass Frits VS3 and VS4.

\begin{tabular}{|c|c|c|c|c|c|c|}
\hline & Glass ID & HWI-ALS-05 & HWI-ALS-06 & HWI-ALS-11 & HWI-ALS-12 & HWI-ALS-13 \\
\hline & Waste Loading & $\begin{array}{c}48 \mathrm{wt} \% \\
(\mathrm{VS} 3)\end{array}$ & $\begin{array}{l}48 w t \% \\
\text { (VS4) }\end{array}$ & $\begin{array}{c}50 \mathrm{wt} \% \\
\text { (VS4) }\end{array}$ & $\begin{array}{c}50 \mathrm{wt} \% \\
(\mathrm{VS} 3)\end{array}$ & $\begin{array}{c}52 \mathrm{wt} \% \\
\text { (VS3) }\end{array}$ \\
\hline & As-Melted & None & None & NA & NA & NA \\
\hline 竎 & Heat Treated $\left(950^{\circ} \mathrm{C}\right)$ & 0.3 (Spinel) & 0.2 (Spinel) & NA & 0.2 (Spinel) & 0.9 (Spinel) \\
\hline $2 \geq$ & Heat Treated $\left(1050^{\circ} \mathrm{C}\right)$ & None & None & NA & None & None \\
\hline & $\mathrm{CCC}$ & 0.6 (Spinel) & 2.2 (Spinel) & 9.2 (Spinel) & $\begin{array}{c}10.5(\text { Spinel })+ \\
\text { Nepheline }(\approx 20 \%)\end{array}$ & $\begin{array}{c}5.3 \text { (Spinel) }+ \\
\text { Nepheline }(\approx 20 \%)\end{array}$ \\
\hline & $950^{\circ} \mathrm{C}$ & 243.6 & 118.8 & NA & NA & NA \\
\hline & $1000^{\circ} \mathrm{C}$ & 138.8 & 69.9 & NA & NA & NA \\
\hline$\stackrel{3}{=}$ & $1050^{\circ} \mathrm{C}$ & 84.0 & 43.8 & NA & NA & NA \\
\hline$\underbrace{0}_{0}$ & $1100^{\circ} \mathrm{C}$ & 53.5 & 28.9 & NA & NA & NA \\
\hline$>$ & $1150^{\circ} \mathrm{C}$ & 35.6 & 19.9 & NA & NA & NA \\
\hline & $1200^{\circ} \mathrm{C}$ & 24.6 & 14.2 & NA & NA & NA \\
\hline & $950^{\circ} \mathrm{C}$ & 0.231 & 0.249 & NA & NA & NA \\
\hline 至 & $1000^{\circ} \mathrm{C}$ & 0.294 & 0.314 & NA & NA & NA \\
\hline छิ & $1050^{\circ} \mathrm{C}$ & 0.362 & 0.389 & NA & NA & NA \\
\hline 氜 & $1100^{\circ} \mathrm{C}$ & 0.436 & 0.475 & NA & NA & NA \\
\hline 跤 & $1150^{\circ} \mathrm{C}$ & 0.514 & 0.571 & NA & NA & NA \\
\hline & $1200^{\circ} \mathrm{C}$ & 0.595 & 0.679 & NA & NA & NA \\
\hline ت्ञ & B & 0.578 & 1.196 & NA & NA & NA \\
\hline 芯 & $\mathrm{Li}$ & 0.609 & 0.955 & NA & NA & NA \\
\hline 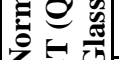 & $\mathrm{Na}$ & 0.532 & 0.829 & NA & NA & NA \\
\hline 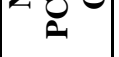 & $\mathrm{Si}$ & 0.375 & 0.328 & NA & NA & NA \\
\hline & B & 1.340 & 1.293 & NA & NA & NA \\
\hline 赵讨 & $\mathrm{Li}$ & 1.129 & 1.118 & NA & NA & NA \\
\hline E⿱ & $\mathrm{Na}$ & 0.721 & 0.867 & NA & NA & NA \\
\hline & $\mathrm{Si}$ & 0.393 & 0.358 & NA & NA & NA \\
\hline
\end{tabular}

NA - Not Analyzed. 
Table 2.12. Recipe for Co-Precipitated SB19 Sludge Simulant [20].

\begin{tabular}{|c|c|c|}
\hline Step & Starting Material & Weight (g) \\
\hline \multirow{8}{*}{ 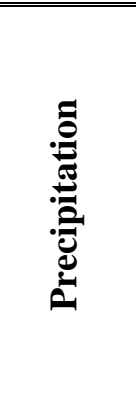 } & Water & 345.4 \\
\hline & $\mathrm{Mn}\left(\mathrm{NO}_{3}\right)_{2}(50 \%$ Solution $)$ & 7.40 \\
\hline & $\mathrm{KMnO}_{4}$ & 2.16 \\
\hline & $\mathrm{Fe}\left(\mathrm{NO}_{3}\right)_{3} \cdot 9 \mathrm{H}_{2} \mathrm{O}$ & 128.27 \\
\hline & $\mathrm{Ni}\left(\mathrm{NO}_{3}\right)_{2} \cdot 6 \mathrm{H}_{2} \mathrm{O}$ & 1.69 \\
\hline & Water & 203.45 \\
\hline & $\mathrm{NaOH}(50 \%)$ & Target $\mathrm{pH}=10$ \\
\hline & \multicolumn{2}{|c|}{ Settle and decant supernate } \\
\hline \multirow{4}{*}{ 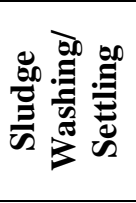 } & \multicolumn{2}{|c|}{ Wash with $\mathrm{NaOH} / \mathrm{NaNO}_{2}$ solution to remove excess nitrate } \\
\hline & $\mathrm{NaOH}$ & 0.32 \\
\hline & $\mathrm{NaNO}_{2}$ & 0.55 \\
\hline & Water & 8000 \\
\hline \multirow{25}{*}{ 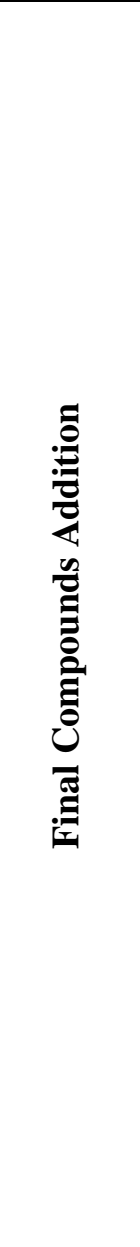 } & $\mathrm{NaAlO}_{2}$ & 5.11 \\
\hline & $\mathrm{Al}(\mathrm{OH})_{3}$ & 66.28 \\
\hline & $\mathrm{BaO}$ & 0.25 \\
\hline & $\mathrm{CaCO}_{3}$ & 6.86 \\
\hline & $\mathrm{Ce}\left(\mathrm{NO}_{3}\right)_{3} \cdot 6 \mathrm{H}_{2} \mathrm{O}$ & 0.70 \\
\hline & $\mathrm{Cr}_{2} \mathrm{O}_{3}$ & 0.44 \\
\hline & $\mathrm{CuO}$ & 0.12 \\
\hline & $\mathrm{KOH}$ & 0.34 \\
\hline & $\mathrm{La}\left(\mathrm{NO}_{3}\right)_{3} \cdot 6 \mathrm{H}_{2} \mathrm{O}$ & 0.38 \\
\hline & $\mathrm{MgO}$ & 0.51 \\
\hline & $\mathrm{Na}_{2} \mathrm{CO}_{3}$ & 1.82 \\
\hline & $\mathrm{Na}_{2} \mathrm{SO}_{4}$ & 0.33 \\
\hline & $\mathrm{Na}_{3} \mathrm{PO}_{4} \cdot 6 \mathrm{H}_{2} \mathrm{O}$ & 0.29 \\
\hline & $\mathrm{NaF}$ & 0.02 \\
\hline & $\mathrm{NaCl}$ & 0.04 \\
\hline & $\mathrm{NaNO}_{2}$ & 23.64 \\
\hline & $\mathrm{NaNO}_{3}$ & 14.93 \\
\hline & $\mathrm{NaOH}$ & 25.09 \\
\hline & $\mathrm{NaC}_{2} \mathrm{O}_{4}$ & 0.11 \\
\hline & $\mathrm{PbO}$ & 0.09 \\
\hline & $\mathrm{SiO}_{2}$ & 11.21 \\
\hline & $\mathrm{SrO}$ & 0.00 \\
\hline & $\mathrm{TiO}_{2}$ & 4.20 \\
\hline & $\mathrm{ZnO}$ & 0.12 \\
\hline & $\mathrm{ZrO}_{2}$ & 0.64 \\
\hline
\end{tabular}


Table 2.13. Analyses of the Co-Precipitated SB19 Sludge Simulant.

\begin{tabular}{|c|c|}
\hline Property & Result \\
\hline \hline Sludge Mass & $3251.35 \mathrm{~kg}$ \\
\hline Sludge Wt\% Total Solids & $12.26 \mathrm{wt} \%$ \\
\hline Sludge Wt\% Calcined Solids & $8.86 \mathrm{wt} \%$ \\
\hline Sludge Density & $1.08 \mathrm{~g} / \mathrm{ml}$ \\
\hline Sludge Nitrite & $14137 \mathrm{mg} / \mathrm{kg}$ slurry \\
\hline Sludge Nitrate & $8768 \mathrm{mg} / \mathrm{kg}$ slurry \\
\hline Sludge Formate & $0 \mathrm{mg} / \mathrm{kg}$ slurry \\
\hline Sludge Carbon & $442 \mathrm{mg} / \mathrm{kg}$ slurry \\
\hline Sludge Manganese & $1.25 \mathrm{wt} \%$ (calcined basis) \\
\hline Sludge TIC (as carbonate) & $347 \mathrm{mg} / \mathrm{kg}$ slurry \\
\hline Sludge Hydroxide (Base Eqts) $\mathrm{pH}=7$ & $0.400 \mathrm{equivalent} \mathrm{mole/1} \mathrm{slurry}$ \\
\hline Sludge Mercury & $0 \mathrm{mg} / \mathrm{kg}$ slurry \\
\hline
\end{tabular}

Table 2.14. Analytical Data for SRAT Product.

\begin{tabular}{|c|c|}
\hline Analyte & Concentration (mg/kg slurry) \\
\hline Nitrite & 84 \\
\hline Nitrate & 47120 \\
\hline Formate & 93343 \\
\hline
\end{tabular}


Table 2.15. Composition of the Direct-Hydroxide Simulant (Oxide Content $=136.52$ g).

\begin{tabular}{|c|c|}
\hline Starting Material & Weight (g) \\
\hline $\mathrm{Al}(\mathrm{OH})_{3}$ & 66.280 \\
\hline $\mathrm{BaO}$ & 0.250 \\
\hline $\mathrm{CaO}$ & 3.844 \\
\hline $\mathrm{Ce}\left(\mathrm{NO}_{3}\right)_{3} \cdot 6 \mathrm{H}_{2} \mathrm{O}$ & 0.700 \\
\hline $\mathrm{Cr}_{2} \mathrm{O}_{3}$ & 0.440 \\
\hline $\mathrm{CuO}$ & 0.120 \\
\hline $\mathrm{Fe}(\mathrm{OH})_{3}(13 \%$ slurry $)$ & 260.967 \\
\hline HCOONa & 80.082 \\
\hline $\mathrm{KNO}_{3}$ & 1.995 \\
\hline $\mathrm{La}\left(\mathrm{NO}_{3}\right)_{3} \cdot 6 \mathrm{H} 2 \mathrm{O}$ & 0.380 \\
\hline $\mathrm{MgO}$ & 0.510 \\
\hline $\mathrm{MnO}$ & 2.436 \\
\hline $\mathrm{NaAlO}_{2}$ & 5.110 \\
\hline $\mathrm{NaCl}$ & 0.040 \\
\hline $\mathrm{NaF}$ & 0.020 \\
\hline $\mathrm{NaNO}_{2}$ & 0.082 \\
\hline $\mathrm{Na}_{2} \mathrm{SO}_{4}$ & 0.330 \\
\hline $\mathrm{Na}_{3} \mathrm{PO}_{4} \cdot 12 \mathrm{H}_{2} \mathrm{O}$ & 0.290 \\
\hline $\mathrm{Na}_{2} \mathrm{C}_{2} \mathrm{O}_{4}$ & 0.110 \\
\hline $\mathrm{NiO}$ & 0.434 \\
\hline $\mathrm{PbO}$ & 0.090 \\
\hline $\mathrm{SiO}_{2}$ & 11.210 \\
\hline $\mathrm{TiO}_{2}$ & 4.200 \\
\hline $\mathrm{ZnO}$ & 0.120 \\
\hline $\mathrm{ZrO}_{2}$ & 0.640 \\
\hline Concentrated $\mathrm{HNO}_{3}$ & 41.939 \\
\hline Concentrated $\mathrm{HCOOH}$ & 8.577 \\
\hline Water & 210 \\
\hline
\end{tabular}


Table 4.1. Summary of Results from DM100 Tests with SRS SB19 Simulant Prepared by Harrell Industries.

\begin{tabular}{|c|c|c|c|c|}
\hline \multicolumn{2}{|r|}{ Test } & 1 & 2 & 3 \\
\hline \multirow{3}{*}{$\underset{\boxminus}{\Xi}$} & Feed Start & $6 / 2 / 1023: 52$ & $6 / 9 / 1000: 00$ & $6 / 16 / 1008: 30$ \\
\hline & Feed End & $6 / 5 / 102: 00$ & $6 / 11 / 102: 30$ & $6 / 18 / 1011: 15$ \\
\hline & Interval & $50.1 \mathrm{hr}$ & $50.5 \mathrm{hr}$ & $50.75 \mathrm{hr}$ \\
\hline \multicolumn{2}{|r|}{ Water Feeding for Cold Cap } & $0.5 \mathrm{hr}$ & $0 \mathrm{hr}$ & $0.75 \mathrm{hr}$ \\
\hline \multicolumn{2}{|r|}{ Slurry Feeding } & $49.6 \mathrm{hr}$ & $50.5 \mathrm{hr}$ & $50.0 \mathrm{hr}$ \\
\hline \multicolumn{2}{|r|}{ Feeding Interruptions } & $136 \min$ & $14 \min$ & $40 \mathrm{~min}$ \\
\hline \multicolumn{2}{|r|}{ Cold Cap Burn-Off } & $1.6 \mathrm{hr}$ & $1.9 \mathrm{hr}$ & $1.3 \mathrm{hr}$ \\
\hline \multicolumn{2}{|r|}{ Plenum Heaters } & $\mathrm{ON}$ & $\mathrm{ON}$ & $\mathrm{ON}$ \\
\hline \multicolumn{2}{|c|}{ Average Measured Plenum Temperature } & $675^{\circ} \mathrm{C}^{\&}$ & $632^{\circ} \mathrm{C}$ & $688^{\circ} \mathrm{C}$ \\
\hline \multicolumn{2}{|r|}{ Target Glass Temperature } & $1150^{\circ} \mathrm{C}$ & $1150^{\circ} \mathrm{C}$ & $1150^{\circ} \mathrm{C}$ \\
\hline \multicolumn{2}{|c|}{ Average Measured Bulk Glass Temperature } & $1149^{\circ} \mathrm{C}^{\&}$ & $1155^{\circ} \mathrm{C}$ & $1150^{\circ} \mathrm{C}$ \\
\hline \multirow{3}{*}{ Bubbling } & Gas & Air & None & Argon \\
\hline & Target Rate & $\begin{array}{l}\text { To achieve glass } \\
\text { production rate of } \\
1125 \mathrm{~kg} / \mathrm{m}^{2} / \text { day }\end{array}$ & $\begin{array}{c}0 \\
\text { (No bubbling) }\end{array}$ & $\begin{array}{l}\text { To achieve glass } \\
\text { production rate of } \\
1125 \mathrm{~kg} / \mathrm{m}^{2} / \text { day }\end{array}$ \\
\hline & Average Rate & $11.8 \mathrm{lpm}^{\&}$ & $0 \mathrm{lpm}$ & $11.9 \mathrm{lpm}$ \\
\hline \multirow{2}{*}{ Feed } & Used & $705 \mathrm{~kg}$ & $288 \mathrm{~kg}$ & $712 \mathrm{~kg}$ \\
\hline & Average Feed Rate & $14.2 \mathrm{~kg} / \mathrm{hr}$ & $5.7 \mathrm{~kg} / \mathrm{hr}$ & $14.2 \mathrm{~kg} / \mathrm{hr}$ \\
\hline \multirow{6}{*}{ Glass } & Poured & $279.5 \mathrm{~kg}$ & $74.7 \mathrm{~kg}$ & $257.5 \mathrm{~kg}$ \\
\hline & Average Rate ${ }^{\$}$ & $1252 \mathrm{~kg} / \mathrm{m}^{2} /$ day & $329 \mathrm{~kg} / \mathrm{m}^{2} /$ day & $1144 \mathrm{~kg} / \mathrm{m}^{2} /$ day \\
\hline & Average Rate ${ }^{*}$ & $1134 \mathrm{~kg} / \mathrm{m}^{2} /$ day & $450 \mathrm{~kg} / \mathrm{m}^{2} /$ day & $1133 \mathrm{~kg} / \mathrm{m}^{2} /$ day \\
\hline & Estimated Steady State Rate ${ }^{*}$ & $1200 \mathrm{~kg} / \mathrm{m}^{2} /$ day $^{\&}$ & $400 \mathrm{~kg} / \mathrm{m}^{2} /$ day & $1125 \mathrm{~kg} / \mathrm{m}^{2} /$ day \\
\hline & Measured $\% \mathrm{Fe}^{++} /$Total Fe & $<1$ & $<1$ & 18 \\
\hline & Average Power Use (kW.hr/kg glass) & 4.8 & 6.9 & 4.6 \\
\hline
\end{tabular}

$\$$ - Rates calculated from glass poured. *- Rates calculated from feed data.

\& - Value calculated from portion of Test 1 conducted after feed diluted to $45 \%$ solids.

Note: Rates do not take into account the time for water feeding and cold cap burn-off. 
Table 4.2. Summary of Results from DM100 Tests with SRS SB19 Simulant Prepared by NOAH.

\begin{tabular}{|c|c|c|c|}
\hline \multicolumn{2}{|r|}{ Test } & 4 & 5 \\
\hline \multirow{3}{*}{$\stackrel{\mathscr{\Xi}}{\Xi}$} & Feed Start & $7 / 12 / 109: 30$ & $7 / 14 / 1012: 30$ \\
\hline & Feed End & 7/14/10 12:00 & $7 / 16 / 1020: 00$ \\
\hline & Interval & $50.5 \mathrm{hr}$ & $55.5 \mathrm{hr}$ \\
\hline \multicolumn{2}{|r|}{ Water Feeding for Cold Cap } & $0.5 \mathrm{hr}$ & $0 \mathrm{hr}$ \\
\hline \multicolumn{2}{|r|}{ Slurry Feeding } & $50.0 \mathrm{hr}$ & $55.5 \mathrm{hr}$ \\
\hline \multicolumn{2}{|r|}{ Feeding Interruptions } & $29 \min$ & $213 \mathrm{~min}$ \\
\hline \multicolumn{2}{|r|}{ Cold Cap Burn-Off } & Not Applicable & $1.8 \mathrm{hr}$ \\
\hline \multicolumn{2}{|r|}{ Plenum Heaters } & $\mathrm{ON}$ & $\mathrm{ON}$ \\
\hline \multicolumn{2}{|c|}{ Average Measured Plenum Temperature } & $685^{\circ} \mathrm{C}$ & $679^{\circ} \mathrm{C}$ \\
\hline \multicolumn{2}{|r|}{ Target Glass Temperature } & $1150^{\circ} \mathrm{C}$ & $1150^{\circ} \mathrm{C}$ \\
\hline \multicolumn{2}{|c|}{ Average Measured Bulk Glass Temperature } & $1151^{\circ} \mathrm{C}$ & $1154^{\circ} \mathrm{C}$ \\
\hline \multirow{3}{*}{ Bubbling } & Gas & Air & None \\
\hline & Target Rate & $\begin{array}{l}\text { To achieve glass production } \\
\text { rate of } 1125 \mathrm{~kg} / \mathrm{m}^{2} / \text { day }\end{array}$ & $\begin{array}{c}0 \\
\text { (No bubbling) }\end{array}$ \\
\hline & Average Rate & $8.5 \mathrm{lpm}$ & $0 \mathrm{lpm}$ \\
\hline \multirow{2}{*}{ Feed } & Used & $755 \mathrm{~kg}$ & $287 \mathrm{~kg}$ \\
\hline & Average Feed Rate & $15.1 \mathrm{~kg} / \mathrm{hr}$ & $5.2 \mathrm{~kg} / \mathrm{hr}$ \\
\hline \multirow{6}{*}{ Glass } & Poured & $260.1 \mathrm{~kg}$ & $93.5 \mathrm{~kg}$ \\
\hline & Average Rate ${ }^{\$}$ & $1145 \mathrm{~kg} / \mathrm{m}^{2} /$ day & $371 \mathrm{~kg} / \mathrm{m}^{2} /$ day \\
\hline & Average Rate ${ }^{*}$ & $1124 \mathrm{~kg} / \mathrm{m}^{2} /$ day & $385 \mathrm{~kg} / \mathrm{m}^{2} /$ day \\
\hline & Estimated Steady State Rate ${ }^{*}$ & $1125 \mathrm{~kg} / \mathrm{m}^{2} /$ day $^{\&}$ & $400 \mathrm{~kg} / \mathrm{m}^{2} /$ day \\
\hline & Measured $\% \mathrm{Fe}++/$ Total $\mathrm{Fe}$ & $<1$ & 4.6 \\
\hline & Average Power Use (kW.hr/kg glass) & 5.2 & 8.8 \\
\hline
\end{tabular}

$\$$ - Rates calculated from glass poured.

*- Rates calculated from feed data.

Note: Rates do not take into account the time for water feeding and cold cap burn-off. 
Table 4.3. Steady-State Production Rates Achieved on the DM100 Melter with Various HLW Compositions Processed at $1150{ }^{\circ} \mathrm{C}$ with Optimized Bubbling and Without Bubbling.

\begin{tabular}{|c|c|c|c|c|c|c|}
\hline $\begin{array}{l}\text { Bubbling } \\
\text { Strategy }\end{array}$ & HLW Waste & $\begin{array}{l}\text { Additive } \\
\text { Forms }\end{array}$ & $\begin{array}{c}\text { Glass Yield } \\
(\mathrm{g} / \mathrm{L})\end{array}$ & $\begin{array}{l}\text { Plenum } \\
\text { Heaters } \\
\end{array}$ & $\begin{array}{c}\text { Bubbling }^{*} \\
\text { (lpm) }\end{array}$ & $\begin{array}{c}\text { Production Rate } \\
\mathrm{kg} / \mathrm{m}^{2} / \text { day }\end{array}$ \\
\hline \multirow{3}{*}{$\begin{array}{c}\text { Targeting } \\
1125 \\
\mathrm{~kg} / \mathrm{m}^{2} / \text { day }\end{array}$} & $\begin{array}{l}\text { SRS SB19 Co- } \\
\text { precipitated }\end{array}$ & Frit & 475 & $\mathrm{ON}$ & 11.8 & 1200 \\
\hline & $\begin{array}{l}\text { SRS SB19 Co- } \\
\text { precipitated }\end{array}$ & Frit & 475 & $\mathrm{ON}$ & 11.9 Argon & 1125 \\
\hline & $\begin{array}{c}\text { SRS SB19 Direct } \\
\text { hydroxide }\end{array}$ & Frit & 438 & $\mathrm{ON}$ & 8.5 & 1125 \\
\hline \multirow{5}{*}{ Optimized } & SRS Batch 4 [32] & Frit & 460 & OFF & 15.3 & 1650 \\
\hline & $\begin{array}{c}\text { SRS Batch 4with } \\
\text { SWPF Products } \\
{[32]}\end{array}$ & Frit & 460 & OFF & 15.5 & 1675 \\
\hline & $\begin{array}{l}\text { Aluminum } \\
\text { Limited [4] }\end{array}$ & $\begin{array}{c}\text { Reagent } \\
\text { Chemicals, } \\
\text { Minerals }\end{array}$ & 500 & OFF & 16.6 & 1000 \\
\hline & $\begin{array}{c}\text { Aluminum and } \\
\text { Sodium Limited } \\
{[4]}\end{array}$ & $\begin{array}{c}\text { Reagent } \\
\text { Chemicals, } \\
\text { Minerals }\end{array}$ & 500 & OFF & 15.0 & 1250 \\
\hline & $\begin{array}{c}\text { C-106/AY-102, } \\
\text { High Waste } \\
\text { Loading [18] }\end{array}$ & $\begin{array}{c}\text { Reagent } \\
\text { Chemicals, } \\
\text { Minerals } \\
\end{array}$ & 420 & OFF & 11.3 & 1350 \\
\hline \multirow{8}{*}{$\begin{array}{c}0-0.3 \\
\mathrm{lpm}\end{array}$} & $\begin{array}{l}\text { SRS SB19 Co- } \\
\text { precipitated }\end{array}$ & Frit & 475 & $\mathrm{ON}$ & 0 & 400 \\
\hline & $\begin{array}{c}\text { SRS SB19 Direct } \\
\text { hydroxide }\end{array}$ & Frit & 438 & $\mathrm{ON}$ & 0 & 400 \\
\hline & SRS SB3 [32] & Frit & 470 & $\mathrm{ON}$ & 0 & 400 \\
\hline & SRS SB4 [32] & Frit & 460 & OFF & $<0.3$ & 450 \\
\hline & AZ-101 & Frit & 570 & OFF & $<0.3$ & 650 \\
\hline & AZ-101 [8] & $\begin{array}{c}\text { Reagent } \\
\text { Chemicals, } \\
\text { Minerals } \\
\end{array}$ & $350-540$ & OFF & $<0.3$ & $350-430$ \\
\hline & $\begin{array}{c}\text { Nitrated AZ-101 } \\
{[8]}\end{array}$ & $\begin{array}{l}\text { Reagent } \\
\text { Chemicals, } \\
\text { Minerals }\end{array}$ & 420 & OFF & $<0.3$ & 490 \\
\hline & AZ-101[8] & $\begin{array}{c}\text { Reagent } \\
\text { Chemicals, } \\
\text { Minerals }\end{array}$ & 540 & $\mathrm{ON}$ & $<0.3$ & 530 \\
\hline
\end{tabular}

* Air unless otherwise noted 
Table 4.4. Summary of Measured DM100 Parameters for SRS SB19 Tests.

\begin{tabular}{|c|c|c|c|c|c|c|c|c|c|c|c|c|c|c|c|c|c|}
\hline \multirow{2}{*}{\multicolumn{3}{|c|}{ Test }} & \multicolumn{3}{|c|}{$1 *$} & \multicolumn{3}{|c|}{2} & \multicolumn{3}{|c|}{3} & \multicolumn{3}{|c|}{4} & \multicolumn{3}{|c|}{5} \\
\hline & & & $\mathrm{AVG}$ & MIN & MAX & $\mathrm{AVG}$ & MIN & MAX & $\mathrm{AVG}$ & MIN & MAX & $\mathrm{AVG}$ & MIN & MAX & $\mathrm{AVG}$ & MIN & MAX \\
\hline \multirow{4}{*}{ Electrode } & \multirow{4}{*}{ Electrode } & East Upper & 1087 & 1051 & 1117 & 984 & 952 & 1052 & 1078 & 1038 & 1093 & 1080 & 1051 & 1098 & 1039 & 1010 & 1082 \\
\hline & & West Upper & 1051 & 1028 & 1078 & 951 & 919 & 1027 & 1042 & 1027 & 1066 & ND & ND & ND & 997 & 974 & 1017 \\
\hline & & West Lower & 1061 & 1037 & 1080 & 1066 & 1059 & 1078 & 1062 & 1047 & 1082 & 1071 & 1048 & 1083 & 1072 & 1059 & 1083 \\
\hline & & Bottom & 700 & 695 & 704 & 919 & 908 & 993 & 739 & 727 & 793 & 682 & 647 & 696 & 881 & 758 & 963 \\
\hline $\begin{array}{l}P \\
F\end{array}$ & \multirow{4}{*}{ Glass } & 27 " from bottom & 1136 & 1049 & 1175 & 1052 & 388 & 1161 & 1137 & 1076 & 1163 & 1138 & 1092 & 1161 & 1123 & 1046 & 1168 \\
\hline $\begin{array}{l}\mathrm{L} \\
\mathrm{R}\end{array}$ & & $16 "$ from bottom & 1143 & 1103 & 1176 & 1152 & 1142 & 1190 & 1142 & 1104 & 1179 & 1146 & 1123 & 1172 & 1153 & 1130 & 1176 \\
\hline A & & $10 "$ from bottom & 1156 & 1117 & 1191 & 1161 & 1151 & 1195 & 1156 & 1128 & 1188 & 1157 & 1133 & 1178 & 1160 & 1138 & 1184 \\
\hline $\mathrm{T}$ & & $5 "$ from bottom & 1149 & 1112 & 1181 & 1151 & 1142 & 1181 & 1151 & 1128 & 1177 & 1149 & 1127 & 1168 & 1148 & 1126 & 1166 \\
\hline U & \multirow{2}{*}{ Plenum } & Exposed & 688 & 583 & 775 & 636 & 573 & 877 & 697 & 571 & 765 & 696 & 608 & 771 & 691 & 635 & 808 \\
\hline \multirow{5}{*}{$\begin{array}{c}E \\
(C)\end{array}$} & & Thermowell & 662 & 598 & 731 & 627 & 592 & 860 & 678 & 612 & 742 & 673 & 626 & 750 & 667 & 623 & 768 \\
\hline & \multirow{2}{*}{ Discharge } & Chamber & 975 & 954 & 1012 & 986 & 960 & 1013 & 1008 & 925 & 1045 & 1002 & 785 & 1049 & 1020 & 1001 & 1052 \\
\hline & & Air Lift & 988 & 959 & 1122 & 977 & 956 & 1083 & 999 & 913 & 1096 & 981 & 798 & 1087 & 997 & 983 & 1126 \\
\hline & \multicolumn{2}{|c|}{ Film Cooler Outlet } & 310 & 204 & 343 & 311 & 242 & 321 & 288 & 177 & 318 & 288 & 274 & 344 & 283 & 275 & 289 \\
\hline & \multicolumn{2}{|c|}{ Transition Line Outlet } & 298 & 209 & 320 & 297 & 255 & 301 & 277 & 183 & 293 & 286 & 227 & 339 & 276 & 214 & 281 \\
\hline \multicolumn{3}{|c|}{ Lance Bubbling (lpm) } & 11.8 & 3.2 & 20.5 & 0 & 0 & 0 & 11.9 & 0.3 & 20.7 & 8.5 & 1.2 & 12.2 & 0 & 0 & 0 \\
\hline \multicolumn{3}{|c|}{ Melter Pressure (inches water) } & -1.22 & -2.20 & 7.88 & -0.96 & -1.23 & 0.32 & -1.17 & -2.31 & 1.72 & -0.98 & -1.71 & 0.15 & -0.93 & -1.41 & -0.13 \\
\hline \multicolumn{3}{|c|}{ Total Electrode Voltage (V) } & 38.0 & 31.0 & 49.2 & 21.6 & 20.4 & 25.5 & 36.1 & 30.1 & 41.1 & 34.7 & 30.9 & 37.2 & 22.7 & 19.2 & 24.9 \\
\hline \multicolumn{3}{|c|}{ Total Electrode Power $(\mathrm{kW})$} & 22.3 & 14.5 & 29.4 & 11.7 & 11.0 & 17.8 & 21.2 & 17.1 & 24.3 & 21.4 & 17.3 & 23.7 & 12.9 & 11.2 & 15.3 \\
\hline \multicolumn{3}{|c|}{ Plenum Heater Power $(\mathrm{kW})$} & 2.5 & 2.5 & 2.5 & 2.5 & 2.5 & 2.5 & 2.5 & 2.5 & 2.5 & 2.5 & 2.5 & 2.5 & 2.5 & 2.5 & 2.5 \\
\hline \multicolumn{3}{|c|}{ Total Power $(\mathrm{kW})$} & 24.8 & 17.0 & 31.9 & 14.2 & 13.5 & 20.3 & 23.7 & 19.6 & 26.8 & 23.9 & 19.8 & 26.2 & 15.4 & 13.7 & 17.8 \\
\hline \multicolumn{3}{|c|}{ Glass Resistance (ohms) } & 0.065 & 0.055 & 0.086 & 0.040 & 0.035 & 0.043 & 0.062 & 0.053 & 0.071 & 0.056 & 0.052 & 0.062 & 0.040 & 0.030 & 0.046 \\
\hline
\end{tabular}

* - Values calculated from the latter portion of the test after feed solids content diluted to 45 weight percent solids.

ND - No data available. 
Table 5.1. XRF and DCP Analyzed Compositions of Glass Frit Used for SRS DM100 Tests (wt \%).

\begin{tabular}{|c|c|c|c|}
\hline Oxide & Target & XRF & DCP \\
\hline $\mathrm{Al}_{2} \mathrm{O}_{3}$ & - & 0.14 & 0.18 \\
\hline $\mathrm{B}_{2} \mathrm{O}_{3}$ & 20.00 & $20.00^{*}$ & 19.33 \\
\hline $\mathrm{BaO}$ & - & 0.02 & 0.01 \\
\hline $\mathrm{CaO}$ & - & 0.04 & 0.05 \\
\hline $\mathrm{Cl}$ & - & 0.01 & NA \\
\hline $\mathrm{Cr}_{2} \mathrm{O}_{3}$ & - & $<0.01$ & $<0.01$ \\
\hline $\mathrm{CuO}$ & - & $<0.01$ & $<0.01$ \\
\hline $\mathrm{Fe}_{2} \mathrm{O}_{3}$ & - & $<0.01$ & 0.05 \\
\hline $\mathrm{K}_{2} \mathrm{O}$ & - & $<0.01$ & 0.03 \\
\hline $\mathrm{Li}_{2} \mathrm{O}$ & 10.00 & $10.00 *$ & 9.15 \\
\hline $\mathrm{MgO} \mathrm{O}$ & - & $<0.01$ & 0.01 \\
\hline $\mathrm{MnO}_{\mathrm{Na}} \mathrm{O}$ & - & $<0.01$ & $<0.01$ \\
\hline $\mathrm{NiO}_{2}$ & - & $<0.01$ & 0.06 \\
\hline $\mathrm{P}_{2} \mathrm{O}_{5}$ & - & $<0.01$ & 0.01 \\
\hline $\mathrm{PbO}_{\mathrm{SiO}}$ & - & $<0.01$ & 0.18 \\
\hline $\mathrm{SiO}_{2}$ & 70.00 & 60.01 & 0.02 \\
\hline $\mathrm{SO}_{3}$ & - & 0.04 & 67.04 \\
\hline $\mathrm{TiO}_{2}$ & - & 0.01 & NA \\
\hline $\mathrm{ZnO}_{\mathrm{ZrO}}$ & - & $<0.01$ & $<0.02$ \\
\hline $\mathrm{Sum}_{2}$ & - & $<0.01$ & 0.01 \\
\hline & 100.00 & 100.00 & 96.15 \\
\hline
\end{tabular}

* Target values

NA - Not analyzed

- Empty data field. 
Table 5.2. Characteristics of Feed Samples Taken During DM100 Tests.

\begin{tabular}{|c|c|c|c|c|c|c|c|c|c|}
\hline \multirow{2}{*}{ Test } & \multirow{2}{*}{ Date } & \multirow{2}{*}{ Name } & \multirow{2}{*}{$\%$ Water } & \multirow{2}{*}{$\begin{array}{c}\text { Density } \\
\text { (g/ml) }\end{array}$} & \multirow{2}{*}{$\mathbf{p H}$} & \multicolumn{4}{|c|}{ Glass Yield } \\
\hline & & & & & & (kg/kg) & $(g / l)$ & Target & \%Dev. \\
\hline \multirow{2}{*}{1} & $6 / 3 / 10$ & FBL-F-81A & 51.81 & 1.38 & 8.12 & 0.3860 & 513 & 0.399 & -3.26 \\
\hline & $6 / 4 / 10$ & FBL-F-103A & 55.27 & 1.37 & 8.64 & 0.3589 & 492 & 0.359 & -0.03 \\
\hline \multirow{2}{*}{2} & $6 / 8 / 10$ & FBL-F-114A & 55.75 & 1.35 & 8.92 & 0.3527 & 476 & 0.359 & -1.75 \\
\hline & $6 / 10 / 10$ & FBL-F-149A & 52.41 & 1.23 & 9.11 & 0.3902 & 480 & 0.359 & 8.69 \\
\hline \multirow{2}{*}{3} & $6 / 16 / 10$ & GBL-F-21A & 55.39 & 1.28 & 8.96 & 0.3594 & 460 & 0.359 & 0.11 \\
\hline & $6 / 18 / 10$ & GBL-F-54A & 53.27 & 1.26 & 8.94 & 0.3725 & 469 & 0.359 & 3.76 \\
\hline 4 & $7 / 12 / 10$ & GBL-F-71A & 54.67 & 1.32 & 4.5 & 0.3349 & 442 & 0.335 & -0.03 \\
\hline 5 & $7 / 26 / 2010$ & GBL-F-127A & 54.82 & 1.31 & 4.32 & 0.3302 & 433 & 0.335 & -1.43 \\
\hline
\end{tabular}

Table 5.3. XRF Analyzed Compositions of Vitrified Melter Feed Samples Produced from Waste Simulant from Harrell Industries (wt\%).

\begin{tabular}{|c|c|c|c|c|c|c|c|c|c|}
\hline \multirow[b]{2}{*}{ Test } & \multirow[b]{2}{*}{ Target } & \multirow{2}{*}{$\begin{array}{c}\mathbf{1} \\
\text { FBL-F- } \\
81 \mathrm{~A}\end{array}$} & \multirow[b]{2}{*}{$\begin{array}{c}\text { FBL-F- } \\
103 \mathrm{~A}\end{array}$} & \multirow{2}{*}{$\begin{array}{c}\frac{2}{2} \\
\text { FBL-F- } \\
114 A\end{array}$} & \multirow[b]{2}{*}{$\begin{array}{c}\text { FBL-F- } \\
149 \mathrm{~A}\end{array}$} & \multicolumn{2}{|c|}{3} & \multirow[b]{2}{*}{ Average } & \multirow[b]{2}{*}{$\%$ Dev. } \\
\hline & & & & & & $\begin{array}{c}\text { GBL-F- } \\
21 \mathrm{~A}\end{array}$ & $\begin{array}{c}\text { GBL-F- } \\
54 \mathrm{~A}\end{array}$ & & \\
\hline $\mathrm{Al}_{2} \mathrm{O}_{3}$ & 16.35 & 18.63 & 18.27 & 18.33 & 16.56 & 17.82 & 18.63 & 18.04 & 10.34 \\
\hline $\mathrm{B}_{2} \mathrm{O}_{3} *$ & 10.40 & 10.40 & 10.40 & 10.40 & 10.40 & 10.40 & 10.40 & 10.40 & $\mathrm{NC}$ \\
\hline $\mathrm{BaO}$ & 0.09 & 0.07 & 0.09 & 0.09 & 0.07 & 0.07 & 0.08 & 0.08 & $\mathrm{NC}$ \\
\hline $\mathrm{CaO}$ & 1.35 & 1.35 & 1.39 & 1.35 & 1.31 & 1.42 & 1.46 & 1.38 & 2.17 \\
\hline $\mathrm{Ce}_{2} \mathrm{O}_{3}$ & 0.09 & 0.09 & 0.09 & 0.09 & 0.07 & 0.10 & 0.10 & 0.09 & $\mathrm{NC}$ \\
\hline $\mathrm{Cl}$ & 0.01 & 0.05 & 0.05 & 0.05 & 0.05 & 0.05 & 0.05 & 0.05 & $\mathrm{NC}$ \\
\hline $\mathrm{Cr}_{2} \mathrm{O}_{3}$ & 0.15 & 0.23 & 0.23 & 0.22 & 0.21 & 0.23 & 0.24 & 0.23 & $\mathrm{NC}$ \\
\hline $\mathrm{CuO}$ & 0.04 & 0.17 & 0.18 & 0.18 & 0.16 & 0.19 & 0.20 & 0.18 & $\mathrm{NC}$ \\
\hline $\mathrm{Fe}_{2} \mathrm{O}_{3}$ & 8.91 & 7.88 & 8.45 & 8.18 & 7.76 & 8.64 & 8.90 & 8.30 & -6.84 \\
\hline $\mathrm{K}_{2} \mathrm{O}$ & 0.33 & 0.44 & 0.45 & 0.45 & 0.41 & 0.45 & 0.47 & 0.44 & $\mathrm{NC}$ \\
\hline $\mathrm{Li}_{2} \mathrm{O}^{*}$ & 5.20 & 5.20 & 5.20 & 5.20 & 5.20 & 5.20 & 5.20 & 5.20 & $\mathrm{NC}$ \\
\hline $\mathrm{MgO}$ & 0.18 & 0.15 & 0.12 & 0.15 & 0.08 & 0.14 & 0.12 & 0.13 & $\mathrm{NC}$ \\
\hline $\mathrm{MnO}$ & 0.86 & 0.78 & 0.83 & 0.80 & 0.75 & 0.85 & 0.87 & 0.81 & $\mathrm{NC}$ \\
\hline $\mathrm{Na}_{2} \mathrm{O}$ & 13.63 & 13.25 & 13.03 & 13.68 & 11.48 & 12.66 & 12.50 & 12.77 & -6.33 \\
\hline $\mathrm{NiO}$ & 0.15 & 0.13 & 0.14 & 0.14 & 0.13 & 0.14 & 0.15 & 0.14 & $\mathrm{NC}$ \\
\hline $\mathrm{P}_{2} \mathrm{O}_{5}$ & 0.02 & 0.04 & 0.03 & 0.03 & 0.04 & 0.04 & 0.03 & 0.03 & $\mathrm{NC}$ \\
\hline $\mathrm{PbO}$ & 0.03 & 0.03 & 0.03 & 0.03 & 0.03 & 0.03 & 0.03 & 0.03 & $\mathrm{NC}$ \\
\hline $\mathrm{SiO}_{2}$ & 40.34 & 39.45 & 39.26 & 38.92 & 43.62 & 39.73 & 38.66 & 39.94 & -1.00 \\
\hline $\mathrm{SO}_{3}$ & 0.07 & 0.06 & 0.06 & 0.06 & 0.06 & 0.06 & 0.06 & 0.06 & $\mathrm{NC}$ \\
\hline $\mathrm{TiO}_{2}$ & 1.48 & 1.41 & 1.49 & 1.43 & 1.39 & 1.55 & 1.60 & 1.48 & 0.16 \\
\hline $\mathrm{ZnO}$ & 0.04 & 0.04 & 0.05 & 0.04 & 0.04 & 0.05 & 0.05 & 0.04 & $\mathrm{NC}$ \\
\hline $\mathrm{ZrO}_{2}$ & 0.22 & 0.17 & 0.19 & 0.19 & 0.17 & 0.19 & 0.19 & 0.18 & $\mathrm{NC}$ \\
\hline Sum & 100.00 & 100.00 & 100.00 & 100.00 & 100.00 & 100.00 & 100.00 & 100.00 & $\mathrm{NC}$ \\
\hline
\end{tabular}


Table 5.4. XRF Analyzed Compositions for Vitrified Melter Feed Samples Produced from Waste Simulant from NOAH (wt \%).

\begin{tabular}{|c|c|c|c|c|c|}
\hline \multirow{2}{*}{ Test } & \multirow{2}{*}{ Target } & 4 & 5 & \multirow{2}{*}{ Average } & \multirow{2}{*}{$\%$ Dev } \\
\hline & & GBL-F-71A & GBL-F-127A & & \\
\hline $\mathrm{Al}_{2} \mathrm{O}_{3}$ & 16.35 & 16.56 & 17.20 & 16.88 & 3.26 \\
\hline $\mathrm{B}_{2} \mathrm{O}_{3}{ }^{*}$ & 10.40 & 10.40 & 10.40 & 10.40 & $\mathrm{NC}$ \\
\hline $\mathrm{BaO}$ & 0.09 & 0.09 & 0.10 & 0.10 & $\mathrm{NC}$ \\
\hline $\mathrm{CaO}$ & 1.35 & 1.40 & 1.40 & 1.40 & 3.66 \\
\hline $\mathrm{Ce}_{2} \mathrm{O}_{3}$ & 0.09 & 0.11 & 0.10 & 0.11 & $\mathrm{NC}$ \\
\hline $\mathrm{Cl}$ & 0.01 & 0.03 & 0.03 & 0.03 & $\mathrm{NC}$ \\
\hline $\mathrm{Cr}_{2} \mathrm{O}_{3}$ & 0.15 & 0.19 & 0.18 & 0.19 & $\mathrm{NC}$ \\
\hline $\mathrm{CuO}$ & 0.04 & 0.06 & 0.05 & 0.05 & $\mathrm{NC}$ \\
\hline $\mathrm{Fe}_{2} \mathrm{O}_{3}$ & 8.91 & 9.26 & 8.91 & 9.08 & 1.93 \\
\hline $\mathrm{K}_{2} \mathrm{O}$ & 0.33 & 0.36 & 0.36 & 0.36 & $\mathrm{NC}$ \\
\hline $\mathrm{Li}_{2} \mathrm{O}^{*}$ & 5.20 & 5.20 & 5.20 & 5.20 & $\mathrm{NC}$ \\
\hline $\mathrm{MgO}$ & 0.18 & 0.33 & 0.26 & 0.30 & $\mathrm{NC}$ \\
\hline $\mathrm{MnO}$ & 0.86 & 0.89 & 0.87 & 0.88 & $\mathrm{NC}$ \\
\hline $\mathrm{Na}_{2} \mathrm{O}$ & 13.63 & 13.68 & 14.09 & 13.88 & 1.85 \\
\hline $\mathrm{NiO}$ & 0.15 & 0.16 & 0.15 & 0.15 & $\mathrm{NC}$ \\
\hline $\mathrm{P}_{2} \mathrm{O}_{5}$ & 0.02 & 0.04 & 0.04 & 0.04 & $\mathrm{NC}$ \\
\hline $\mathrm{PbO}$ & 0.03 & 0.03 & 0.03 & 0.03 & $\mathrm{NC}$ \\
\hline $\mathrm{SiO}_{2}$ & 40.34 & 39.17 & 38.65 & 38.91 & -3.55 \\
\hline $\mathrm{SO}_{3}$ & 0.07 & 0.14 & 0.15 & 0.14 & $\mathrm{NC}$ \\
\hline $\mathrm{TiO}_{2}$ & 1.48 & 1.60 & 1.60 & 1.60 & 8.42 \\
\hline $\mathrm{ZnO}$ & 0.04 & 0.06 & 0.05 & 0.05 & $\mathrm{NC}$ \\
\hline $\mathrm{ZrO}_{2}$ & 0.22 & 0.26 & 0.20 & 0.23 & $\mathrm{NC}$ \\
\hline Sum & 100.00 & 100.00 & 100.00 & 100.00 & $\mathrm{NC}$ \\
\hline
\end{tabular}

* Target values

$\mathrm{NC}$ - Not Calculated 
The Catholic University of America Vitreous State Laboratory

\section{Table 5.5. Rheological Properties of Melter Feed Produced from Waste Simulated by Different Methods.}

\begin{tabular}{|c|c|c|c|c|c|c|c|c|}
\hline Simulant Type & $\begin{array}{c}\text { \% } \\
\text { Water }\end{array}$ & $\begin{array}{c}\text { Density } \\
\text { (g/ml) }\end{array}$ & $\mathbf{p H}$ & $\begin{array}{c}\text { Glass Yield } \\
\mathbf{( k g} / \mathbf{k g})\end{array}$ & $\begin{array}{c}\text { Yield Stress } \\
\mathbf{( P a )}\end{array}$ & \multicolumn{3}{|c|}{ Viscosity (Poise) } \\
\cline { 7 - 9 } & & & $0.1 / \mathbf{s}$ & @10/s & @100/s \\
\hline $\begin{array}{c}\text { Co-precipitated } \\
\text { Simulant } \\
\text { (Aged melter feed) }\end{array}$ & 55.39 & 1.28 & 8.96 & 0.3594 & 625.7 & 730 & 130 & 15.2 \\
\hline $\begin{array}{c}\text { Co-precipitated } \\
\text { Simulant } \\
\text { (Fresh melter feed) }\end{array}$ & 54.78 & 1.35 & 8.71 & 0.3593 & 246.8 & 93.1 & 116 & 15.4 \\
\hline $\begin{array}{c}\text { Direct Hydroxide } \\
\text { Simulant }\end{array}$ & 54.67 & 1.32 & 4.5 & 0.3349 & 9.8 & 71.2 & 9.74 & 1.60 \\
\hline
\end{tabular}


Table 5.6. List of Glass Discharged, Masses, and Analysis Performed During DM100 Tests with SRS SB19 Sludge.

\begin{tabular}{|c|c|c|c|c|c|}
\hline Test & Date & Name & Analysis & Mass $(\mathrm{kg})$ & Cumulative Mass (kg) \\
\hline \multirow{22}{*}{1} & \multirow{11}{*}{$6 / 3 / 2010$} & FBL-G-81A & XRF,DCP & 38.72 & 38.72 \\
\hline & & FBL-G-82A & - & - & - \\
\hline & & FBL-G-83A & $\mathrm{XRF}$ & 21.22 & 59.94 \\
\hline & & FBL-G-85A & - & - & - \\
\hline & & FBL-G-85B & XRF & 22.21 & 82.15 \\
\hline & & FBL-G-89A & - & - & - \\
\hline & & FBL-G-90A & XRF & 22.58 & 104.73 \\
\hline & & FBL-G-90B & - & - & - \\
\hline & & FBL-G-92A & $\mathrm{XRF}$ & 21.26 & 125.99 \\
\hline & & FBL-G-93A & - & - & - \\
\hline & & FBL-G-94A & XRF & 19.44 & 145.43 \\
\hline & \multirow{10}{*}{$6 / 4 / 2010$} & FBL-G-95A & - & - & - \\
\hline & & FBL-G-100A & $\mathrm{XRF}$ & 30.14 & 175.57 \\
\hline & & FBL-G-101A & - & - & - \\
\hline & & FBL-G-103A & $\mathrm{XRF}$ & 23.30 & 198.87 \\
\hline & & FBL-G-105A & - & - & - \\
\hline & & FBL-G-105B & $\mathrm{XRF}$ & 21.96 & 220.83 \\
\hline & & FBL-G-108A & - & - & - \\
\hline & & FBL-G-109A & $\mathrm{XRF}$ & 24.58 & 245.41 \\
\hline & & FBL-G-109B & - & - & - \\
\hline & & FBL-G-109C & $\mathrm{XRF}$ & 22.64 & 268.05 \\
\hline & $6 / 5 / 2010$ & FBL-G-113A & $\begin{array}{c}\text { XRF,DCP, PCT, SEM, } \\
\mathrm{Fe}^{++}\end{array}$ & 11.48 & 279.53 \\
\hline \multirow{8}{*}{2} & \multirow{5}{*}{ 6/9/2010 } & FBL-G-132A & - & - & - \\
\hline & & FBL-G-132B & $\mathrm{XRF}$ & 19.32 & 298.85 \\
\hline & & FBL-G-133A & - & - & - \\
\hline & & FBL-G-137A & $\mathrm{XRF}$ & 18.78 & 317.63 \\
\hline & & FBL-G-142A & - & - & - \\
\hline & \multirow{3}{*}{$6 / 10 / 2010$} & FBL-G-142B & XRF & 19.58 & 337.21 \\
\hline & & FBL-G-144A & - & - & - \\
\hline & & FBL-G-147A & XRF,DCP, $\mathrm{Fe}^{++}$ & 17.06 & 354.27 \\
\hline \multirow{13}{*}{3} & \multirow{7}{*}{$6 / 16 / 2010$} & GBL-G-23A & - & - & - \\
\hline & & GBL-G-24A & $\mathrm{XRF}, \mathrm{Fe}^{++}$ & 26.98 & 381.25 \\
\hline & & GBL-G-24B & - & - & - \\
\hline & & GBL-G-25A & $\mathrm{XRF}, \mathrm{Fe}^{++}$ & 21.84 & 403.09 \\
\hline & & GBL-G-25B & - & - & - \\
\hline & & GBL-G-27A & $\mathrm{XRF}, \mathrm{Fe}^{++}$ & 20.02 & 423.11 \\
\hline & & GBL-G-27B & - & - & - \\
\hline & \multirow{6}{*}{$6 / 17 / 2010$} & GBL-G-30A & $\mathrm{XRF}, \mathrm{Fe}^{++}$ & 21.76 & 444.87 \\
\hline & & GBL-G-31A & - & - & - \\
\hline & & GBL-G-32A & $\mathrm{XRF}, \mathrm{Fe}^{++}$ & 20.56 & 465.43 \\
\hline & & GBL-G-34A & - & - & - \\
\hline & & GBL-G-39A & $\mathrm{XRF}, \mathrm{Fe}^{++}$ & 23.26 & 488.69 \\
\hline & & GBL-G-39B & - & - & - \\
\hline
\end{tabular}


Table 5.6. List of Glass Discharged, Masses, and Analysis Performed During DM100 Tests with SRS SB19 Sludge (continued).

\begin{tabular}{|c|c|c|c|c|c|}
\hline Test & Date & Name & Analysis & $\begin{array}{c}\text { Mass } \\
(\mathrm{kg})\end{array}$ & $\begin{array}{c}\text { Cumulative Mass } \\
(\mathrm{kg})\end{array}$ \\
\hline \multirow{9}{*}{3} & \multirow{4}{*}{$6 / 17 / 2010$} & GBL-G-41A & $\mathrm{XRF}, \mathrm{Fe}^{++}$ & 26.48 & 515.17 \\
\hline & & GBL-G-42A & - & - & - \\
\hline & & GBL-G-42B & $\mathrm{XRF}, \mathrm{Fe}^{++}$ & 26.44 & 541.61 \\
\hline & & GBL-G-45A & - & - & - \\
\hline & \multirow{5}{*}{$6 / 18 / 2010$} & GBL-G-47A & $\mathrm{XRF}, \mathrm{Fe}^{++}$ & 22.46 & 564.07 \\
\hline & & GBL-G-48A & - & - & - \\
\hline & & GBL-G-48B & $\mathrm{XRF}, \mathrm{Fe}^{++}$ & 25.02 & 589.09 \\
\hline & & GBL-G-53A & - & - & - \\
\hline & & GBL-G-53B & XRF,DCP, PCT, SEM, Fe ${ }^{++}$ & 22.66 & 611.75 \\
\hline \multirow{19}{*}{4} & \multirow{6}{*}{$7 / 12 / 2010$} & GBL-G-73A & - & - & - \\
\hline & & GBL-G-75A & XRF, DCP & 18.62 & 630.37 \\
\hline & & GBL-G-75B & - & - & - \\
\hline & & GBL-G-78A & XRF & 27.90 & 658.27 \\
\hline & & GBL-G-78B & - & - & - \\
\hline & & GBL-G-78C & XRF & 25.18 & 683.45 \\
\hline & \multirow{9}{*}{$7 / 13 / 2010$} & GBL-G-79A & - & - & - \\
\hline & & GBL-G-81A & XRF & 29.04 & 712.49 \\
\hline & & GBL-G-81B & - & - & - \\
\hline & & GBL-G-82A & $\mathrm{XRF}$ & 30.78 & 743.27 \\
\hline & & GBL-G-85A & - & - & - \\
\hline & & GBL-G-87A & XRF & 23.46 & 766.73 \\
\hline & & GBL-G-87B & - & - & - \\
\hline & & GBL-G-87C & XRF & 28.76 & 795.49 \\
\hline & & GBL-G-91A & - & - & - \\
\hline & \multirow{6}{*}{$7 / 14 / 2010$} & GBL-G-92A & $\mathrm{XRF}$ & 29.54 & 825.03 \\
\hline & & GBL-G-92B & - & - & - \\
\hline & & GBL-G-92C & $\mathrm{XRF}, \mathrm{DCP}, \mathrm{Fe}^{++}$ & 29.02 & 854.05 \\
\hline & & GBL-G-93A & - & - & - \\
\hline \multirow{8}{*}{5} & & GBL-G-97A & $\mathrm{XRF}, \mathrm{Fe}^{++}$ & 37.82 & 891.87 \\
\hline & & GBL-G-99A & - & - & - \\
\hline & \multirow{2}{*}{$7 / 15 / 2010$} & GBL-G-107A & $\mathrm{XRF}, \mathrm{Fe}^{++}$ & 35.21 & 927.08 \\
\hline & & GBL-G-109A & - & - & - \\
\hline & \multirow{4}{*}{$7 / 16 / 2010$} & GBL-G-113A & $\mathrm{XRF}, \mathrm{Fe}^{++}$ & 21.88 & 948.96 \\
\hline & & GBL-G-119A & - & - & - \\
\hline & & GBL-G-120A & $\mathrm{XRF}, \mathrm{Fe}^{++}$ & 20.70 & 969.66 \\
\hline & & GBL-G-120B & $\mathrm{XRF}, \mathrm{Fe}^{++}$ & 8.48 & 978.14 \\
\hline
\end{tabular}


Table 5.7. XRF-Analyzed Compositions of Discharged Glass Samples from the DM100 Tests (wt\%).

\begin{tabular}{|c|c|c|c|c|c|c|c|c|c|c|c|c|}
\hline Test & \multicolumn{12}{|c|}{1} \\
\hline Glass (kg) & \multirow[b]{2}{*}{ Target } & 38.72 & 59.94 & 82.15 & 104.73 & 125.99 & 145.43 & 175.57 & 198.87 & 245.41 & 268.05 & 279.53 \\
\hline Constituent & & \begin{tabular}{|c|} 
FBL- \\
G-81A
\end{tabular} & \begin{tabular}{|c|} 
FBL- \\
G-83A
\end{tabular} & \begin{tabular}{|c|} 
FBL- \\
G-85B
\end{tabular} & \begin{tabular}{|c|} 
FBL- \\
G-90A
\end{tabular} & $\begin{array}{l}\text { FBL- } \\
\text { G-92A } \\
\end{array}$ & \begin{tabular}{|c|} 
FBL- \\
G-94A
\end{tabular} & $\begin{array}{c}\text { FBL-G- } \\
100 \mathrm{~A}\end{array}$ & $\begin{array}{c}\text { FBL-G- } \\
103 \mathrm{~A}\end{array}$ & $\begin{array}{c}\text { FBL-G- } \\
109 \mathrm{~A} \\
\end{array}$ & $\begin{array}{c}\text { FBL-G- } \\
109 \mathrm{C} \\
\end{array}$ & $\begin{array}{c}\text { FBL-G- } \\
113 \mathrm{~A}\end{array}$ \\
\hline $\mathrm{Al}_{2} \mathrm{O}_{3}$ & 16.35 & 17.71 & 17.63 & 17.71 & 17.56 & 17.63 & 17.90 & 17.90 & 18.04 & 18.17 & 18.18 & 18.45 \\
\hline $\mathrm{B}_{2} \mathrm{O}_{3}{ }^{*}$ & 10.40 & 11.30 & 11.20 & 11.11 & 11.03 & 10.96 & 10.90 & 10.82 & 10.77 & 10.69 & 10.65 & 10.64 \\
\hline $\mathrm{BaO}$ & 0.09 & 0.04 & 0.03 & 0.05 & 0.05 & 0.04 & 0.05 & 0.05 & 0.07 & 0.07 & 0.07 & 0.06 \\
\hline $\mathrm{Bi}_{2} \mathrm{O}_{3}$ & $\S$ & 0.70 & 0.61 & 0.54 & 0.53 & 0.49 & 0.38 & 0.34 & 0.30 & 0.23 & 0.20 & 0.17 \\
\hline $\mathrm{CaO}$ & 1.35 & 4.82 & 4.38 & 4.00 & 3.91 & 3.72 & 3.26 & 2.99 & 2.82 & 2.48 & 2.38 & 2.20 \\
\hline $\mathrm{Ce}_{2} \mathrm{O}_{3}$ & 0.09 & 0.00 & 0.00 & 0.02 & 0.03 & 0.03 & 0.04 & 0.04 & 0.07 & 0.07 & 0.07 & 0.07 \\
\hline $\mathrm{Cl}$ & 0.01 & 0.01 & 0.01 & 0.02 & 0.02 & 0.03 & 0.03 & 0.03 & 0.03 & 0.03 & 0.03 & 0.03 \\
\hline $\mathrm{Cr}_{2} \mathrm{O}_{3}$ & 0.15 & 0.47 & 0.45 & 0.43 & 0.44 & 0.42 & 0.38 & 0.36 & 0.35 & 0.32 & 0.33 & 0.29 \\
\hline $\mathrm{CuO}$ & 0.04 & 0.01 & 0.03 & 0.04 & 0.07 & 0.07 & 0.09 & 0.11 & 0.12 & 0.14 & 0.14 & 0.13 \\
\hline $\mathrm{Fe}_{2} \mathrm{O}_{3}$ & 8.91 & 7.83 & 7.77 & 7.62 & 8.74 & 8.55 & 8.30 & 8.65 & 8.68 & 8.59 & 8.65 & 7.96 \\
\hline $\mathrm{K}_{2} \mathrm{O}$ & 0.33 & 0.15 & 0.17 & 0.19 & 0.25 & 0.26 & 0.29 & 0.32 & 0.34 & 0.36 & 0.38 & 0.37 \\
\hline $\mathrm{Li}_{2} \mathrm{O}^{*}$ & 5.20 & 5.04 & 5.06 & 5.08 & 5.09 & 5.10 & 5.11 & 5.13 & 5.14 & 5.15 & 5.16 & 5.16 \\
\hline $\mathrm{MgO}$ & 0.18 & 0.13 & 0.15 & 0.15 & 0.13 & 0.12 & 0.11 & 0.10 & 0.11 & 0.17 & 0.12 & 0.13 \\
\hline $\mathrm{MnO}$ & 0.86 & 0.87 & 0.86 & 0.83 & 0.93 & 0.90 & 0.86 & 0.90 & 0.88 & 0.87 & 0.86 & 0.81 \\
\hline $\mathrm{Na}_{2} \mathrm{O}$ & 13.63 & 11.64 & \begin{tabular}{|l|}
12.19 \\
\end{tabular} & 12.35 & 11.60 & 12.09 & 11.95 & 12.64 & 12.47 & 12.78 & 12.89 & 13.55 \\
\hline $\mathrm{NiO}$ & 0.15 & 0.24 & 0.22 & 0.21 & 0.23 & 0.23 & 0.20 & 0.19 & 0.19 & 0.17 & 0.18 & 0.16 \\
\hline $\mathrm{P}_{2} \mathrm{O}_{5}$ & 0.02 & 0.72 & 0.66 & 0.58 & 0.48 & 0.46 & 0.39 & 0.32 & 0.30 & 0.23 & 0.22 & 0.20 \\
\hline $\mathrm{PbO}$ & 0.03 & 0.22 & 0.19 & 0.18 & 0.18 & 0.16 & 0.13 & 0.12 & 0.11 & 0.09 & 0.08 & 0.08 \\
\hline $\mathrm{SiO}_{2}$ & 40.34 & 36.95 & 37.20 & \begin{tabular}{|l|}
37.70 \\
\end{tabular} & 37.31 & 37.31 & 38.17 & 37.44 & 37.63 & 37.74 & 37.75 & 37.98 \\
\hline $\mathrm{SO}_{3}$ & 0.07 & 0.05 & 0.05 & 0.05 & 0.04 & 0.05 & 0.05 & 0.05 & 0.04 & 0.05 & 0.05 & 0.05 \\
\hline $\mathrm{TiO}_{2}$ & 1.48 & 0.51 & 0.61 & 0.67 & 0.86 & 0.89 & 0.99 & 1.10 & 1.15 & 1.24 & 1.26 & 1.21 \\
\hline $\mathrm{ZnO}$ & 0.04 & 0.24 & 0.21 & 0.18 & 0.20 & 0.19 & 0.15 & 0.14 & 0.13 & 0.12 & 0.11 & 0.10 \\
\hline $\mathrm{ZrO}_{2}$ & 0.22 & 0.33 & 0.30 & 0.29 & 0.31 & 0.28 & 0.26 & 0.26 & 0.26 & 0.25 & 0.23 & 0.21 \\
\hline Sum & 100.00 & 100.00 & 100.00 & 100.00 & 100.00 & 100.00 & 100.00 & 100.00 & 100.00 & 100.00 & 100.00 & 100.00 \\
\hline
\end{tabular}

$\S$ - Not a target constituent

* Target values calculated based on simple well stirred tank model 
Table 5.7. XRF-Analyzed Compositions of Discharged Glass Samples from the DM100 Tests (wt \%) (continued).

\begin{tabular}{|c|c|c|c|c|c|c|c|c|c|c|c|c|}
\hline \multirow{3}{*}{\begin{tabular}{|c|} 
Test \\
Glass (kg) \\
Constituent
\end{tabular}} & \multicolumn{5}{|c|}{2} & \\
\hline & \multirow[b]{2}{*}{ Target } & 298.85 & 317.63 & 337.21 & 354.27 & 381.25 & 403.09 & 423.11 & 444.87 & 465.43 & 488.69 & 515.17 \\
\hline & & \begin{tabular}{|c} 
FBL- \\
G- \\
132B
\end{tabular} & $\begin{array}{c}\text { FBL- } \\
\text { G- } \\
137 \mathrm{~A}\end{array}$ & $\begin{array}{c}\text { FBL- } \\
\text { G- } \\
142 B\end{array}$ & \begin{tabular}{|c|} 
FBL- \\
G- \\
$147 \mathrm{~A}$
\end{tabular} & $\begin{array}{l}\text { GBL- } \\
\text { G-24A }\end{array}$ & $\begin{array}{l}\text { GBL- } \\
\text { G-25A }\end{array}$ & $\begin{array}{l}\text { GBL- } \\
\text { G-27A }\end{array}$ & $\begin{array}{l}\text { GBL- } \\
\text { G-30A }\end{array}$ & $\begin{array}{l}\text { GBL- } \\
\text { G-32A }\end{array}$ & GBL- & GBL- \\
\hline $\mathrm{Al}_{2} \mathrm{O}_{3}$ & 6.3 & 18.48 & 18.65 & 18.83 & 18.87 & 8.98 & 8.92 & 8.83 & 8.79 & 8.64 & 8.58 & 8.46 \\
\hline $\mathrm{B}_{2} \mathrm{O}_{3}{ }^{*}$ & 10.40 & 10.61 & 10.59 & 10.57 & 10.56 & 10.53 & 10.52 & 10.51 & 10.49 & 10.48 & 10.47 & 10.46 \\
\hline $\mathrm{BaO}$ & .09 & 0.07 & 0.06 & 0.07 & 0.07 & .07 & 0.08 & 0.07 & .07 & .07 & 0.07 & 0.08 \\
\hline $\mathrm{Bi}_{2} \mathrm{O}_{3}$ & $\S$ & & 0.19 & 0.17 & 0.15 & & & & $\overline{09}$ & 09 & $\overline{07}$ & 06 \\
\hline $\mathrm{CaO}$ & 1.35 & 2.35 & 2.30 & 2.23 & 2.17 & 2.08 & 2.05 & 1.96 & 1.88 & 1.85 & 1.79 & 1.71 \\
\hline$\overline{\mathrm{Ce}_{2} \mathrm{O}_{3}}$ & $\overline{0}$ & 0.07 & 0.07 & 0.07 & 0.08 & & & & 0.08 & 0.08 & .09 & 0.09 \\
\hline $\mathrm{Cl}$ & 0.01 & 0.02 & 0.03 & 0.04 & 0.05 & 0.03 & 0.03 & 03 & .03 & .03 & .03 & 0.03 \\
\hline $\mathrm{Cr}_{2} \mathrm{O}$ & 15 & 0.37 & 0.39 & 0.36 & 0.35 & & & & 0 & 8 & 9 & .27 \\
\hline & 4 & & 0.1 & & 0.1 & & & & & & & 17 \\
\hline $\mathrm{Fe}_{2} \mathrm{O}_{3}$ & 91 & 4 & 9.01 & 8.93 & 9.02 & 49 & 8.75 & 44 & 8.48 & 39 & 55 & .39 \\
\hline & 33 & & 0.40 & 0.41 & 0.42 & 0.42 & 0.43 & 0.43 & 0.43 & 0.43 & 0.44 & 0.43 \\
\hline $\mathrm{Li}_{2} \mathrm{C}$ & 20 & 5. & 5.17 & 5.17 & 5.17 & & 5.18 & 8 & 5.18 & 5.19 & 19 & 5.19 \\
\hline & 18 & & 0 . & 0 & 0.1 & & & 15 & & & & 2 \\
\hline $\mathrm{N}$ & 86 & 0.82 & 0.86 & 0.85 & 0.87 & 81 & 0.83 & 81 & 0.81 & 80 & 0.83 & 0.82 \\
\hline $\mathrm{Na}_{2} \mathrm{O}$ & 3.63 & 12.93 & 12.25 & 12.45 & 12.86 & 13.52 & 13.09 & 13.29 & 13.48 & 13.39 & 12.94 & 13.38 \\
\hline $\mathrm{NiO}$ & 0.15 & 0.19 & 0.20 & 0.19 & 0.19 & 0.16 & 0.17 & 0.16 & 0.17 & 0.15 & 0.15 & 0.15 \\
\hline $\mathrm{P}_{2} \mathrm{O}_{5}$ & 02 & 0.20 & 0.18 & 0.18 & 0.15 & 0.14 & 0.13 & 0.13 & 0.12 & 0.11 & 0.10 & 0.08 \\
\hline $\mathrm{PbO}$ & 0.03 & 0.08 & 0.08 & 0.08 & 0.07 & 0.07 & 0.06 & 0.06 & 0.06 & 0.05 & 0.05 & 0.05 \\
\hline $\mathrm{SiO}_{2}$ & 40.34 & 37.70 & 37.55 & 37.37 & 36.90 & 36.93 & 37.13 & 37.52 & 37.47 & 37.92 & 38.24 & 38.29 \\
\hline & 0.07 & 0.05 & 0.05 & 0.06 & 0.07 & 0.05 & 0.05 & 0.05 & 0.05 & 0.05 & 0.04 & 0.04 \\
\hline $\mathrm{TiO}_{2}$ & 1.48 & 1.25 & 1.33 & 1.36 & 1.38 & 1.39 & 1.43 & 1.41 & 1.41 & 1.41 & 1.46 & 1.44 \\
\hline $\mathrm{ZnO}$ & 0.04 & 0.12 & 0.12 & 0.12 & 0.11 & 0.10 & 0.10 & 0.10 & 0.08 & 0.08 & 0.08 & 0.08 \\
\hline & 0.22 & 0.23 & 0.24 & 0.23 & 0.23 & 0.22 & 0.23 & 0.22 & 0.21 & 0.21 & 0.22 & 0.21 \\
\hline Sum & 00.00 & 100.00 & 100.00 & 100.00 & 100.00 & 100.00 & 100.00 & 100.00 & 100.00 & 100.00 & 100.00 & 100.00 \\
\hline
\end{tabular}

$\S$ - Not a target constituent

* Target values calculated based on simple well stirred tank model 
Table 5.7. XRF-Analyzed Compositions of Discharged Glass Samples from the DM100 Tests (wt\%) (continued).

\begin{tabular}{|c|c|c|c|c|c|c|c|c|c|c|c|}
\hline Test & \multicolumn{6}{|c|}{3} & \multicolumn{5}{|c|}{4} \\
\hline Glass (kg) & \multirow[b]{2}{*}{ irget } & \multirow{2}{*}{\begin{tabular}{|c}
541.61 \\
GBL- \\
G-42B \\
\end{tabular}} & \multirow{2}{*}{\begin{tabular}{|c|}
564.07 \\
GBL- \\
G-47A \\
\end{tabular}} & \multirow{2}{*}{$\begin{array}{c}589.09 \\
\text { GBL- } \\
\text { G-48B } \\
\end{array}$} & \multicolumn{2}{|c|}{611.75} & \multirow{2}{*}{\begin{tabular}{|c}
630.37 \\
GBL- \\
G-75A \\
\end{tabular}} & \multirow{2}{*}{\begin{tabular}{|c|}
658.27 \\
GBL- \\
G-78A \\
\end{tabular}} & \multirow{2}{*}{\begin{tabular}{|c|}
683.45 \\
GBL- \\
G-78C \\
\end{tabular}} & \multirow{2}{*}{$\begin{array}{r}712.49 \\
\text { GBL- } \\
\text { G-81A } \\
\end{array}$} & \multirow{2}{*}{\begin{tabular}{|c|}
743.27 \\
GBL-G \\
$82 \mathrm{~A}$ \\
\end{tabular}} \\
\hline Constituent & & & & & $\begin{array}{l}\text { GBL- } \\
\text { G-53B }\end{array}$ & $\%$ Dev. & & & & & \\
\hline $\mathrm{Al}_{2} \mathrm{O}_{3}$ & 16.35 & 18.67 & 18.47 & 18.49 & 18.29 & 11.90 & 18.18 & 17.89 & 17.65 & 17.28 & 17.15 \\
\hline $\mathrm{B}_{2} \mathrm{O}_{3} *$ & 10.40 & 10.46 & 10.45 & 10.44 & 10.44 & $\mathrm{NC}$ & 10.43 & 10.43 & 10.43 & 10.42 & 10.42 \\
\hline $\mathrm{BaO}$ & 0.09 & 0.06 & 0.06 & 0.06 & 0.06 & $\mathrm{NC}$ & 0.08 & 0.07 & 0.08 & 0.08 & 0.08 \\
\hline $\mathrm{Bi}_{2} \mathrm{O}_{3}$ & $\S$ & 05 & 0.05 & 0.04 & .04 & $\mathrm{NC}$ & 0.04 & 0.04 & 0.03 & 0.03 & 0.02 \\
\hline $\mathrm{CaO}$ & 1.35 & 1.63 & 1.65 & 1.56 & 1.60 & 18.42 & 1.58 & 1.54 & 1.50 & 1.49 & 1.41 \\
\hline$\overline{\mathrm{Ce}_{2} \mathrm{O}_{3}}$ & 0.09 & 0.09 & 0.09 & 0.10 & 0.09 & $\mathrm{NC}$ & 0.10 & 0.08 & 0.09 & 0.08 & 0.10 \\
\hline $\mathrm{Cl}$ & 0.01 & 03 & 0.03 & 3 & 3 & $\mathrm{NC}$ & 0.01 & 1 & 01 & 0.01 & 0.02 \\
\hline $\mathrm{Cr}_{2} \mathrm{O}_{3}$ & & 6 & 0.27 & 27 & 28 & $\mathrm{NC}$ & 5 & 0.25 & .23 & 0.23 & 0.22 \\
\hline $\mathrm{CuO}$ & 0.04 & 6 & 0.18 & 17 & 0.18 & $\mathrm{NC}$ & 15 & 0.14 & 0.12 & 0.11 & 0.10 \\
\hline $\mathrm{Fe}_{2} \mathrm{O}_{3}$ & 8.91 & 8.14 & 8.51 & 8.15 & 8.65 & -2.93 & 8.33 & 8.42 & 8.21 & 8.34 & 8.19 \\
\hline $\mathrm{K}_{2} \mathrm{O}$ & 0.33 & 0.43 & 0.45 & 0.44 & 0.45 & $\mathrm{NC}$ & 0.42 & 0.41 & 0.40 & 0.39 & 0.38 \\
\hline $\mathrm{Li}_{2} \mathrm{O}^{*}$ & 5.20 & 5.19 & 5.19 & 5.19 & 5.19 & $\mathrm{NC}$ & 5.19 & 5.19 & 5.20 & 5.20 & 5.20 \\
\hline $\mathrm{MgO}$ & 0.18 & 0.15 & 0.13 & 0.12 & 0.15 & $\mathrm{NC}$ & 0.18 & 0.14 & 0.17 & 0.24 & 0.17 \\
\hline $\mathrm{MnO}$ & 0.86 & 0.80 & 0.83 & 0.79 & 0.84 & $\mathrm{NC}$ & 0.78 & 0.79 & 0.77 & 0.79 & 0.78 \\
\hline $\mathrm{Na}_{2} \mathrm{O}$ & 13.63 & 13.39 & 12.83 & 13.66 & 13.27 & -2.63 & 13.27 & 13.46 & 12.91 & 12.88 & 12.56 \\
\hline $\mathrm{NiO}$ & 0.15 & 0.14 & 0.16 & 0.15 & 0.15 & $\mathrm{NC}$ & 0.14 & 0.14 & 0.14 & 0.14 & 0.13 \\
\hline $\mathrm{P}_{2} \mathrm{O}_{5}$ & 0.02 & 0.08 & 0.08 & 0.07 & 0.06 & $\mathrm{NC}$ & 0.06 & 0.06 & 0.06 & 0.05 & 0.05 \\
\hline $\mathrm{PbO}$ & 0.03 & 0.04 & 0.04 & 0.04 & 0.04 & $\mathrm{NC}$ & 0.04 & 0.04 & 0.04 & 0.04 & 0.03 \\
\hline $\mathrm{SiO}_{2}$ & 40.34 & 38.49 & 38.76 & 38.51 & 38.37 & -4.90 & 39.00 & 39.14 & 40.21 & 40.42 & 41.23 \\
\hline $\mathrm{SO}_{3}$ & 0.07 & 0.04 & 0.04 & 0.04 & 0.04 & $\mathrm{NC}$ & 0.04 & 0.06 & 0.06 & 0.07 & 0.08 \\
\hline $\mathrm{TiO}_{2}$ & 1.48 & 1.43 & 1.48 & 1.45 & 1.51 & 2.28 & 1.43 & 1.43 & 1.42 & 1.43 & 1.41 \\
\hline $\mathrm{ZnO}$ & 0.04 & 0.07 & 0.07 & 0.06 & 0.07 & $\mathrm{NC}$ & 0.08 & 0.08 & 0.07 & 0.07 & 0.06 \\
\hline $\mathrm{ZrO}_{2}$ & 0.22 & 0.20 & 0.19 & 0.19 & 0.20 & $\mathrm{NC}$ & 0.21 & 0.20 & 0.21 & 0.21 & 0.21 \\
\hline Sum & 100.00 & 100.00 & 100.00 & 100.00 & 100.00 & $\mathrm{NC}$ & 100.00 & 100.00 & 100.00 & 100.00 & 100.00 \\
\hline
\end{tabular}

$\S$ - Not a target constituent

* Target values calculated based on simple well stirred tank model

$\mathrm{NC}-$ Not calculated 
Table 5.7. XRF-Analyzed Compositions of Discharged Glass Samples from the DM100 Tests (wt\%) (continued).

\begin{tabular}{|c|c|c|c|c|c|c|c|c|c|c|c|}
\hline Test & & & 4 & & & & & 5 & & & \\
\hline Glass (kg) & & 766.73 & \begin{tabular}{|l|}
795.49 \\
\end{tabular} & \begin{tabular}{|l|}
825.03 \\
\end{tabular} & 854.05 & 891.87 & \begin{tabular}{|l|}
927.08 \\
\end{tabular} & \begin{tabular}{|l|}
948.96 \\
\end{tabular} & 969.66 & 978 & .14 \\
\hline Constituent & Target & \begin{tabular}{|r|} 
GBL- \\
G-87A \\
\end{tabular} & \begin{tabular}{|c|} 
GBL- \\
G-87C \\
\end{tabular} & \begin{tabular}{|c|} 
GBL- \\
G-92A \\
\end{tabular} & $\begin{array}{l}\text { GBL- } \\
\text { G-92C }\end{array}$ & $\begin{array}{l}\text { GBL- } \\
\text { G-97A }\end{array}$ & $\begin{array}{c}\text { GBL- } \\
\text { G-107A }\end{array}$ & \begin{tabular}{|c|} 
GBL- \\
G-113A \\
\end{tabular} & $\begin{array}{c}\text { GBL- } \\
\text { G-120A }\end{array}$ & $\begin{array}{c}\text { GBL- } \\
\text { G-120B }\end{array}$ & $\%$ Dev. \\
\hline $\mathrm{Al}_{2} \mathrm{O}_{3}$ & 16.35 & 16.78 & 16.23 & 15.87 & 15.81 & 15.59 & 14.90 & 15.22 & 15.88 & 16.21 & -0.81 \\
\hline $\mathrm{B}_{2} \mathrm{O}_{3} *$ & 10.40 & 10.42 & 10.41 & 10.41 & 10.41 & 10.41 & 10.41 & 10.41 & 10.41 & 10.40 & $\mathrm{NC}$ \\
\hline $\mathrm{BaO}$ & 0.09 & 0.08 & 0.08 & 0.07 & 0.09 & 0.07 & 0.09 & 0.08 & 0.09 & 0.09 & $\mathrm{NC}$ \\
\hline $\mathrm{Bi}_{2} \mathrm{O}_{3}$ & $\S$ & 0.02 & 0.02 & 0.01 & 0.01 & 0.01 & 0.01 & 0.01 & 0.01 & 0.01 & $\mathrm{NC}$ \\
\hline $\mathrm{CaO}$ & 1.35 & 1.40 & 1.41 & 1.37 & 1.31 & 1.34 & 1.34 & 1.31 & 1.32 & 1.36 & 0.67 \\
\hline $\mathrm{Ce}_{2} \mathrm{O}_{3}$ & 0.09 & 0.08 & 0.09 & 0.09 & 0.09 & 0.10 & 0.09 & 0.09 & 0.08 & 0.09 & $\mathrm{NC}$ \\
\hline $\mathrm{Cl}$ & 0.01 & 0.02 & 0.02 & .02 & .02 & 01 & 02 & 0.02 & 02 & 0.02 & $\mathrm{NC}$ \\
\hline $\mathrm{Cr}_{2} \mathrm{O}_{3}$ & 0.15 & 0.21 & 0.22 & 0.21 & 0.21 & 0.26 & 0.25 & 0.25 & .23 & 0.24 & $\mathrm{NC}$ \\
\hline $\mathrm{CuO}$ & 0.04 & 0.09 & 0.09 & 0.08 & 0.07 & 0.07 & .07 & 0.06 & .06 & 0.06 & $\mathrm{NC}$ \\
\hline $\mathrm{Fe}_{2} \mathrm{O}_{3}$ & 8.91 & 8.24 & 8.68 & 8.43 & 8.17 & 8.55 & 8.72 & 8.52 & 8.26 & 8.80 & -1.24 \\
\hline $\mathrm{K}_{2} \mathrm{O}$ & 0.33 & 0.37 & 0.38 & 0.36 & 0.35 & 0.36 & 0.35 & 0.33 & 0.34 & 0.35 & $\mathrm{NC}$ \\
\hline $\mathrm{Li}_{2} \mathrm{O}^{*}$ & 5.20 & 5.20 & 5.20 & 5.20 & 5.20 & 5.20 & 5.20 & 5.20 & 5.20 & 5.20 & $\mathrm{NC}$ \\
\hline $\mathrm{MgO}$ & 0.18 & 0.24 & 0.20 & 0.24 & 0.20 & 0.21 & 0.27 & 0.22 & 27 & 0.26 & $\mathrm{NC}$ \\
\hline $\mathrm{MnO}$ & 0.86 & 0.79 & 0.82 & 0.80 & 0.77 & 0.82 & 0.82 & 0.81 & 0.78 & 0.84 & -2.37 \\
\hline $\mathrm{Na}_{2} \mathrm{O}$ & 13.63 & 12.42 & 12.36 & 12.46 & 12.34 & 12.11 & 11.57 & 11.44 & 12.97 & 12.46 & -8.56 \\
\hline $\mathrm{NiO}$ & 0.15 & 0.14 & 0.16 & 0.15 & 0.14 & 0.17 & 0.17 & 0.16 & 0.15 & 0.16 & $\mathrm{NC}$ \\
\hline $\mathrm{P}_{2} \mathrm{O}_{5}$ & 0.02 & 0.05 & 0.05 & 0.05 & 0.04 & 0.04 & 0.04 & 0.05 & 0.04 & 0.04 & $\mathrm{NC}$ \\
\hline $\mathrm{PbO}$ & 0.03 & 0.03 & 0.03 & 0.03 & 0.03 & 0.03 & 0.03 & 0.03 & 0.03 & 0.03 & $\mathrm{NC}$ \\
\hline $\mathrm{SiO}_{2}$ & 40.34 & 41.64 & 41.72 & 42.36 & 42.99 & 42.87 & 43.81 & 44.00 & \begin{tabular}{|l|l|}
42.13 \\
\end{tabular} & 41.49 & 2.85 \\
\hline $\mathrm{SO}_{3}$ & 0.07 & 0.09 & 0.09 & 0.09 & 0.09 & 0.10 & 0.11 & 0.11 & 0.11 & 0.12 & $\mathrm{NC}$ \\
\hline $\mathrm{TiO}_{2}$ & 1.48 & 1.42 & 1.46 & 1.43 & 1.40 & 1.43 & 1.45 & 1.42 & 1.40 & 1.48 & 0.26 \\
\hline $\mathrm{ZnO}$ & 0.04 & 0.06 & 0.06 & 0.06 & 0.06 & 0.06 & 0.07 & 0.06 & 0.06 & 0.06 & $\mathrm{NC}$ \\
\hline $\mathrm{ZrO}_{2}$ & 0.22 & 0.21 & 0.22 & 0.21 & 0.20 & 0.20 & 0.21 & 0.21 & 0.19 & 0.21 & $\mathrm{NC}$ \\
\hline Sum & 100.00 & 100.00 & $\mid 100.00$ & 100.00 & 100.00 & 100.00 & 100.00 & 100.00 & 100.00 & 100.00 & $\mathrm{NC}$ \\
\hline
\end{tabular}

$\S$ - Not a target constituent

* Target values calculated based on simple well stirred tank model

$\mathrm{NC}-$ Not calculated 
Table 5.8. XRF and DCP Analyzed Compositions of Glass Samples Collected During DM100 Tests (wt\%).

\begin{tabular}{|c|c|c|c|c|c|c|c|}
\hline \multirow{3}{*}{$\begin{array}{c}\text { Test } \\
\text { Sample } \\
\text { Oxide }\end{array}$} & \multicolumn{5}{|c|}{1} & \multirow{2}{*}{\multicolumn{2}{|c|}{$\begin{array}{c}\mathbf{2} \\
\text { FBL-G-147A }\end{array}$}} \\
\hline & \multirow{2}{*}{ Target } & \multicolumn{2}{|c|}{ FBL-G-81A } & \multicolumn{2}{|c|}{ FBL-G-113A } & & \\
\hline & & XRF & DCP & XRF & $\mathrm{DCP}$ & XRF & DCP \\
\hline $\mathrm{Al}_{2} \mathrm{O}_{3}$ & 16.35 & 17.71 & 16.66 & 18.45 & 17.73 & 18.87 & 17.67 \\
\hline $\mathrm{B}_{2} \mathrm{O}_{3}{ }^{*}$ & 10.40 & 11.30 & 11.57 & 10.64 & 10.61 & 10.56 & 10.14 \\
\hline $\mathrm{BaO}$ & 0.09 & 0.04 & 0.04 & 0.06 & 0.06 & 0.07 & 0.07 \\
\hline $\mathrm{Bi}_{2} \mathrm{O}_{3}$ & $\S$ & 0.70 & 0.81 & 0.17 & 0.25 & 0.15 & 0.21 \\
\hline $\mathrm{CaO}$ & 1.35 & 4.82 & 4.49 & 2.20 & 2.04 & 2.17 & 1.92 \\
\hline $\mathrm{Ce}_{2} \mathrm{O}_{3}$ & 0.09 & 0.00 & NA & 0.07 & NA & 0.08 & NA \\
\hline $\mathrm{Cl}$ & 0.01 & 0.01 & NA & 0.03 & NA & 0.05 & NA \\
\hline $\mathrm{Cr}_{2} \mathrm{O}_{3}$ & 0.15 & 0.47 & 0.35 & 0.29 & 0.21 & 0.35 & 0.21 \\
\hline $\mathrm{CuO}$ & 0.04 & 0.01 & 0.01 & 0.13 & 0.11 & 0.16 & 0.12 \\
\hline $\mathrm{Fe}_{2} \mathrm{O}_{3}$ & 8.91 & 7.83 & 8.04 & 7.96 & 8.24 & 9.02 & 8.29 \\
\hline $\mathrm{K}_{2} \mathrm{O}$ & 0.33 & 0.15 & 0.17 & 0.37 & 0.42 & 0.42 & 0.44 \\
\hline $\mathrm{Li}_{2} \mathrm{O}^{*}$ & 5.20 & 5.04 & 4.89 & 5.16 & 4.86 & 5.17 & 4.75 \\
\hline $\mathrm{MgO}$ & 0.18 & 0.13 & 0.19 & 0.13 & 0.20 & 0.13 & 0.21 \\
\hline $\mathrm{MnO}$ & 0.86 & 0.87 & 0.96 & 0.81 & 0.89 & 0.87 & 0.87 \\
\hline $\mathrm{Na}_{2} \mathrm{O}$ & 13.63 & 11.64 & 10.05 & 13.55 & 11.68 & 12.86 & 11.68 \\
\hline $\mathrm{NiO}$ & 0.15 & 0.24 & 0.26 & 0.16 & 0.18 & 0.19 & 0.18 \\
\hline $\mathrm{P}_{2} \mathrm{O}_{5}$ & 0.02 & 0.72 & 0.58 & 0.20 & 0.24 & 0.15 & 0.14 \\
\hline $\mathrm{PbO}$ & 0.03 & 0.22 & 0.29 & 0.08 & 0.11 & 0.07 & 0.10 \\
\hline $\mathrm{SiO}_{2}$ & 40.34 & 36.95 & 36.09 & 37.98 & 37.93 & 36.90 & 36.52 \\
\hline $\mathrm{SO}_{3}$ & 0.07 & 0.05 & $\mathrm{NA}$ & 0.05 & NA & 0.07 & $\mathrm{NA}$ \\
\hline $\mathrm{TiO}_{2}$ & 1.48 & 0.51 & 0.55 & 1.21 & 1.31 & 1.38 & 1.36 \\
\hline $\mathrm{ZnO}$ & 0.04 & 0.24 & 0.25 & 0.10 & 0.1 & 0.11 & 0.1 \\
\hline $\mathrm{ZrO}_{2}$ & 0.22 & 0.33 & 0.40 & 0.21 & 0.26 & 0.23 & 0.24 \\
\hline Sum & 100.00 & 100.00 & 96.65 & 100.00 & 97.43 & 100.00 & 95.22 \\
\hline
\end{tabular}

* Target values calculated based on simple well stirred tank model for XRF; analyzed value for DCP $\S$ - Not a target constituent

NA - Not analyzed 
Table 5.8. XRF and DCP Analyzed Compositions for Glass Samples Collected During DM100 Tests (wt \%) (continued).

\begin{tabular}{|c|c|c|c|c|c|c|c|}
\hline \multirow{3}{*}{$\begin{array}{c}\text { Test } \\
\text { Sample } \\
\text { Oxide }\end{array}$} & \multicolumn{3}{|c|}{3} & \multicolumn{4}{|c|}{4} \\
\hline & \multirow{2}{*}{ Target } & \multicolumn{2}{|c|}{ GBL-G-53B } & \multicolumn{2}{|c|}{ GBL-G-75A } & \multicolumn{2}{|c|}{ GBL-G-92C } \\
\hline & & XRF & DCP & XRF & DCP & XRF & DCP \\
\hline $\mathrm{Al}_{2} \mathrm{O}_{3}$ & 16.35 & 18.29 & 16.79 & 18.18 & 17.13 & 15.81 & 14.58 \\
\hline $\mathrm{B}_{2} \mathrm{O}_{3} *$ & 10.40 & 10.44 & 10.17 & 10.43 & 10.47 & 10.41 & 10.37 \\
\hline $\mathrm{BaO}$ & 0.09 & 0.06 & 0.07 & 0.08 & 0.07 & 0.09 & 0.08 \\
\hline $\mathrm{Bi}_{2} \mathrm{O}_{3}$ & $\S$ & 0.04 & 0.11 & 0.04 & 0.10 & 0.01 & 0.05 \\
\hline $\mathrm{CaO}$ & 1.35 & 1.60 & 1.69 & 1.58 & 1.45 & 1.31 & 1.40 \\
\hline $\mathrm{Ce}_{2} \mathrm{O}_{3}$ & 0.09 & 0.09 & NA & 0.10 & NA & 0.09 & NA \\
\hline $\mathrm{Cl}$ & 0.01 & 0.03 & NA & 0.01 & NA & 0.02 & NA \\
\hline $\mathrm{Cr}_{2} \mathrm{O}_{3}$ & 0.15 & 0.28 & 0.12 & 0.25 & 0.21 & 0.21 & 0.15 \\
\hline $\mathrm{CuO}$ & 0.04 & 0.18 & 0.13 & 0.15 & 0.12 & 0.07 & 0.06 \\
\hline $\mathrm{Fe}_{2} \mathrm{O}_{3}$ & 8.91 & 8.65 & 8.06 & 8.33 & 8.10 & 8.17 & 7.87 \\
\hline $\mathrm{K}_{2} \mathrm{O}$ & 0.33 & 0.45 & 0.48 & 0.42 & 0.47 & 0.35 & 0.39 \\
\hline $\mathrm{Li}_{2} \mathrm{O}^{*}$ & 5.20 & 5.19 & 4.97 & 5.19 & 4.92 & 5.20 & 5.07 \\
\hline $\mathrm{MgO}$ & 0.18 & 0.15 & 0.20 & 0.18 & 0.22 & 0.20 & 0.30 \\
\hline $\mathrm{MnO}$ & 0.86 & 0.84 & 0.86 & 0.78 & 0.82 & 0.77 & 0.84 \\
\hline $\mathrm{Na}_{2} \mathrm{O}$ & 13.63 & 13.27 & 11.53 & 13.27 & 11.57 & 12.34 & 10.79 \\
\hline $\mathrm{NiO}$ & 0.15 & 0.15 & 0.15 & 0.14 & 0.15 & 0.14 & 0.15 \\
\hline $\mathrm{P}_{2} \mathrm{O}_{5}$ & 0.02 & 0.06 & 0.13 & 0.06 & 0.23 & 0.04 & 0.11 \\
\hline $\mathrm{PbO}$ & 0.03 & 0.04 & 0.06 & 0.04 & 0.07 & 0.03 & 0.05 \\
\hline $\mathrm{SiO}_{2}$ & 40.34 & 38.37 & 37.80 & 39.00 & 37.94 & 42.99 & 41.44 \\
\hline $\mathrm{SO}_{3}$ & 0.07 & 0.04 & NA & 0.04 & NA & 0.09 & NA \\
\hline $\mathrm{TiO}_{2}$ & 1.48 & 1.51 & 1.50 & 1.43 & 1.47 & 1.40 & 1.43 \\
\hline $\mathrm{ZnO}$ & 0.04 & 0.07 & 0.06 & 0.08 & 0.08 & 0.06 & 0.05 \\
\hline $\mathrm{ZrO}_{2}$ & 0.22 & 0.20 & 0.22 & 0.21 & 0.23 & 0.20 & 0.22 \\
\hline Sum & 100.00 & 100.00 & 95.10 & 100.00 & 95.82 & 100.00 & 95.40 \\
\hline
\end{tabular}

* Target values calculated based on simple well stirred tank model for XRF; analyzed values for DCP $\S$ - Not a target constituent

NA - Not analyzed 
Table 5.9. Divalent Iron Measured by Mossbauer Spectroscopy on Glasses Discharged During DM100 Tests.

\begin{tabular}{|c|c|c|c|}
\hline \multirow{2}{*}{ Test } & Sample & $\begin{array}{c}\text { Cumulative Glass } \\
\text { Discharge (kg) }\end{array}$ & $\begin{array}{c}\mathbf{\%} \mathbf{F e}^{++} / \\
\text {Total Iron }\end{array}$ \\
\hline 1 & FBL-G-113A & 280 & $<1.0$ \\
\hline 2 & FBL-G-147A & 354 & $<1.0$ \\
\hline \multirow{4}{*}{} & GBL-G-24A & 381 & $<1.0$ \\
\cline { 2 - 4 } & GBL-G-25A & 403 & $<1.0$ \\
\cline { 2 - 4 } & GBL-G-27A & 423 & $<1.0$ \\
\cline { 2 - 4 } & GBL-G-30A & 445 & 4.9 \\
\cline { 2 - 4 } & GBL-G-32A & 465 & 5.9 \\
\cline { 2 - 4 } & GBL-G-39A & 489 & 11 \\
\cline { 2 - 4 } & GBL-G-41A & 515 & 13 \\
\cline { 2 - 4 } & GBL-G-42B & 542 & 18 \\
\cline { 2 - 4 } & GBL-G-47A & 564 & 12 \\
\cline { 2 - 4 } & GBL-G-48B & 589 & 13 \\
\cline { 2 - 4 } & GBL-G-53B & 612 & 15 \\
\hline 4 & GBL-G-92C & 854 & 2.2 \\
\hline \multirow{4}{*}{5} & GBL-G-97A & 892 & 2.9 \\
\cline { 2 - 4 } & GBL-G-107A & 927 & 4.9 \\
\cline { 2 - 4 } & GBL-G-113A & 949 & \\
\cline { 2 - 4 } & GBL-G-120A & 970 & \\
\hline
\end{tabular}


Table 5.10. PCT Results (ASTM C1285, 7-days at $90^{\circ} \mathrm{C}$, Stainless Steel Vessel; S/V=2000 $\mathrm{m}^{-1}$ ) for Melter Glasses.

\begin{tabular}{|c|c|c|c|c|}
\hline Test & & 1 & 3 & \multirow{2}{*}{ DWPF-EA } \\
\hline \multicolumn{2}{|l|}{ Glass Samples } & FBL-G-113A & GBL-G-53B & \\
\hline \multirow{4}{*}{ 7-Day PCT Concentration, (mg/L) } & $\mathrm{B}$ & 12.26 & 11.73 & - \\
\hline & $\mathrm{Li}$ & 13.31 & 13.17 & - \\
\hline & $\mathrm{Na}$ & 42.40 & 47.19 & - \\
\hline & $\mathrm{Si}$ & 51.98 & 62.09 & - \\
\hline \multirow{5}{*}{ 7-Day PCT Normalized Concentrations, (g/L) } & $\mathrm{B}$ & 0.37 & 0.36 & 16.70 \\
\hline & $\mathrm{Li}$ & 0.56 & 0.55 & 9.57 \\
\hline & $\mathrm{Na}$ & 0.42 & 0.48 & 13.35 \\
\hline & $\mathrm{Si}$ & 0.29 & 0.35 & 3.92 \\
\hline & $\mathrm{pH}$ & 10.68 & 10.66 & - \\
\hline \multirow{4}{*}{ 7-Day PCT Normalized Mass Loss, (g/m²) } & $\mathrm{B}$ & 0.19 & 0.18 & - \\
\hline & $\mathrm{Li}$ & 0.28 & 0.27 & - \\
\hline & $\mathrm{Na}$ & 0.21 & 0.24 & - \\
\hline & $\mathrm{Si}$ & 0.15 & 0.17 & - \\
\hline \multirow{4}{*}{ 7-Day PCT Normalized Loss Rate, $\left(\mathrm{g} / \mathrm{d} / \mathrm{m}^{2}\right)$} & $\mathrm{B}$ & 0.03 & 0.03 & - \\
\hline & $\mathrm{Li}$ & 0.04 & 0.04 & - \\
\hline & $\mathrm{Na}$ & 0.03 & 0.03 & - \\
\hline & $\mathrm{Si}$ & 0.02 & 0.02 & - \\
\hline
\end{tabular}

- empty data field 
Table 6.1. DM100 Melter Off-Gas Emission Results from Tests with SRS SB19 Simulant Prepared by Harrell Industries.

\begin{tabular}{|c|c|c|c|c|c|c|c|c|c|}
\hline & \multicolumn{4}{|c|}{ Test $1,11.8 \mathrm{lpm}$ air bubbling } & \multicolumn{4}{|c|}{ Test 2, $0 \mathrm{lpm}$ bubbling } \\
\hline & & \multicolumn{4}{|c|}{$\begin{array}{c}\text { 6/4/10 13:07-14:21 } \\
10.9 \% \text { Moisture; } 95.8 \% \text { Isokinetic }\end{array}$} & \multicolumn{4}{|c|}{$\begin{array}{c}6 / 10 / 1017: 48-18: 48 \\
4.7 \% \text { Moisture; } 105.4 \% \text { Isokinetic }\end{array}$} \\
\hline & & $\begin{array}{c}\text { Feed }^{\#} \\
(\mathrm{mg} / \mathrm{min})\end{array}$ & $\begin{array}{l}\text { Output } \\
(\mathrm{mg} / \mathrm{min})\end{array}$ & $\begin{array}{c}\% \\
\text { Emitted }\end{array}$ & DF & $\begin{array}{c}\text { Feed }^{\#} \\
(\mathrm{mg} / \mathrm{min})\end{array}$ & $\begin{array}{c}\text { Output } \\
(\mathrm{mg} / \mathrm{min})\end{array}$ & $\begin{array}{c}\% \\
\text { Emitted }\end{array}$ & DF \\
\hline \multirow{23}{*}{ 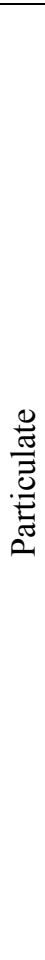 } & Total $^{\$}$ & 105963 & 86.1 & 0.08 & 1231 & 42059 & 17.7 & 0.04 & 2371 \\
\hline & $\mathrm{Al}$ & 7355 & 3.10 & 0.04 & 2370 & 2951 & 0.32 & 0.01 & 9263 \\
\hline & $\mathrm{B}$ & 2745 & 2.04 & 0.07 & 1343 & 1101 & 0.21 & 0.02 & 5195 \\
\hline & $\mathrm{Ba}$ & 67.0 & $<0.10$ & $<0.15$ & $>670$ & 26.9 & $<0.10$ & $<0.37$ & $>269$ \\
\hline & $\mathrm{Ca}$ & 821 & 1.14 & 0.14 & 720 & 330 & 0.52 & 0.16 & 635.2 \\
\hline & $\mathrm{Cl}^{*}$ & 10.2 & NA & $\mathrm{NC}$ & $\mathrm{NC}$ & 4.1 & NA & $\mathrm{NC}$ & $\mathrm{NC}$ \\
\hline & $\mathrm{Cr}$ & 90.2 & 0.36 & 0.40 & 250 & 36.2 & $<0.10$ & $<0.28$ & $>362$ \\
\hline & $\mathrm{Cu}$ & 28.5 & $<0.10$ & $<0.35$ & $>285$ & 11.4 & $<0.10$ & $<0.87$ & $>114$ \\
\hline & $\mathrm{F}^{*}$ & 2.6 & NA & $\mathrm{NC}$ & $\mathrm{NC}$ & 1.0 & NA & $\mathrm{NC}$ & $\mathrm{NC}$ \\
\hline & $\mathrm{Fe}$ & 5300 & 1.70 & 0.03 & 3110 & 2126 & $<0.10$ & $<0.00$ & $>21264$ \\
\hline & $\mathrm{K}$ & 231 & 1.11 & 0.48 & 207 & 92.6 & $<0.10$ & $<0.11$ & $>926$ \\
\hline & $\mathrm{Li}$ & 2054 & 1.35 & 0.07 & 1523 & 824 & $<0.10$ & $<0.01$ & $>8242$ \\
\hline & $\mathrm{Mg}$ & 91.8 & 0.14 & 0.16 & 638 & 36.8 & 0.18 & 0.48 & 207 \\
\hline & $\mathrm{Mn}$ & 565 & 0.10 & 0.02 & 5514 & 227 & $<0.10$ & $<0.04$ & $>2265$ \\
\hline & $\mathrm{Na}$ & 8601 & 13.47 & 0.16 & 639 & 3451 & 1.86 & 0.05 & 1857 \\
\hline & $\mathrm{Ni}$ & 102 & $<0.10$ & $<0.10$ & $>1022$ & 41.0 & $<0.10$ & $<0.24$ & $>410$ \\
\hline & $\mathrm{P}$ & 7.1 & $<0.10$ & $<1.42$ & $>71$ & 2.8 & $<0.10$ & $<3.53$ & $>28$ \\
\hline & $\mathrm{Pb}$ & 25.3 & 0.24 & 0.94 & 106.9 & 10.1 & $<0.10$ & $<0.99$ & $>101$ \\
\hline & $\mathrm{S}^{*}$ & 22.2 & NA & $\mathrm{NC}$ & $\mathrm{NC}$ & 8.9 & NA & $\mathrm{NC}$ & $\mathrm{NC}$ \\
\hline & $\mathrm{Si}$ & 16038 & 9.04 & 0.06 & 1775 & 6435 & $<0.10$ & $<0.00$ & $>64349$ \\
\hline & $\mathrm{Ti}$ & 753 & 0.17 & 0.02 & 4382 & 302 & $<0.10$ & $<0.03$ & $>3021$ \\
\hline & $\mathrm{Zn}$ & 28.7 & $<0.10$ & $<0.35$ & $>287$ & 11.5 & $<0.10$ & $<0.87$ & $>115$ \\
\hline & $\mathrm{Zr}$ & 142 & $<0.10$ & $<0.07$ & $>1417$ & 56.8 & $<0.10$ & $<0.18$ & $>568$ \\
\hline \multirow{4}{*}{$\underset{\varpi}{\tilde{J}}$} & $\mathrm{~B}$ & 2745 & 11.32 & 0.41 & 242 & 1101 & 0.85 & 0.08 & 1295 \\
\hline & $\mathrm{Cl}$ & 10.2 & 10.26 & 101 & 1.0 & 4.1 & $<0.10$ & $<2.44$ & $>41$ \\
\hline & $\mathrm{F}$ & 2.6 & $<0.10$ & $<3.92$ & $>26$ & 1.0 & $<0.10$ & $<9.77$ & $>10$ \\
\hline & $\mathrm{S}$ & 22.2 & 2.14 & 9.66 & 10.4 & 8.9 & 0.56 & 6.30 & 15.9 \\
\hline & $\begin{array}{l}\text { \$ }-\mathrm{F} \\
\#-\mathrm{F} \\
*-\mathrm{C} \\
\mathrm{NA} \\
\mathrm{NC}\end{array}$ & $\begin{array}{l}\text { gravimet } \\
\text { rate calcu } \\
\text { lated fror } \\
\text { Availab } \\
\text { t Calcula }\end{array}$ & $\begin{array}{l}\text { nalysis o } \\
\text { from ta } \\
\text { alysis of }\end{array}$ & $\begin{array}{l}\text { ters and p } \\
\text { composi } \\
\text { er particu }\end{array}$ & $\begin{array}{l}\text { ticulate } \\
n \text { and s } \\
\text { e by we }\end{array}$ & $\begin{array}{l}\text { ic acid rin } \\
\text { y state pro } \\
\text { dissolution }\end{array}$ & ction rate & & \\
\hline
\end{tabular}


Table 6.1. DM100 Melter Off-Gas Emission Results from Tests with SRS SB19 Simulant Prepared by Harrell Industries (continued).

\begin{tabular}{|c|c|c|c|c|c|}
\hline & \multicolumn{4}{|c|}{ Test 3, $11.9 \mathrm{lpm}$ argon bubbling } \\
\hline & & \multicolumn{4}{|c|}{$\begin{array}{c}\text { 6/17/10 18:08 - 19:08 } \\
\text { 12.2\% Moisture; 105.9\% Isokinetic }\end{array}$} \\
\hline & & $\begin{array}{c}\text { Feed }^{\#} \\
(\mathrm{mg} / \mathrm{min})\end{array}$ & $\begin{array}{l}\text { Output } \\
(\mathrm{mg} / \mathrm{min})\end{array}$ & $\begin{array}{c}\% \\
\text { Emitted }\end{array}$ & DF \\
\hline \multirow{23}{*}{ 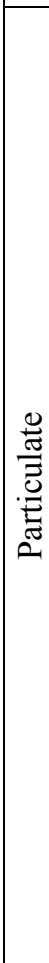 } & Total $^{\$}$ & 105874 & 91.6 & 0.09 & 1156 \\
\hline & $\mathrm{Al}$ & 7368 & 2.95 & 0.04 & 2499 \\
\hline & $\mathrm{B}$ & 2750 & 2.56 & 0.09 & 1072 \\
\hline & $\mathrm{Ba}$ & 67 & $<0.10$ & $<0.15$ & $>672$ \\
\hline & $\mathrm{Ca}$ & 823 & 0.47 & 0.06 & 1762 \\
\hline & $\mathrm{Cl}^{*}$ & 10 & 11.8 & $\mathrm{NC}$ & $\mathrm{NC}$ \\
\hline & $\mathrm{Cr}$ & 90 & 0.11 & 0.12 & 845 \\
\hline & $\mathrm{Cu}$ & 29 & $<0.10$ & $<0.35$ & $>286$ \\
\hline & $\mathrm{F}^{*}$ & 3 & 0.14 & 4.7 & 21 \\
\hline & $\mathrm{Fe}$ & 5310 & 1.70 & 0.03 & 3121 \\
\hline & $\mathrm{K}$ & 231 & 1.38 & 0.60 & 168 \\
\hline & $\mathrm{Li}$ & 2058 & 1.68 & 0.08 & 1224 \\
\hline & $\mathrm{Mg}$ & 92 & $<0.10$ & $<0.11$ & $>920$ \\
\hline & $\mathrm{Mn}$ & 565 & $<0.10$ & $<0.02$ & $>5655$ \\
\hline & $\mathrm{Na}$ & 8617 & 14.83 & 0.17 & 581 \\
\hline & $\mathrm{Ni}$ & 102 & $<0.10$ & $<0.10$ & $>1024$ \\
\hline & $\mathrm{P}$ & 7 & $<0.10$ & $<1.41$ & $>71$ \\
\hline & $\mathrm{Pb}$ & 25 & 0.15 & 0.59 & 168.6 \\
\hline & $\mathrm{S}^{*}$ & 22 & 5.7 & 25.9 & 3.9 \\
\hline & $\mathrm{Si}$ & 16068 & 8.84 & 0.06 & 1818 \\
\hline & $\mathrm{Ti}$ & 754 & 0.25 & 0.03 & 3003 \\
\hline & $\mathrm{Zn}$ & 29 & $<0.10$ & $<0.35$ & $>287$ \\
\hline & $\mathrm{Zr}$ & 142 & $<0.10$ & $<0.07$ & $>1419$ \\
\hline \multirow{4}{*}{$\underset{\overparen{E}}{\mathscr{E}}$} & $\mathrm{B}$ & 2750 & 13.8 & 0.50 & 200 \\
\hline & $\mathrm{Cl}$ & 10 & 1.21 & 11.8 & 8.5 \\
\hline & $\mathrm{F}$ & 3 & $<0.10$ & $<3.91$ & $>26$ \\
\hline & $\mathrm{S}$ & 22 & 3.38 & 15.24 & 6.6 \\
\hline
\end{tabular}

$\$$ - From gravimetric analysis of filters and particulate nitric acid rinses

\# - Feed rate calculated from target composition and steady state production rate

* - Calculated from analysis of filter particulate by water dissolution

NC - Not Calculated 
Table 6.2. DM100 Melter Off-Gas Emission Results from Tests with SRS SB19 Simulant Prepared by NOAH.

\begin{tabular}{|c|c|c|c|c|c|c|c|c|c|}
\hline & \multicolumn{4}{|c|}{ Test $4,8.5 \mathrm{lpm}$ bubbling } & \multicolumn{4}{|c|}{ Test 5, $0 \mathrm{lpm}$ bubbling } \\
\hline & & \multicolumn{4}{|c|}{$\begin{array}{c}\text { 7/13/10 19:13 - 20:13 } \\
12.8 \% \text { Moisture; } 106.2 \% \text { Isokinetic }\end{array}$} & \multicolumn{4}{|c|}{$\begin{array}{c}\text { 7/16/10 12:26 - 13:26 } \\
6.3 \% \text { Moisture; } 107.2 \% \text { Isokinetic }\end{array}$} \\
\hline & & $\begin{array}{c}\text { Feed }^{\#} \\
(\mathrm{mg} / \mathrm{min})\end{array}$ & $\begin{array}{l}\text { Output } \\
(\mathrm{mg} / \mathrm{min})\end{array}$ & $\begin{array}{c}\% \\
\text { Emitted }\end{array}$ & DF & $\begin{array}{c}\text { Feed }^{\#} \\
(\mathrm{mg} / \mathrm{min})\end{array}$ & $\begin{array}{l}\text { Output } \\
(\mathrm{mg} / \mathrm{min})\end{array}$ & $\begin{array}{c}\% \\
\text { Emitted }\end{array}$ & DF \\
\hline \multirow{23}{*}{ 苟 } & Total $^{\$}$ & 114081 & 1552 & 1.36 & 73 & 35629 & 201 & 0.56 & 178 \\
\hline & $\mathrm{Al}$ & 7289 & 139 & 1.90 & 52.5 & 2042 & 21.2 & 1.04 & 96.4 \\
\hline & $\mathrm{B}$ & 2720 & 57.0 & 2.09 & 47.7 & 762 & 8.06 & 1.06 & 94.5 \\
\hline & $\mathrm{Ba}$ & 66 & 2.57 & 3.86 & 25.9 & 18.6 & 0.27 & 1.46 & 68.7 \\
\hline & $\mathrm{Ca}$ & 814 & 27.6 & 3.39 & 29.5 & 228 & 3.37 & 1.48 & 67.6 \\
\hline & $\mathrm{Cl}^{*}$ & 10 & 17.4 & $\mathrm{NC}$ & $\mathrm{NC}$ & 2.8 & 1.57 & 56 & 1.8 \\
\hline & $\mathrm{Cr}$ & 89 & 4.02 & 4.50 & 22.2 & 25.0 & 0.19 & 0.76 & 132 \\
\hline & $\mathrm{Cu}$ & 28 & 0.41 & 1.44 & 69.5 & 7.9 & $<0.10$ & $<1.26$ & $>79$ \\
\hline & $\mathrm{F}^{*}$ & 3 & 3.35 & $\mathrm{NC}$ & $\mathrm{NC}$ & 0.7 & 0.34 & 49 & 2.1 \\
\hline & $\mathrm{Fe}$ & 5252 & 169 & 3.23 & 31.0 & 1471 & 22.5 & 1.53 & 65.5 \\
\hline & $\mathrm{K}$ & 229 & 7.29 & 3.18 & 31.4 & 64.1 & 0.83 & 1.29 & 77.5 \\
\hline & $\mathrm{Li}$ & 2036 & 19.6 & 0.96 & 104.0 & 570 & 2.19 & 0.38 & 261 \\
\hline & $\mathrm{Mg}$ & 91 & 5.86 & 6.44 & 15.5 & 25 & 0.71 & 2.79 & 35.9 \\
\hline & $\mathrm{Mn}$ & 559 & 19.0 & 3.39 & 29.5 & 157 & 2.35 & 1.50 & 66.7 \\
\hline & $\mathrm{Na}$ & 8524 & 225 & 2.64 & 37.8 & 2387 & 27.8 & 1.17 & 85.8 \\
\hline & $\mathrm{Ni}$ & 101 & 2.00 & 1.97 & 50.8 & 28.4 & $<0.10$ & $<0.35$ & $>284$ \\
\hline & $\mathrm{P}$ & 7 & 0.59 & 8.48 & 11.8 & 2.0 & $<0.10$ & $<5.11$ & $>20$ \\
\hline & $\mathrm{Pb}$ & 25 & 0.79 & 3.16 & 31.6 & 7.0 & $<0.10$ & $<1.43$ & $>70$ \\
\hline & $\mathrm{S}^{*}$ & 22 & 17 & 77 & 1.3 & 6.1 & 1.7 & 28 & 3.6 \\
\hline & $\mathrm{Si}$ & 15894 & 76.8 & 0.48 & 207 & 4452 & 10.1 & 0.23 & 443 \\
\hline & $\mathrm{Ti}$ & 746 & 26.2 & 3.51 & 28.5 & 209 & 3.11 & 1.49 & 67.1 \\
\hline & $\mathrm{Zn}$ & 28 & 0.92 & 3.22 & 31.0 & 8.0 & $<0.10$ & $<1.26$ & $>80$ \\
\hline & $\mathrm{Zr}$ & 140 & 2.42 & 1.72 & 58.0 & 39 & 0.26 & 0.66 & 152 \\
\hline \multirow{4}{*}{ 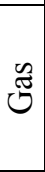 } & $\mathrm{B}$ & 2720 & 0.42 & 0.02 & 6492 & 762 & 0.37 & 0.05 & 2037 \\
\hline & $\mathrm{Cl}$ & 10 & $<0.10$ & $<0.99$ & $>101$ & 3 & $<0.10$ & $<3.53$ & $>28$ \\
\hline & $\mathrm{F}$ & 3 & $<0.10$ & $<3.95$ & $>25$ & 0.7 & $<0.10$ & $<14.1$ & $>7$ \\
\hline & $\mathrm{S}$ & 22 & 0.62 & 2.83 & 35.3 & 6.1 & 0.70 & 11.4 & 8.8 \\
\hline
\end{tabular}

$\$$ - From gravimetric analysis of filters and particulate nitric acid rinses

\# - Feed rate calculated from target composition and steady state production rate

* - Calculated from analysis of filter particulate by water dissolution

NC - Not Calculated 
Table 6.3. Comparison of Particulate Carryover During Tests With and Without Bubbling.

\begin{tabular}{|c|c|c|c|c|}
\hline Melter & Feed & $\begin{array}{l}\text { Bubbling } \\
\text { (lpm) }\end{array}$ & $\begin{array}{c}\% \text { Particulate } \\
\text { Carryover }\end{array}$ & $\begin{array}{c}\text { Ratio of Particulate } \\
\text { Carryover with and } \\
\text { without Bubbling }\end{array}$ \\
\hline \multirow{2}{*}{ DM100 } & \multirow{2}{*}{ AZ-101 [8] } & $<0.1$ & 0.10 & \multirow{2}{*}{2.60} \\
\hline & & 5.7 & 0.26 & \\
\hline \multirow{6}{*}{ DM1200 } & \multirow{2}{*}{ AZ-101 [13] } & $<4$ & 0.05 & \multirow{2}{*}{5.20} \\
\hline & & 47 & 0.26 & \\
\hline & \multirow{2}{*}{ AZ-101 + Frit [14] } & $<4$ & 0.13 & \multirow{2}{*}{1.77} \\
\hline & & 60 & 0.23 & \\
\hline & \multirow{2}{*}{ AZ-101 [12] } & $<4$ & 1.18 & \multirow{2}{*}{0.44} \\
\hline & & 65 & 0.78 & \\
\hline \multirow{7}{*}{ DM100 } & \multirow{2}{*}{ SRS Sludge Batch 4 [33] } & 0 & 0.26 & \multirow{2}{*}{8.19} \\
\hline & & 15.3 & 2.13 & \\
\hline & \multirow{3}{*}{$\begin{array}{c}\text { SRS SB19 } \\
\text { Harrell Industries }\end{array}$} & 0 & 0.04 & \multirow{3}{*}{2.13} \\
\hline & & 11.8 & 0.08 & \\
\hline & & 11.9 argon & 0.09 & \\
\hline & \multirow{2}{*}{$\begin{array}{c}\text { SRS SB19 } \\
\text { NOAH }\end{array}$} & 0 & 0.54 & \multirow{2}{*}{2.52} \\
\hline & & 8.5 & 1.36 & \\
\hline
\end{tabular}

NC - Not Calculated 
Table 6.4. Average Concentrations [ppmv] of Selected Species in Off-Gas Measured by FTIR Spectroscopy for SRS SB19 Tests.

\begin{tabular}{|c|c|c|c|c|c|c|c|c|c|c|}
\hline \multirow{2}{*}{ Test } & \multicolumn{2}{|c|}{$\mathbf{1}$} & \multicolumn{2}{c|}{$\mathbf{2}$} & \multicolumn{2}{c|}{3} & \multicolumn{2}{c|}{$\mathbf{4}$} & \multicolumn{2}{c|}{$\mathbf{5}$} \\
\cline { 2 - 12 } & Melter & Stack & Melter & Stack & Melter & Stack & Melter & Stack & Melter & Stack \\
\hline $\mathrm{N}_{2} \mathrm{O}$ & 100 & 17.8 & 63 & 8.7 & 147 & 18.4 & 696 & 74.0 & 355 & 32 \\
\hline $\mathrm{NO}$ & 1805 & 323 & 1076 & 150 & 3022 & 378 & 3983 & 424 & 1805 & 162 \\
\hline $\mathrm{NO}_{2}$ & 411 & 73.5 & 117 & 16.3 & 252 & 31.5 & 256 & 27.2 & 156 & 14 \\
\hline $\mathrm{NH}_{3}$ & $<5.6$ & $<1.0$ & $<7.2$ & $<1.0$ & $<8.0$ & $<1.0$ & 12 & 1.3 & $<11.2$ & $<1.0$ \\
\hline $\mathrm{H}_{2} \mathrm{O}[\%]$ & 34 & 6.2 & 24 & 3.3 & 49 & 6.2 & 67 & 7.1 & 43 & 3.8 \\
\hline $\mathrm{CO}_{2}[\%]$ & 1.240 & 0.222 & 0.857 & 0.119 & 1.851 & 0.231 & 2.950 & 0.310 & 1.742 & 0.156 \\
\hline $\mathrm{Nitrous} \mathrm{Acid}^{2}$ & $<5.6$ & $<1.0$ & $<7.2$ & $<1.0$ & $<8.0$ & $<1.0$ & $<9.4$ & $<1.0$ & $<11.2$ & $<1.0$ \\
\hline $\mathrm{Nitric} \mathrm{Acid}^{2}$ & $<5.6$ & $<1.0$ & $<7.2$ & $<1.0$ & $<8.0$ & $<1.0$ & $<9.4$ & $<1.0$ & $<11.2$ & $<1.0$ \\
\hline $\mathrm{CO}$ & 443 & 79.3 & 257 & 35.7 & 585 & 73.1 & 1135 & 121 & 465 & 42 \\
\hline $\mathrm{HCN}$ & $<5.6$ & $<1.0$ & $<7.2$ & $<1.0$ & $<8.0$ & $<1.0$ & $<9.4$ & $<1.0$ & $<11.2$ & $<1.0$ \\
\hline $\mathrm{HCl}$ & $<5.6$ & $<1.0$ & $<7.2$ & $<1.0$ & $<8.0$ & $<1.0$ & $<9.4$ & $<1.0$ & $<11.2$ & $<1.0$ \\
\hline $\mathrm{SO}$ & $<5.6$ & $<1.0$ & $<7.2$ & $<1.0$ & $<8.0$ & $<1.0$ & $<9.4$ & $<1.0$ & $<11.2$ & $<1.0$ \\
\hline $\mathrm{HF}$ & 12 & 2.2 & 12 & 1.6 & 14 & 1.8 & $<9.4$ & $<1.0$ & $<11.2$ & $<1.0$ \\
\hline $\mathrm{H}$ & 341 & 61.0 & 244 & 34.0 & 216 & 27.0 & 103 & 11.0 & 56 & 5.0 \\
\hline
\end{tabular}

NA - Not applicable.

Note: Stack is point of measurement after particulate filtration. Melter concentration is calculated accounting for all dilutions prior to that point, including film cooler air. 


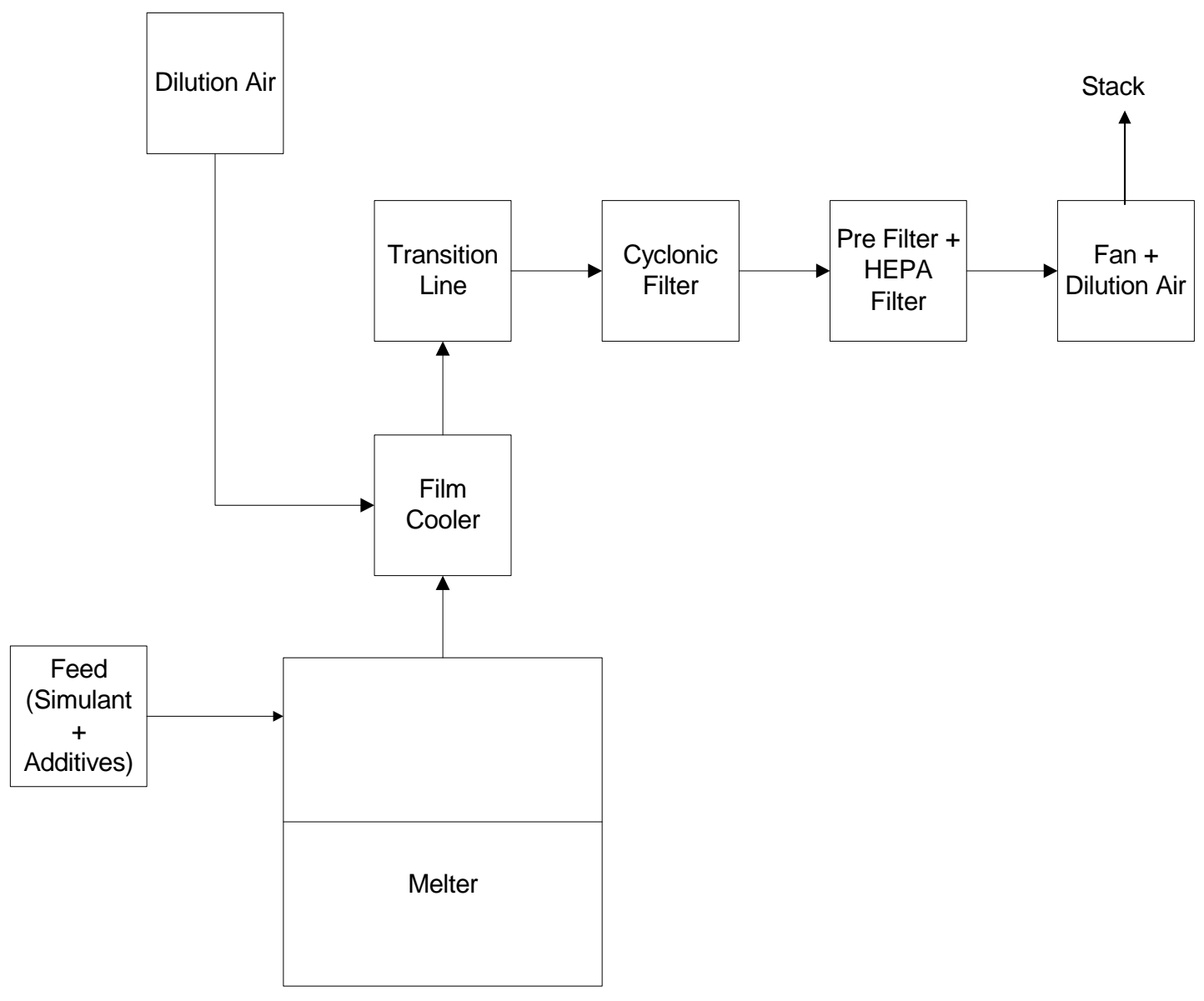

Figure 1.1. Schematic diagram of DuraMelter 100-BL vitrification system. 


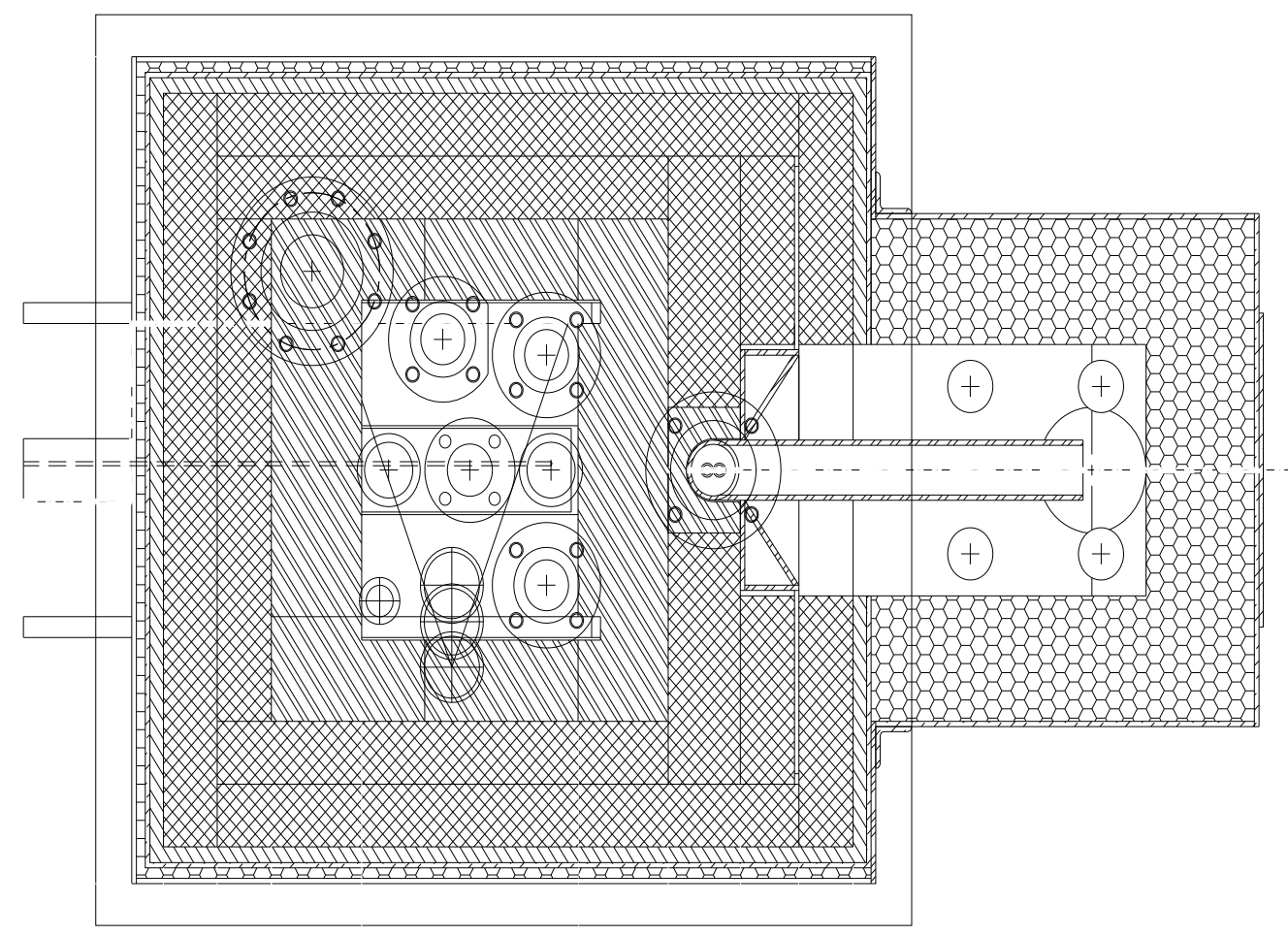

Figure 1.2.a. Schematic diagram showing cross-section through the DM100-BL melter. Plan view showing locations of lid ports. 


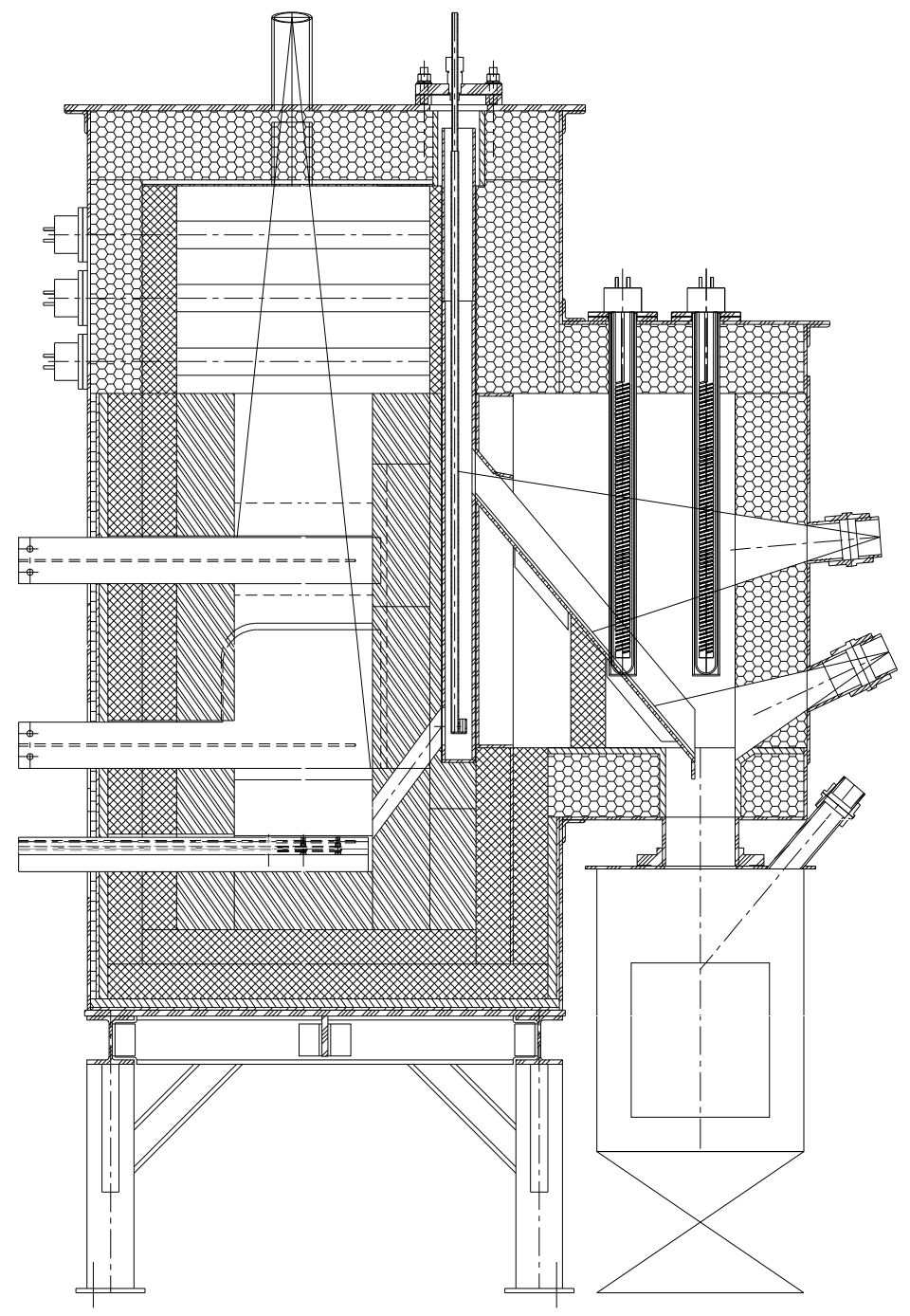

Figure 1.2.b. Schematic diagram showing cross-section through the DM100-BL melter. 
The Catholic University of America Vitreous State Laboratory
Glass Formulation Development and Testing for DWPFHigh- $\mathrm{Al}_{2} \mathrm{O}_{3} \mathrm{HLW}$ Sludges Final Report, VSL-10R1670-1, Rev. 0

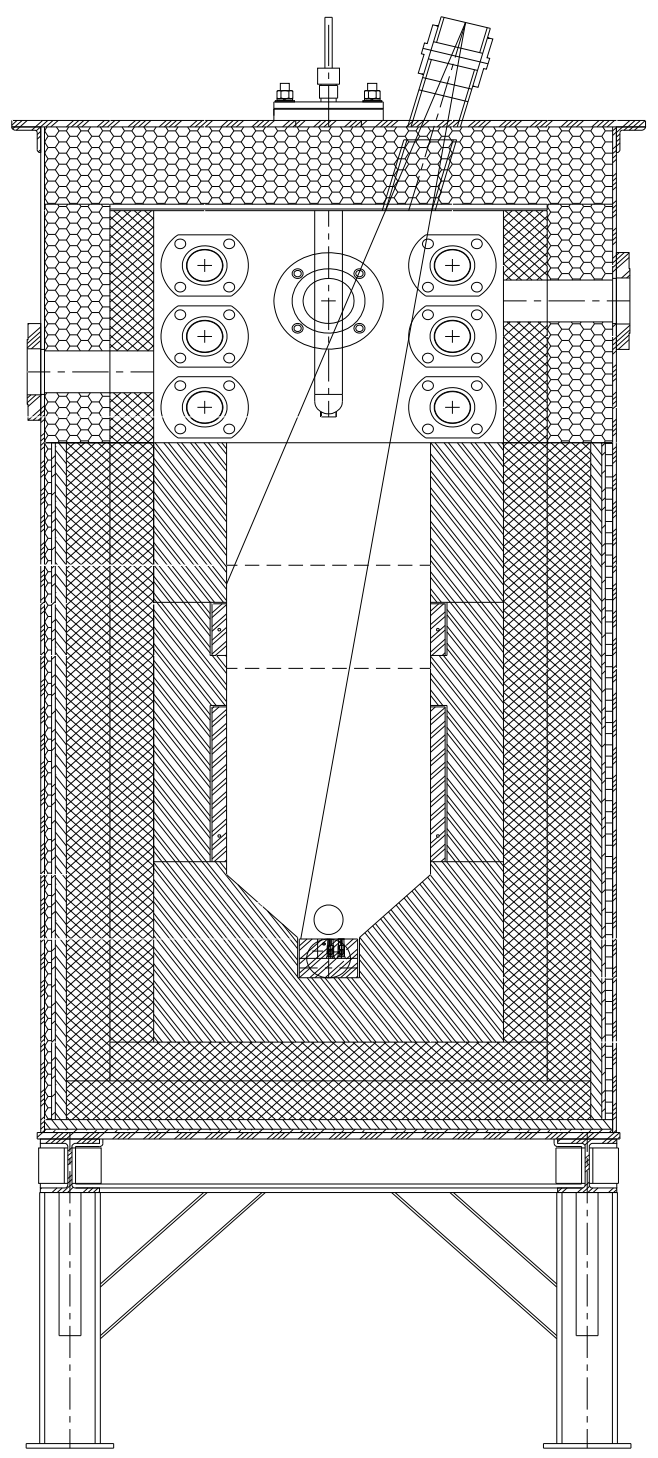

Figure 1.2.c. Schematic diagram showing cross-section through the DM100-BL melter. 


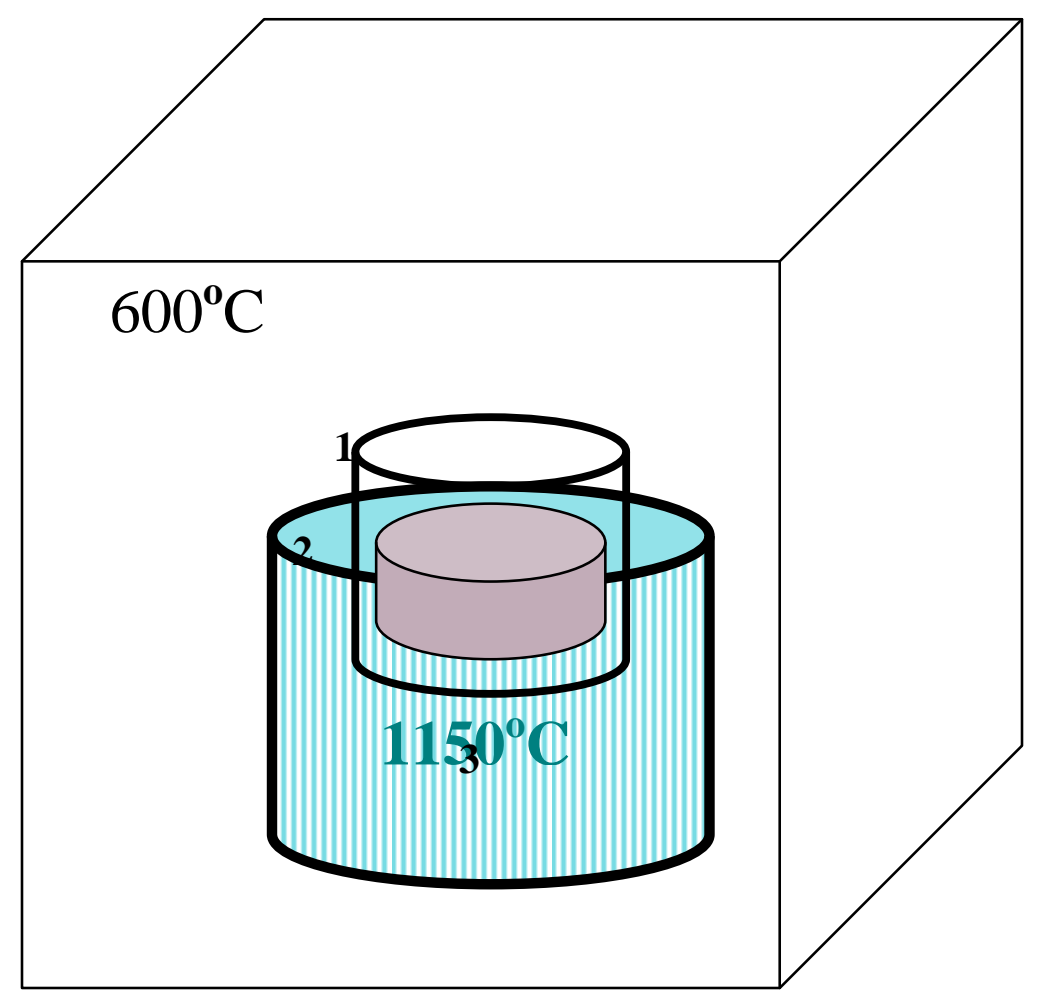

Figure 1.3. Schematic diagram of vertical gradient furnace (VGF) for feed conversion test (1=ceramic crucible half inside the local heater; $2=$ feed for 20 gram glass; $3=l o c a l$ heater at $1150^{\circ} \mathrm{C}$ ). 


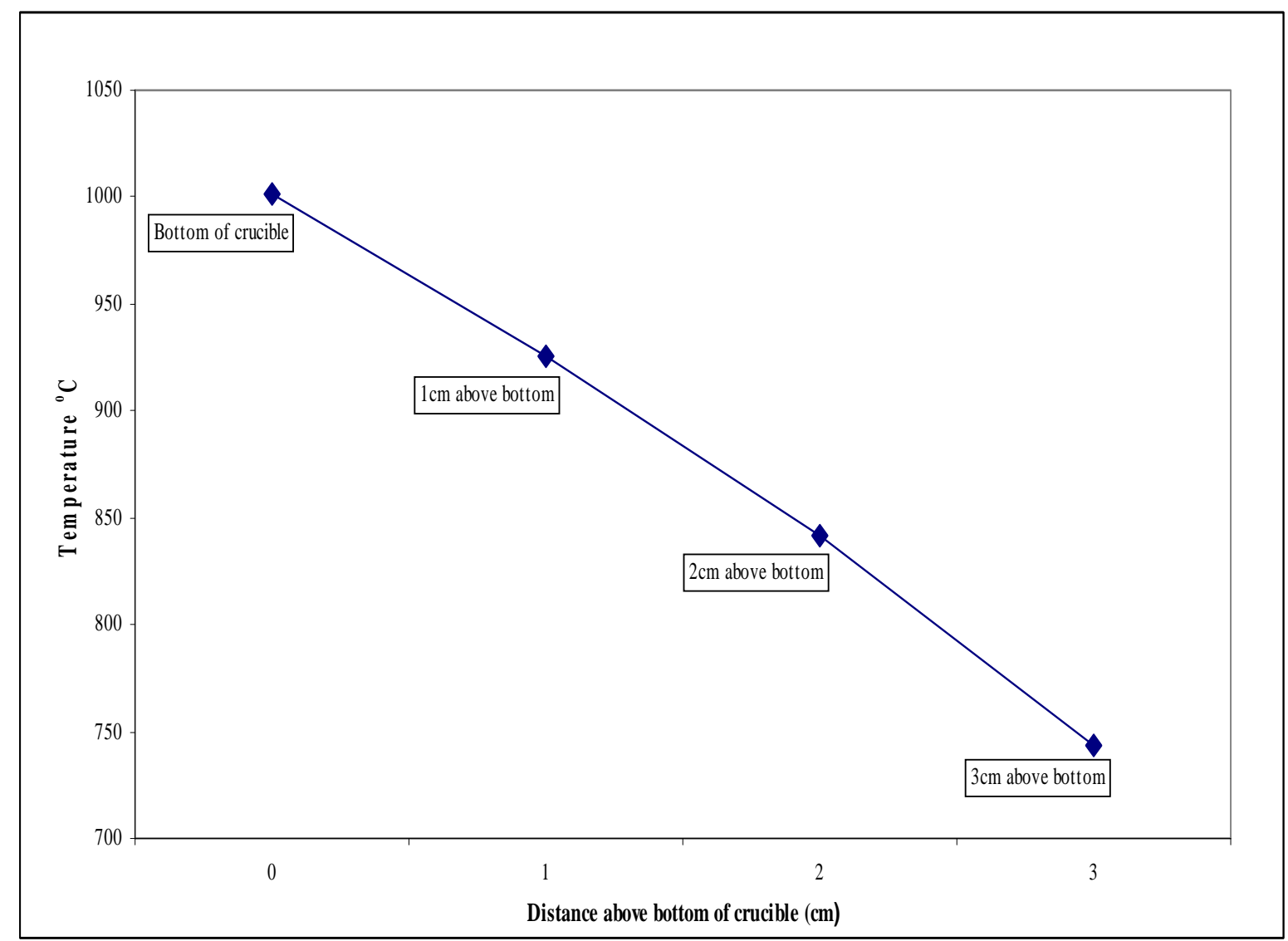

Figure 1.4. Temperature gradient inside the loaded ceramic crucible of the Vertical Gradient Furnace (VGF). 
The Catholic University of America Vitreous State Laboratory
Glass Formulation Development and Testing for DWPFHigh- $\mathrm{Al}_{2} \mathrm{O}_{3} \mathrm{HLW}$ Sludges Final Report, VSL-10R1670-1, Rev. 0

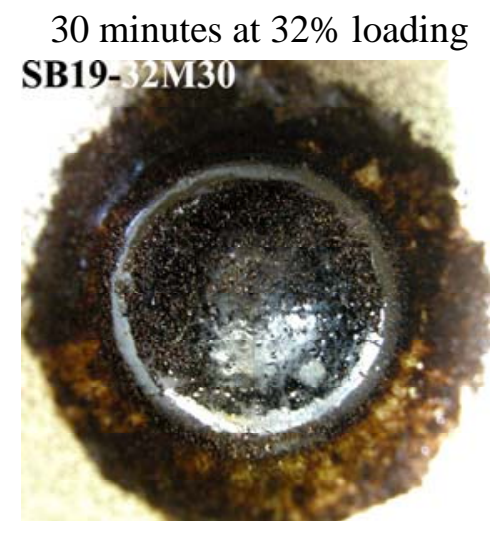

30 minutes at $35 \%$ loading

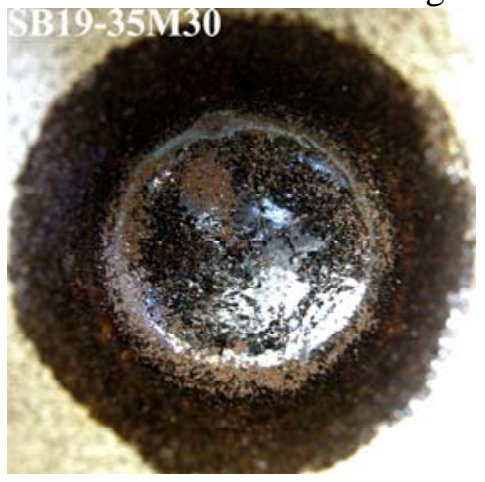

30 minutes at $38 \%$ loading

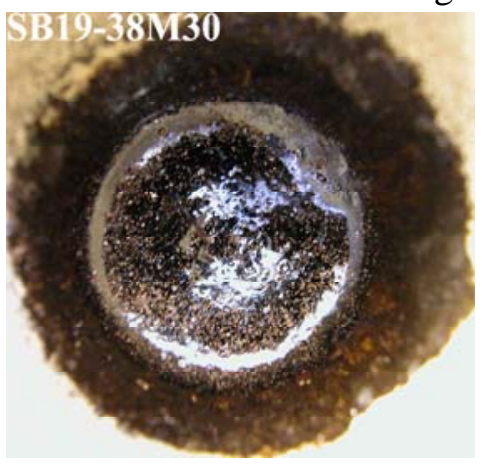

30 minutes at $48 \%$ loading

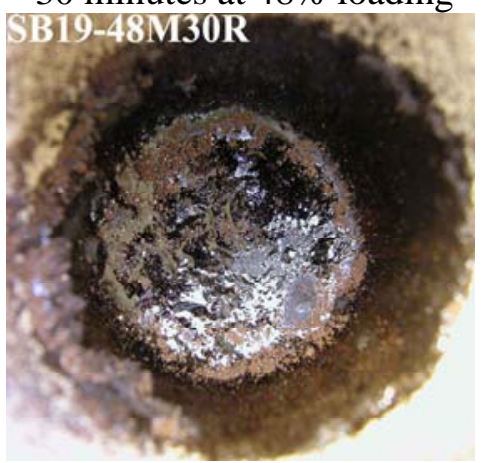

60 minutes at $32 \%$ loading

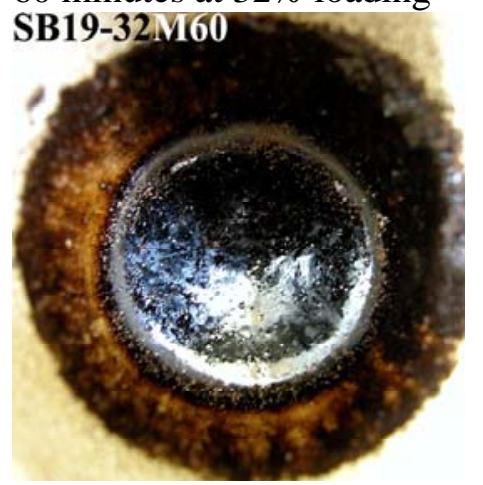

60 minutes at $35 \%$ loading

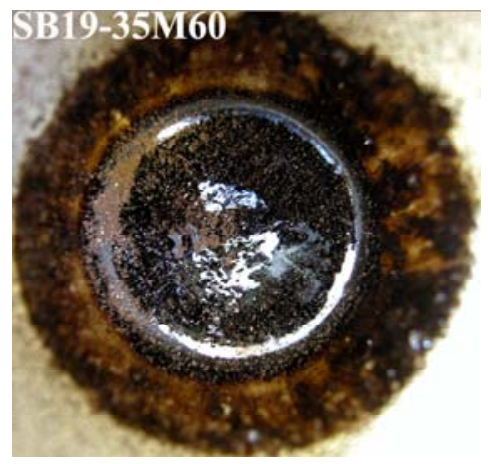

60 minutes at $38 \%$ loading SBI 19-381960

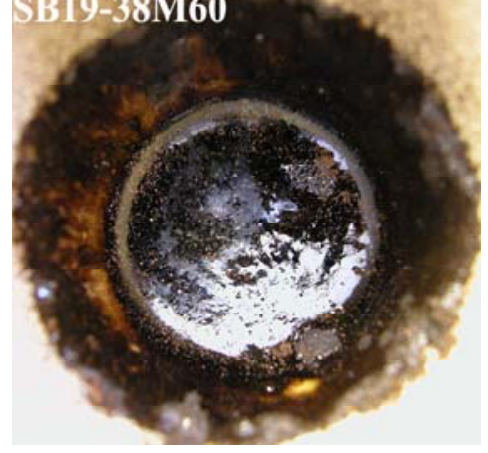

60 minutes at $48 \%$ loading

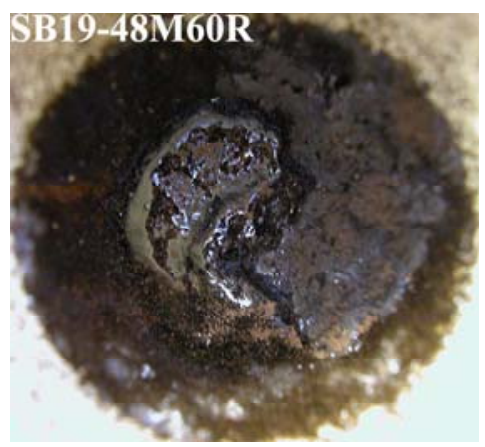

Figure 3.1. Top views of the melter feed blends after VGF experiments (30 and 60 minutes) with VS3 frit and SB19 simulant. 
The Catholic University of America Vitreous State Laboratory
Glass Formulation Development and Testing for DWPFHigh- $\mathrm{Al}_{2} \mathrm{O}_{3} \mathrm{HLW}$ Sludges Final Report, VSL-10R1670-1, Rev. 0
30 minutes at $32 \%$ loading SB19-32M30

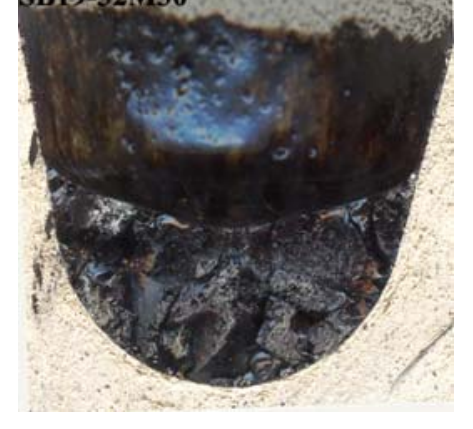

30 minutes at 35\% loading

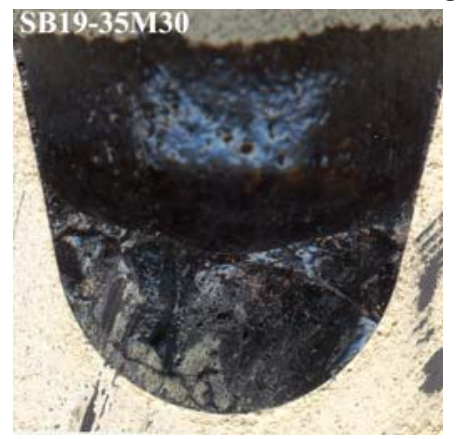

30 minutes at $38 \%$ loading

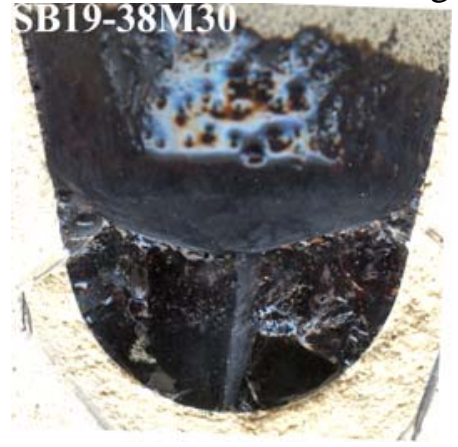

30 minutes at $48 \%$ loading

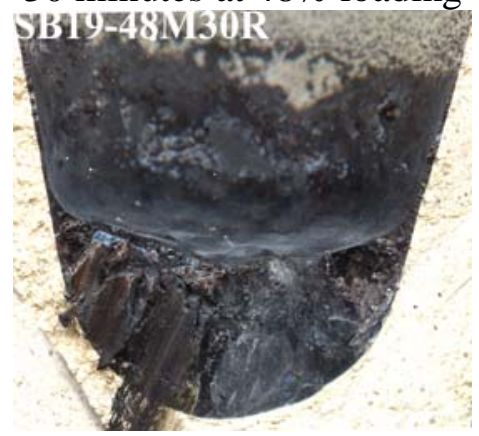

60 minutes at $32 \%$ loading

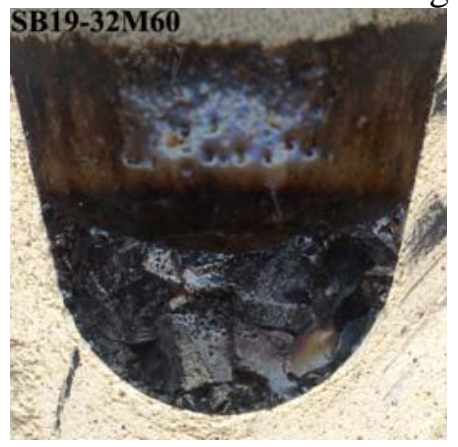

60 minutes at $35 \%$ loading

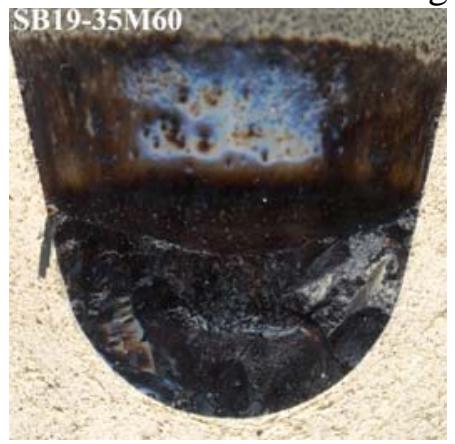

60 minutes at $38 \%$ loading

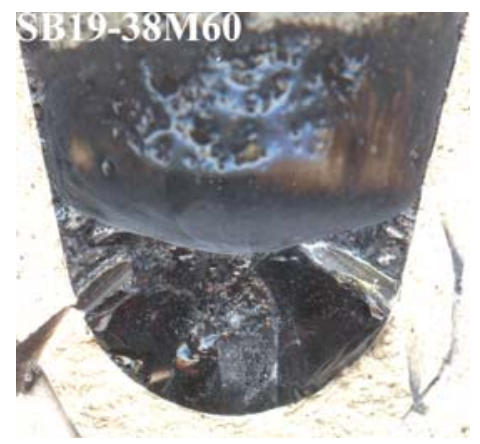

60 minutes at $48 \%$ loading

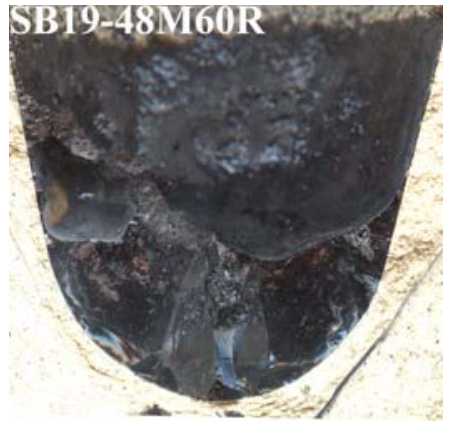

Figure 3.2. Cross section views of the melter feed blends after VGF experiments (30 and 60 minutes) with VS3 frit and SB19 simulant. 


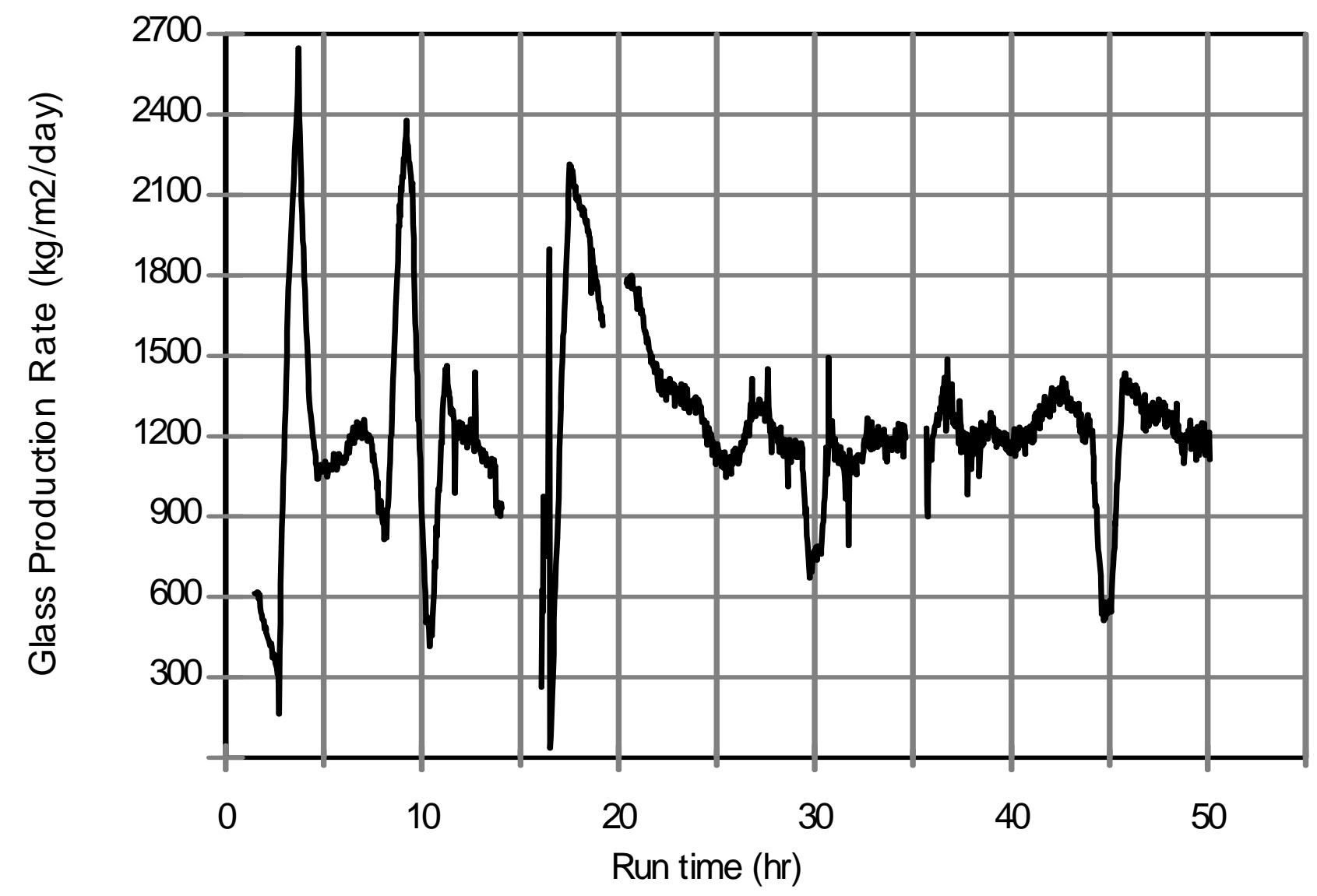

Figure 4.1.a. Glass production rates (hourly moving averages) for SRS SB19 Test 1. 


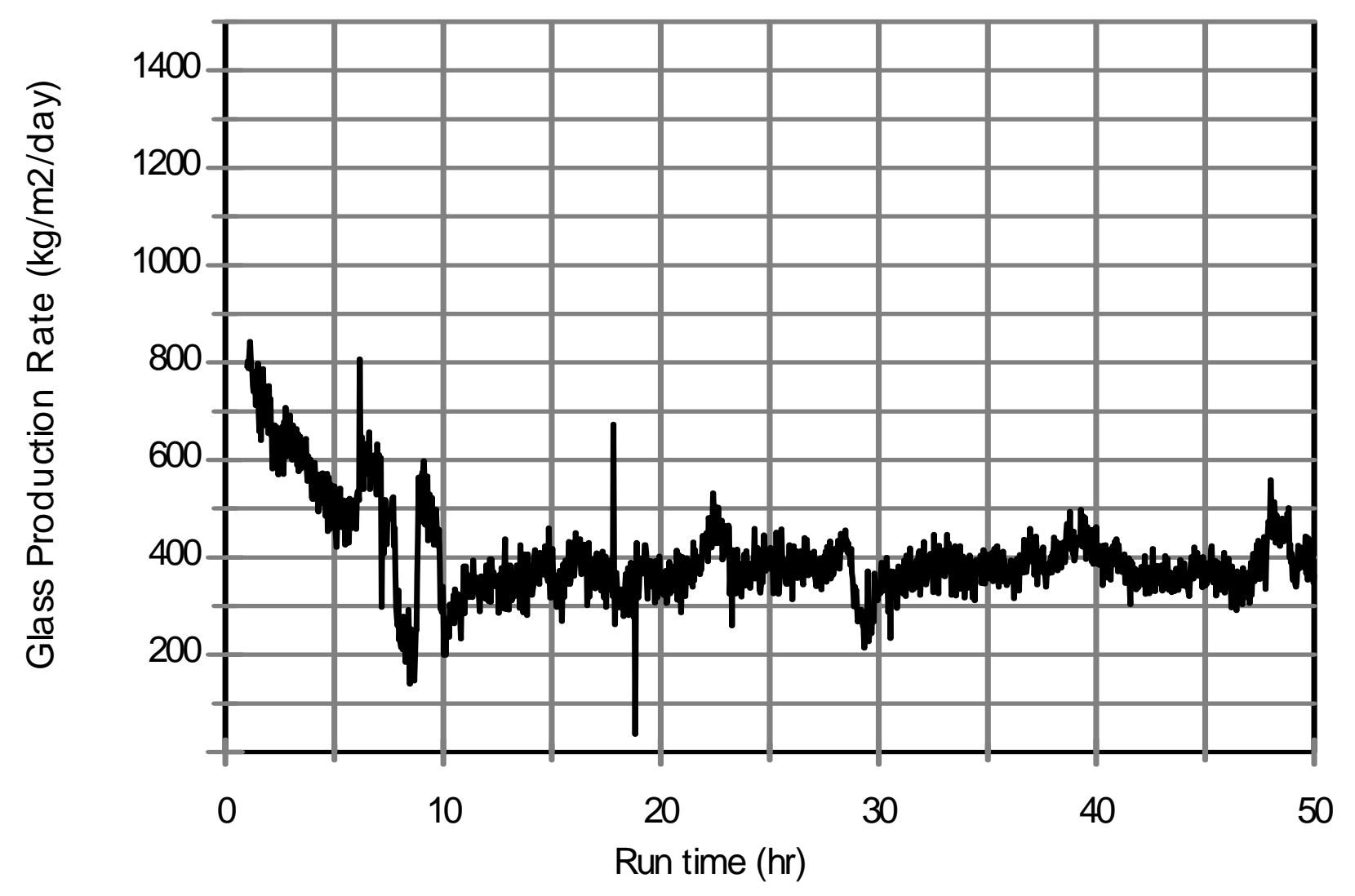

Figure 4.1.b. Glass production rates (hourly moving averages) for SRS SB19 Test 2. 


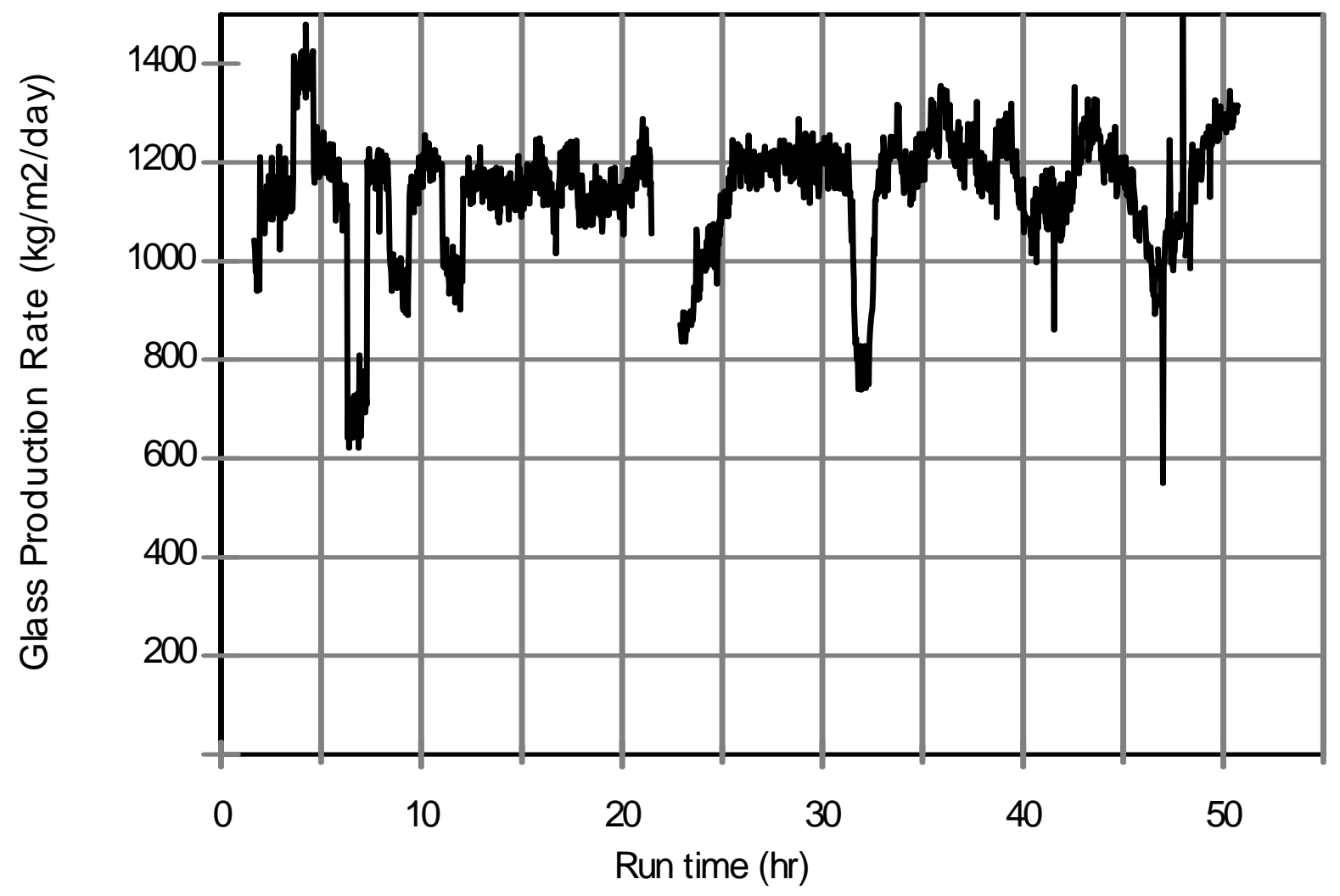

Figure 4.1.c. Glass production rates (hourly moving averages) for SRS SB19 Tests 3. 


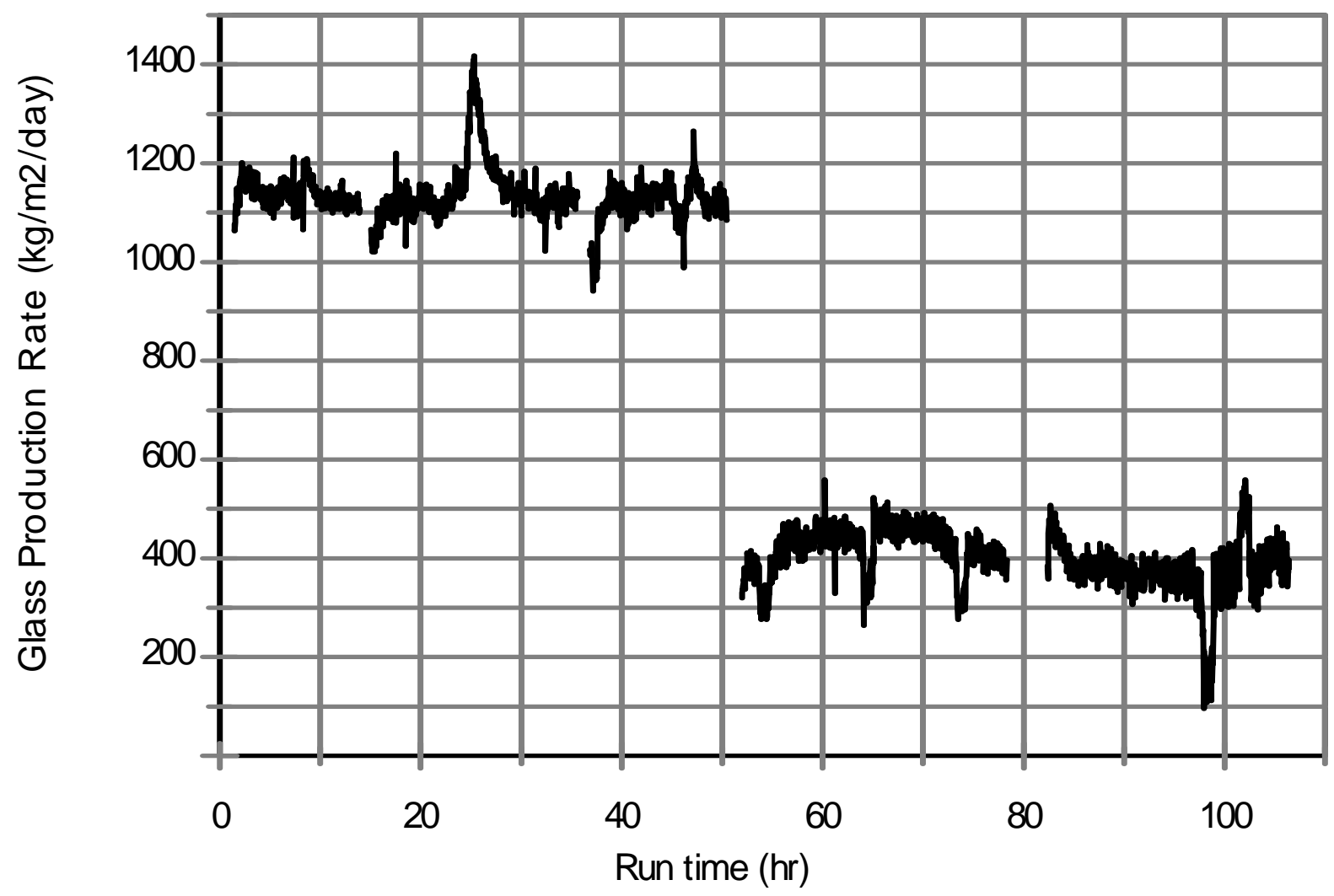

Figure 4.1.d. Glass production rates (hourly moving averages) for SRS SB19 Tests 4 and 5. 


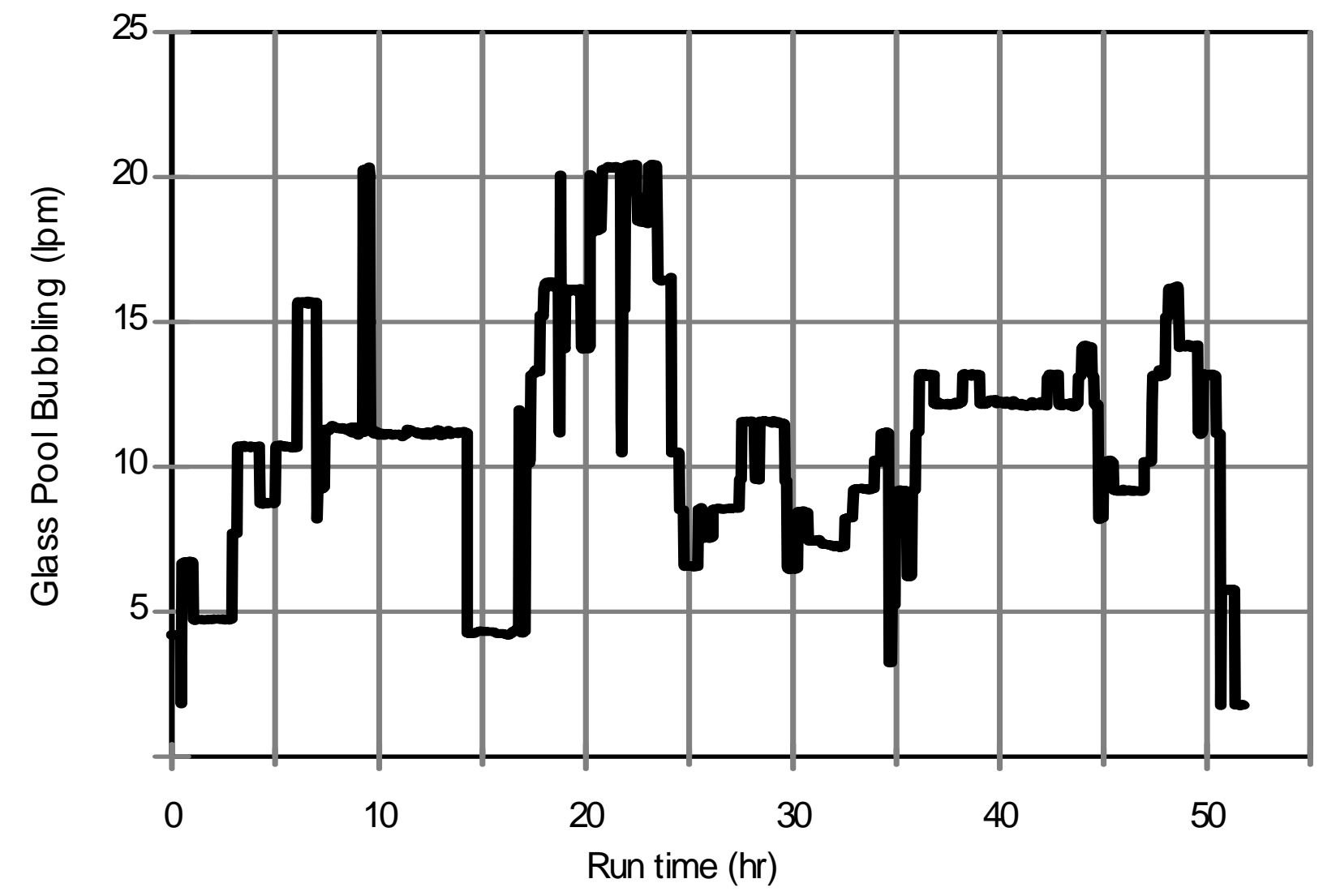

Figure 4.2.a. Glass pool bubbling rate for SRS SB19 Test 1. 


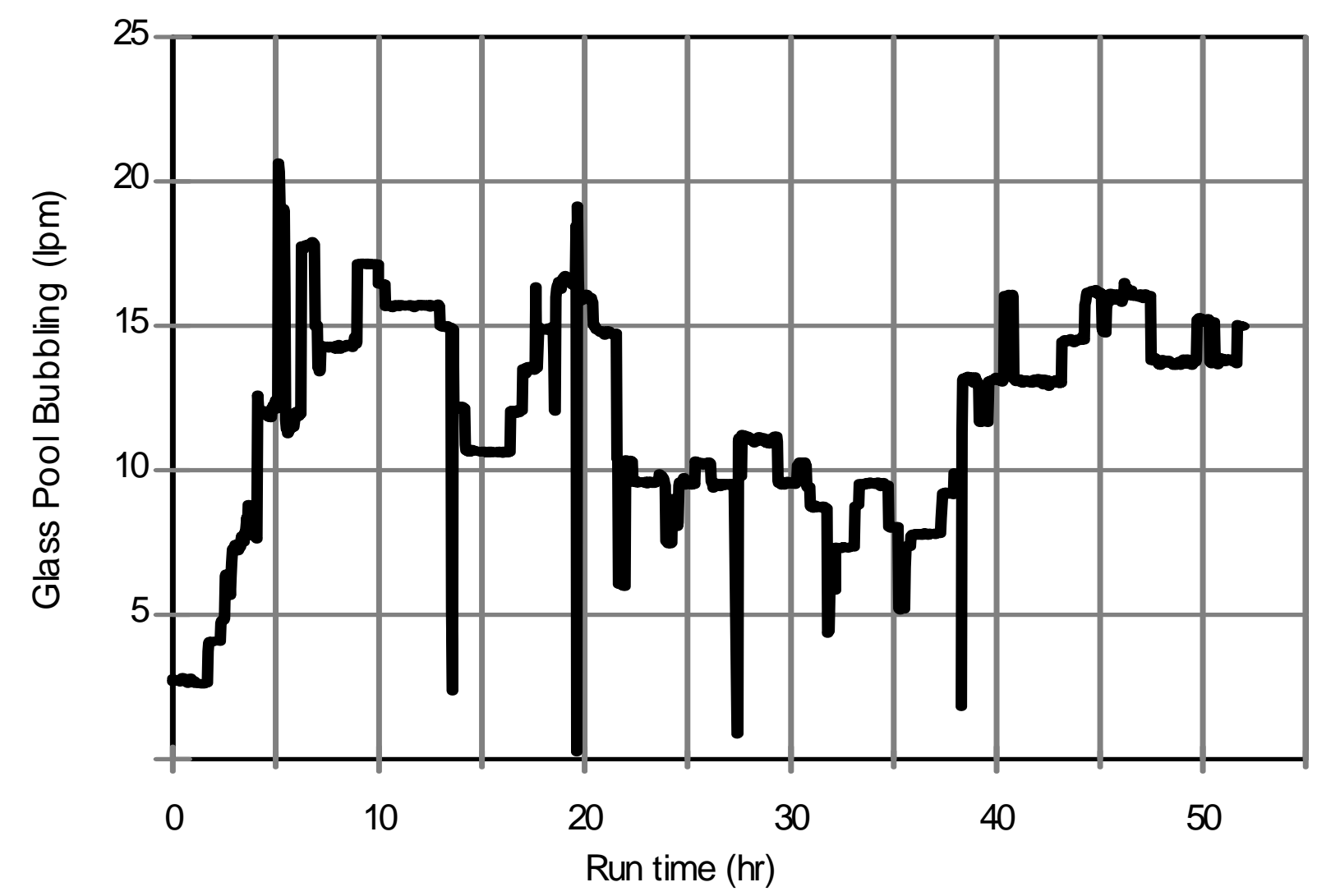

Figure 4.2.b. Glass pool bubbling rates for SRS SB19 Test 3. 


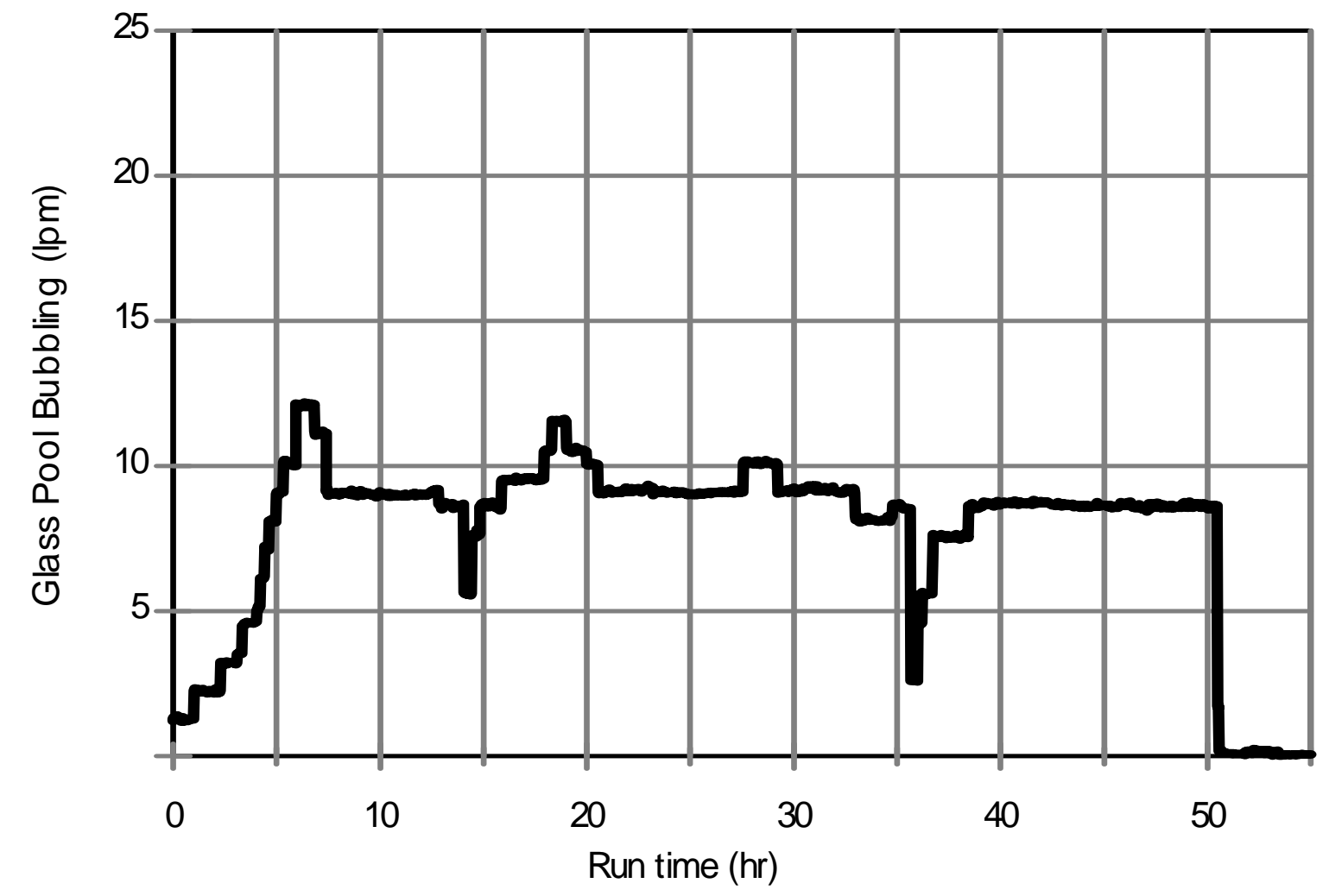

Figure 4.2.c. Glass pool bubbling rates for SRS SB19 Test 4. 


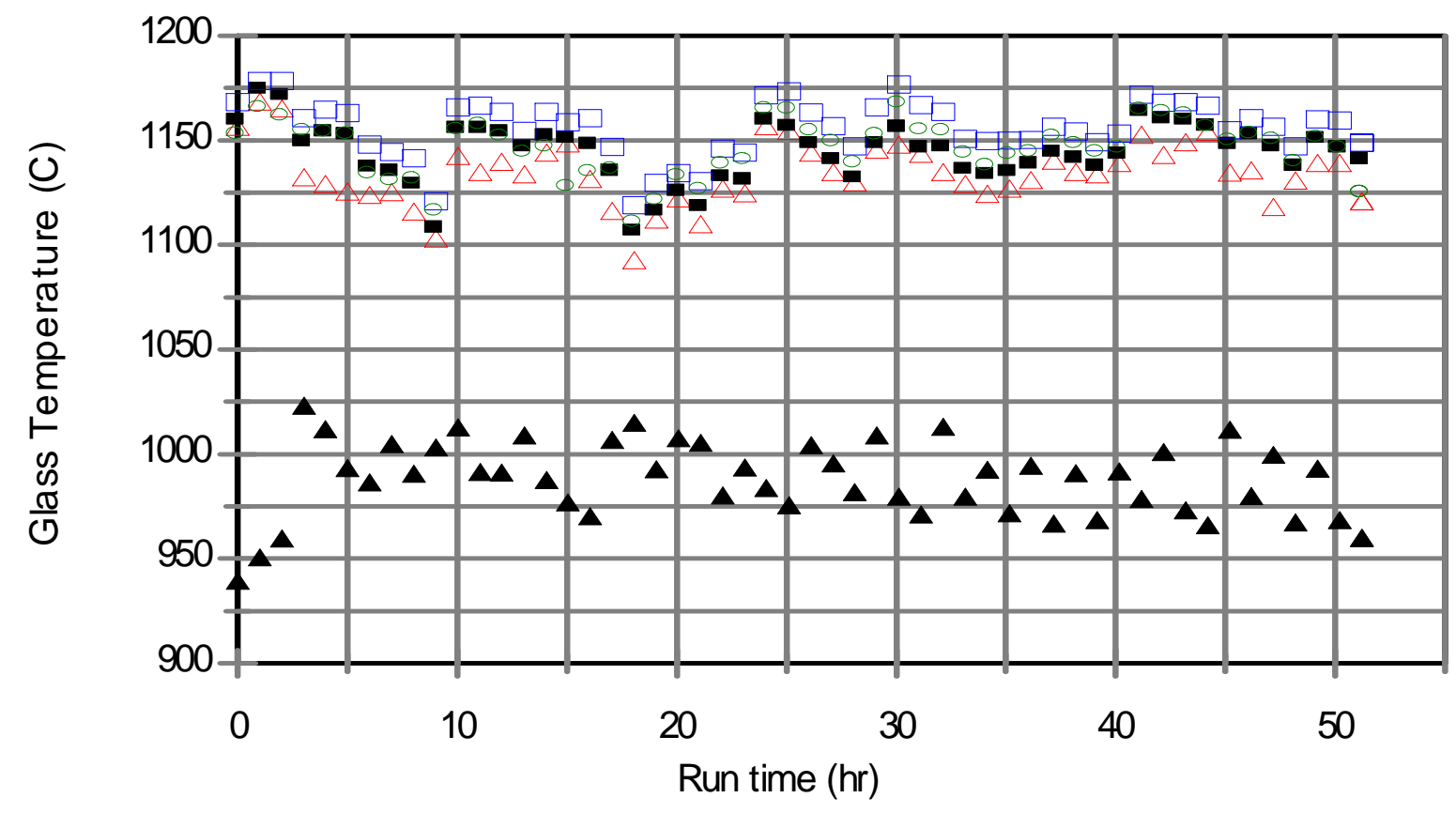
$\Delta \quad 27$ " frombottom
- 16 " frombottom
10" from bottom
- 5" frombottom
- Airlift

Figure 4.3.a. Glass temperatures (hourly averages) during SRS SB19 Test 1. 


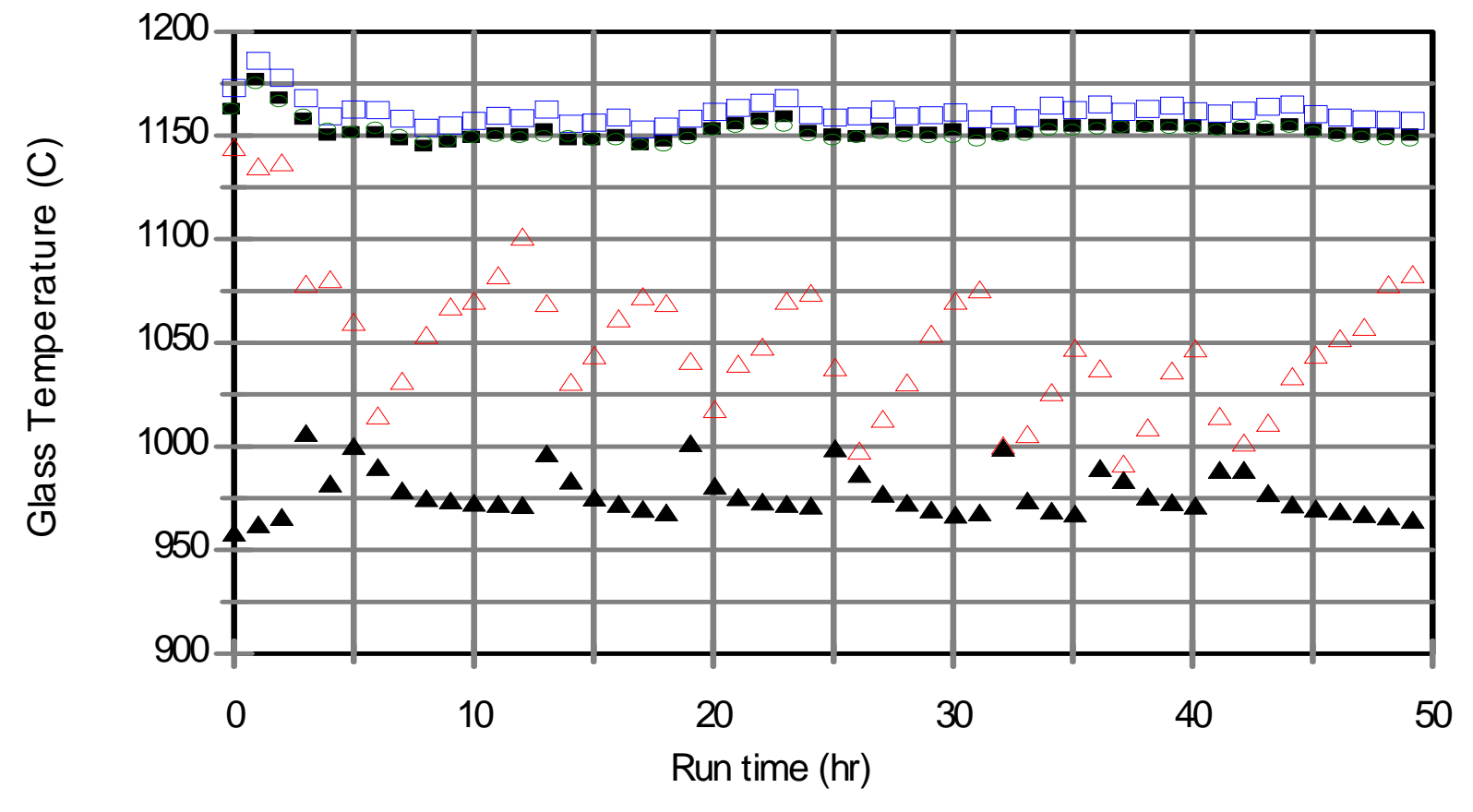
$\Delta \quad 27$ " frombottom
- 16 " frombottom
- 10" frombottom
- 5" frombottom
$\Delta$ Airlift

Figure 4.3.b. Glass temperatures (hourly averages) during SRS SB19 Test 2. 


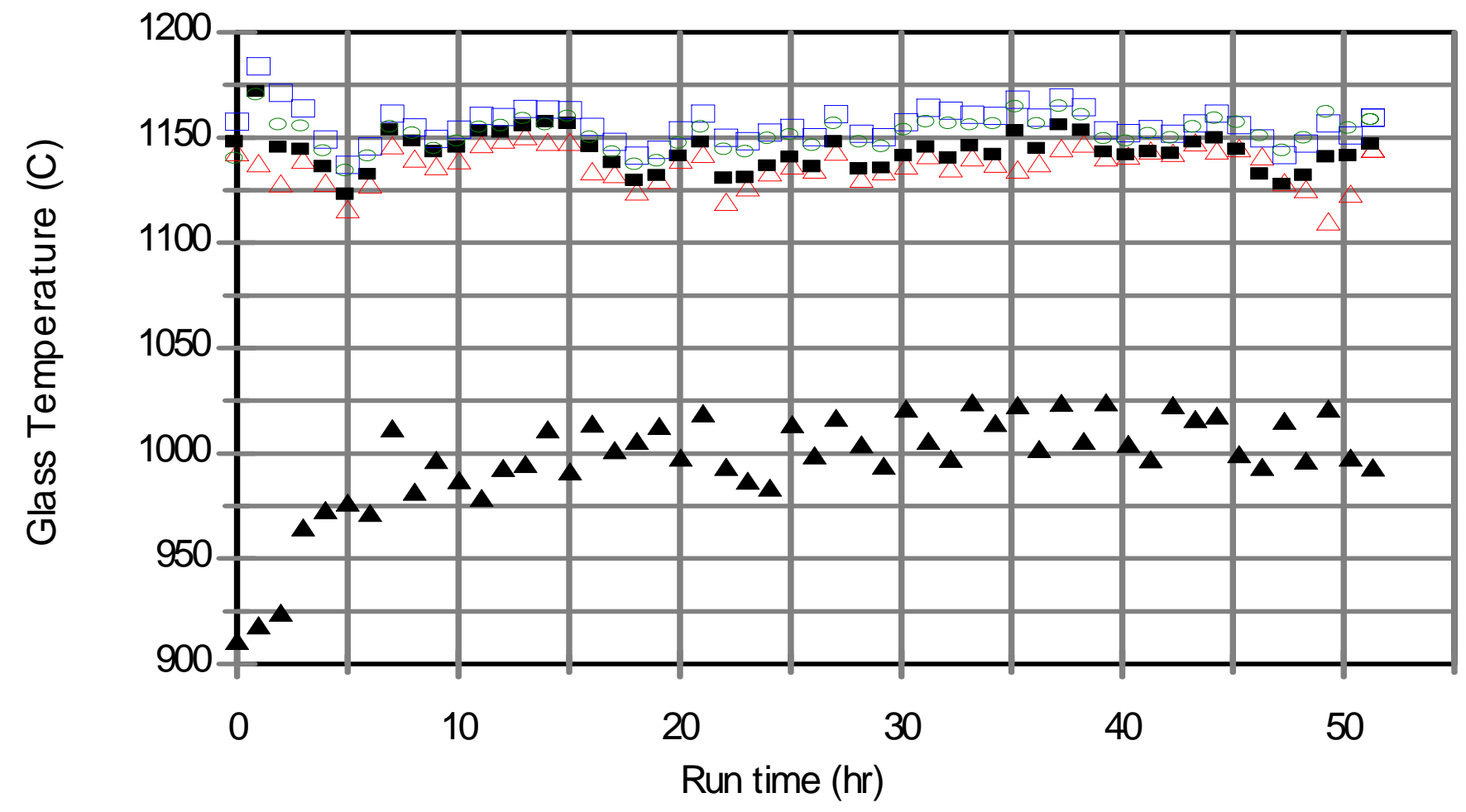
$\Delta \quad 27$ " from bottom
- 16 " from bottom
ㅁ 10 " from bottom
- 5 " frombottom
$\Delta \quad$ Airlift

Figure 4.3.c. Glass temperatures (hourly averages) during SRS SB19 Test 3. 


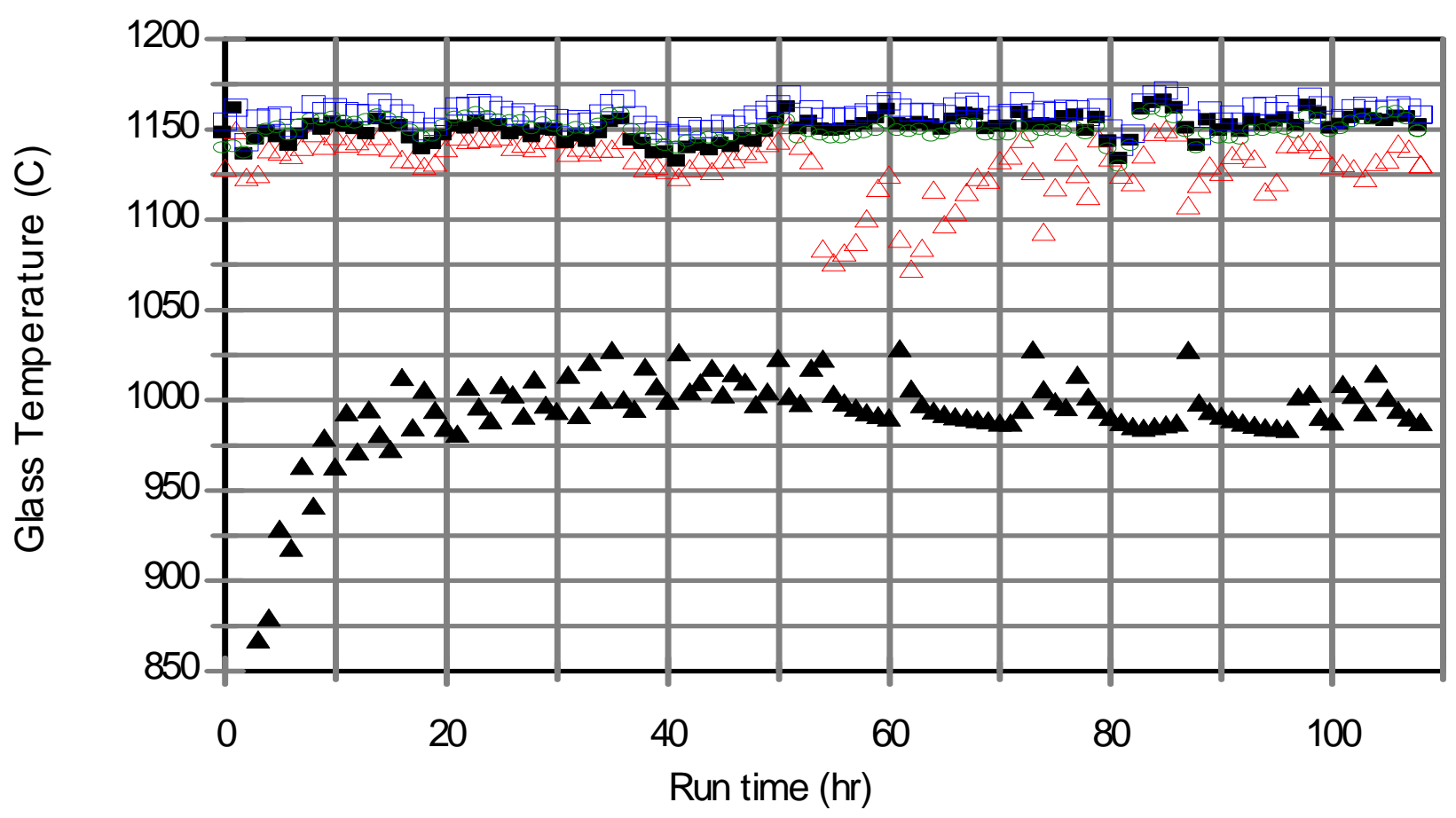
$\Delta \quad 27$ " from bottom
- $16^{\prime \prime}$ frombottom
ㅁ 10 " frombottom
- 5" frombottom
$\Delta$ Airlift

Figure 4.3.d. Glass temperatures (hourly averages) during SRS SB19 Tests 4 and 5. 


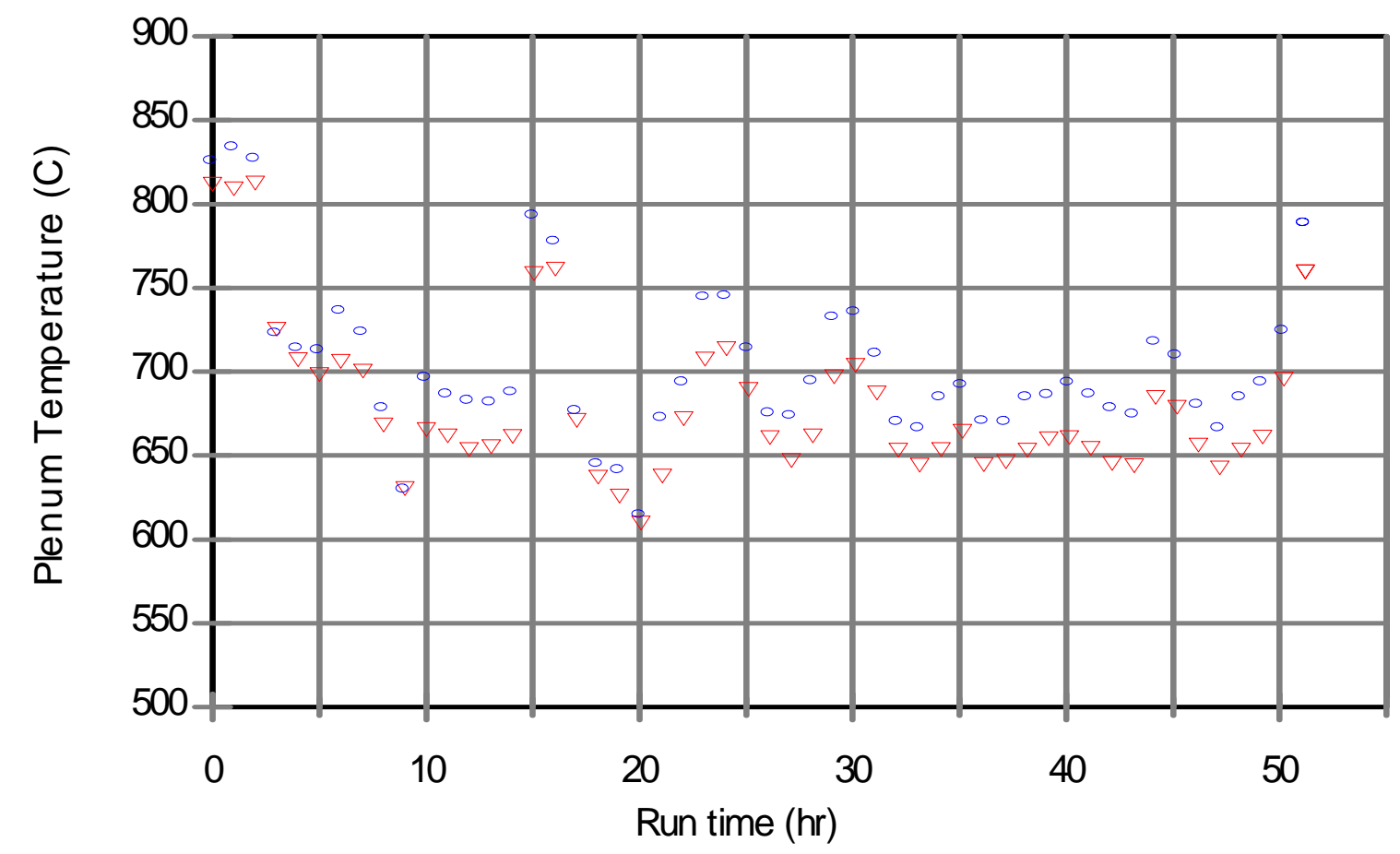

Figure 4.4.a. Plenum temperatures (hourly averages) during SRS SB19 Test 1. 


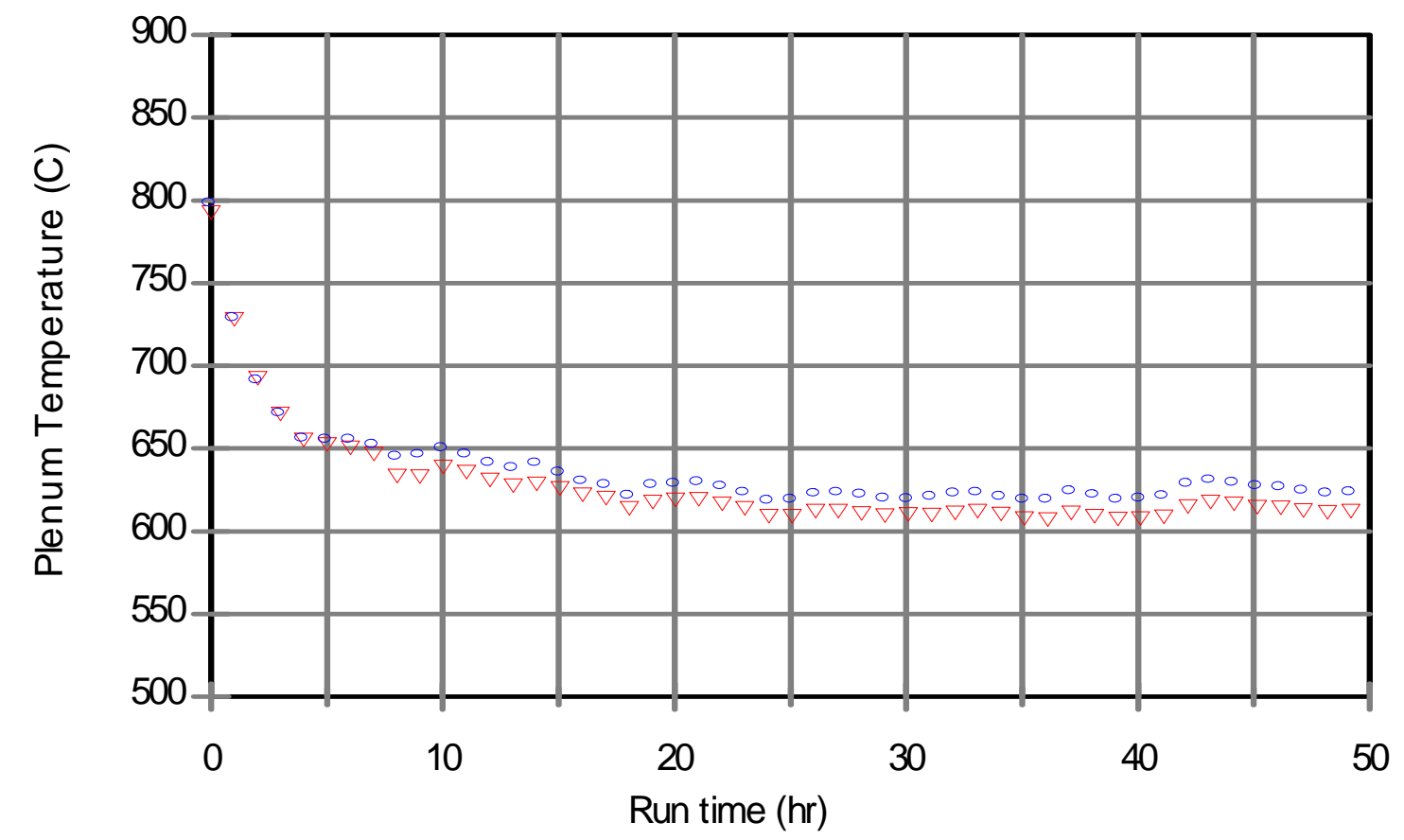

Figure 4.4.b. Plenum temperatures (hourly averages) during SRS SB19 Test 2. 


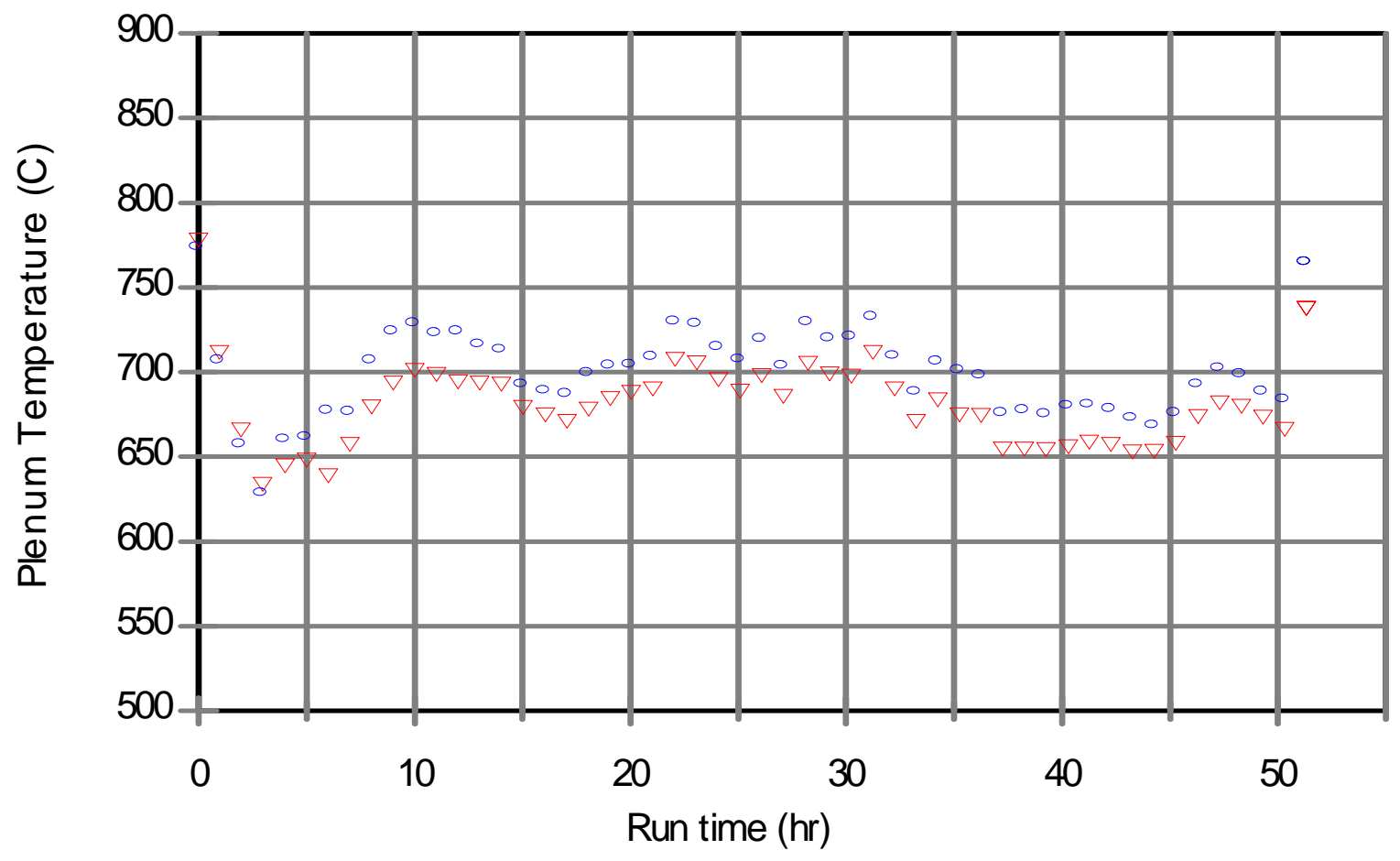

Figure 4.4.c. Plenum temperatures (hourly averages) during SRS SB19 Test 3. 


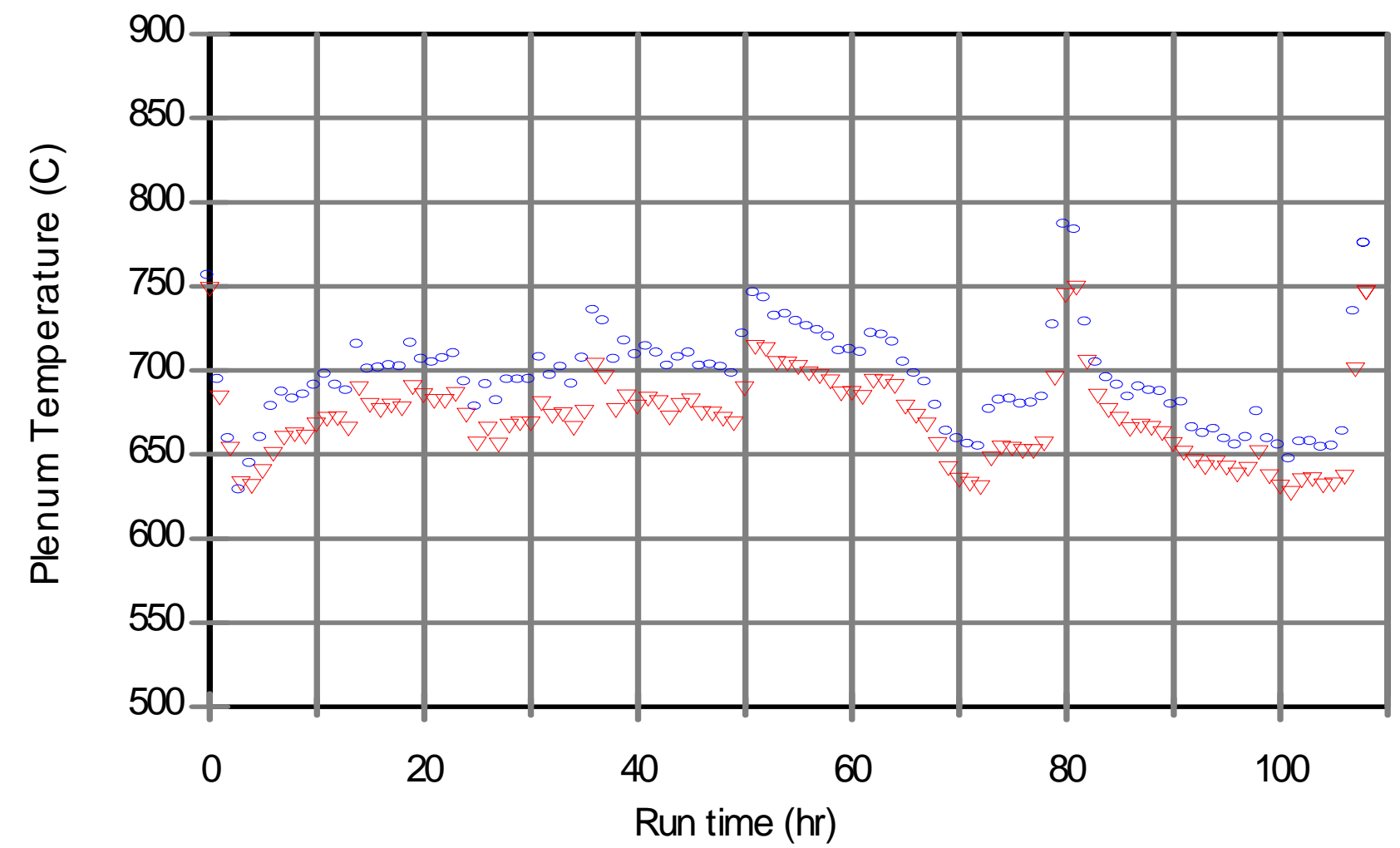

Figure 4.4.d. Plenum temperatures (hourly averages) during SRS SB19 Tests 4 and 5. 


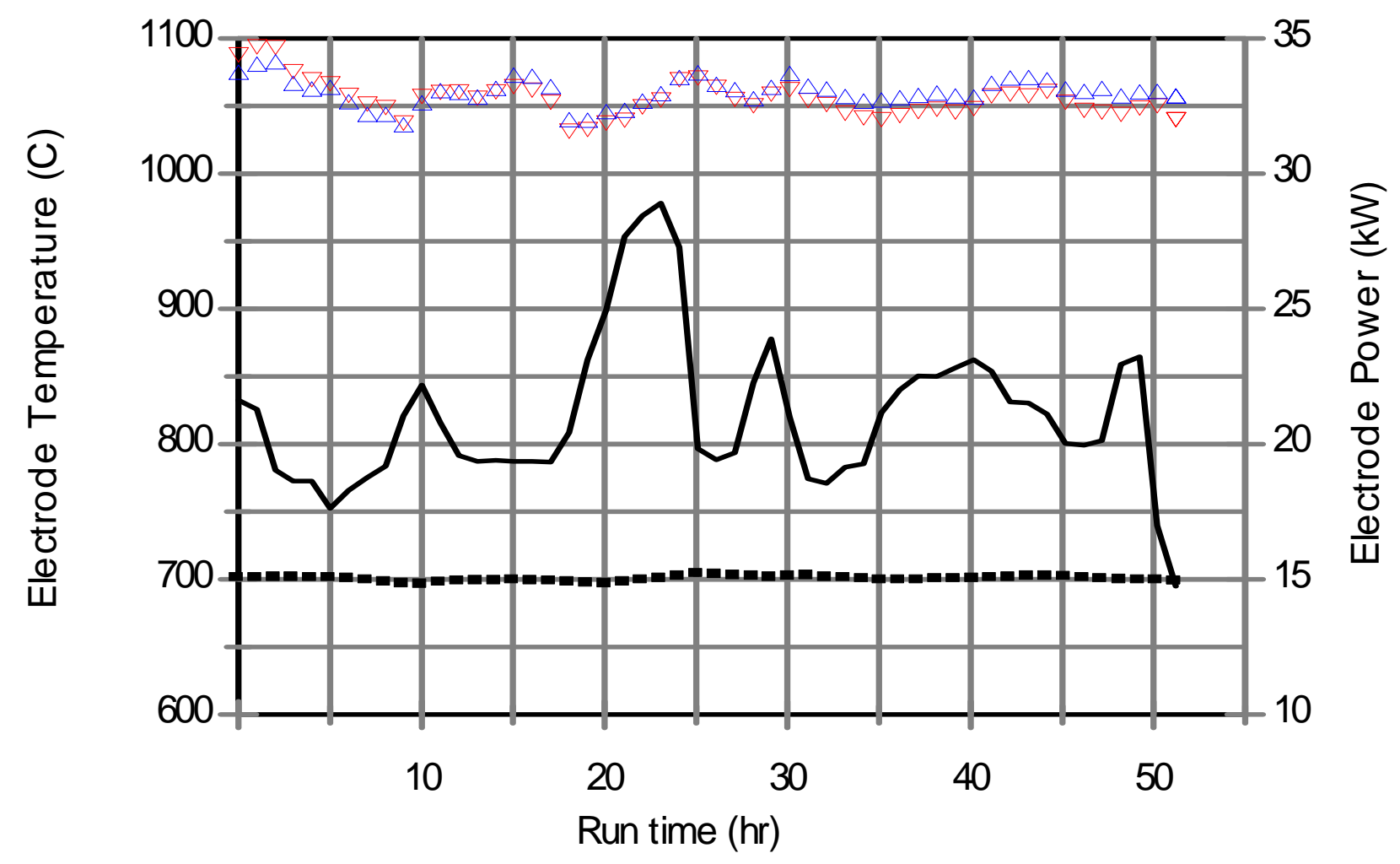

Figure 4.5.a. Electrode temperatures and power (hourly averages) during SRS SB19 Test 1. 

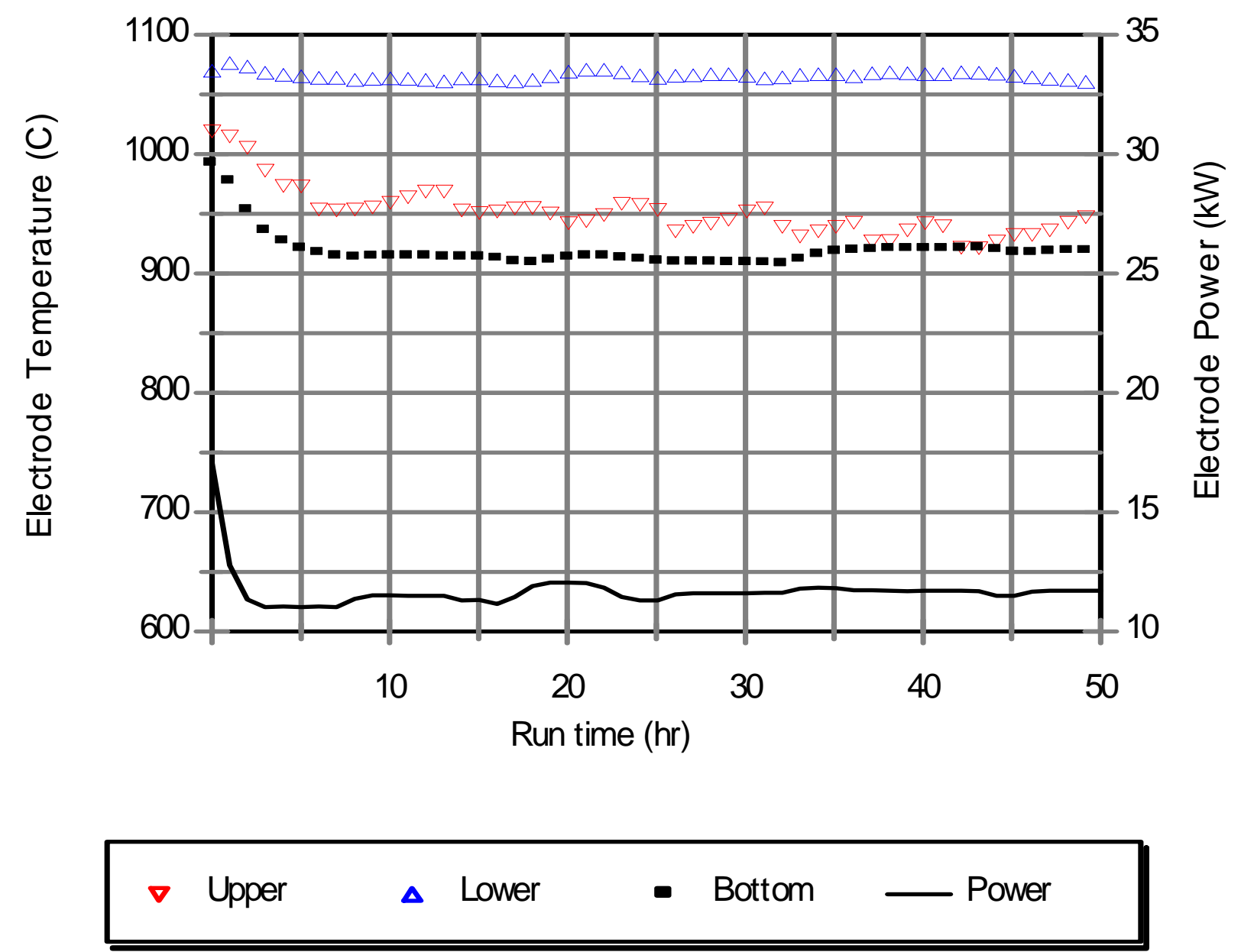

Figure 4.5.b. Electrode temperatures and power (hourly averages) during SRS SB19 Test 2. 

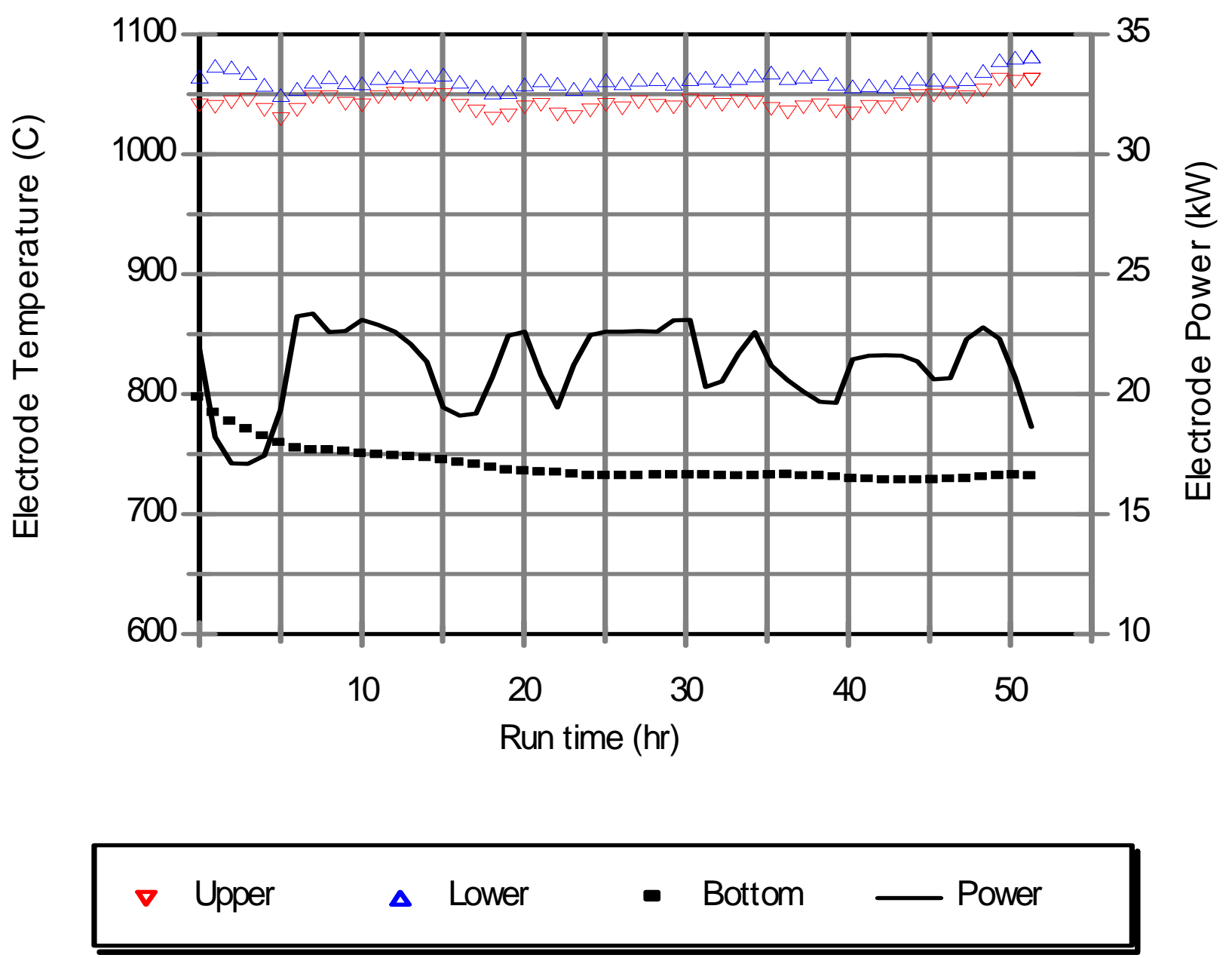

Figure 4.5.c. Electrode temperatures and power (hourly averages) during SRS SB19 Test 3. 

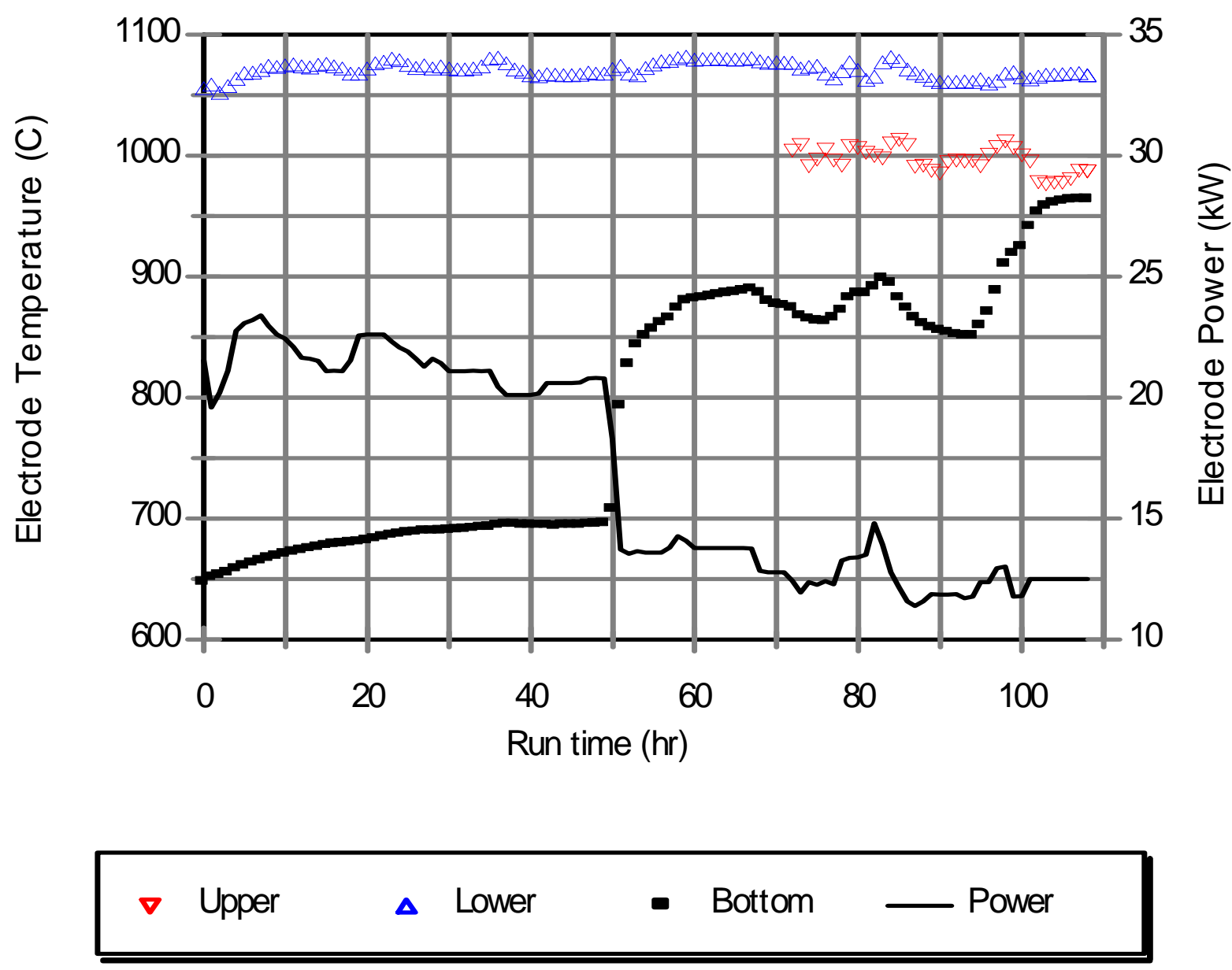

Figure 4.5.d. Electrode temperatures and power (hourly averages) during SRS SB19 Tests 4 and 5. 


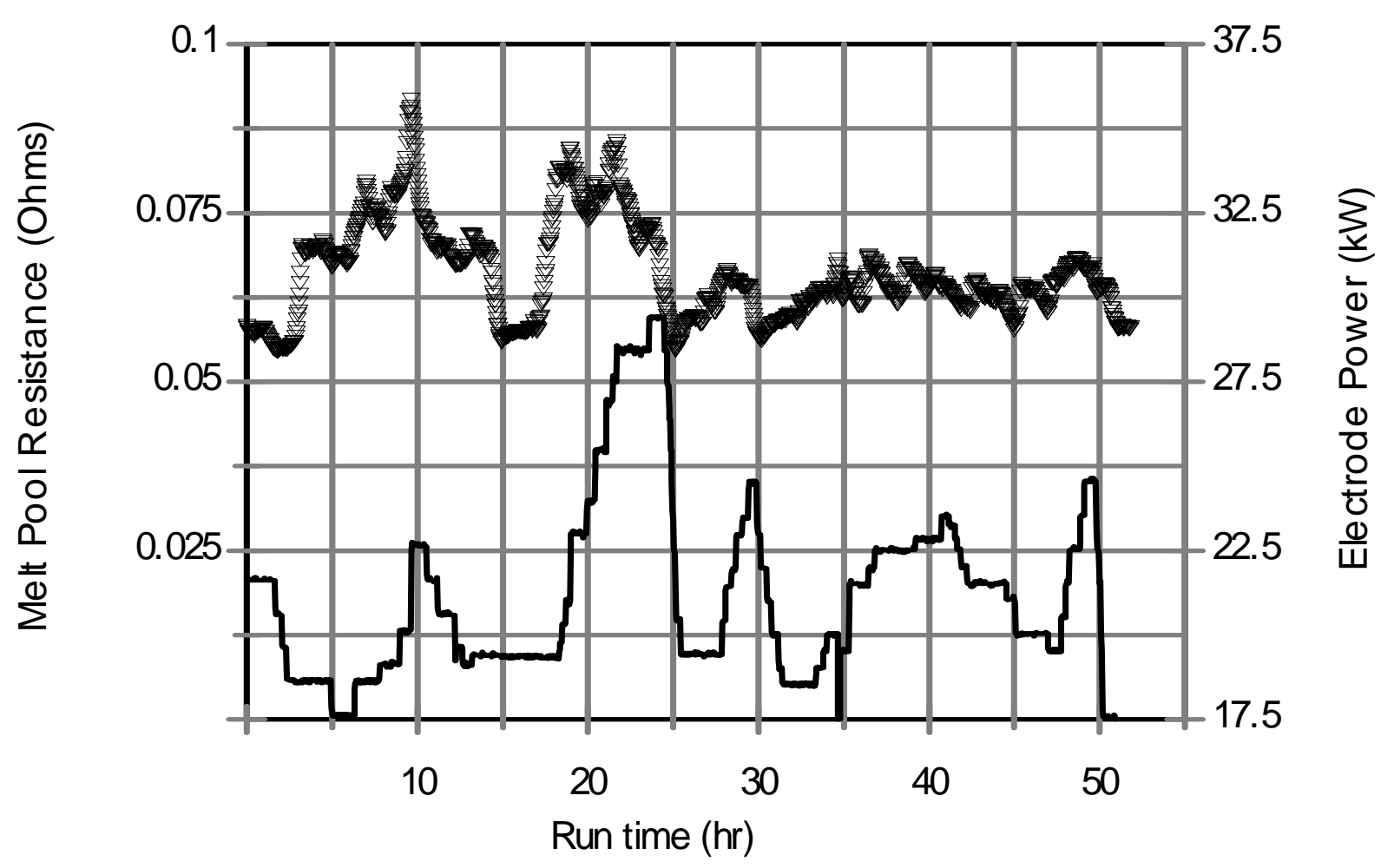

$\nabla$ Resistance Power

Figure 4.6.a. Melt pool resistance and total electrode power during SRS SB19 Test 1. 


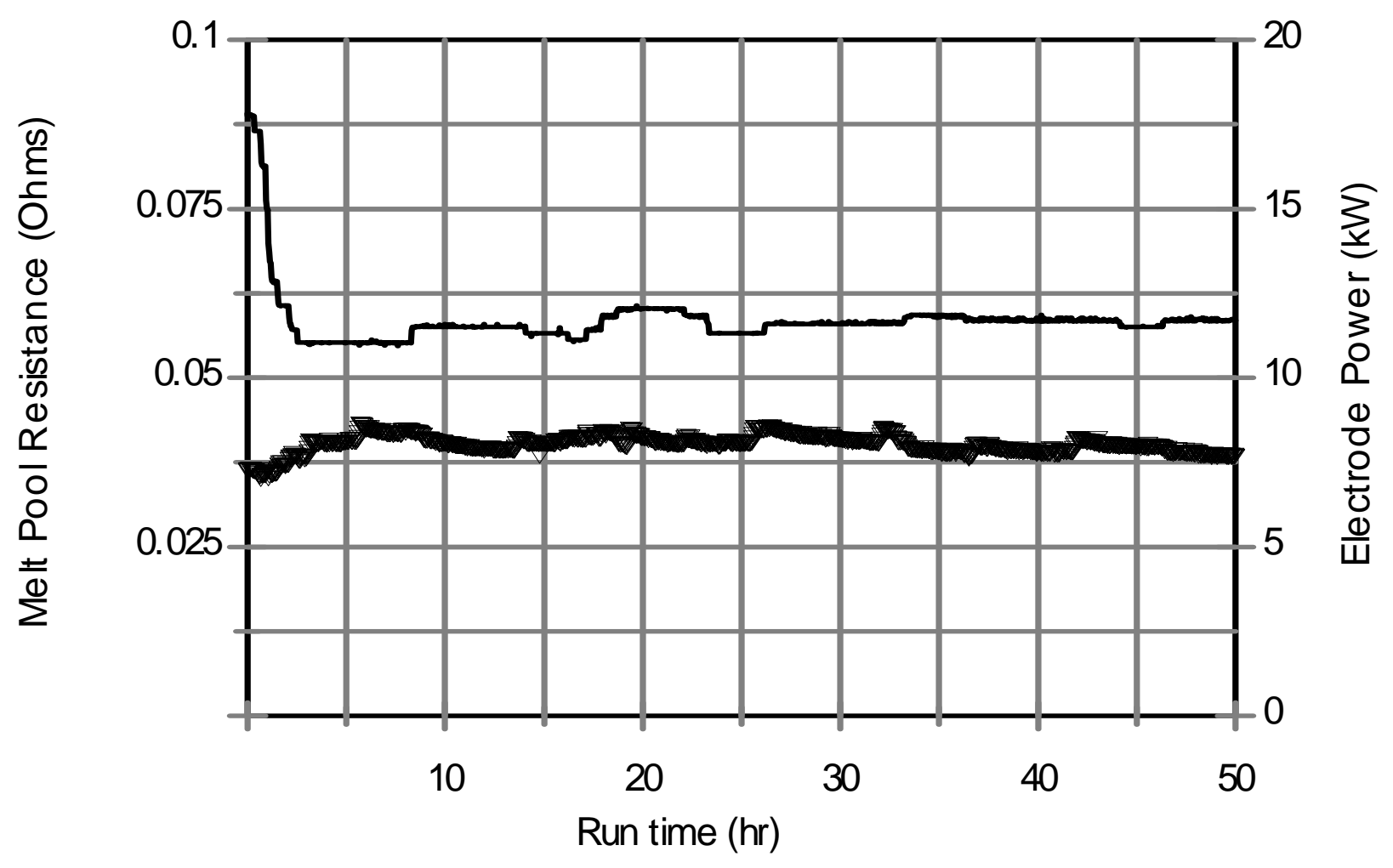

$\nabla$ Resistance $\quad$ Power

Figure 4.6.b. Melt pool resistance and total electrode power during SRS SB19 Test 2. 


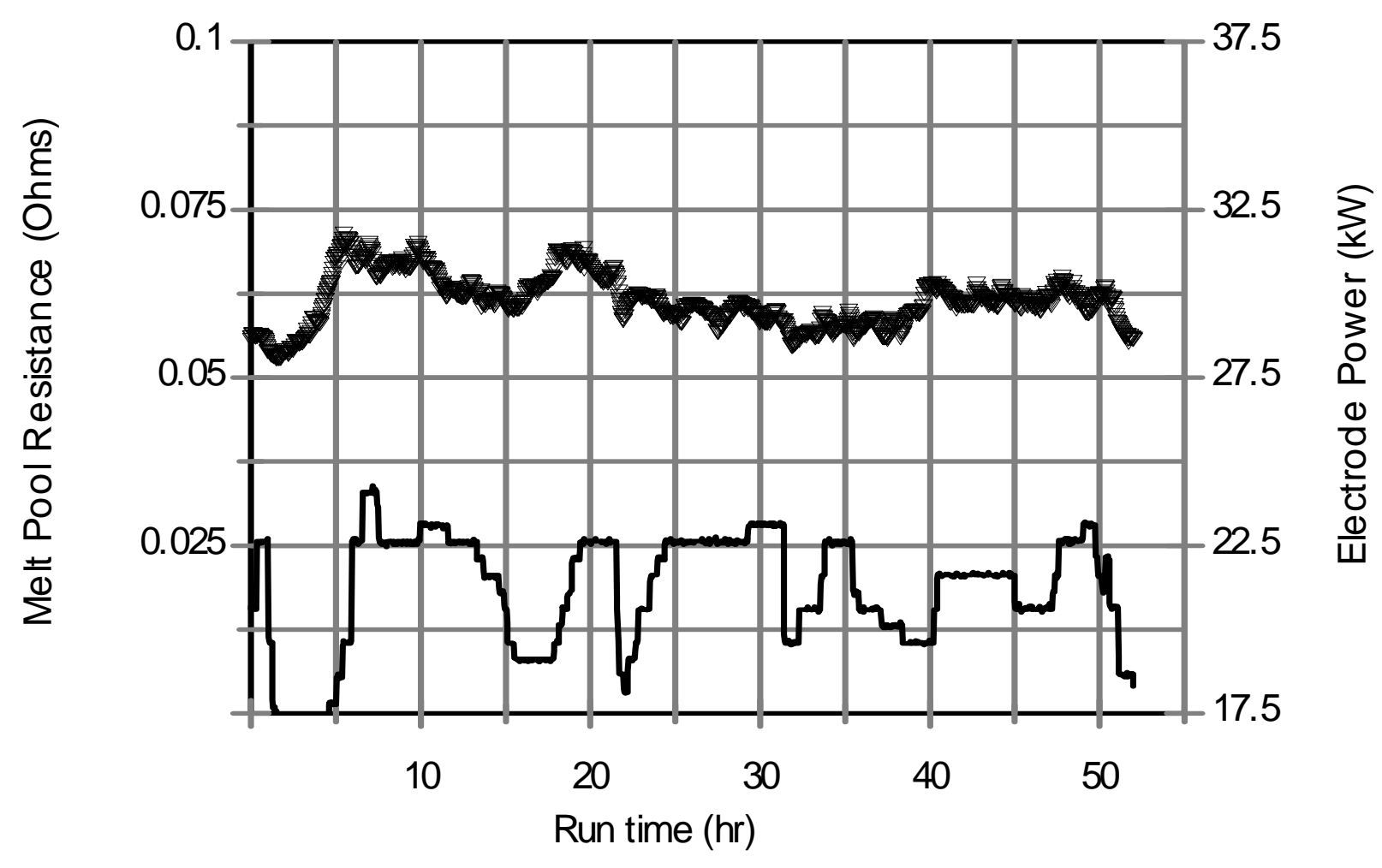

Figure 4.6.c. Melt pool resistance and total electrode power during SRS SB19 Test 3. 


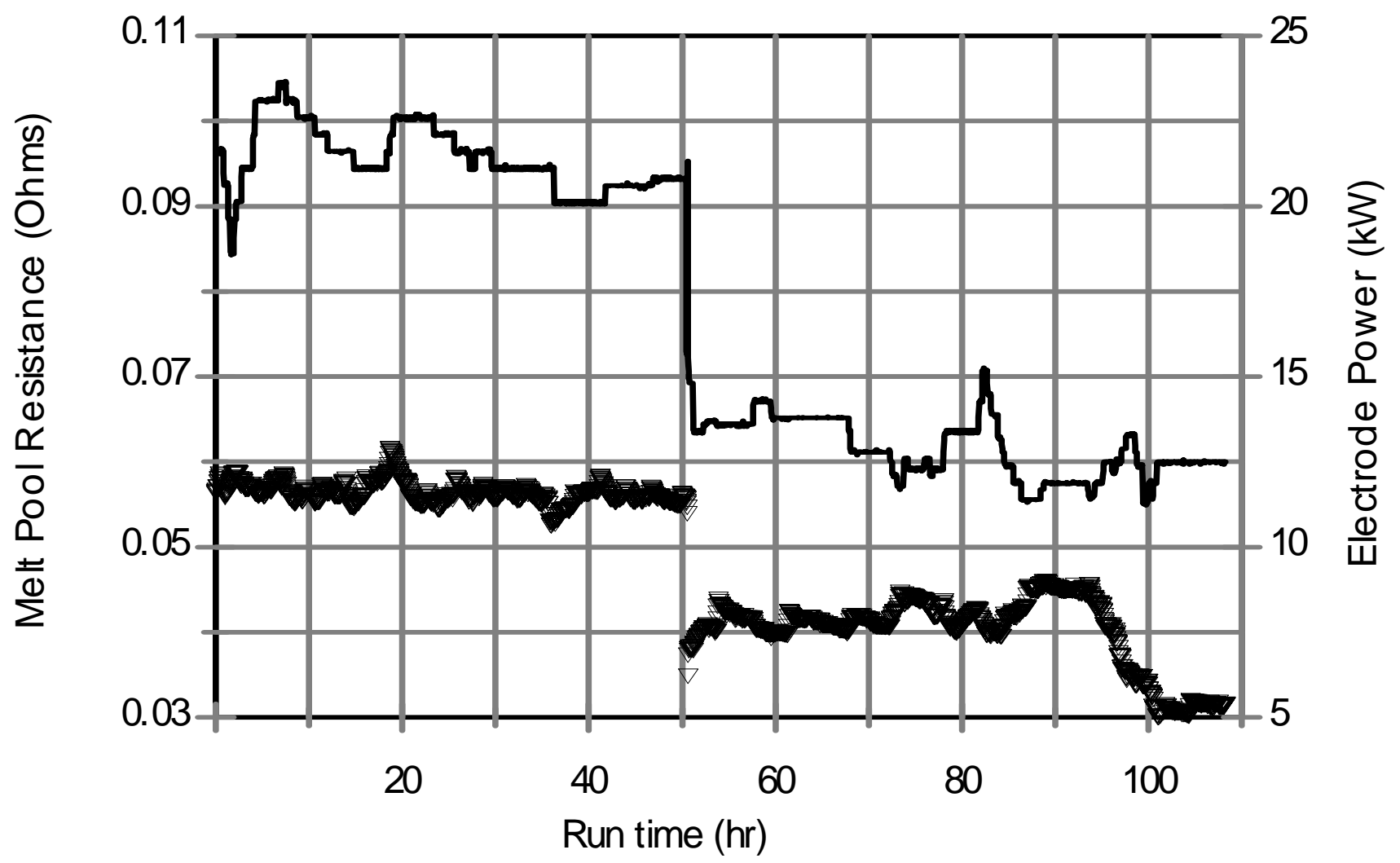

$\boldsymbol{\nabla}$ Resistance $\quad$ Power

Figure 4.6.d. Melt pool resistance and total electrode power during SRS SB19 Tests 4 and 5. 


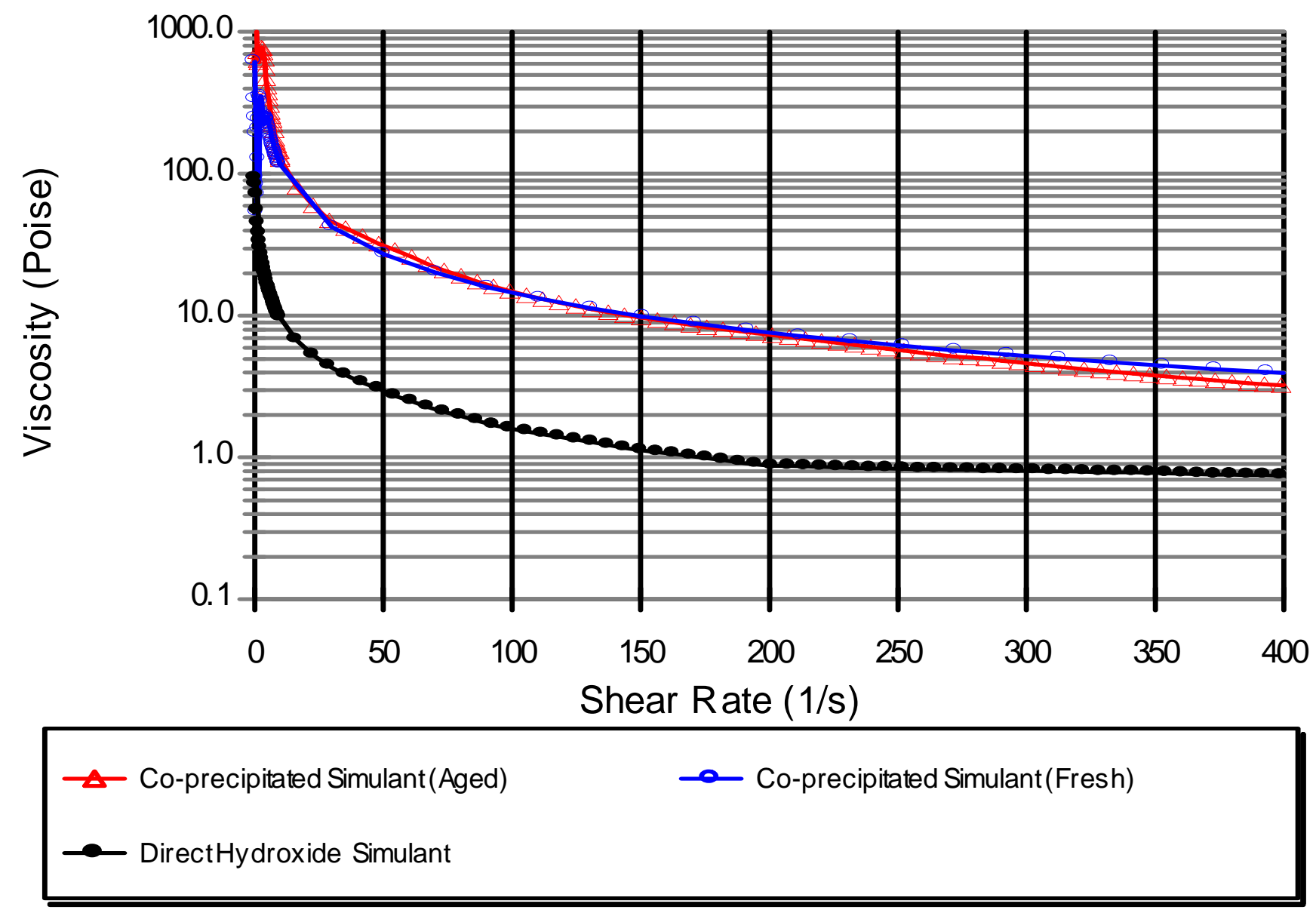

Figure 5.1. Viscosity vs. shear rate of melter feed samples containing waste simulated by different methods. 

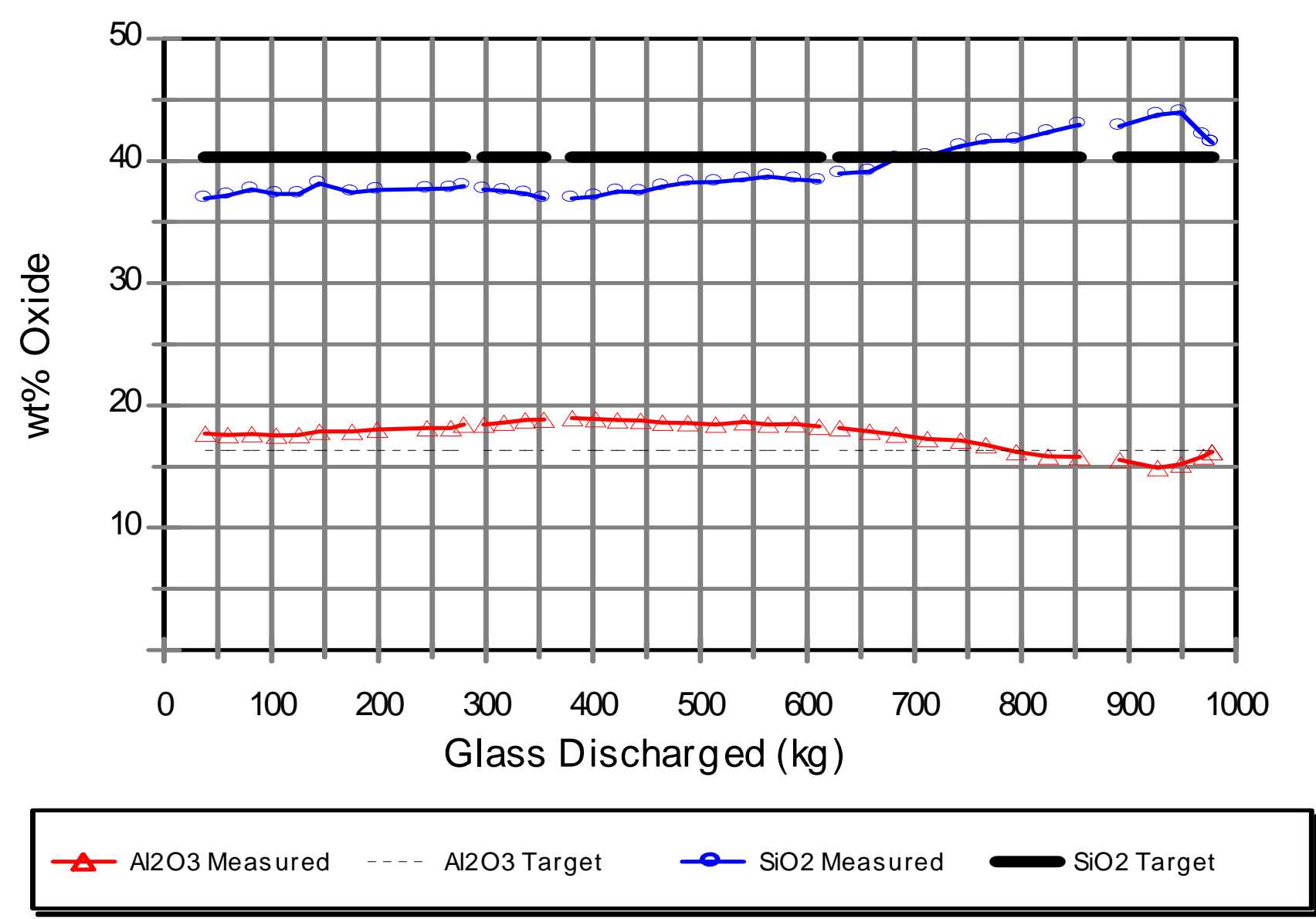

Figure 5.2.a Silicon and aluminum oxide concentrations determined by XRF from glass produced during DM100 SRS SB19 Tests. 

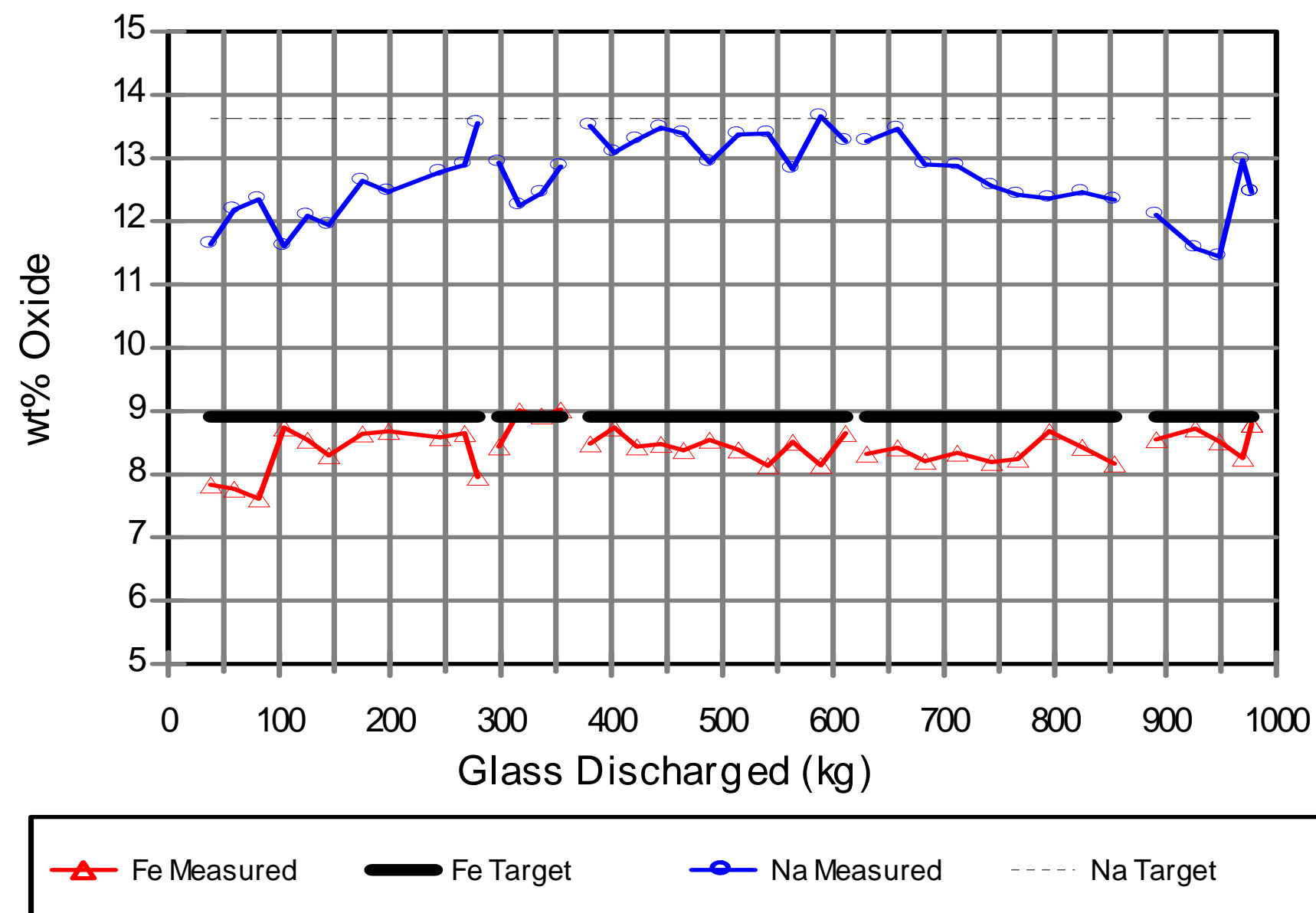

Figure 5.2.b. Iron and sodium oxide concentrations determined by XRF from glass produced during DM100 SRS SB19 Tests. 


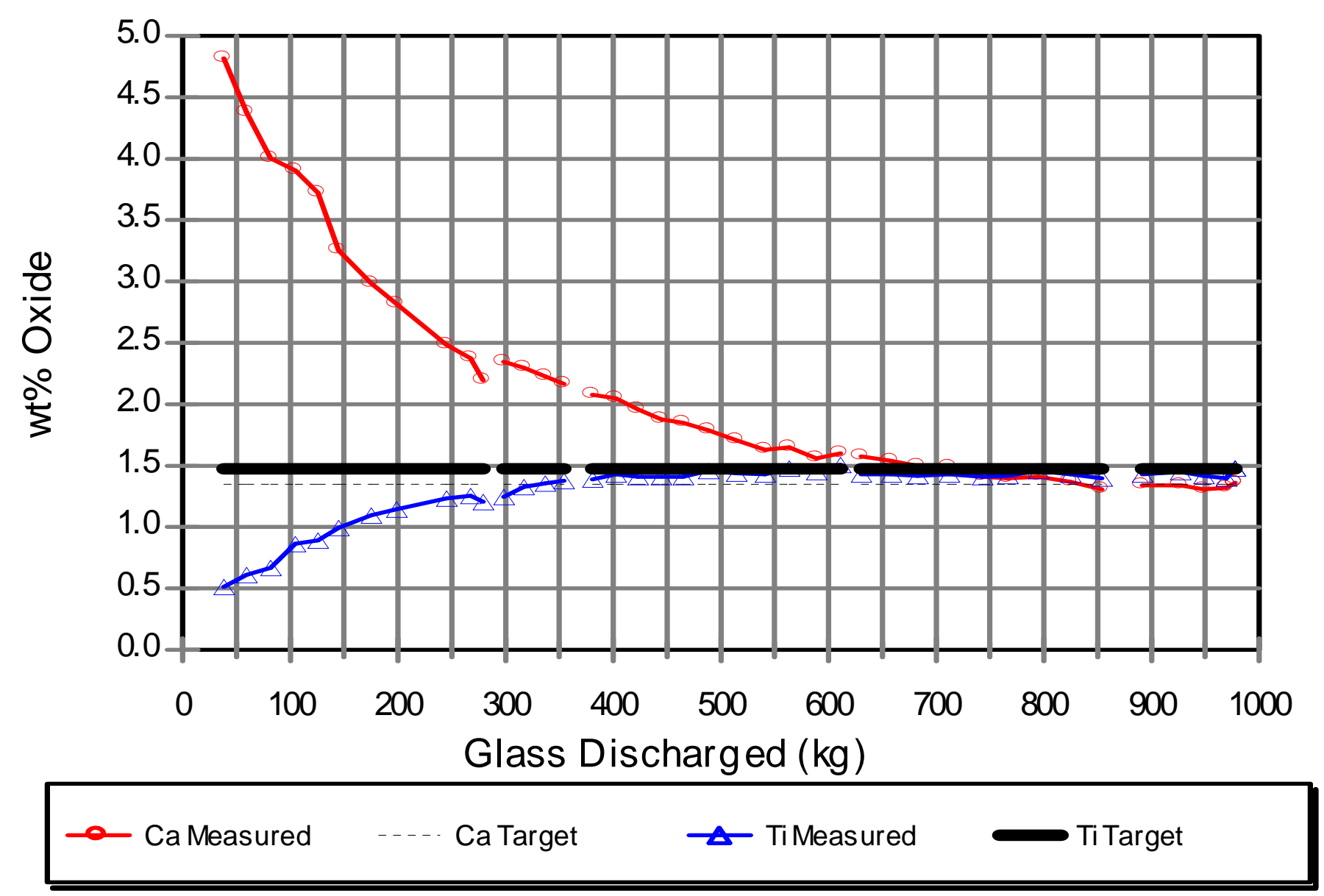

Figure 5.2.c. Calcium and titanium oxide concentrations determined by XRF from glass produced during DM100 SRS SB19 Tests. 


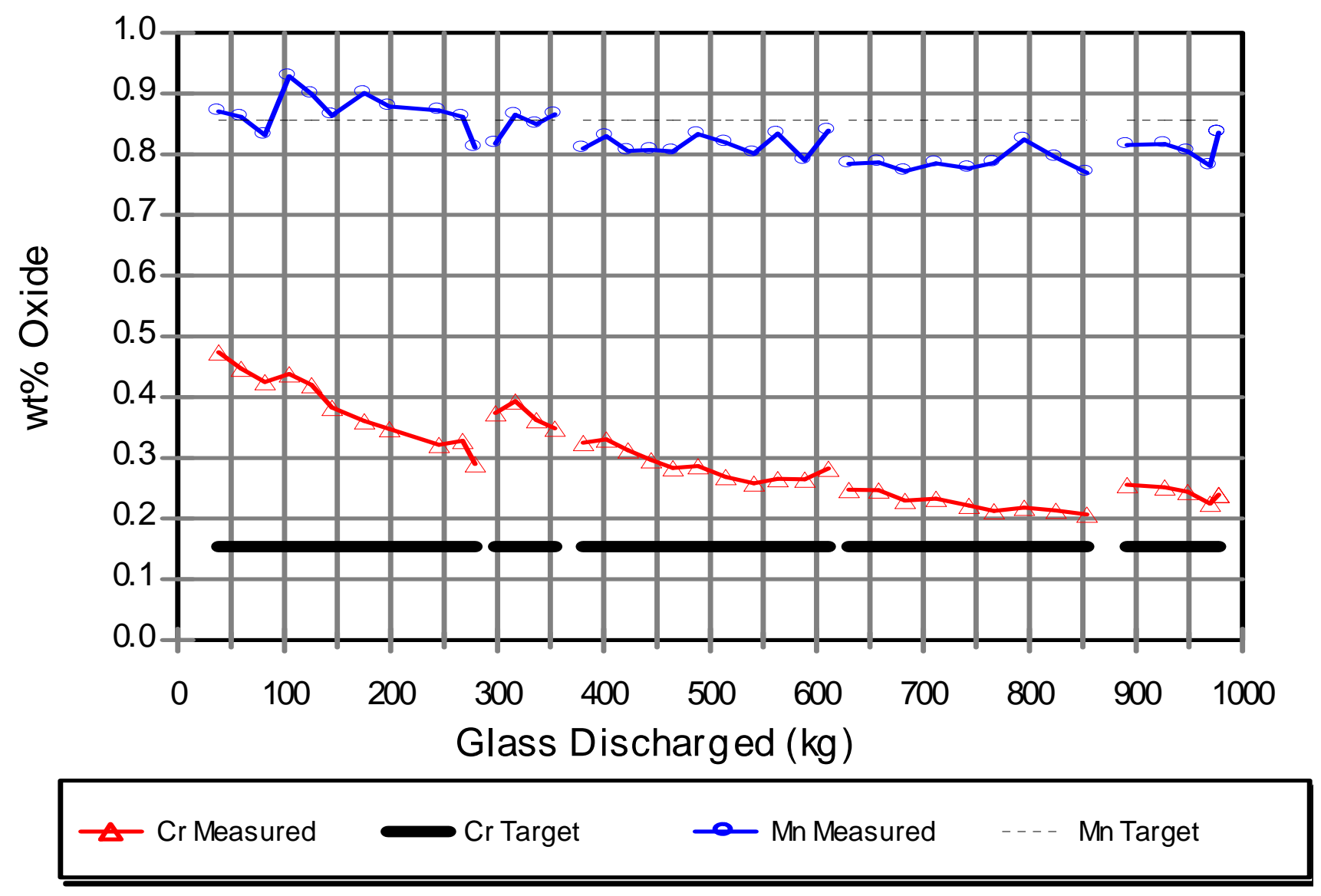

Figure 5.2.d. Chromium and manganese oxide concentrations determined by XRF from glass produced during DM100 SRS SB19 Tests. 

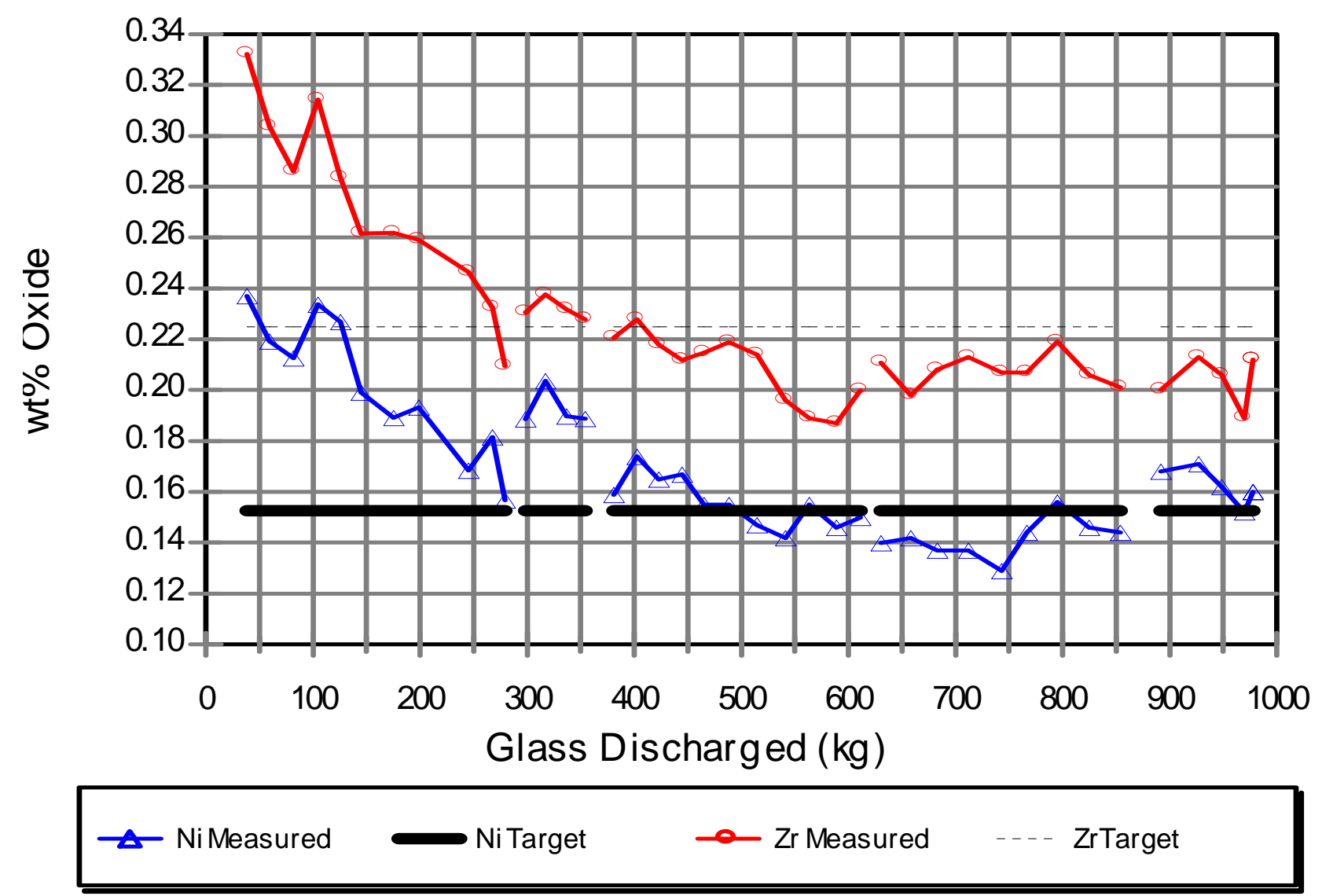

Figure 5.2.e. Nickel and zirconium oxide concentrations determined by XRF from glass produced during DM100 SRS SB19 Tests. 


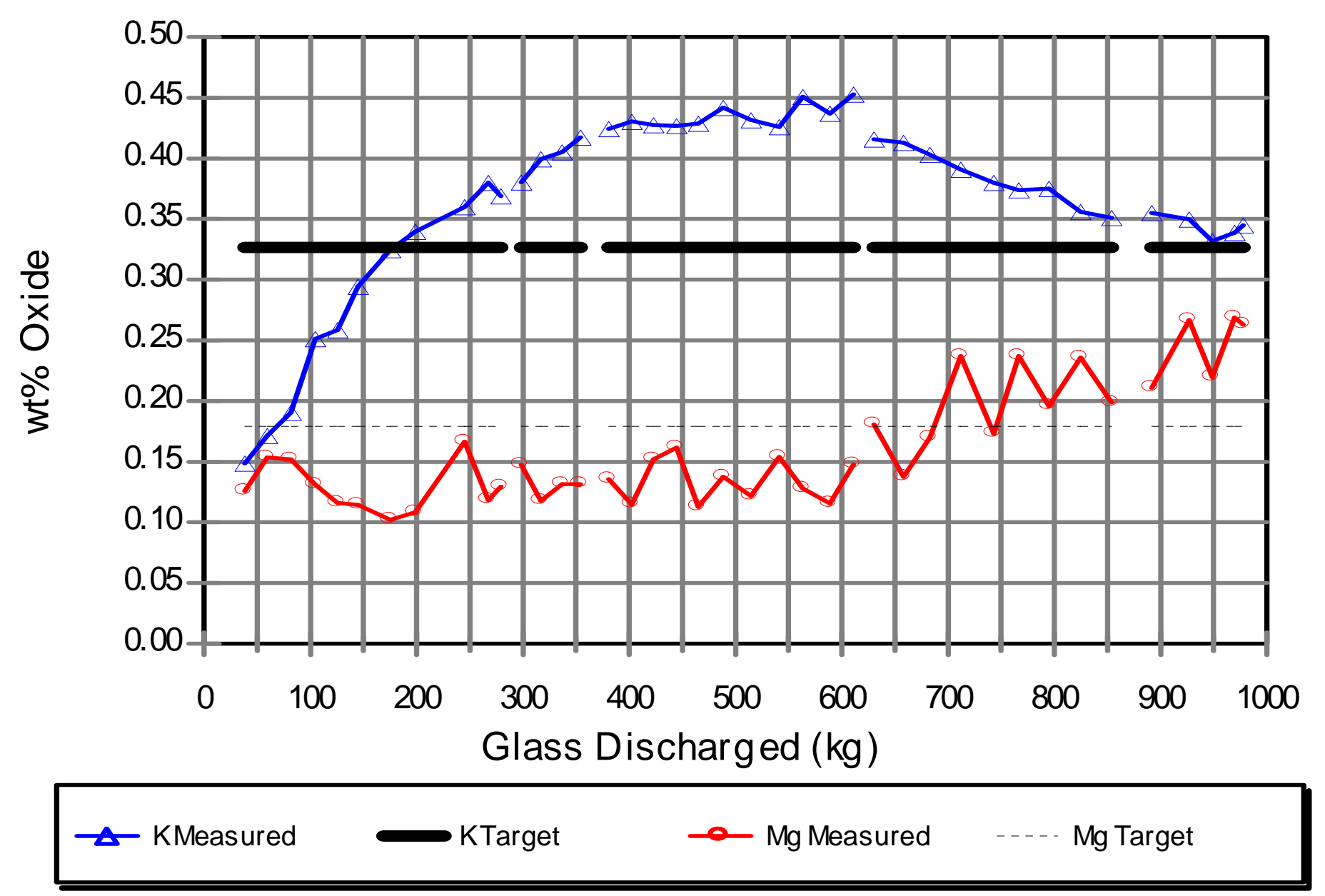

Figure 5.2.f. Potassium and magnesium oxide concentrations determined by XRF from glass produced during DM100 SRS SB19 Tests. 


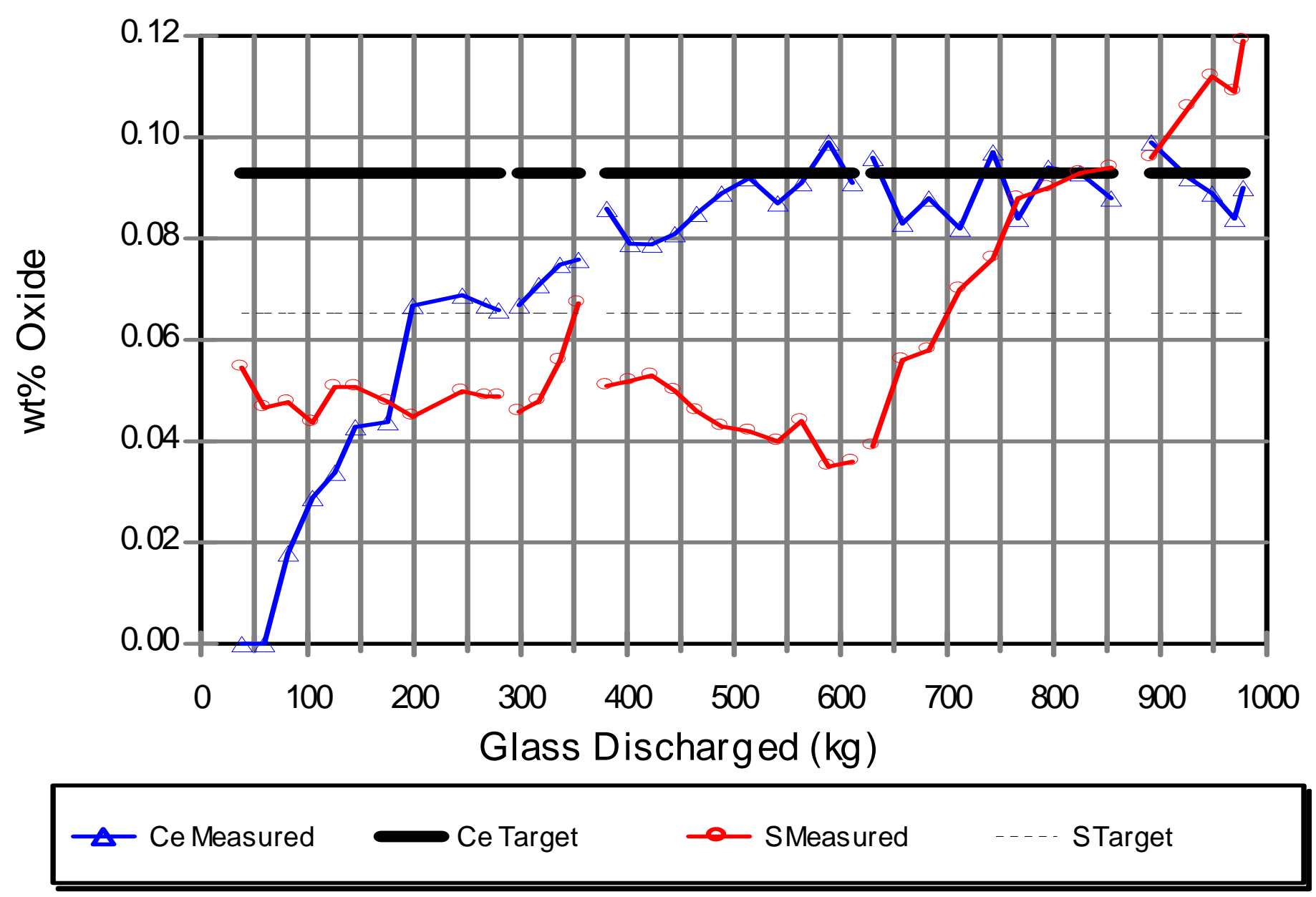

Figure 5.2.g. Cerium and sulfur oxide concentrations determined by XRF from glass produced during DM100 SRS SB19 Tests. 


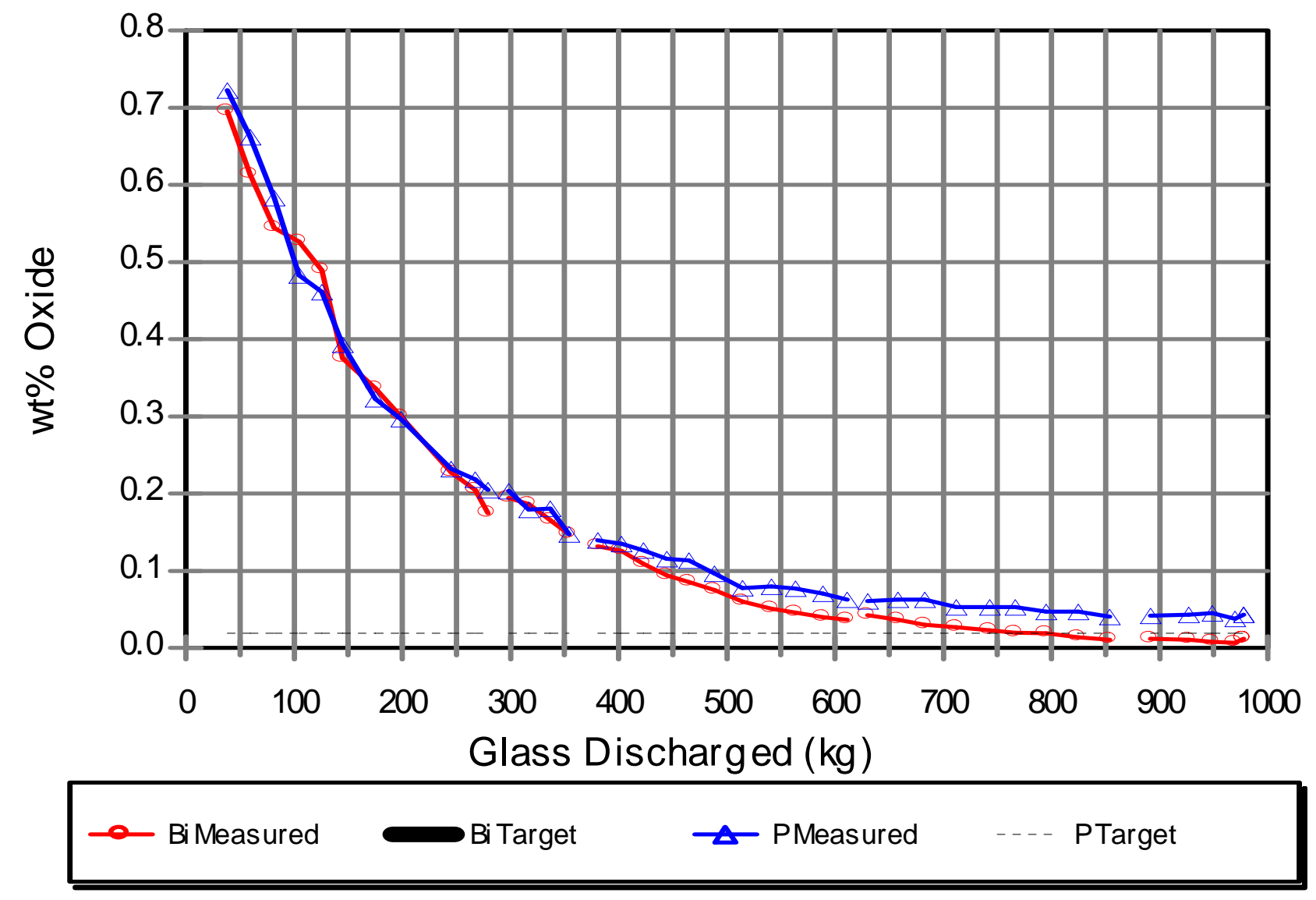

Figure 5.2.h. Bismuth and phosphorus oxide concentrations determined by XRF from glass produced during DM100 SRS SB19 Tests. 


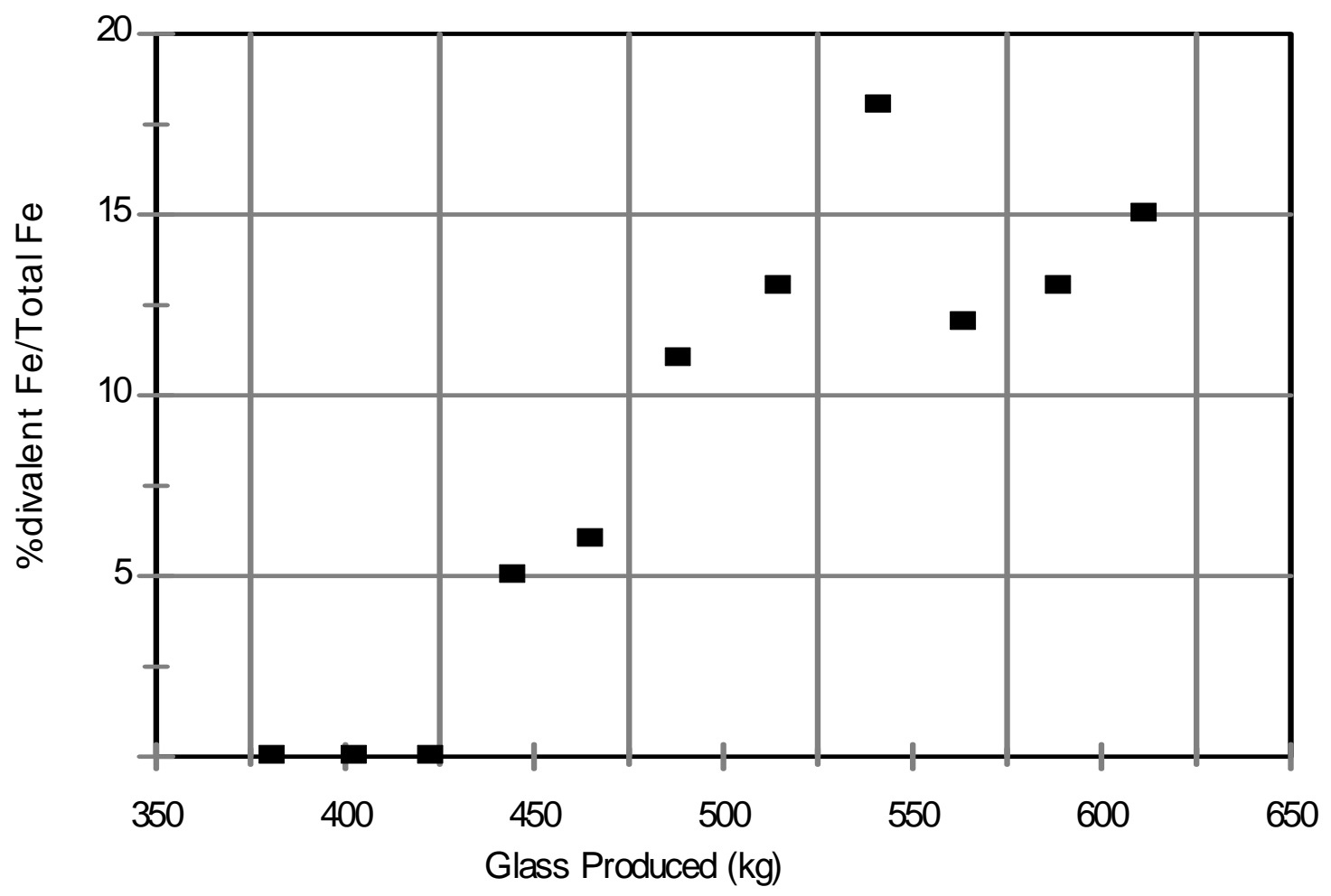

Figure 5.3. Measured glass divalent iron concentrations during DM100 tests with SRS SB19 waste simulant produced by Harrell Industries. Test conducted with argon bubbling. 


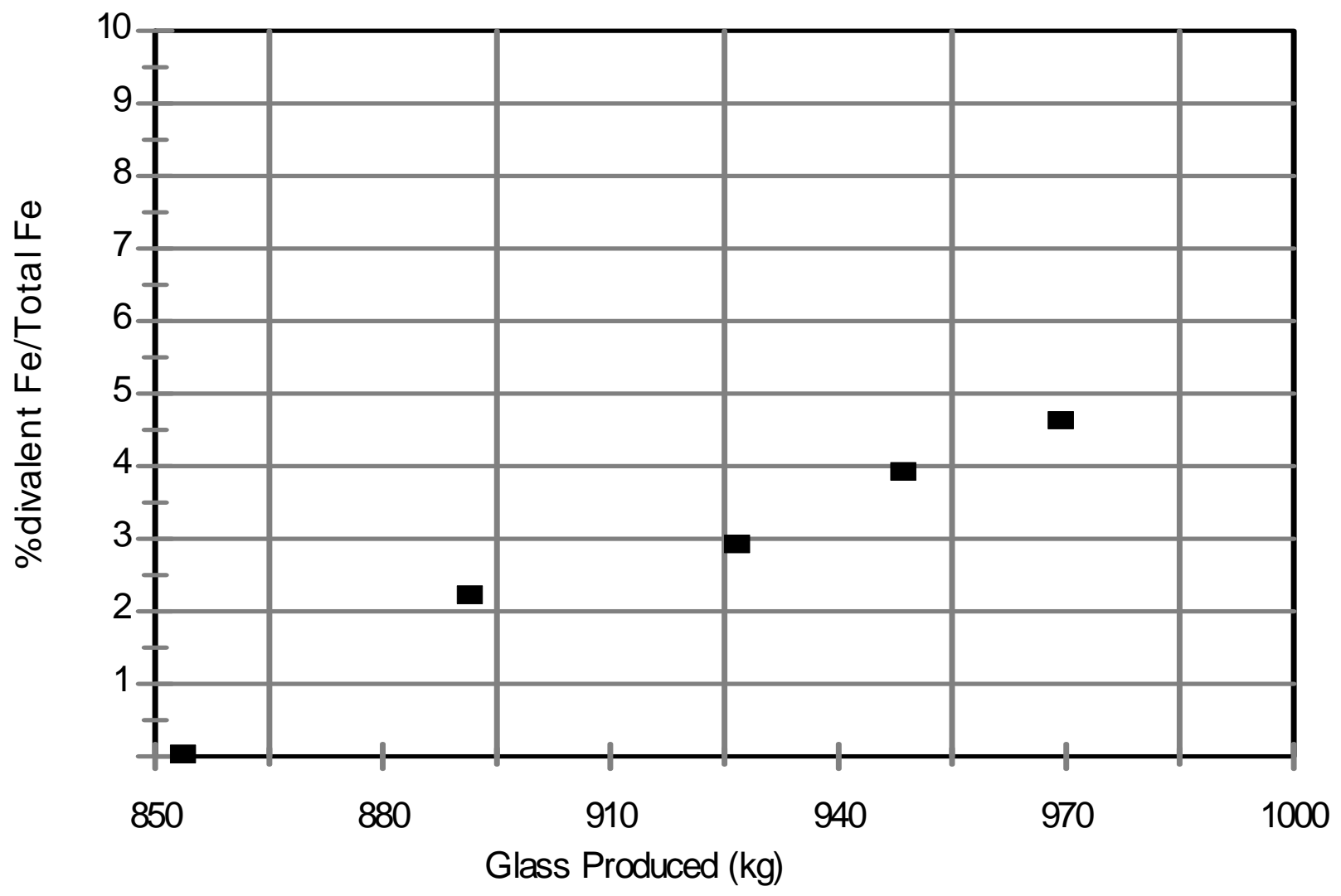

Figure 5.4. Measured glass divalent iron concentrations during DM100 tests with SRS SB19 waste simulant produced by NOAH. Test conducted without bubbling. 